
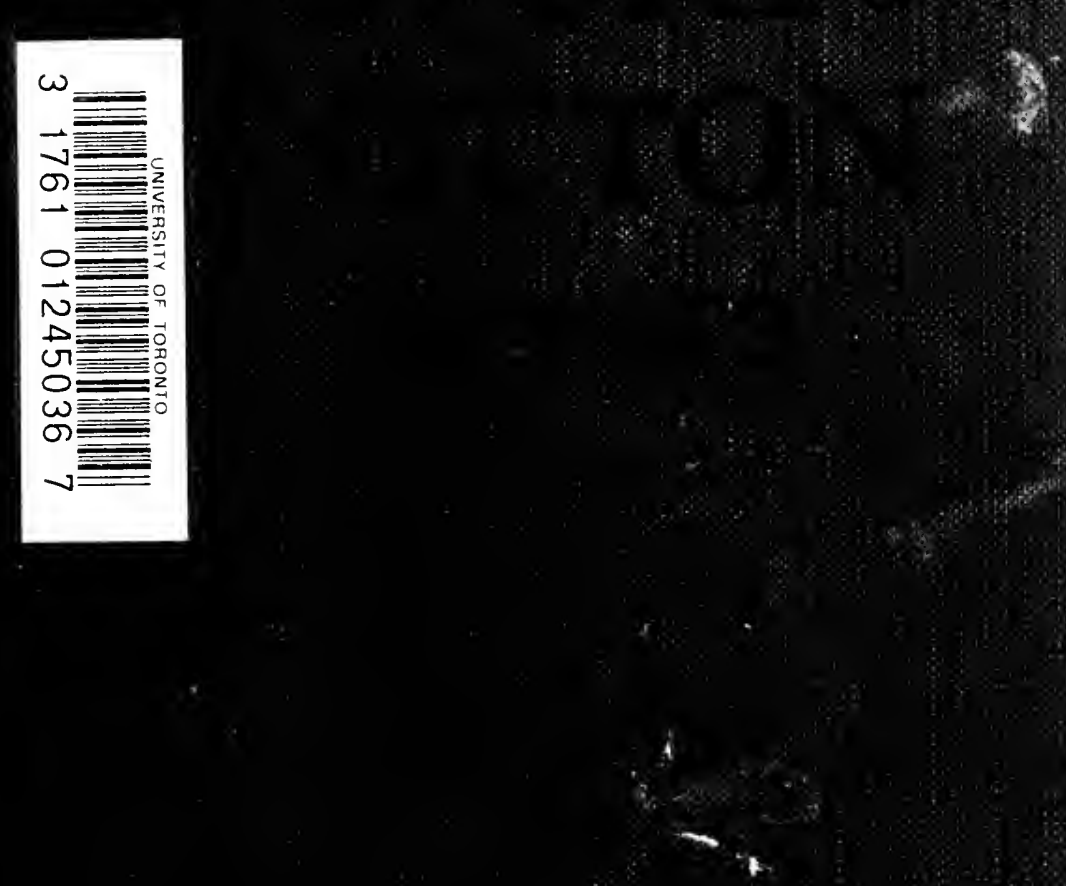
Digitized by the Internet Archive in 2007 with funding from Microsoft Corporation 


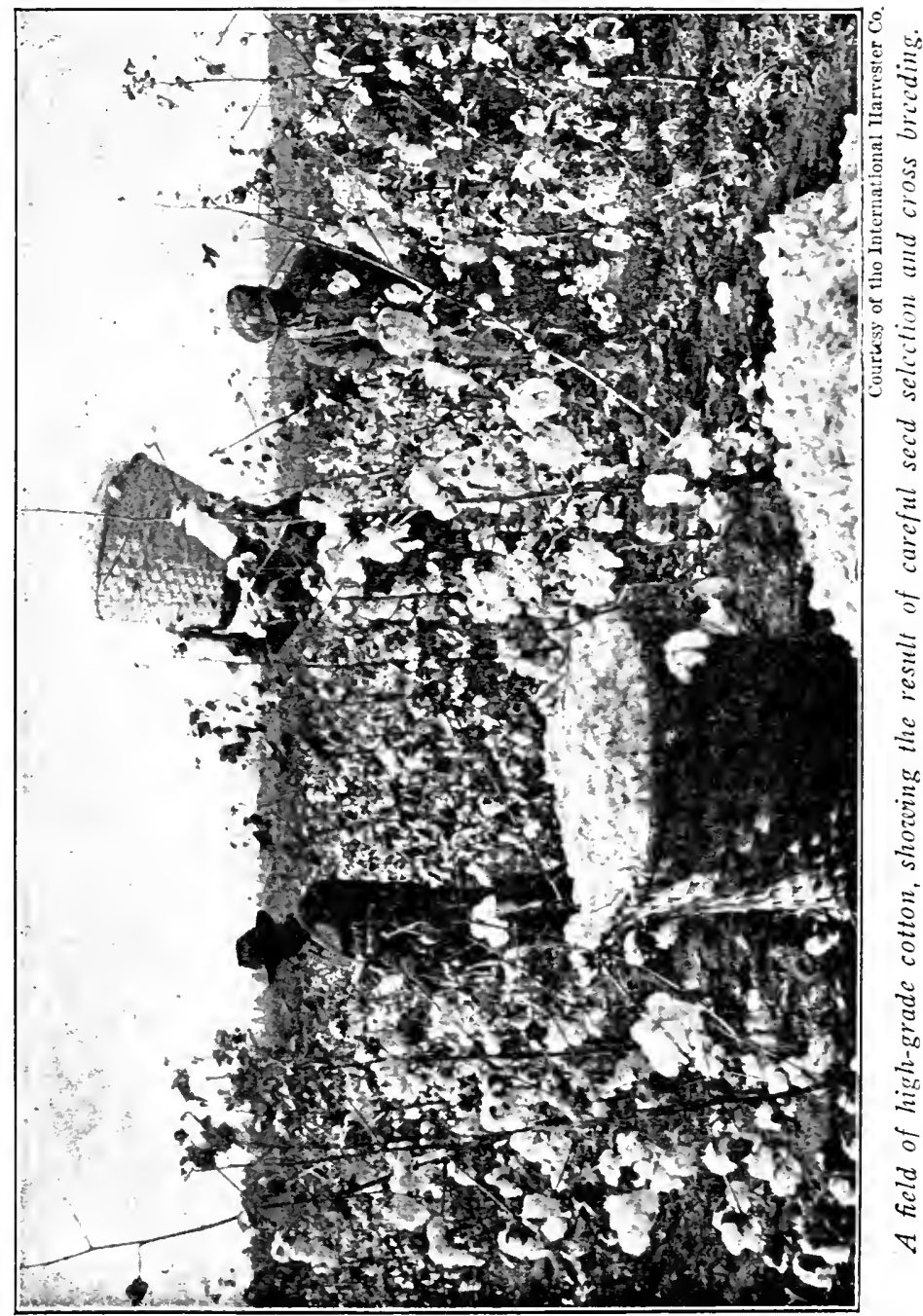




\section{The STORY of COTTON AND THE}

Development of the Cotton States
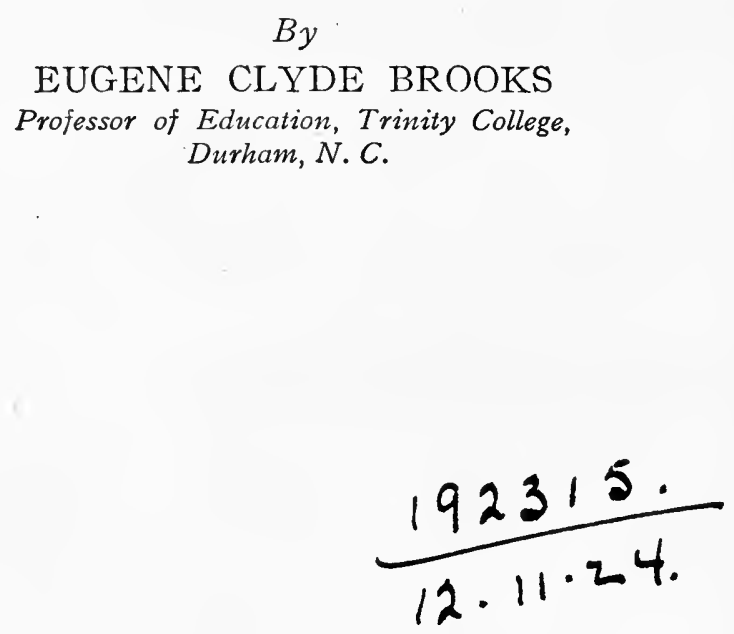

RAND MCNALLY \& COMPANY Chicago New York London 
Copyright, IOII,

By EUGENE C. BROOKS

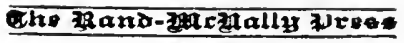

Chicago 


\section{THE PREFACE}

The cotton industry is probably the greatest single industry in the world if the cultivation, manufacture, commerce, and the uses of the cotton products are considered. The influence of the cotton plant on the history of America is especially interesting. The commerce of the Middle Ages, Columbus's discovery of America, the trade between England and her American colonies, the revolution of the colonies, the War of I $8 \mathrm{r} 2$, the building of the nation, the institution of slavery, the tariff question, the extension of the nation beyond the Mississippi, the Civil War, and the rebuilding of the South were all deeply affected by the cotton industry; and the world's commerce for more than a century has been affected largely by it. For nearly a century the industrial life of the South has been either directly or indirectly related to the cotton industry, and this industry controlled for many years the politics of this country and influenced in no small measure the politics of Europe.

Therefore this great economic force has more than ordinary interest for all students of America and especially for students of the South, whose history is affected so vitally by it. Pupils in our public schools have been taught almost exclusively the political history of our country. They have had told to them over and over again the story of political upheavals and military operations, although these crises are probably the results of certain economic forces working in the life of the people. It should be one of the chief aims of the schools, therefore, to acquaint the student with the leading economic forces of his neighborhood, his state, and his country, in order that he may better understand the politics of the country. 
"The Story of Cotton" treats of one of the greatest industries of the world and its relation to the life of the people. As a text-book it may be studied profitably in connection with the history of America. It will naturally find a place, therefore, in the grammar schools or the high schools wherever American history is studied.

In the preparation of this book thanks are due Mr. D. A. Tompkins of Charlotte for a number of illustrations; Dr. W. K. Boyd and Dr. J. J. Wolfe of Trinity College, Durham, North Carolina, for assistance in collecting material; and especially due Dr. W.T. Laprade of Trinity College, Durham, North Carolina, for his review and criticism of the manuscript, and Professor A. H. Merritt for à critical reading of the proof.

EugENE C. BRooks. .

Durham, North Carolina. 


\section{THE TABLE OF CONTENTS}

The Preface $\ldots \ldots \ldots \ldots \ldots \ldots \ldots \ldots \ldots \ldots \ldots$ ii

A List of the Maps............................

CHAPTER I

Clothing and the Value of Cotton................. 1

Food, Clothing, and Shelter-Significance of ClothingWhere the Arts of Living were Very Primitive-Where Skill Excited a World Admiration-Effect of Enlightenment on Ignorance-The Brotherhood of Man-The World's Clothing Material-King Cotton.

\section{CHAPTER II}

How Europe Learned the Value of Cotton............ 20

The First Cotton Country-Where Cotton Grew Wild-Other Countries Cultivated the Wool-growing Tree-How Traders Found Their Way to the Land of Cotton-Venice and Genoa Became Great Markets of Europe-Effects of this Trade on Europe-Venice Triumphs over Genoa-The Trade Routes Clearly Defined -Why Columbus Discovered America-What the Natives Knew of Cotton-The Commercial Center of the World is Changed-How Different People Named Cotton.

\section{CHAPTER III}

Origin of Cotton Culture in the United States.

The Nature of the Cotton Plant-Its Habits in the South - How England Encouraged its Cultivation-Extent of the Cotton Patches-The Difficulty of Removing the SeedHow Settlers Encouraged Manufacturing-How Cotton was Prepared for Spinning-Difficulty in Manufacturing Cotton Goods-What they were Trying to Imitate. 


\section{CHAPTER IV}

Development of Skilled Workmen in America.......... 51

Economic Strength of the Colonies-How the World Had Prospered Economically-Impossibility of an Industrial Monopoly-Impossibility of a Cotton Monopoly-The Hand Loom of Our Grandmothers-The Distaff and the Spindle-The Spinning Wheel-Increasing Interest in Cloth Making-George Eliot's Weaver-Activity in the Colonies-How England Discouraged this Activity-How It Produced a Revolution.

\section{CHAPTER V}

How Skill Created a Demand for Cotton............. 71

How the War Encouraged Manufacturing-Interest in Spinning-How Homemade Goods were EncouragedHow Cotton was Cultivated at the End of the War-The Ancient Gin in Use-Dependence of America upon Europe -The Progress of Labor-The Age of Invention-The Statesman and the Inventor.

\section{CHAPTER VI}

How Cotton Became King of Clothing.

The World is made over-Richard Arkwright-The Spinning Frame-The Spinning Jenny-How this Invention was Received-Another Invention was Needed-The Story of Eli Whitney-His Visit to the Land of Cotton-The Problem was Presented-How the Gin was Made-How the Gin was Received-Its Effect on the South-Yet Another Invention was Needed-The Story of James Watt-How the Steam Engine was Made-Effect of the Steam EngineEffect of these Three Inventions on the World.

\section{CHAPTER VII .}

The Coming of the Factory to America...............109

How the States Tried to Secure the Arkwright Machines -The Efforts of Tench Coxe-Samuel Slater-Samuel Slater's Success-The Complete Factory-The Factory in the South-The Demand for Cotton Increases-Effect of the War of 1812-Why the Factory First Found a Home 
in New England-How the Cotton Industry Affected Labor - How the Cotton Industry Affected the Social Life-How the Cotton Industry Affected Politics-How the Factory Influenced Cotton Cultivation.

\section{CHAPTER VIII}

How Cotton Sectionalized the South....................

Wealth is Due to Overcoming Geographical Limitations - How Economic Changes Forced the South into Cotton Production-How Cotton Production Increased-How the Tariff Affected the Cotton States-How Slavery Affected the Cotton States-The First Great Political Fight

- between the States-The Second Great Fight between the States-The Relation of the Cotton States to Foreign: Countries-How the South Turned to Manufacturing-The Economic Condition of the South-The Third Great Fight between the States.

\section{CHAPTER IX}

Life and Activities in the Ante-Bellum Cotton Kingdom .156 Power Measured by its Influence over Men-The Power of the Southern Plantation-The Master's Domain-The Field Hands-Cotton Picking-The Cotton Gin-The Wagon Drivers-The Steward-The Cobblers-Carpenters, Wheelwrights, and Blacksmiths-Other Activities of the Slaves-The Duties of the Mistress of the Plantation-Life and Comfort of the Slaves-Relation of Master's Children to the Slaves-Attachment of Master and Servant-Attending Churches-Some of the Evils of the Plantation System -A New Civilization Hostile to Civilization of the South.

\section{CHAPTER X}

The Fall of the Cotton Kingdom.

A Recapitulation-The Cotton States Set up an Independent Government-The New Constitution-Would there be War?-The South Relied on Cotton for Revenue-The Cotton Famine-A Cotton Famine the Hope of the South -The Trade Routes to the South Cut Off-Old Trade Routes to India Reopened-The Fall of the Cotton King. dom-The Effect of the Fall. 


\section{CHAPTER XI}

Building a New Civilization in the Cotton Kingdom......198

Economic Adjustment during the War-A New Social Adjustment after the War-The Break-up of the Plantations-The Era of Small Farms Begins-Unsettled Labor Conditions-The Rise of the Merchant Class-The Dependence of the World upon the South-The Problem of the South-What Nature has Done for the South-What has Man Done with These Gifts?-The New Empire of Business-The Variety of Manufacturing in the SouthHow Business moved to the Piedmont Sections-Machine Labor $v ' s$. Ignorant Hand Labor-The Beginning of a New . Plantation System.

\section{CHAPTER XII}

Unskilled Labor Gives Way to Improved Machinery. ...223

Why Improved Tools and Machinery were not Used before the War-The Demand for Labor-saving Machines -Evolution of the Plow-The Cotton Planter-Improvements in the Gin-Modern Method of Baling Cotton-Better Transportation Facilities-Good Roads-Another Invention is Needed-The Cotton Picker.

\section{CHAPTER XIII}

Cotton Manufacturing

Invention and the Arts of Life-Why England became the Center of Cotton Manufacturing-How the Factory was Developed-How the Factory Developed in America-The Beginnings of Cotton Manufacture in the South-The Development of the Factory in the South-The Cotton Manufacturing Industry-The South's Relation to the World-The American Factory and the European Factory Compared-Relative Value of Goods Manufactured in the South-How a Bale of Cotton is Treated when it Reaches the Factory-A New Problem in Education-Relative Importance of the Cotton Fiber-The Commercial Importance of Cotton.

\section{CHAPTER XIV}

Agriculture Becomes a Science................280

The Mysteries of Mother Earth-Agriculture a Sacred 
Obligation-Relation of Man to the Soil-How Knowledge of the Soil has Increased-Why America was Backward -Interest in Agricultural Education-Why the South was more Backward-A Serious Problem-Relation of Cotton Production to the Acreage-The Per Cent of Increase or Decrease in Production-Production by States-Character of the Land-Varieties of Soil.

\section{CHAPTER XV}

The Cultivation of the Soil.

The Beginning of Soil Study-Soil the Home of Plants - How Nature Teaches Man-The Plant's Need of FoodHow Food is Secured-How the Plant Draws Food from the Soil-How Plants Digest Food-Habits of the Cotton Plant-Increasing the Food Supply-Commercial Fertilizers -Controlling the Moisture-The Natural Enemies of the Cotton Plant-The Boll Weevil.

\section{CHAPTER XVI}

Different Varieties of Cotton

Varieties of Cotton-What Gives Value to Cotton-Principal Varieties of Cotton-Sea-island Cotton--Egyptian Cotton-Peruvian Cotton-The Tree Cotton in MexicoCotton in India-Upland Cotton-How Different Varieties are Reproduced-Value of Seed Selection-How Seed are Selected-Cross Breeding to Improve the Variety-Cotton of the South in Relation to the World's Supply.

\section{CHAPTER XVII}

\section{The By-Products of Cotton}

Result of Harmony between Man and Nature-How Ignorant Man Considered the Cotton Seed-The First Uses made of Cotton Seed-Products of the Cotton Seed: Linters-The Hulls-Cottonseed Meal-Cottonseed OilGrowth of the Cottonsecd-oil Industry-Commercial Value of the Cotton Seed-Why the Cottonseed-oil Industry is Confined to the South-Other By-products of the Cotton Plant. 


\section{A LIST OF THE MAPS}

A map showing the civilized world immediately before the time of Columbus ........................

The great markets of medieval Europe ............ 30

Ancient and medieval trade routes............... 33

The vast territory acquired by the United States through the Louisiana Purchase ...................... I39

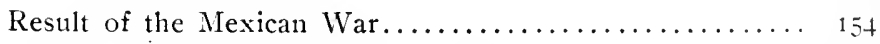

The cotton kingdom, I850, and the limit of the cotton belt. I 162

The yield of cotton per square mile in the cotton kingdom,

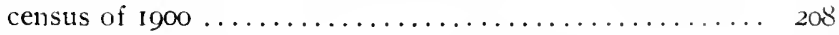

The leading trade centers in the South in $1850 \ldots \ldots \ldots . . \ldots 218$

The leading trade centers in the South in rgro. showing how business moved to the Piedmont................. 219

Map showing area infested by the boll weevil in I9I2 and during various preceding years $\ldots \ldots \ldots \ldots \ldots \ldots \ldots, 327$

Where sea-island cotton is grown .............. 332 



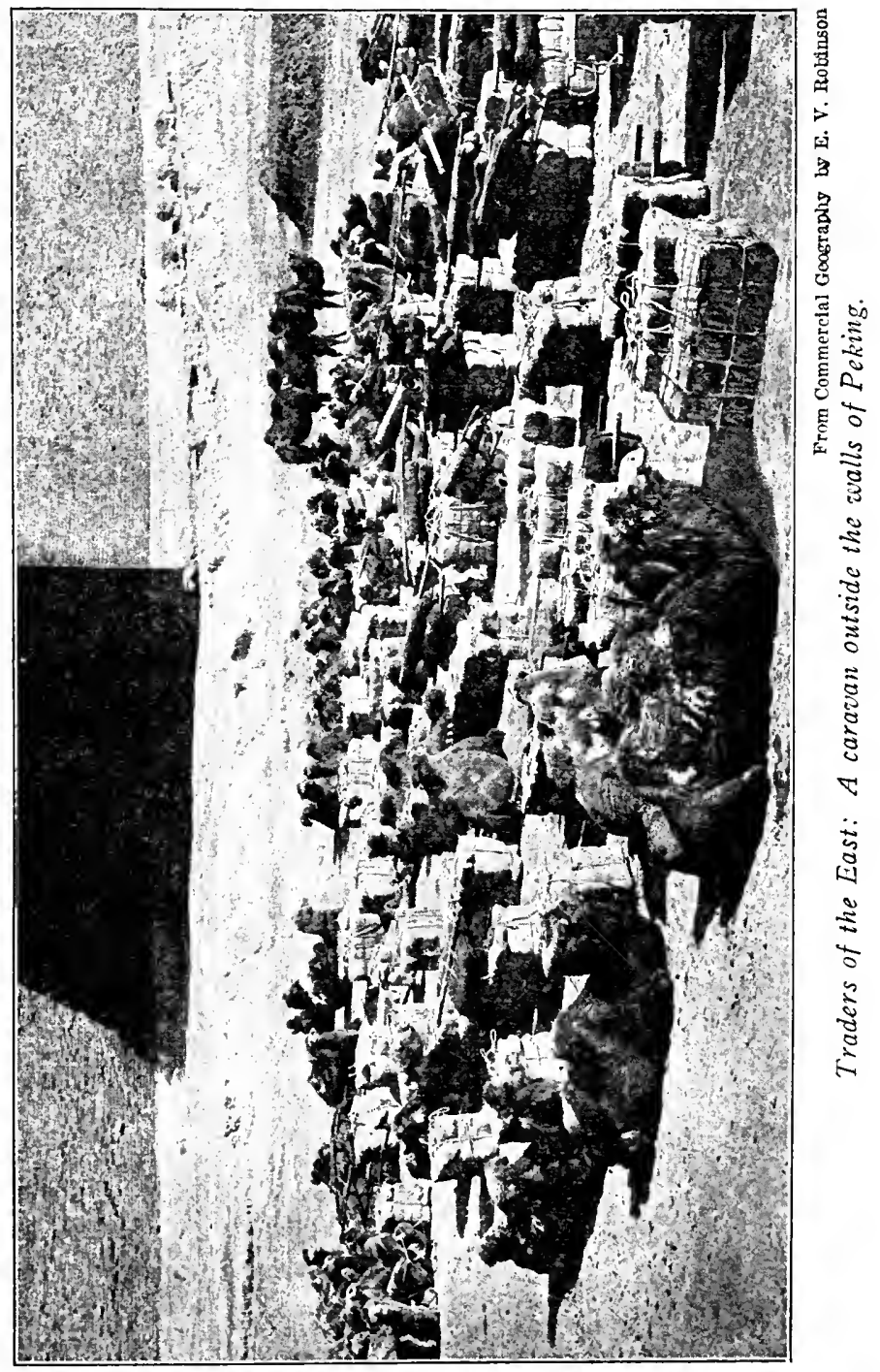




\section{THE STORY OF COTTON AND \\ THE DEVELOPMENT OF THE COTTON STATES}

CHAPTER I

Clothing and the Value of Cotton

Food, Clothing, and Shelter. Three things are essential to the welfare of mankind: food, clothing, and shelter. So closely related are they that if one is coarse, rough, or insufficient, the other two, as a rule, will be likewise. The occupations of people, the governments of men, the commerce of the world, the destiny of nations, all are affected when limitations are placed on either of these three essentials. It matters not whether we study the most ignorant people of the jungles of Africa, whose instincts are but little higher than those of the beasts that seek to devour them, or the most intellectual people of the world, surrounded by all the luxuries that the ingenuity of the most artistic and resourceful minds can procure, food, clothing, and shelter are the objects most earnestly sought; and the pursuit of them controls in a large 
measure the spirits of men. The right to labor, to secure food adequate to the needs and demands of the body, and clothing and shelter sufficient for the comfort and satisfaction of the body, is the underlying principle at the basis of the world's politics. Add to this, freedom of religious thought, which is seriously modified by the struggle for food, clothing, and shelter, and we have the sum total of the rights cherished by modern men. How best to guarantee these rights to all people under all circumstances is the question most widely discussed in parliaments, congresses, and all popular assemblies, both religious and secular.

Significance of Clothing. It is our purpose here to consider in the main only one of these essentials.

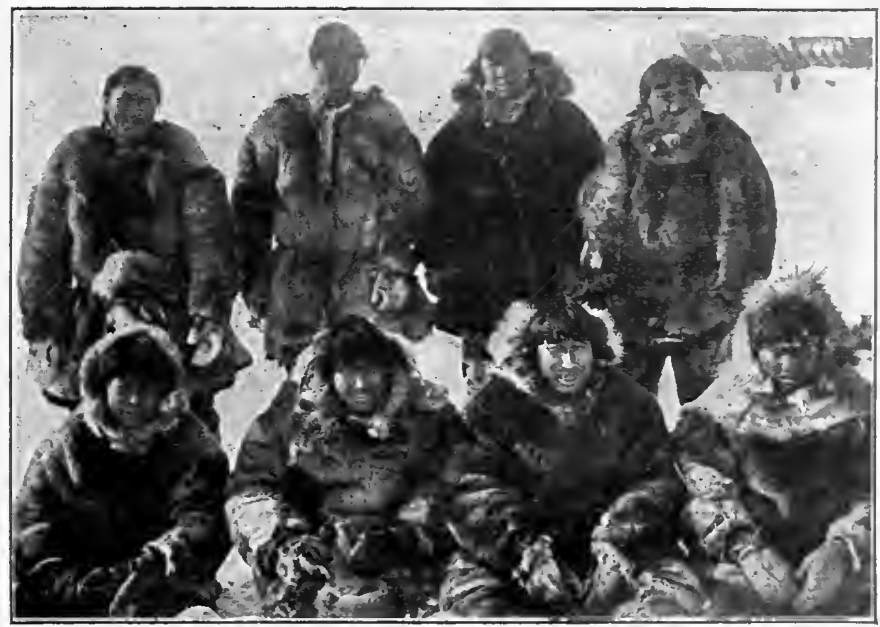

Courtesy of the Field Museum

Eskimo people of the arctic regions. These, the most northern of all people, dress entirely in skins of zeild animals. 
clothing, and to point out here and there its influence on the activities of a people. The use of

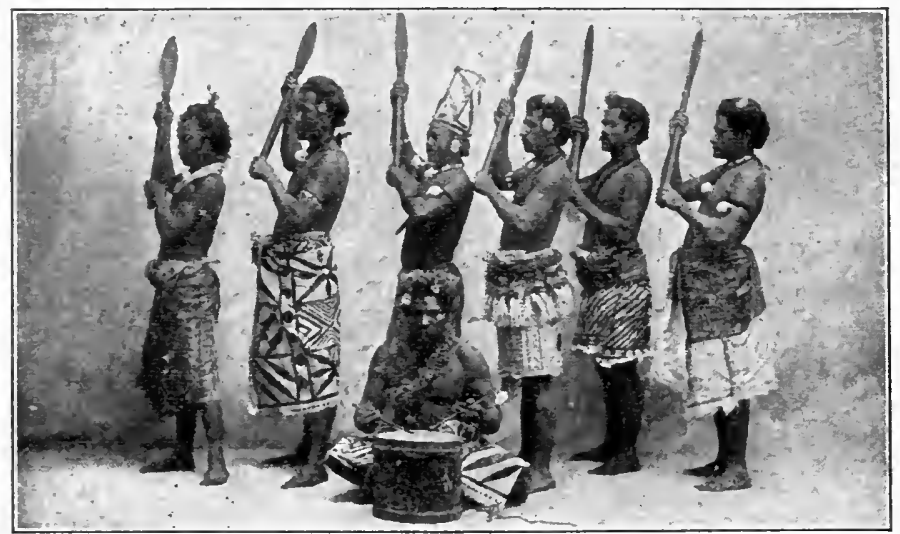

A group of South Sea islanders dressed in characteristic costume for a natiz' dance.

clothing is a sign of civilization. We judge from the dress whether a man is a provincial or a citizen. of the world. Man is the only animal that has intellectual freedom sufficient to modify or orercome his environment, and he is the only animal that provides himself with an artificial dress. The lower animals are born with their clothing ready made. The dog has his thick coat of hair; the bird, a beautiful suit of feathers; fishes, their silvery scales: and wherever similar clothing appears, even though on opposite sides of the globe, we know that the animals are of the same family. Likewise, although the clothing of a human being depends upon his own efforts, it also has racial and social characteristics; and where man's clothing 
is similar, even though found on opposite sides of the globe, we note similar stages of racial and social development.

In tropical countries there exist to-day isolated tribes in primitive seclusion making plaited leaves or bark fiber into coarse, rough garments which they tie around their waists for clothing. Likewise there exist human beings in the frigid zones appropriating the skins of animals, that is, robbing them of their clothing to protect themselves against cold. But higher than these in the scale of civilization, we find men whose cunning hands and ingenious brains have wrought out for themselves styles of clothing both complex and varied, whose habits of living affect the whole enlightened world and have a tendency to bind all people together in one common brotherhood.

Where the Arts of Living were very Primitive. At the beginning of the Christian era, nineteen hundred years ago, a very small part of the inhabitants of the world were civilized: the remainder were little, if any, superior to the North American Indian at the time Columbus discovered America. The map given here shows where the most enlightened people lived. The territory embraces southern Europe, particularly Italy and Greece; northern Africa, especially the land around the lower Nile River; eastern Asia, and portions of India and China-a territory not so large even as the United States. At this time the remainder of the world, including England, France, Germany, 


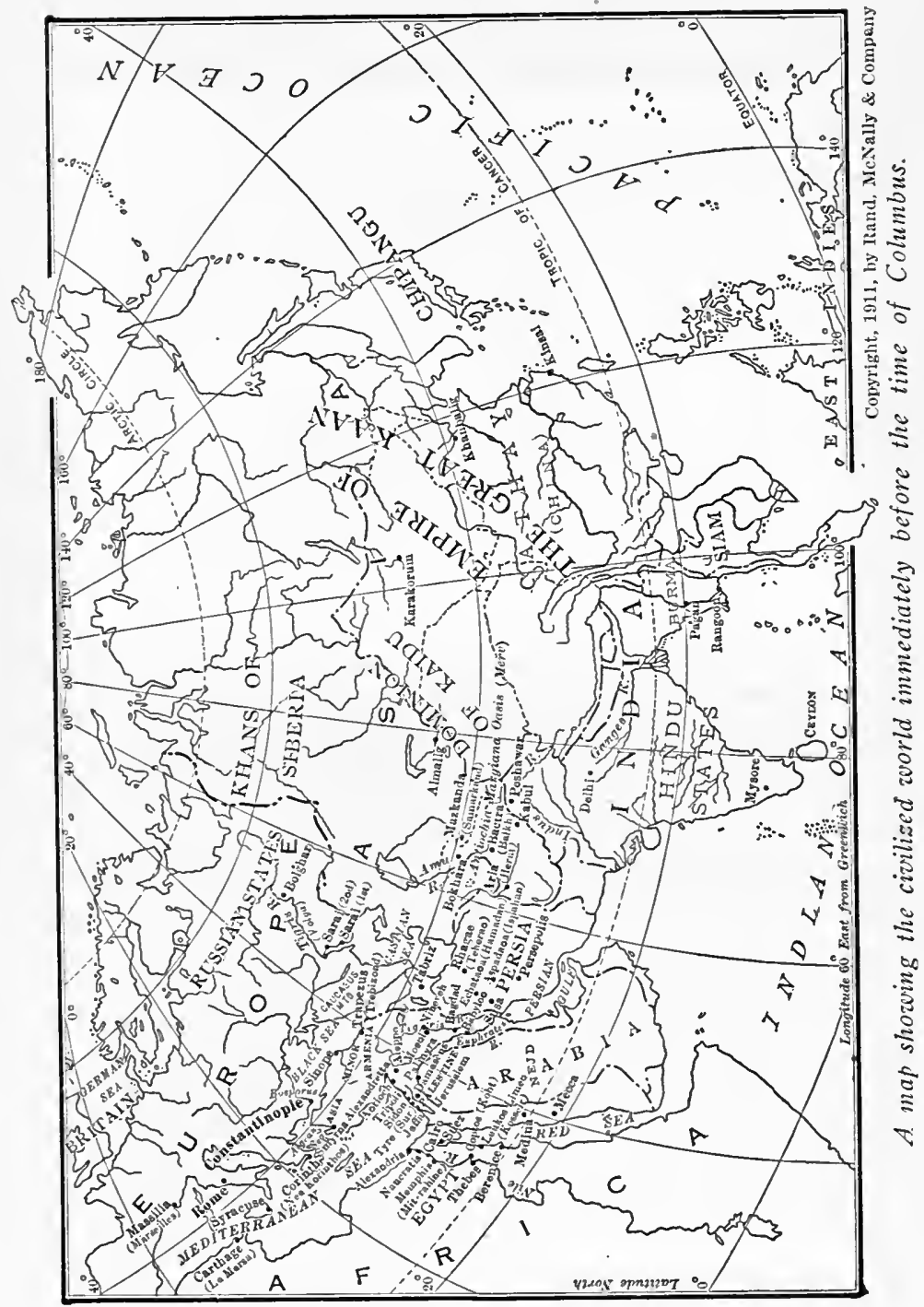


Russia, northern Asia, the whole of Africa except the northern part, all of Australia and the islands of the Soutl Seas, and all of North and South America and the islands of the Pacific Ocean, were in a barbarous or semi-sarage or sarage condition. The inhabitants were broken up into small warlike tribes. Many lived a life in the open air much like wild animals and fed on raw meat and roots, herbs, and nuts, and sometimes on one another. Many knew nothing about building houses out of timber, and they wore a dress, when they wore any at all, made from the coarsest fibers or from skins taken from wild animals. Each tribe had its own manners and customs, and, as a rule, the chief occupation of the people was war. They nsed a minimum of intelligence in producing the necessities of life, but employed muscular force almost entirely, and made war on wild animals or on the adjoining tribes.

In the tropics there were various kinds of dress, food, and shelter. In Brazil a certain tribe wore a coarse, rough garment made from the bark of trees; in Africa the natives used certain grasses; and Adam and Eve, we are told, "sewed fig leares together." In these warmer climates they simply tied the plaited leares or grasses around their waists.

In colder countries clothing was more of a necessity than in the warmer regions. The borly had to be protected against the extreme cold, and the people through necessity appropriated the 
skins of animals that they had killed for food, thus making the same animal contribute both food and

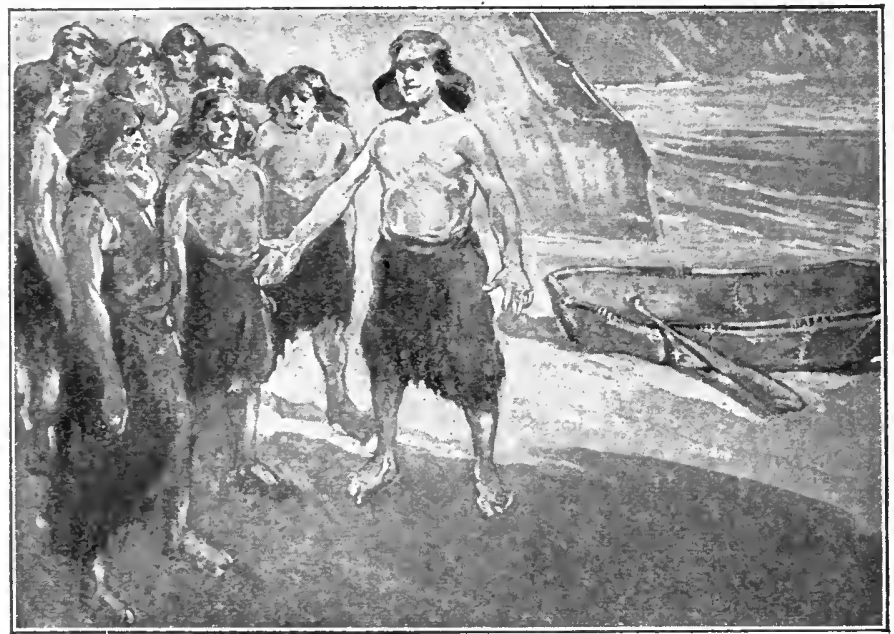

From Early Sea People by Katharine E. Dopp A tribe of primitive people. They lived by the chase and their - clothes, tents, and boats were made of skins.

clothing-and in many instances shelter also, for the tents under which they lived were usually made of skins.

While the greater part of the world was in such a low state mentally, morally, and physically, and while they were dressing in skins of animals or in coarse cloth made from grass, flax, or wool, there were people living in Asia who were dressing in fine linen and beautifully colored fabrics. It is the showy things that first attract the attention of very primitive people, and when the beautifully colored fabrics of the civilized portions of the world were 
brought to Europe they excited almost as much admiration as the beads given by Columbus and his men to the North American Indians.

Where Skill excited a World Admiration. Egypt had a wonderful civilization when the inhabitants of northern Europe were roaming the forests as wild men. The Pharaohs had large spinning establishments, such as to-day would be called factories. They not only made enough thread for home use but they shipped it to Greece, Palestine, and other countries. The ancient city of Thebes was celebrated for fine linens, and Solomon traded with Egypt and bought soft linen yarns for his own use. History is unable to look back to a time when Egypt and Palestine did not produce the finest fabrics. We read in Exodus of the holy garments made for Aaron: "They did beat the gold into thin plates, and cut it into wires, to work it in the blue, and in the purple, and in the scarlet, and in the fine linen, with cunning work." Then they made a girdle for him "of gold, blue, and purple, and scarlet, and fine twined linen."

Sidon was famous even in the days of Homer. The interesting reference is thus given in Pope's translation:

"The Phrygian queen to her rich wardrobe went Where treasur'd odors breath'd a costly scent. There lay the vestures of no vulgar art, Sidonian maids embroider'd ev'ry part, Whom from soft Sidon youthful Paris bore, With Helen touching on the Tyrian shore. Here as the queen revolv'd with careful eyes 
The various textures and the various dyes, She chose a veil that shone superior far, And glow'd refulgent as the morning star."

The Greeks were among the first people of Europe to learn from these more highly developed people of Africa and Asia. But where did these more costly goods come from? The religious codes were unfavorable to wool. Linen was used very widely, and we see frequent references to "blue and purple and fine linen." 'Where did the "blue and purple" come from? Neither the Greeks nor the Hebrews knew where much of the finer goods came from. But those nations living on the great commercial highway between the East and the West traded with the travelers who passed through their countries, bearing beautiful garments to the shores of the Mediterranean. Great trade routes were opened up in order to bring the more civilized portions of Asia closer together.

Effect of Enlightenment on Ignorance. Enlightened people seek to know the manners and customs of one another the world over. By an interchange of goods and ideas they are constantly readjusting themselves, and altering their habits and manners of living. They are ever going from one stage to another, ever increasing the facilities of travel and communication, ever drawing closer and closer together. Since dress is the sign of civilization it is necessary to take only a glance into history to see how this sign changes. Julius Cæsar, Henry VIII of England, George Washington, 
and the President of the United States to-day, each by his dress shows that he represents a different age and a different civilization.

This is not true of ignorant people. They are clannish, and seek to destroy other clans or tribes. They are selfish in their religion, and make war on other religions, and their tendency is to remain
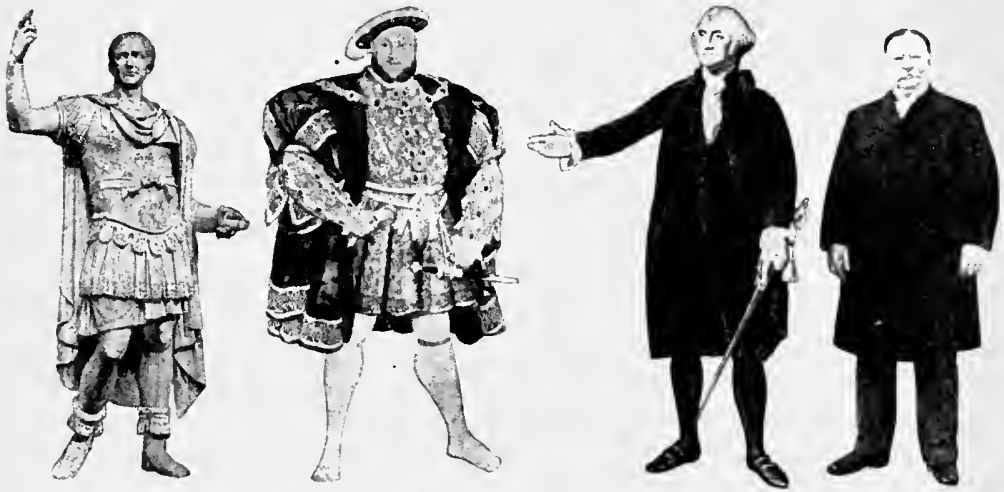

Costumes of the first century B.C. and of the sixteenth, eighteenth, and twentieth centuries.

unchanged, undeveloped, and unenlightened. But ignorant, primitive people either develop rapidly when brought into close touch with a more highly developed civilization, or perish from the earth as a race. An illustration of the former is the negro of the South; of the latter, the North American Indian.

Two thousand years ago all races, except those occupying the small portion of the globe already mentioned, were broken into tribes, ignorant and 
warlike, and isolated in manners, customs, and religion. Those tribal men were our European ancestors. Their clothes were made of skins or of the coarsest fibers, their food was much like that of the beasts of the forest, and each tribe, sufficient unto itself, was on hostile terms with every other tribe. The tribes that lived closest to the culture of the East were drawn upward by it, and they in turn changed the habits and customs of other ignorant tribes. Thus enlightenment, held above ignorance, draws all men to it.

As the world lost much of its isolation, and as tribes gave up by degrees their primitive, crude customs, there was formed a larger unity of interests. Skilled labor began to take the place of brute force. The few nations designated on the map given, because of their superior skill, due to a higher intellectual efficiency, increased their influence over the barbarous portions of the world and led them away from their primitive, brutish customs into the habits and customs of the most enlightened people.

These same forces are at work to-day. Intellectual efficiency is always superior to ignorant muscular labor. To-day a man of superior intellect, character, and skill locating in a backward rural community will have a tendency to raise the whole community and increase the intellectual efficiency of every man in it. Thus it was ages ago. The intellectual nations, though small in size and few in number, such as Egypt, Judea, Phœnicia, 
Persia, and parts of India and China, by their superior intellectual development drew the balance of the world up to them, and even beyond them.

The Brotherhood of Man. Since those days man has developed wonderfully; and as he has developed he has lost much of his coarseness and many of his brutish and beastly habits. There has developed a sympathy and a unity, and men study and have confidence in men in different parts of the world. An exchange of products and ideas of living has created a still closer unity, and men have learned to depend upon each other, though living on opposite sides of the globe. As this inte:dependence has increased, the races of men have become more and more nearly alike in their manners and customs, until to-day each section of the civilized world is dependent upon every other section for food, clothing, and even intellectual development.

One part of the world furnishes a peculiar kind of food that the remainder of the world is unable to produce; another corner of the globe supplies the world with an article of clothing all mankind needs. In order to facilitate this communication all the ends of the earth are linked together with trade lines ever increasing in their complexity, and the happiness of man on one side of the earth is dependent to a large extent upon the happiness of his neighbors on the other side.

Man no longer relies on war and conquest for food and clothing, as lie did in those ancient and 
primitive days. The human mind has invented devices and discovered methods that have made war practically unnecessary. The spindle and the distaff, the spinning wheel and the hand loom, the modern factory, the steam engine, the electric current and all the applications of modern science tell of the progress of the human mind. A new idea conceived to-day is flashed to every part of the civilized world within a few minutes after it is born, and every man who goes about his daily work in this complex civilization has to compete with every other man in the same occupation the world over.

The one force that has contributed most to this unity of the race is the desire of man to appear like his neighbor in dress and in the comfort and luxury of the home. These are the outward signs of civilization. Therefore the materials out of which these things are made are at the basis of a very large part of the world's business to-day.

The World's Clothing Material. The world in which we live is divided into three kingdomsanimal, vegetable, and mineral-and all three contribute material for our clothes. From the animal kingdom we have the skins of animals, fleece and hair of sheep, goats, and camels, and furs from the fur-bearing animals. We have also the silk from the silkworm, the gossamer thread from the spider, excreted substance from the jellyfish, ${ }^{1}$ and

${ }^{1}$ Certain people of southern France use this substance taken from the jellyfish in making gloves: 
the thread-like tentacles by which this creature feeds and clings to rocks. Many other animal products are used likewise. From the vegetable kingdom we have leaves, grasses, the inner bark of certain plants such as flax and hemp, and the fruits of certain plants, such as cotton. The mineral kingdom furnishes gold, glass, and silver. Oriental people, and kings and queens of Europe and Asia, have had garments made of pure gold and of fine spun glass and silver threads.

The materials from which clothes are made are furnished by nature in a crude or coarse state. It requires the skill and intelligence of man to invent

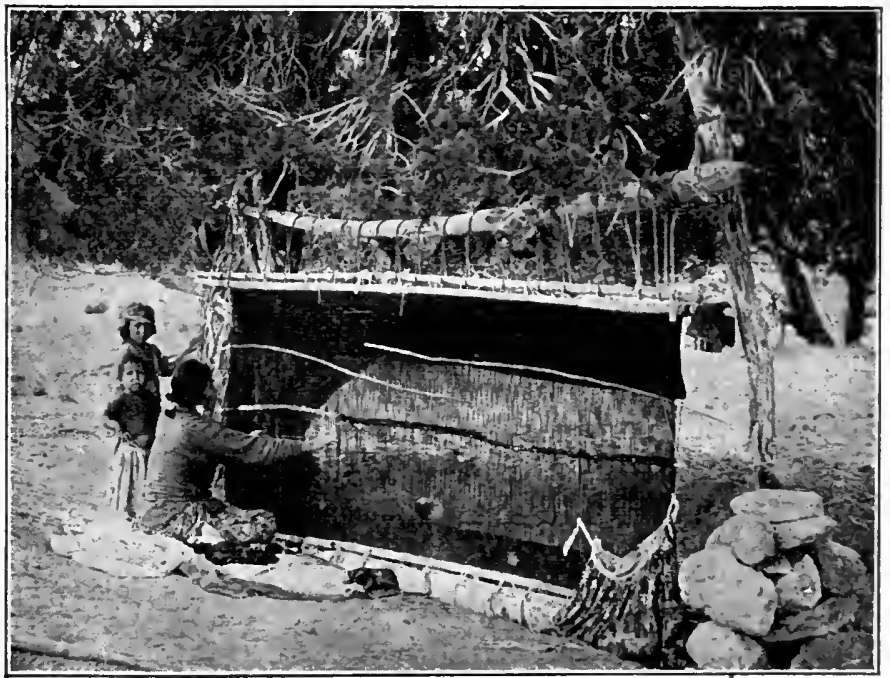

Courtesy of the A. T. \& S. F. Ry.

Hand-loom weaving of primitive people. For generations the Plains zomen have woven blankets and rugs from the flece of their flocks. 
ways of converting the coarse products into a state suitable for use; and the degree of fineness of the finished product depends upon the degree of the skill and intelligence employed.

This raw material may lie before the eyes of very ignorant people forever and be of 110 use. Nature may supply it in abundance, but unless the intelligence of man is employed in converting it, it will forever be useless. The products of the three kingdoms mentioned have been for the use of all people; but in early times it was revealed to only a few what uses could be made of them.

From all these kingdoms a few people of the world have drawn at different times their material for clothing, but of all the materials used cotton is the latest to be felt in the world's commerce.

King Cotton. A few hundred years ago it was one of the mystefies of commerce how such valuable fabrics could be made of this peculiar fiber. It was known only to a small portion of the globe, and its possibilities were not even suspected. About two centuries ago clothes and the furnishings of the home were made chiefly of wool, flax, and silk, and each locality produced-nearly all the fiber necessary for its use. Then commerce was slow, and if one branch of it was destroyed it affected but lightly the remainder of the world. If we go back a few more hundred years, we come to a time when the fiber was unknown to Europe, but the wealthy bought the beautiful fabrics and marveled at their exceeding beauty. 
The entire civilized world to-day, however, wears clothing made of cotton; and nearly, if not

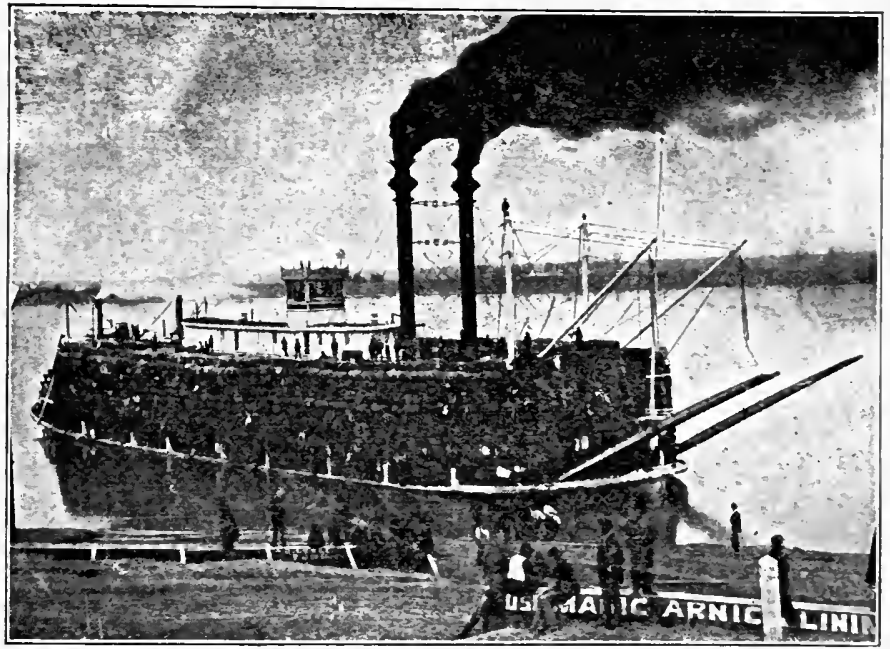

River commerce. Cotton from the Southern fields on its way to an ocean port.

quite, every civilized nation of the world has its cotton factory; but there is only one small section of the globe that furnishes this fiber in abundance, and this is the Southern States of America. All the world is dependent upon the South. For cotton is the king of clothing, hence the king of commerce, and the South is the kingdom of the king who levies tribute on the world, and the nations of the world make obeisance to him.

Cotton to-day is the friend of the poor and the luxury of the rich. It is made into cloth so coarse that it sells for a few cents a yard. It is made into 
fabrics so fine and so beautiful that it can hardly be told from silk, and so heavy and so thick that experts can barely distinguish it from wool. It is made into rope and cord so strong that it is almost the equal of flax or hemp, and into thread so fine that one pound will reach more than a hundred miles. Every year manufacturers discover new ways of preparing it, and every year the demand for it increases, and the world, it seems, cannot have enough of it. In recent years its by-products have become a food for man, beast, and plant, the possibilities of which are not yet thoroughly understood. From the arctic to the torrid zones our clothes are made of it, our books and papers are printed on it, and if, through some calamity, we should lose all goods made entirely or partly of cotton, and if all people should be thrown out of employment whose occupation is, in any way, dependent upon it-whether in the cultivation, the manufacture, or the commerce-the civilized world would be all but naked, a large per cent of it would be hungry, and the homes would be bare and comfortless.

Thus it has come to pass that this fiber, grown chiefly in one small corner of the globe, is one of the greatest agencies in producing this unity of the world, this brotherhood of man.

"What a royal plant it is! The world waits in attendance on its growth; the shower that falls whispering on its leaves is heard around the world; the sun that shines on it is tempered by the prayers 
of all the people; the frost that chills it and the dew that descends from the stars are noted; and the trespess of a little worm upon its green leaf is more to England than the advance of the Russian army on her Asian outposts. It is gold from the

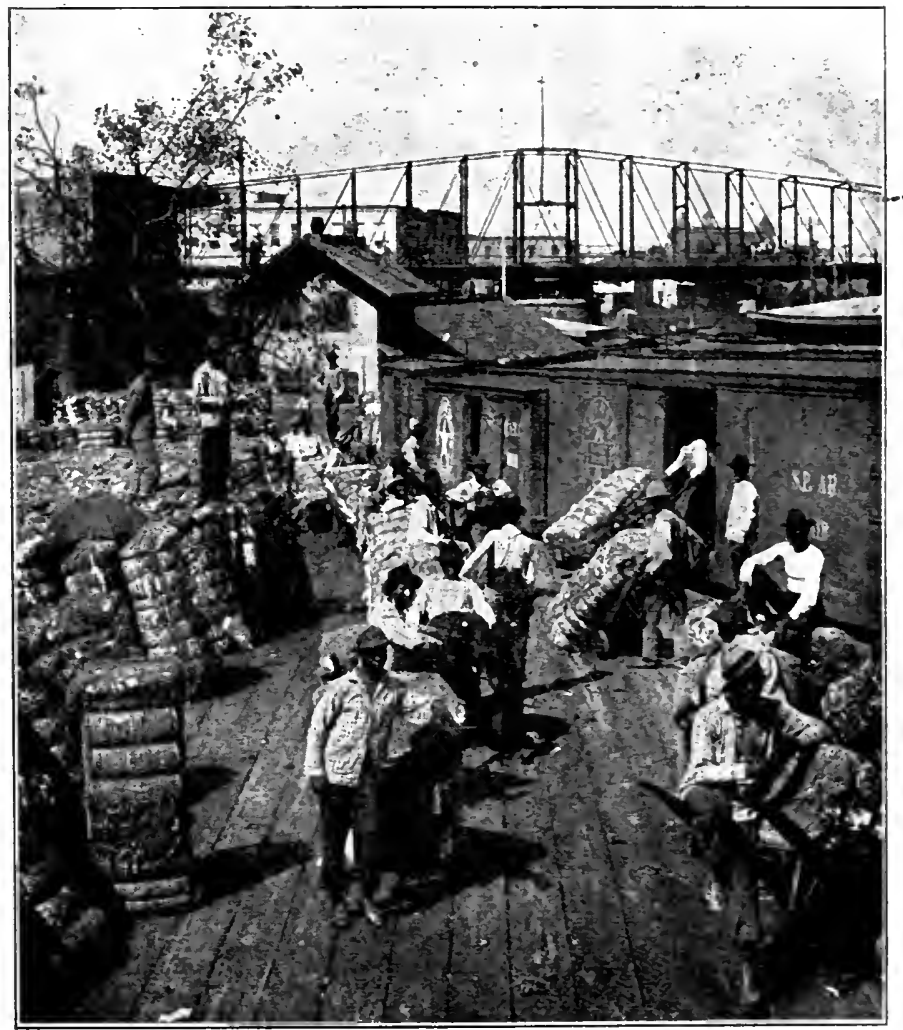

Copyright by Underwood \& Underwood, N. Y.

Shipping cotton by rail. Cars near vast cotton-growing districts being loaded with bales bound for the great manufacturing centers. 
instant it puts forth its tiny shoot. Its fiber is current in every bank, and when, loosing its fleece to the sun, it floats a sunny banner that glorifies the fields of the humblest farmer, that man is marshaled under a flag that will compel the allegiance of the world and bring a subsidy from every nation on earth." 1

1 Henry W. Grady. 


\section{CHAPTER II}

How Europe learned the Value of Cotton

The First Cotton Country. If you will take your map of Asia and trace the Euphrates River from the Persian Gulf a short distance up the river, you will come to the site of the ancient city of Babylon. In the days of Nebuchadnezzar, about 575 B.c., it was the most celebrated city in the world. All the trade of unknown India and China going westward flowed through its streets. Silk and cotton goods of finest texture were brought in by traders. But where did these beattiful and costly goods come from? The Babylonians did not know. Traders said they secured them from other traders who came from an unknown country to the eastward, and the bought them from still other traders much farther eastward. Without caring much where this peculiar kind of "wool," as they first called cotton, came from, the Babylonians bought large quantities of it. They established factories and spun and made many grades of cloth. But we are to understand that these factories were in no wise like the large factories of to-day. The cotton was spun by hand, using the spindle and distaff, and the cloth was woven by hand. They 
learned the art of dyeing; and the magnificently colored goods of Babylon became famous. For many years, as long as Babylon flourished as a commercial center, her cotton goods were in great demand in every part of the civilized world. How long the Babylonians had been buying this cotton from trading vessels and caravans, and making it into beautifully colored cloth, we are unable to say; but certainly for many, many years, for the Phœnicians, Egyptians, and Hebrews, and the people living near the Mediterranean coast, had been purchasing the goods from Babylon for many generations.

Cotton and woolen manufactures were early conducted on a very large scale. Costly dresses, carpets, and shawls of great luxury, mantles enriched with gold, and robes and draperies of all kinds came from Babylon, and on many of these garments were embroidered in gold the figures of fabulous animals. All along the Mediterranean Sea, where these finely woven and beautifully dyed garments were prized very highly, traders inquired of their origin and paid large sums for them. But where did this fine "wool" come from that could be made into such beautiful garments? And where was the original pattern?

As trade increased, travelers pushed farther and farther eastward. Beyond Assyria and the fertile valleys of the Tigris and the Euphrates, beyond the desert sands of Persia, across the Indus and over into the mysterious land of Brahma in India 
they went, seeking these beautiful goods; and 10 ! they saw a strange thing-growing all around them were "trees, the fruit of which is wool exceeding in beauty and goodness that of any sheep." This was our cotton plant with the bolls ready to be picked. Here, then, was the original home of cotton. and the center of the cotton-growing industry, the land of gold brocades, filmy muslins, and rich and gorgeous designs.

In Egypt, Phœnicia, Judea, Arabia, Persia, and India skilled workmen were producing fabrics that gave evidence of a superior civilization. Certain countries in southern Europe, such as Greece and Rome, studied the civilization of these eastern peoples and profited by their knowledge. These countries were taking lessons from them, and learning to adapt the civilization of the East to their own needs.

They were introduced for the first time to that "wool exceeding in beauty and goodness that of any sheep." Few people then could even guess that cotton would, several centuries later, change completely the manners and customs of a people, make the whole civilized world dependent upon it for clothes, influence the commerce of the world to the extent that it does to-day, and even change its home from India in Asia to the Southern States of America.

Where Cotton grew Wild. We know to-day that cotton is a tropical plant growing wild in nearly every tropical country. When the people of India 
were making such beautiful fabrics from it, it is quite probable that this plant was growing wild, coming to full maturity in due season, shedding its flowers, swinging its bolls, breaking its pods, and blowing its fiber before the gaze of the people of Asia, Africa, Australia, North and South America, and the tropical islands of the sea. But it was in India that its value was best understood, and when understood by other countries its use was at once certain.

Inhabitants of Europe knew the value of wool, and when travelers saw the cotton growing they spoke of it as "wool growing wild on trees." Wonderful stories were told of how the Hindus used raiment made of fine white cloth which was woven from the lint of the "wool-bearing tree." Travelers were fascinated with its fine, soft qualities. They studied the dress of the natives who made "linen garments of it, wearing a shirt which reached to the middle of the leg, a sheet folded about the shoulders, and a turban rolled around the head, and the linen made by them from this substance was fine, and whiter than any other."

This was the dress of the common people, but the kings wore robes "spotted with purple and gold." At this period cotton was the common clothing of the people of India, and in all probability had been for many centuries, even before the time of Solomon or Moses. Even in the remote ages, long before the secrets of India were known to the people around the Mediterranean, costly goods of 
"gold brocades and filmy muslins" came from this far-away country.

Other Countries cultivated the Wool-growing Tree. If you look at your map you will see that India and China are near together. The Chinese were great manufacturers. Their silk goods were already famous, and when they learned of the "fleece from trees" they planted it in their gardens and sang of it in their poems. Traders brought cotton from India, around the coast of Arabia, and introduced its cultivation in Egypt, where it is grown in large quantities to-day, and where it probably grew wild, though its value was unknown until Egyptians learned it from the Hindus. The Egyptians still use the old wooden plow drawn by two camels or two oxen and cultivate cotton as they did in the days of the Pharaohs.

All this occurred many years before the Christian era; and while the Greeks, Romans, Hebrews, and Egyptians were learning the value of cotton the inhabitants of England, France, and Germany were still dressing in skins or coarse goods made of wool or grass: But Europe and Asia were drawing closer together. The fine fabrics of the East were exciting the admiration of the West. Tribal lines were falling to pieces; and the habits of the East and the West were becoming similar in some respects, and one continent was becoming dependent upon the other.

Notwithstanding the efforts of the many countries of Asia and Africa to cultivate the cotton and 
to manufacture it into cloth, none was able to rival India, where for nearly three thousand years the beautiful cloth produced from the fiber of the trees, spun on the spindle and distaff and woven on the small hand loom, was not equaled anywhere else in the world. And even to-day, with our scientific knowledge and improved machinery, it is still a puzzle how the Hindus made such beautiful cloth.

The land around Jericho became noted for its cotton, and the name of a town in Syria, once called Magog, means, it is said, "cotton town." But the cotton and woolen goods of India surpassed all other goods, and soon a great demand for them arose in Europe.

How Traders found their Way to the Land of Cotton. A great writer of America has said that if a man learns the art of making anything better than his neighbors, although he may live in a deep forest, civilization will make a road to his door. Europe made a road to India, for the skill of the people of that country surpassed any skill known to the Europeans, and their habits of living excited the envy, as well as the admiration, of the wealthy of Europe. By the eleventh century great prices were willingly paid for fabrics of all kinds, for spices for their food, and for ornaments and precious stones. From that time the standard of living in Europe began to rise rapidly. About a thousand years after the birth of Christ this trade between Europe and India had become enormous. 
We read that the precious stones and fabrics, dyes and perfumes, drugs and spices, gums and valuable woods reached Europe by many devious and obscure routes, and among the fabrics were cotton goods of all kinds.

Commerce is a great civilizer. Our ancestors of Europe had been very backward. But they began to mix with the people of the East, and soon all the fabrics of India and Arabia found a way into Enrope, and before many centuries had passed Europe was dependent for her luxuries and many of her necessities upon Asia Minor, Syria, Arabia and Persia, India and the Spice Islands, China and Japan.

Our European ancestry had at last learned to appreciate the value of the skill and intelligence of the East. The old trade routes of Asia were extended now into Europe. Travelers followed the old roads which Roman soldiers had traversed across Egypt, Arabia, Palestine, and Persia. These were ancient routes when Alexander conquered the world. They were old when Babylon contended with Nineveh for commercial supremacy. They were old when Solomon built his temple, and when Moses led Israel out of Egypt; for you remember that the jealous brothers of little Joseph, when they were considering what to do with him, "lifted up their eyes and looked, and, behold, a company of Ishmaelites came from Gilead with their camels bearing spicery and balm and myrrh. going to carry it down to Egypt."

It was about $\mathbf{2} 280$ that Marco Polo, together with 
his father and uncle, traveled throughout China, where cotton was then grown. They were traveling in the interest of the cotton trade with the East. Marco Polo in writing of their trip said the natives were producing "the finest and most beautiful cottons that are to be found in any part of the world." By this time it appears that China had learned not only to grow cotton, but also to make the beautiful fabrics.

The southern countries of Europe, the northern tribes of Africa, and the western people of Asia made great efforts to raise this valuable fiber and manufacture it into cloth, but none succeeded so well as the people of India. In the fourteenth century great cities were built up in Europe on the trade between Europe and India. Venice and Genoa are two of them. The old trade routes grew in importance, and other routes were established. Long trains of camels came nodding across Asia Minor with bales of costly goods on their backs, and light vessels braved the raging storms of the Indian Ocean bringing goods from India to Europe.

\section{Venice and Genoa became Great Markets of Eu-} rope. Venice and Genoa now rivaled the ancient city of Babylon. They bought great quantities of goods in the East and sold them to the inhabitants throughout Europe. Spain, France, England, and Germany were dependent to a large extent upon these cities for the luxuries of the home. These two cities were to all Europe what New York is to 
a large part of America-the distributing point for the finest goods of the world. Great banking

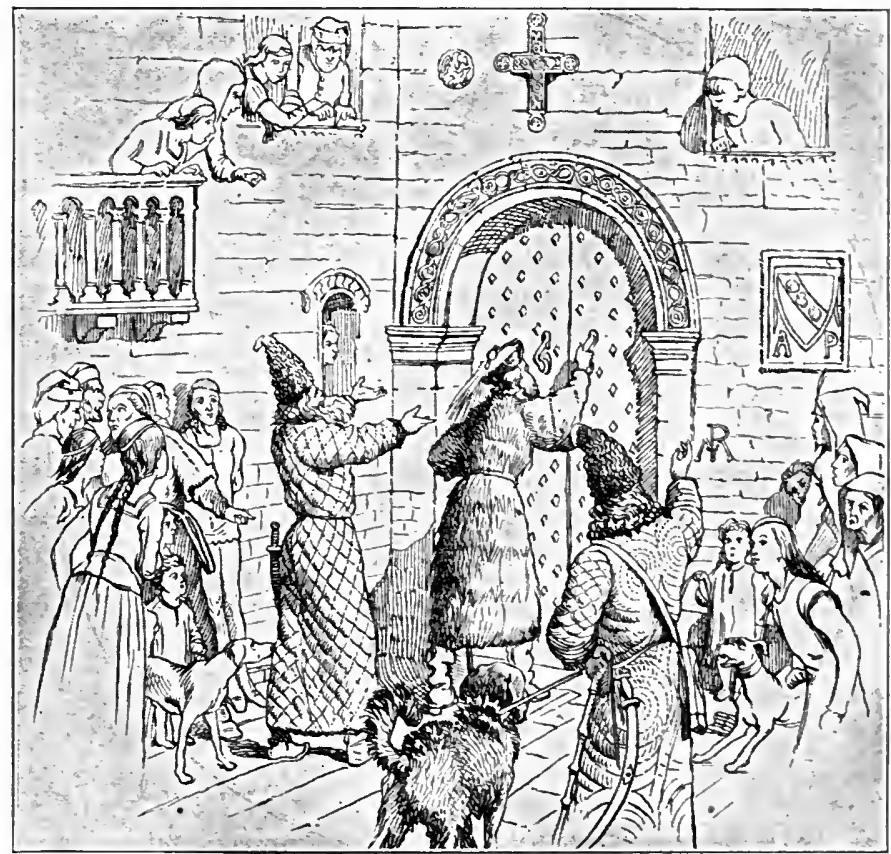

After the Medallion in Yule's Life of Marco Polo

This pictures the arrizal of the Polos at their home in Venice on their return from China.

houses grew up. Merchants came thither to buy, and Vcinice and Genoa became very rich and powerful. Even the cities along the Baltic and the North Sea looked to Venice and Genoa for these goods. In northern Europe, Hamburg and Lübeck grew great and became distributing points for goods that were brought from the Italian cities. 
In order to increase this trade, agents for the large mercantile houses were sent into China and India. Like traveling salesmen of to-day, they bought and sold for their employers. Travelers also visited the East on their own account, for the wonderful stories of the wealth, luxury, and culture of the East excited universal interest. Sir John Mandeville of England said he saw the cotton plant growing. But he magnified everything, and told

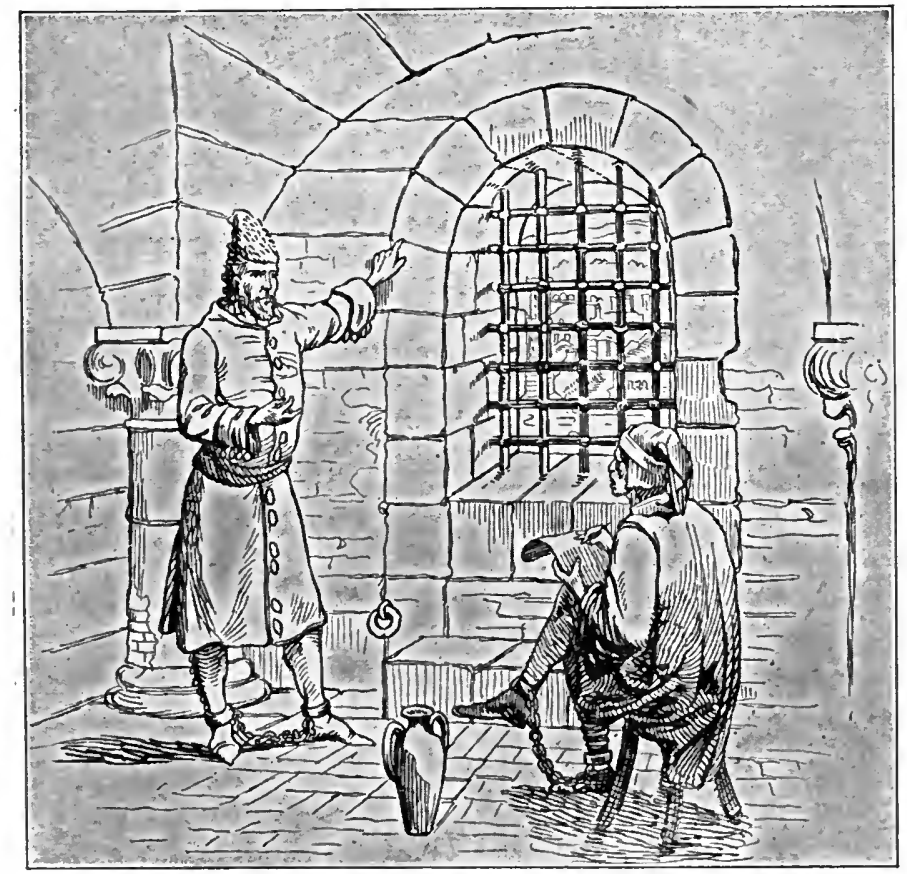

After the Medallion in Yule's Life of Marco Polo

This scene reveals Marco Polo in prison, dictating an account of his adventures. 


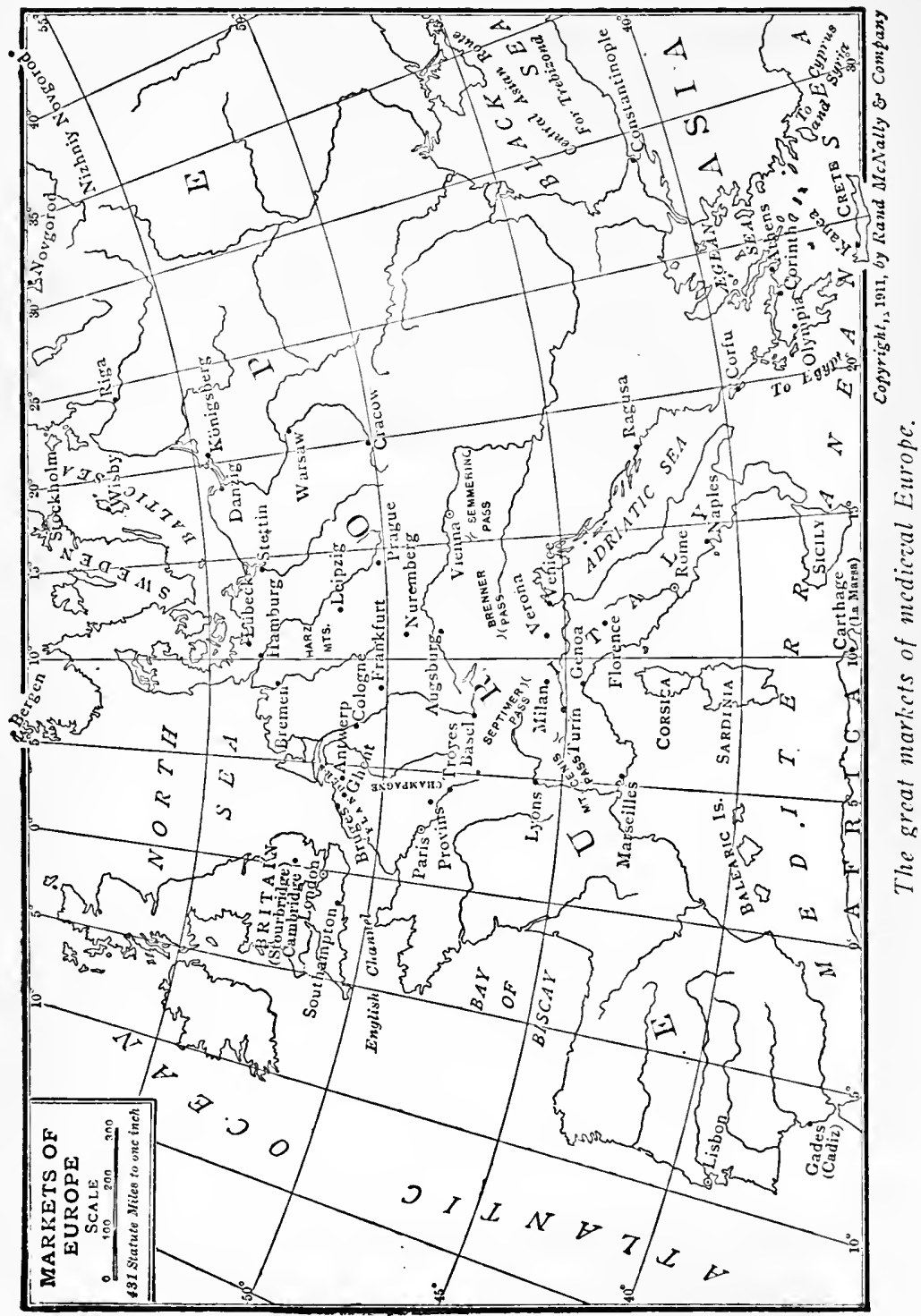


impossible stories of many things that he never saw. In describing the cotton plant, he said it was a littie beast which grew as the fruit of plants, that he had seen it grazing on the grass around the tree, that it had flesh like other animals, and that he had seen and eaten the flesh himself. It is useless to tell all the absurd stories that are told of this plant growing in the East. Fabrics made from it were so fine and so valuable that many of the most intelligent people of Europe could not understand the fiber from which it was made. This fact accounts to some extent for those queer'stories, for Europe knew how to make only the coarser goods from wool and flax.

Effect of this Trade on Europe. As the people of France, England, Spain, Italy, and Germany developed they improved their manner of living. Their dress was selected with a view to appearance and comfort. Their houses were better furnished. Carpets, rugs, and curtains were introduced. They improved their food; they learned to cook better, and to use spices for flavor. They learned to dress better, to wear the finer. clothes of purple and gold, and to adorn themselves with jewelry. All these luxuries came from the East-from China, India, Arabia, Persia, the Spice Islands, and elsewhere. Europe had learned to appreciate, but had not acquired the skill to produce, these fine goods. They came overland to the Black Sea, where the merchants of Genoa received them in their vessels. They came by Bagdad, or Alexandria, and by way 
of Tyre and Sidon. Thousands of camels were employed and many thousands of vessels were used in bringing these goods to the Italian cities, from which points they were distributed to the cities of Europe. The East was educating the IVest, and Europe readily appropriated the goods of Asia and adapted them to her own uses and to the improvement of her civilization.

Venice triumphs over Genoa. Venice was the natural distributing point for northern Italy and Germany. Genoa, which had the better harbor, sold the goods to Piedmont and Lombardy, thence to Pisa, Florence, Milan, and across the Alps. Genoa for the time had the monopoly of the trade between the Mediterranean and northern Europe. But Venice and Genoa were deadly rivals, and after about a century the former came out victorious, and her fleets were dispatched in large companies to all the ports of Europe filled with the most precious goods of the East-"silks; satins, damasks, cottons, and various other costly gear, as well. as spices, saffron, camphor, and a hundred other articles."

Shakspere, in The Merchant of Venice, says of Antonio's argosies:

"With portly sail,

Like signiors and rich burghers on the flood, Or, as it were, the pageants of the sea,

Do overpeer the petty traffickers,

That courtesy to them, do them reverence,

As they fly by them with their woven wings."

One fleet went to the Black Sea, another to 
Egypt and the Greek empire. Another was called the "Flanders fleet" because of its destination. It halted as it passed through the Mediterranean and traded with the ports of Italy and Spain. This fleet distributed goods along the English coast and touched the Flemish ports. Thus the trade be-

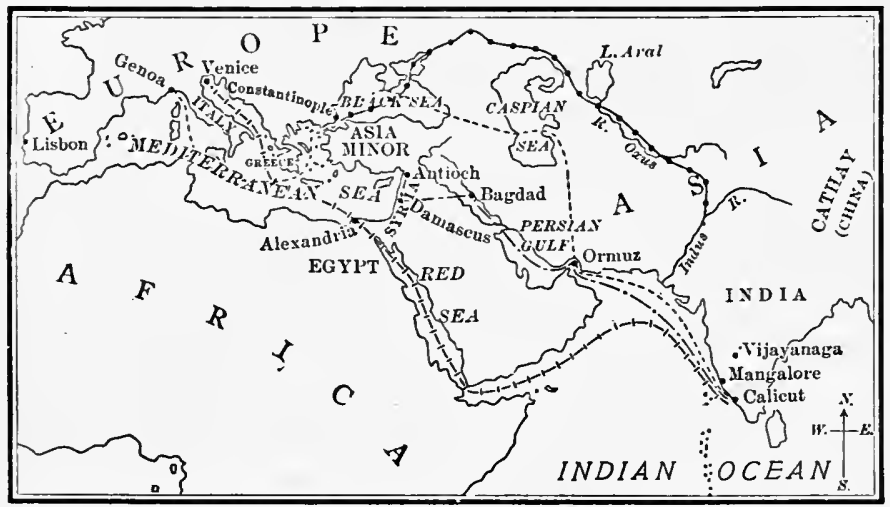

Northern Route Controlted by Genoa -

Southern Route Controlted by Venice

- Middle Route -

Ancient and medieval trade routes.

tween the East and the West, whose origin is lost in fable, reached this enormous business with Venice as the great southern center and distributing point.

The Trade Routes clearly defined. Suppose we notice again how this trade reached Venice and Genoa :

I. From India, by way of the Indian Ocean and the Red Sea, to Alexandria, and thence to Venice.

2. From India, by way of the Persian Gulf, the Tigris and the Euphrates rivers, thence to the 
Black Sea and beyond by way of Constantinople.

3. From the Indus River, by way of the Oxus and the Caspian Sea, thence across the Black Sea and by way of Constantinople.

Why Columbus discovered America. Suppose we study the map of Asia and Europe again and learn what were the principal countries these trade routes crossed. In going from India to Venice and Genoa traders had to go by way of Constantinople. the eastern shore of the Mediterranean Sea, or by the Indian Ocean to the Red Sea and thence across Egypt to the Mediterranean Sea. Any force, therefore, that should interfere with this trade would necessarily injure Venice and Genoa and seriously disturb or destroy the entire commerce of Europe. And this is what happened.

In the seventh century after Christ there came a man to Arabia who founded a new religion. His name was Mohammed, and his followers are called. Mohammedans. The inhabitants of Arabia soon became the followers of Mohammed. They moved up into Asia Minor, then over into Egypt and along the northern coast of Africa, and finally crossed the Strait of Gibraltar and established a kingdom in Spain. They next crossed over from Asia Minor. and about the middle of the fifteenth century captured Constantinople. They now held possession of all the trade routes between Europe and Asia. The Mohammedans, being great enemies of the Christians of Europe, destroyed that trade and made war on Europe. This caused the ruin of the 
great mercantile houses of Venice and Genoa. It caused great distress in Europe, for nearly every comfortable home was affected.

How could Europe secure these valuable goodsclothing and ornaments for themselves, furnishings for their homes, spices for their food, perfumery for their clothes, and medicines for their afflicted? They must reach India! The Italian cities were affected most. Venice and Genoa were on the verge of ruin. All Europe looked to these cities for their luxuries and a large part of their necessities; and they looked to India, but their trade had been cut off. They must find a new route to India.

This distress had come to Europe about the middle of the fifteenth century, when Columbus was a small boy. You remember how navigators, urged on by the Italian cities, made repeated attempts to sail around Africa, and finally succeeded. You remember how Columbus argued that it would be easy to reach India by sailing westward. You recall how he labored for more than ten years to convince the people of Europe that he could prove his statements if he could secure aid. You remember how he secured assistance from the king and queen of Spain, how he fitted out his vessels, how he sailed westward, and how he discovered America.

He gave to the world a new continent, and lo! in this new world he saw the cotton plant growing wild as in India. No wonder that he thought he had found India by sailing westward! 
What the Natives knew of Cotton. Those who followed Columbus found cotton growing on the islands of the West Indies. Cortes, who made a conquest of Mexico, found the natives highly, skillful in weaving and spinning cotton. The Montezumas presented him with curtains, coverlets, and robes of cotton cloth, many of which were as fine as silk. He carried away an abundance of cotton cloth, much of which was very fine.

In this new world cotton was growing in many places, and as tall as small trees in a few countries. Pizarro, who conquered Peru, found cotton growing there, but it was of a brownish color. The Peruvians knew much about its cultivation and many uses. Their mummies, which had been buried for ages, were wrapped in cotton cloth.

Cotton was found as far north as the West Indies and the Rio Grande and probably as far south on the Atlantic coast as Brazil.

The Mexicans understood the art of dyeing, for they had "exquisite cotton fabrics dyed in various colors." How long cotton had been cultivated in these countries it is impossible to say. It is probable, however, that its uses here are as old as its production in India; and that while the Babylonians were making clothes of beautiful colors, these exquisite cotton fabrics were also being made and woven by the Mexicans.

The Commercial Center of the World is changed. With the discovery of a new continent, and a new route to India by way of the Cape of Good Hope, 
ideas in regard to the world were changed completely, and a new era began.

India and the East are from this time reached by other routes. The center of the world's trade is moved to the west coast of Europe, and the great mercantile cities on or near the Mediterranean Sea lose their importance. These countries of the East were great because of their skill in the arts of living. They taught the barbarous Europeans how to live, but they did not have the capacity for so much growth and continued increasing skill as the Europeans; and from the discovery of America until the present day we look more and more to the races of Europe and America for supremacy in all the arts of living.

This change from the East to the West carried disaster to all cities beyond the Alps that had depended for existence on the trade with Venice and Genoa. The Portuguese, the Spaniards, the English, and the Dutch began their struggle for supremacy, and the English Channel and the North Sea, instead of the Mediterranean, became the center of commercial activity.

Changing the world's commercial center affected the customs and occupations of the people. India was too far away. Europe was learning some of the arts of the East and acquiring some of the skill; and cotton must be secured elsewhere, for India would ship but little raw cotton. It must be secured in America.

How Different People named Cotton. When the 
people of Europe first saw cotton growing it was so much like the wool they were acquainted with that they called it wool. It was discovered growing in many places, and each people called it by a different name. The inhabitants of India called it karpasi; and in one of their laws they said the sacrificial thread of the Brahman must be made of karpasi. A certain Roman poet, writing of the people of India, referred to them as those

"Who drink the sparkling juices from tender cane,

With dyes of crocus stain their hair, and fix

With colored gems the flowing Carbasus."

This is the same word as the karpasi used above. The spelling only is different.

In upper Egypt, where they learned later to cultivate the plant, it was called gossypion, but the Arabians spoke of it as kutn. The French later called it cotn, and the English spelled it cotton. Kutn, cotn, cotton; this seems to be the derivation of the word. The German word for cotton is baumwolle, which means "tree-wool."

If we trace its origin still further we find that cotton belongs to a certain family of plants one branch of which is Gossypium (gossip-i-um) and is closely related to the hollyhock and the milkweed. 


\section{CHAPTER III}

Origin of Cotton Culture in the United States

The Nature of the Cotton Plant. We have learned that cotton grows wild in the tropics, that it can be cultivated in the warm climates near the tropics, and that many years before Sir Walter Raleigh organized his first colony for the purpose of making settlements in America, England knew the value of the cotton goods made in India, Arabia, Egypt, China, and Mexico. In all of these countries it grew with very little cultivation. The seed had to be planted in many places only once in about every seven years, and the cotton could be gathered twice a year. The fiber was very fine, and the seed barely adhered to it. It was therefore very easy to shake the seed out, or in many instances to whip them out with switches. Therefore it required little labor to raise this cotton or to separate the seed from the lint.

Some time before the settlement at Jamestown the inhabitants of Manchester, England, learned of refugees from Holland how to mix cotton with wool and weave it into cloth, but all of the cotton used in this manner was brought from India or Egypt and was very costly. The people of Spain, France, Italy, and Greece learned to grow cotton 
in the warmer climates, but they could raise barely enough for their own use. England could raise none. Therefore, in the early days of the first settlements at Jamestown, an attempt was made to cultivate cotton. If it could be raised at a less cost than wool or flax it would be a great saving not only to the colonists in America but even to the people of England. So the first settlers at Jamestown had hardly made their first crop when it was advertised abroad in England that cotton would grow here as well as in Italy.

Its Habits in the South. It was some time before the settlers learned the peculiar habits of cotton in America. When should they plant it? How should they cultivate it? In the tropics it grew wild. When it was cultivated, in many places they had to plant it only once in seven years; but at Jamestown it died down in winter and would not come again in summer. They tried many kinds of seed, but when grown in the colder climate of America, all its tropical habits were changed.

Within a few years, however, certainly before I6r9, when negroes were brought to Virginia, in the reports sent out cotton was mentioned among other commodities that were produced along the rivers of Virginia.

Seed brought from Italy, the West Indies, Egypt, Siam, India, and other tropical and semi-tropical climates were many times crossed in cultivation. hence the plant that has finally survived in the South Atlantic States is a different species. It is 
unlike the cotton of the tropics and is a puzzle to the botanist of to-day. The lint is not so fine.as that of India; the plant is smaller, and requires replanting every year and a great deal of labor to make it profitable. But the most difficult thing about this hybrid plant is in the separation of the seed from the lint. Unlike the tropical cotton, it adheres so closely to the seed that it cannot be shaken off, whipped off, or rolled off, and it is with much difficulty that it can be picked off.

The colonists coming from England brought with them their knowledge of spinning and weaving. By the middle of the seventeenth century a great army of hand weavers had developed in England, and many of them came to America. When they settled in the South they almost immediately planted a small patch of cotton, for wool was scarce and clothing hard to get. The kings of England and the early governors of the colonies displayed much interest in the cultivation of this plant, for every year the cost of clothing was going higher and higher. The colonists were urged and encouraged to cultivate cotton; prizes and bounties were offered planters; but with all this, the difficulty of separating the seed from the lint stood in the way of a planter's producing more than enough for the immediate needs of his family. In many instances he even preferred to raise flax and wool.

How England encouraged its Cultivation. The need of cotton in England especially caused almost 
every large body of settlers to bring cotton seed with them. When Sir John Yemans sailed from the Barbadoes up the Cape Fear River in North Carolina he brought seed and planted them along the river. When the first governor of South Carolina received his instructions from England he found directions for him to supply himself with cotton seed and to receive the products of the soil in payment for rents, and the price of cotton was fixed at three and a half pence, that is, about seven cents, per pound. When the French opened up the lower Mississippi Valley they advertised that the shortstaple cotton was grown there, and that in all probability the long-staple could be profitably grown also. The Spaniards in Florida advertised abroad that the "cotton tree was growing in that country." When General Oglethorpe led his colony into Georgia, land was parceled out in small lots to his soldiers and they were instructed to raise cotton. They planted small patches, and their wives made the thread and knit it into stockings. This fiber was so unlike the India or Egyptian fiber that the early settlers were unable to use it except in a limited way, and, too, by mixing with the coarser fibers.

As the settlements increased, the number of cotton patches increased. Every farmer's wife needed a little cotton for making bed quilts and stockings, and for mixing with wool and flax in making the coarser goods. In this way each planter could use a few pounds annually.

The rich or well-to-do planters bought their finer 
clothes from England. And sometimes a man was wealthy enough to give his wife a calico dress, the goods of which originally came from India. This class of goods was usually shipped from Calicut, India, where calico printing was first practiced: hence the name calico.

Extent of the Cotton Patches. In the beginning of the eighteenth century, however, cotton culture in North Carolina had reached the extent of furnishing nearly one fifth of the people with clothing.

John Lawson, who wrote a history of North Carolina about this time, says: "We have not only provisions plentiful but clothes of our own manufacture which are made and daily increase, cotton, wool and flax being of our own growth, and the women are to be highly commended for industry in spinning and ordering their housewifery to so great an advantage as they do."

These small patches of cotton were found on nearly every plantation in the South where the soil and climate were favorable. A snall plat in the garden, or less than an acre in the field, supplied a family with lint for stockings and clothes. But England was anxious for the South to raise cotton on a larger scale.

Notwithstanding all these efforts, cotton raising was not profitable except for home uses.

The Difficulty of removing the Seed. Did you ever take a handful of cotton just after it had beeil gathered from the stalk and try to pick the seed from it? Try it, and see how closely the seed cling 
to the lint, how they hold the lint and refuse to give it up. This is where the trouble was in raising cotton in the South. The India cotton was vastly different. You could almost shake the seed out. But how were the colonists of the South to separate the seed from the lint?

Here is the way it was done. The wealthier planters or farmers in the earlier days owned a dozen or more slaves. In the winter months, during bad weather, and at nights, the slaves would bring the baskets of cotton from the barn, or from the attic of the planter's house, and the seed was picked by hand. The poorer farmers had more difficulty. After their day's work the good man and his wife and children, sitting around the open fireplace that roared with the leaping flames of a light wood fire, would bring the basket out from under the bed and pick seed until bedtime. Sometimes the neighbors would come in and all together, talking and laughing, would pick seed until late at night. Usually a shoe full of lint was a good night's work for any one person.

So tedious was the process that it took one man a whole day to pick one pound of lint. By a little calculation you can see that it would take such a man nearly two years to pick enough lint to make a bale of cotton. Yet this is the way the early settlers secured their cotton for spinning and weaving. It is no wonder that they did not have any to sell.

How Settlers encouraged Manufacturing. There 
were no large manufacturing establishments in America in the early days. The average citizen had very little money with which to buy things. He made what he needed, and what he could not make he usually did without.

The early settlers were compelled to teach their children how to spin and weave. In many colonies the courts ordered the parents to teach both boys and girls the art of spinning and weaving. In the North they used wool and flax principally; but in the South they used much cotton in addition, and in nearly every colony prizes were offered by the government for the best fabrics woven. In Boston a school was established for teaching boys and girls this most valuable occupation.

In the North wool frequently became scarce, and sometimes laws were passed against killing sheep, because these settlers relied almost entirely upon wool for their winter clothing and upon flax for their summer clothing. Everywhere the people planted patches of flax, and nearly every family had a flax brake, distaff, spinning wheel, and loom. The Middle States, seeing that the cotton raised with profit in the South could be mixed with wool, attempted to cultivate it. It was cultivated with some success in Maryland, Pennsylvania, Delaware, and New Jersey. At the time of the Revolution the home-grown cotton in Pennsylvania was sufficient to supply many of the domestic needs of that state.

How Cotton was prepared for Spinning. The 
people of the colonies had a peculiar way of preparing cotton for spinning after the seed were removed. It was carefully washed and cleaned by women and children. While wet it was beaten thoroughly with willow switches, hence the term "willowing." The son of a weaver tells this interesting story:

"I recollect that soon after I was able to walk my mother used to bat cotton wool in a wire riddle. It was then put into a deep brown jar with a strong layer of soap and suds. My mother tucked up my clothes about my waist, and put me into the jar to tread upon the cotton at the bottom. When a second riddle full was batted I was lifted out, it was placed in the jar, and I was put in to tread it down. This process was continued until the jar was so full that I could no longer safely stand on it, when a chair was placed beside it, and I held on by the back. When the tub was quite full the soap-suds were poured off and each separate lump of cotton wool was well squeezed and placed under the beams of the kitchen loft to dry. It was then carded and put aside for spinning."

It was an unusual family that had so much lint cotton to spin; for a jar large enough for a little boy to stand in would hold several pounds.

It must be kept in mind that this was a peculian kind of cotton that was introduced into the South. It was only after many successive efforts and many years that the people were even able to produce this fiber in the temperate zone, and especially as 
far north as Jamestown. They had to create a new species first, and this required many years of labor.

Difficulty in manufacturing Cotton Goods. Our great-grandmothers learned in England and in Holland how to spin cotton, but they were never able to make a tight, strong thread of it. When it was completed and at its best, it was loose and very weak, but when it was woven into cloth, having either flax or wool for the warp, it gave a soft, nappy feeling to the cloth which made it better for wear. This is why the cotton made in America could not be used at first in the manufacture of the finer goods.

If you will examine a piece of cloth you will see threads running two ways. The long thread is called the warp and the cross thread is known as the woof or weft. The women of the South had learned how to use the cotton for the woof. But the warp had to be made out of a strong thread, for this was the thread that ran the long way in the loom and held the cloth in the frame. The woof could be of a weak thread, for it was used in the shuttle and was carried back and forth, with little strain upon it.

England tried to discourage the manufacture of cotton goods in the United States, even objecting to the manufacture of it for home use, for there had already developed in Manchester a great manufacturing center. Daniel Defoe, author of Robinson Cruso, wrote in 1727 , more than a hundred years after the Puritans settled in Massachusetts, 
that "the grand manufacture which has so much raised this town [Manchester] is that of cotton in all of its varieties."

But this cotton did not come from America. It was shipped from India and Egypt. Later it could be bought in the West Indies and Brazil. In America the planters used all they made and more. They even imported it from the West Indies and Brazil; for the cotton produced in these tropical or semitropical countries was of a long-staple variety and could be separated from the seed more easily.

Many efforts were made both in America and in England to manufacture the finer goods, such as were found in India, but without success. The coarse thread made of the cotton grown in America could be made into cloth only when mixed with wool or flax. Nevertheless experiments were continually being made in an effort to make a thread that was as fine as the thread spun in India.

You have seen the common milkweed with its long pods and white silky lint that flies away on the winds. This is closely related to the cotton plant, and the fiber is not unlike the lint of cotton. Our ancestors used it for stuffing bed quilts, and experimented frequently with the fiber. They tried to spin it, but they could not make it into thread. It was so easy to separate from the seed that, if they could use it in spinning, it would be more valuable than cotton. But they never succeeded.

What they were trying to imitate. The great desire of the time was to learn the art of making 
the fine laces, muslins, brocades, and calicoes that came from the East. England was more interested

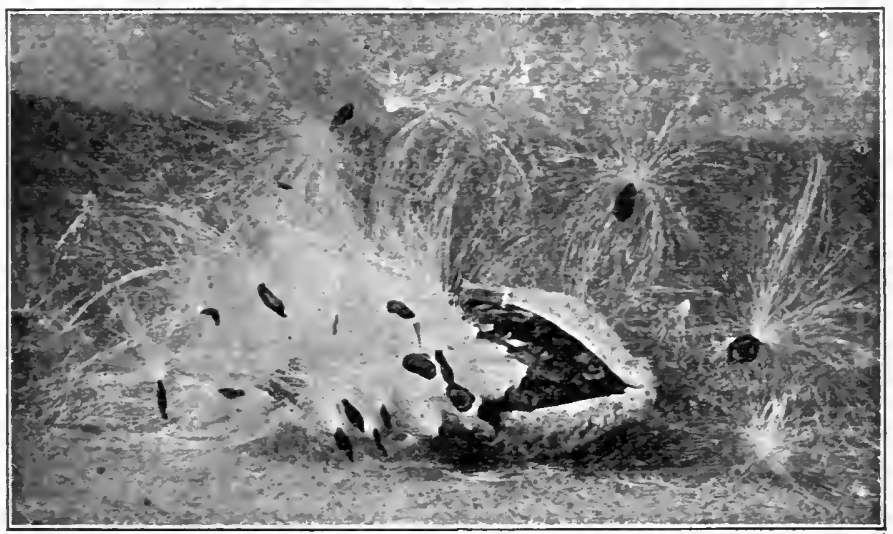

The silky fiber of the milkweed. This beautiful athite fiber is too weak and brittle to spin.

in this art than were the colonists. The majority of the people of America never even saw these finer goods, though they heard many wonderful tales of their exceeding fineness and wonderful beauty. One writer describing it said, "When a man puts it on, his skin appears as plainly through it as if he were quite naked."

Another story was that "some calicuts [notice what they called it] are made so fine you can hardly feel them in your hands, and the thread when spun is scarce discernible." The rich of India wore turbans so fine that "thirty ells of the cloth put into one turban weighs less than four ounces." It was said that "when the muslin is laid on the grass to bleach, it is no longer discernible." 
These were the goods that excited the envy of all the wealthy people of Europe and America. It was known that many of them were made of cotton, but how different were these goods from those made by the spinners and weavers in America! Merchants spoke of the fine dress goods as but "the shadow of commodity," or "webs of woven wind." A few of the wealthier people in America were able to buy some of the calicoes and brocades for their wives. Here is an interesting story told of Benjamin Franklin:

One night in the year $175^{\mathrm{I}}$ his home was entered, and his wife's most valuable dress, which was made of cotton, was stolen, and the next day Franklin advertised for it as follows: "Whereas on Saturday night last the house of Benjamin Franklin, printer, was broken open, and the following things feloniously taken away, viz., a double necklace of gold beads, a woman's long scarlet cloak with a double cape, a woman's dress of printed cotton of the sort called brocade print, very remarkable, the ground dark, with large red roses, and other large and yellow flowers, with blue in some of the flowers, with many green leaves, etc."

This was a very valuable dress if it was of such gay colors. Only the rich could afford it, and it was the marvel of the colonists how such beautiful coiors and such fine goods could be made. 


\section{CHAPTER IV}

Development of Skilled Workmen in America

Economic Strength of the Colonies. If the two great essentials, food and clothing, are not the product of one's own efforts there cannot be independence; for the road from dependence to independence, from slavery to freedom, is an economic one. Before a people can be independent politically they must be independent industrially; they must be able by their own efforts to acquire for themselves something more than the bare necessities of life. They must first be able to control the necessities; then freedom begins.

When the colonists from England settled the Atlantic seaboard they were at first absolutely dependent upon England for both these necessities of life. They were like children crying to a mother for food and clothing. The history of the first few years tells of starvation and intense suffering. Pathetic appeals went back across the wide Atlantic to their little island home, asking for food and clothing. But when these early pioneers learned how to draw on the wild animals for both these necessities, when they learned to husband their resources and to draw from the soil and the forests more than the bare needs of the body, an entirely 
different spirit came over the land. Then a governor sent over by the king, or special laws enacted by parliament, became hindrances; and the colonists began to feel the restrictions to freedom.

The first half of the seventeenth century was a time of adjustment to new conditions-primeval forests, virgin soil, the ways of the red men, new foods such as the potato and Indian corn, different climate, different animal life, and different manners and cistoms due to the amalgamation of different people. In the original colonies there came together the Swiss, the Swedes, the Germans, the Ditch, the Scotch, the Irish, and the French as well as the English. Each people gave up by degrees its national characteristics, although very slowly, and a new nation was the result.

How the World had prospered Economically. In their European homes these different peoples had been in touch with a progressive world spirit Germany had years before established her spinning schools and held the rod over boys and girls, driving them toward efficiency in the arts of living; Flanders had already reached the Master's degree in the arts of spinning and weaving; France had long since expiated for the crime against the $\mathrm{Hu}$ guenots, ${ }^{1}$ her best workmen; beyond the Alps, fine silks rivaled the purple and gold that came from

${ }^{1}$ Louis XIV of France revoked the edict of Nantes, which had given religious freedom to the Huguenots, the protestants of France, and they fled to Flanders and England. The Huguenots were the best spinners and weavers of France. 
the East; England's wool industry was receiving the attention of king and parliament, and Ireland was acquiring fame for her fine linen yarns. All Europe, which had once been so dependent upon the East, had moved up on a plane of activity that spoke of economic independence. Each nation, jealous of every other nation, sought to equal and even surpass the skill of the others. The days of primitive isolation and tribal warfare were far in the past centuries, and each nation of the globe was but a part of the civilization of the whole.

Settlers coming to America from each of these European nations brought with them their skill. and they soon learned to ply their trades in this new world. The colonies even advertised for these skilled workmen and advertised the advantages of this new continent, and it was practically useless for the mother country to pass laws restricting the skill of these settlers. It was natural for them to follow the same occupation in America that they had followed in Europe.

Impossibility of an Industrial Monopoly. The economic or industrial strength of a nation at that time depended largely upon individual skill, and not upon an organization of men united by machinery as we find it to-day. A factory then consisted of a group of men and women working with the hands. To-day it consists of a group of men and women manipulating machinery. Then it was impossible to have an industrial monopoly unless a nation could gather together all the skilled 
workmen of the world. To-day it is possible, for by the aid of machinery the product is greatly increased, and business organizations can, through the aid of machinery, control the entire manufactured products of the world. Then the skill of the hand was so limited that every family had to engage in manufacturing the necessities of the home. From the arctic to the torrid zones wool and flax and leather were easily obtained, and the strength of each colony in America, as well as of each nation in the world, depended absolutely upon what each family could make out of the raw material produced around the home. Then as a rule shipping raw material from one nation to be made into finished products by another was too costly; for the hand was slow and the output was too limited to produce the needs of the two.

There could be, therefore, no such thing at the beginning of the eighteenth century as a monopoly of food and clothing. Since this was economically impossible England, like other European nations, tried to produce one through political means. Laws were passed in England that tended to discourage all manufacturing in the colonies. But the spinners and weavers from the parent countries increased their skill and efficiency in spite of prohibitive laws. For all manufacturing, like the production of the raw material, was an individual affair; it was a domestic affair. Individual excellence, not accumulation of capital and the manipulation of delicate machinery, determined the wealth of the colonists. 
Impossibility of a Cotton Monopoly. The cotton industry in America was a failure so far as its use in making clothes was concerned. The colonists could not separate the seed from the lint in sufficient quantities, and the cotton produced was of such a nature that they could not make a strong thread of it. The best cotton was imported from the West Indies and Brazil for home use. No section of America could have a monopoly of it; for Pennsylvania and Delaware could raise to advantage almost as much as South Carolina and Georgia, and they were producing it when the Revolution closed. In no section of the country could the farmer use more than a few pounds. One hundred pounds in the lint would have been an enormous amount for any farmer to produce. It could be used to some extent by mixing it with other fibers; but wool and flax were the chief fibers for cloth making. The colonists were making fast strides toward efficiency in these industries, and the same efficiency was transferred to cotton fabrics when the age of invention appeared.

The skill of Europe in weaving and spinning was just becoming equal to that of India, Egypt, and Palestine of a thousand years before. Many of the same methods were in use. There were few inventions. The whole process depended upon hand skill, and this was becoming a factor in America.

The Hand Loom of Our Grandmothers. The art by which threads or yarns of any substance are made into cloth is called weaving. This is perhaps 
the most ancient of the manufacturing arts, for clothing has always been, next to food, the first necessity of civilized man.

The good weavers of colonial days used a loom that was worked by hand, the principle of which was originally used by the Hindus of India long before the people of Europe knew there was such a plant as cotton, and before they ever dreamed of

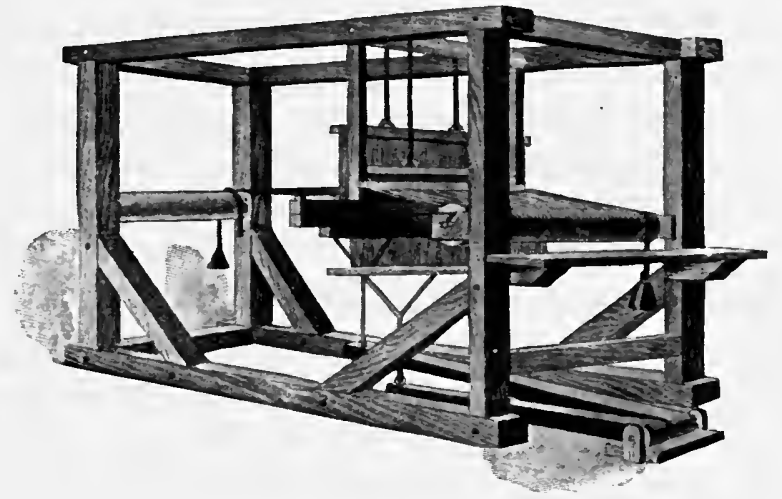

An old-time hand loom.

such a continent as America. This hand loom has even come down to our own day with very little change. It is about the only machine that we have inherited from those very ancient days, almost in its original form. How does this loom look to-day?

It is a frame of four square timber posts arranged about as far apart as the posts of a tall, old-time, four-post bedstead. The back posts are connected by a yard beam about six inches in 
diameter; the front posts are connected by a beam nearly a foot in diameter, and it is called the cloth beam, because the cloth as it is woven is wound around it. The warp threads running parallel and very close together are wound around the yard beam and fastened to the cloth beam at the front of

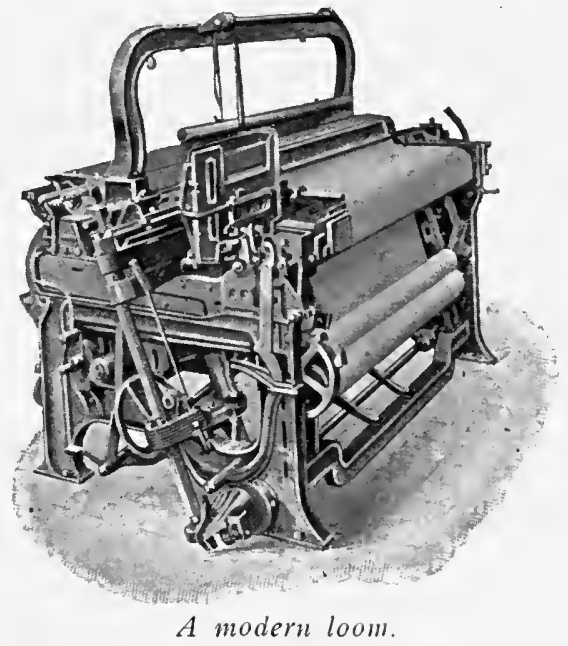

the loom, where they form a part of the cloth. This warp holds the frame for the cloth. . The cross thread, which is called the woof, must pass under each alternate warp thread. This is done easily by raising every other thread by means of a saddle or treadle, which is merely two rows of cords or wires suspended from two frames worked by pulleys. Each thread of warp passes through the loop of a cord or wire, and so adjusted that when one is raised every alternate warp thread is lowered. 
The woof is wound around a quill so fixed as to revolve within the shuttle, which is now passed between the two sets of threads. The first frame is then lowered and the second one raised, and the shuttle passes back through the two sets of threads. There is another frame hanging loose from the beams above the warp. Its wires separate the warp, and when the shuttle passes through it is pulled hard against the woof. This drives the thread into place.

"The web enwraps the beam, the reed divides, While through the widening space the shuttle glides, Which their swift hands receive, then poised with lead The swinging weight strikes close the inserted thread."

The process of weaving is seen best in the common mode of darning, when a set of lengthwise threads is first fastened firmly and then crossed by other threads, which are woven in and out by taking up one thread and leaving one.

This is the work of the hand loom that our grandmothers used and that is still in use to-day in a few homes. Its principle was in use by the Hindus when the Europeans first saw cotton "growing on trees," but they did not pass the shuttle back and forth as easily as our grandmothers did. George Washington was a small boy when one John Kay of England improved the shuttle so that weavers could drive it back and forth by means of a handle placed conveniently beside their stools. This simple improvement made it possible to weave very wide cloth. $U_{p}$ to this time spinners 
could supply the weavers with thread as fast as they could use it. But with this invention the speed of weaving was doubled, and the spinners could not supply the necessary thread.

The Distaff and the Spindle. The early Hindus spun by means of the distaff and spindle. The spinner in Europe and America, usually a girl, held under her arm a bunch of carded wool, flax, or cot-

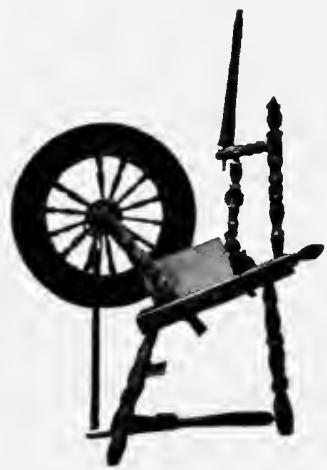

Early flax wheel.

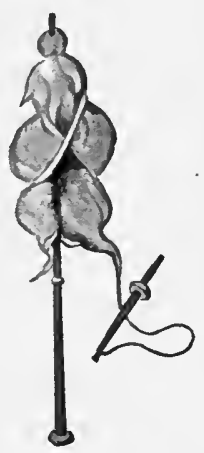

Distaff and spindle.

ton fixed to the distaff. Then with her fingers she twisted the fiber, drawing it out at the same time, and attached it to the notch in the end of a short, slender stick, called the spindle, which hung down freely, whirling rapidly as it went down. She fed out the fiber gradually and spun it in this manner as the spindle whirled around rapidly. The woolen or linen threads could be very well spun in this manner, but the cotton thread was too weak; it would break-hence the difficulty. Ancient spinners of India, in spinning the finest threads, which 
have always puzzled the Europeans, fixed the spirs dle in a shell so as to revolve freely in an upright position. In this way they could spin the cotton raised in the tropics, which was of a long fiber; but in America the fiber was short, much coarser, and more difficult to spin.

For many centuries the distaff and the spindle were in use, and were employed by women as they went about the home, or on their way to market. A picture of the spinners in the seventeenth century is given in these lines:

\section{"And many still adhere}

To th' ancient distaff, at the bosom fixed, Casting the whirling spindle as they walk; At home or in the sheepfold or the mart, Alike the work proceeds. This method still Norvicum favors and the Iconian towns; It yields their airy stuffs an apter thread."

Those who have seen the flax wheel will recognize the close similarity to the ancient distaff and spindle. Here is the distaff with the flax and the spindle, which revolves in a horizontal position instead of the vertical position of the ancient Hindus. Here the spindle is revolved by the wheel, which is worked with a treadle, but the flax is pulled out with the fingers and kept in position as in ancient days.

The Spinning Wheel. The large spinning wheel was used for spinning wool, before the days of cotton, and when the value of cotton was understood the cotton thread was spun on this wheel. It was invented by the Germans about seventy-five years 
before the settlement was made at Jamestown, yet the same principle was used by the Hindus when the world was in its infancy.

We have told in another chapter how cotton was prepared for spinning. After it had undergone this treatment it was carded, that is, a small handful of prepared cotton was caught on the stiff wires and combed out, after which it was rolled into small, loose rolls about the size of a tallow candle. Then it was ready for spinning.

The spinner revolved the wheel with her right hand. This gave a very rapid motion to the spindle. Then she caught the end of one of the loose rolls to the end of the spindle. As the roll twisted, it was drawn out several times its original length. By repeating this process the roll was spun into a tight, round thread. A second roll was then touched to the unspun end of the thread, which, revolving, caught the end of the roll that was now spun like the former roll. This process was repeated until many rolls were spun into one thread several yards in length.

Increasing Interest in Cloth Making. A description of spinning and weaving is given here that we may. understand how our ancestors made their own cloths and how individual excellence counted for more than the accumulation of capital. Each family had a spinning wheel, and numbers of families had the loom. It was almost a disgrace for a girl, whether rich or poor, not to know how to spin, and boys were apprenticed to weavers to learn the 
art of weaving. A professional weaver had several of these looms and employed many men in operating them. This was the first factory. Girls were taught everywhere to spin, and the thread was either bought by the weavers or was woven into cloth on shares.

When the improvement in the loom mentioned above was made it was difficult for women and girls to spin thread enough for the weavers. One man would take a day off at the beginning of the week and buy up all the thread in the neighborhood. Azbout the time of the Revolutionary War it was no uncommon thing for a weaver to walk several miles in the morning, calling on many spinners, before he could collect enough thread, or woof as it was called, to serve him for the day.

George Eliot's Weaver. In George Eliot's Silas Marner, the weaver of Ravenloe, an interesting story is told of the English weaver seeking his thread:

"In the days when the spinning wheels hummed busily in the farm houses-and even great ladies, clothed in silk and thread lace, had their toy spinning wheels of polished oak-there might be seen, in districts far away among the lanes, or deep in the bosom of the hills, certain pallid undersized men, who, by the side of the brawny country folk, looked like the remnants of a disinherited race. The shepherd's dog barked fiercely when one of these alien-looking men appeared on the upland, dark against the early winter sunset; for what dog 
Development of Skilled Workmen in America '63

likes a figure bent under a heavy bag?-and these pale men barely stirred abroad without that myste-

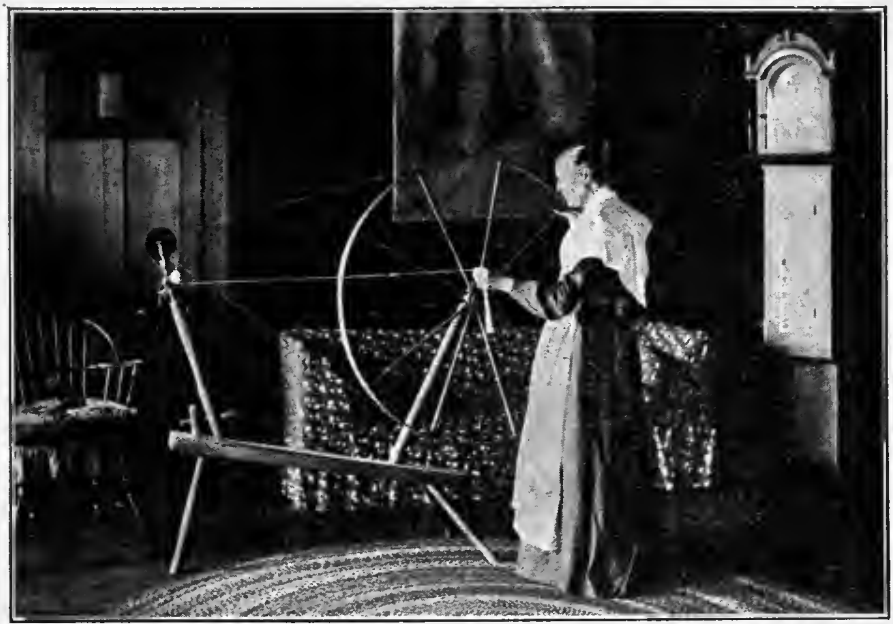

From Dodge's State Geography of New England Spinning by hand in a colonial home.

rious burden. The shepherd himself, though he had good reason to believe that the bag held nothing but flaxen thread, or else the long rolls of strong linen spun from that thread, was not quite sure that this trade of weaving, indispensable though it was, could be carried on entirely without the help of the Evil One."

Activity in the Colonies. This is a gloomy description of the English weaver. In many places, especially in America, the weaver was a very important person. Different colonies passed laws encouraging both weaving and spinning, and a good weaver was held in the highest esteem. He 
frequently offered prizes to young girls in the community who would spin the greatest amount of thread in a week. The prize was usually enough cloth to make a dress. Every farmhouse was a factory in miniature, where women spun. And as the industry increased mills were established for the purpose of dyeing, weaving, and fulling, that is, cleansing and pressing and thickening the cloth. A weaving mill was a place where several hand looms operated by as many men were in service. In the ancient city of Thebes we find this same kind of factory many centuries before the Christian Era.

It is a little difficult to-day to get a picture of the life of the people in the middle of the eighteenth century, for occupations have changed, bringing different manners and customs. This change is due in a very large measure to many inventions and the use of machinery in producing the three great necessities of life.

The activity in the colonies was individual, yet it was general. Colonists were approaching economic independence. They encouraged spinners and weavers in direct violation of the instructions from England. Although there had been great improvement in home manufacturing they were yet unable to make that beautiful "brocade print, very remarkable," with large red roses and blue and yellow flowers with green leaves and stems on a dark background, but they were promising to become the rivals of English manufacturers. 
They studied the art of dyeing. They learned to use the various flowers growing on the farm. The goldenrod mixed with indigo and alum made a beautiful green. A piece of pokeberry boiled with alum made crimson, and the juice of the iris gave purple. Indigo was cultivated throughout the South, and not only was it used on the plantations for blue coloring but was also shipped to England and to other countries. The bark of the sassafras, when mixed with copperas, was used for dyeing yellow, the leaves of the gallberry bush made a good black, and the horse laurel gave yellow. The bark of the "Black Jack" oak mixed with red maple bark also gave black. The walnut, the red oak, the hickory bark, all contributed to the colors of the colonists.

Notwithstanding all this progress in dyeing, the colonists were unable to reproduce the fine goods that were so highly prized. They simply could not be made out of the cotton raised in the South. The beautiful fabrics shipped from Asia and Europe through London to the people of America were very costly, and large sums of money were spent every year for them by the colonists.

How England discouraged this Activity. It is a very modern idea that a dependent territory, such as the colonies of the middle of the eighteenth century were, may be encouraged to produce all the necessities of life. Therefore England's attitude toward the colonies, in keeping with the spirit of the age, encouraged the production of food but only of 
the raw material for clothing and shelter. Even in the production of food the surplus must go to the mother country.

"You say, sir, that the people are propagating large quantities of flax and cotton, and they are provided with weavers, who have already wove several large pieces of cloth of a useful sort, whereof they sold divers, and some they made use of in their own families. . . They must expect no encouragement for setting up manufactures which may interfere with those of England."

These were the instructions from England to the governor of Georgia, and he was advised to discourage all manufacturing on the grounds that it might occasion "complaints here." England wanted all the American cotton.

Having the raw material at hand, the people, far removed from the mother country, gave little heed to the restrictive laws that grew more severe from decade to decade. When the spinners and weavers in America went from the coarse goods to the finer fabrics, rivaling to some extent the finer fabrics of England, a cry went up from the manufacturers in England and the pressure became heavier and heavier, and affected every colony from Massachusetts to Georgia.

Spinning and weaving schools, nevertheless, were established. The weavers of New England began importing cotton from the West Indies, for they could use the long fiber better than the short fiber of the colonies. Handmade goods reached a high 
stage of perfection, especially in Europe. The demands for them everywhere called for machinery, and improved machinery. Europe was spending large sums for fine clothing, and the wealthier classes of America imitated the styles set in London and bought all of their finer clothing from England.

How it produced a Revolution. When the Revolutionary War came on, and just before, a great outcry was raised in America against such luxury. A movement was started in New England and in the South to promote economy and household industry. Spinning matches were organized. Societies for encouraging home manufacture were formed, notwithstanding the instructions from England. Ministers preached to the faithful women the necessity of economy. Spinning and weaving schools were established. Weaving parties called the young people together, and while they talked and laughed some were carding cotton, some were spinning, and some were reeling.

All this activity had a tendency to increase the production of cotton, for it could be mixed with wool and flax to much advantage, and the objection raised by England to the manufacture of it, while it was not heeded, made another grievance against the mother country and helped to hasten the Revolution. The first step toward political independence is economic independence, and if the colonies in 1775 had been as dependent on England for food, clothing, and shelter as in the few 


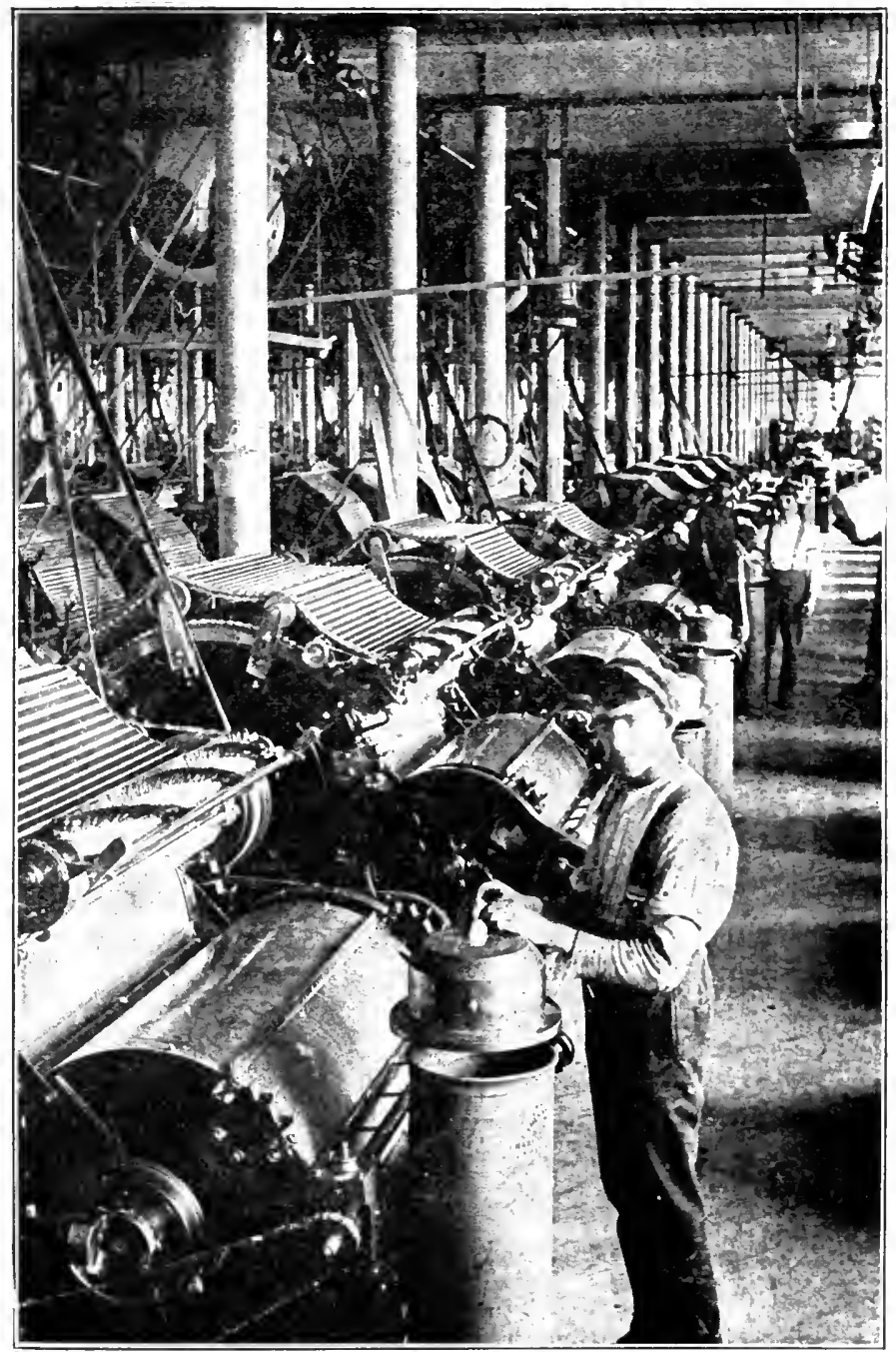

Copyright by Underwood \& Underwood, N. Y.

Carding room in a great cotton factory at Columbia, South Carolina. 
years just after the first settlements, there would have been no Revolutionary War, for there would have been but little if any independent political thinking.

Spinning and weaving increased rapidly, and there was little cotton to spare for the English weavers. In 1753 Carolina did send a few pounds to London; in 1764 eight bags were sent to Liverpool ; and in I770, just before the Revolution, three
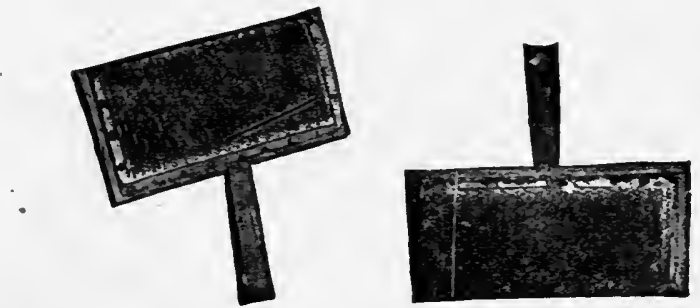

A pair of old-time cotton cards. Compare with the modern carding machines shown on opposite page.

bales went out from New York, ten from Charleston, four from Virginia, and three barrels from North Carolina. It is probable that this from North Carolina was shipped in the seed. But in the last days of our colonial life it was clear that the hand alone was not sufficient in manipulating the cotton fiber. The world was demanding more than the hand, working alone, could produce.

The great Revolutionary War now came on. The people of America were fighting for independence. They wanted the right to make their own clothes, to exchange where they pleased their own surplus foodstuff, to sell where they pleased. 
and to buy where they pleased. It is not the purpose here to state all the causes of this great war, but the colonists objected to the taxes and the interference with their daily life. They were approaching economic independence; and for seven years they fought under George Washington for complete separation from England. They won, and a new political era began. 


\section{CHAPTER V}

How Skill created a Demand for Cotton

How the War encouraged Manufacturing. During the Revolutionary War the people of America were unable to buy from England or from any other country except at the risk of very great danger, therefore they were compelled to rely on themselves for all their manufactured goods. This greatly stimulated both the cultivation of cotton and the manufacture of cotton goods, and increased the demand for wool and linen. Societies were organized for the purpose of encouraging home manufacturing; women refused to wear the silk imported from England; congregations of men and women would come together and, while they spun and wove and carded, the minister preached to them the necessity of economy in the home. Every farmer's daughter was taught not only to weave as well as to spin, but to weave better and spin finer. The sound of the loom and the buzz of the spinning wheel in every farmer's home told of the industry. Men and boys who were not in the army learned the art. Legislators encouraged it, and requested families to supply enough clothing for the soldiers in the fields. Vast quantities of homespun cloth were made on the plantations. Hundreds of yards 
were made annually at Mount Vernon, the home of Washington, and it is told of Martha Washington "that she always carefully dyed all her worn silk gowns and silk scraps to a desired shade. After ravelling them with care, she wound them on bobbins, and had them woven into chair and cushion covers. To a group of visitors she one time displayed a dress of red and white striped material. of which the white stripes were cotton and the red stripes were ravelled chair covers and silk from the General's worn out stockings." This dress in all probability was as pretty as that stolen from Mistress Benjamin Franklin.

This gives a lesson of the industry and the economy of the colonists, for even the wife of the great General Washington set an illustrious example. This activity was general. It was found in the New England village and on the Southern plantation. Everywhere there was activity.

Interest in Spinning. The interest which the young women of America began to take in spinning just after the Revolutionary War was very great. On hearing of the adoption of the Constitution in I 789 , between thirty and forty young ladies met at the house of a certain minister, taking their wheels with them, and spent the day in spinning. At the close of the day a prize was given to the best spinners, after which the minister delivered a profitable discourse. A favorite text for such occasions was taken from Exodus xxxv, 25:

"And all the women that were wise hearted did 
spin with their hands, and brought that which they had spun, both of blue, and of purple, and of scarlet, and of fine linen."

It is recorded again that forty-three ladies met on a certain day in the State House of East Greenwich, Rhode. Island, and spent the day in spinning. While they spun, the young gentlemen waited on them and served wine and cake.

It was during the Revolution that a new invention for spinning cotton was produced in England, which we will tell about in another chapter. It - taught the people how to spin the finest thread from cotton with great ease and rapidity. With it cotton could be spun into a thread sufficiently fine and strong for the warp in weaving. This was the beginning of the great industrial revolution.

How Homemade Goods were encouraged. In every city, from Boston to Charleston, societies for the encouragement of manufactures sprang up immediately, for this machine soon found its way to America. The seaport towns were urged to join in a movement to check importation of clothes from abroad, in order that our own people might be encouraged to manufacture their own goods. The members of the society formed in Delaware pledged themselves to appear on the first of January of each year clothed in homemade goods. A factory was built in Philadelphia, and was equipped at great cost with machines for carding and spinning cotton. This enterprise had a great tendency to encourage cotton culture in the South. 
Young society women were no longer ashamed to wear home-manufactured clothes, and they became proficient in the art of spinning. Young men no longer thought it a disgrace to be seen in homespun stockings that came above the knees, and in homemade jeans. Politicians boasted of the fact that they cared only for home-manufactured goods, and held up to ridicule those who still bought their goods in London. George Washington stood forth to take the oath of office, as the first President of the United States, clad from head to foot in garments the material for which was made in America, a large part being made at Mount Vernon; and John Adams, on his way to take the oath as VicePresident, was presented by the society of Hartford with a roll of cloth made from the Hartford looms.

But where was the fiber to come from? Wool growing became a great industry; farmers increased the size of their flax patches; the cotton fields of the South were likewise increasing in area; but the seed adhered too closely to the fiber to encourage the cultivation of cotton on a large scale. The invention that had just appeared made it possible to spin a better thread; but how were they to get the lint? Let us see how cotton was cultivated at this time.

How Cotton was cultivated at the End of the War. The year after the war closed a traveler going through the South saw the cotton growing, and he tells an interesting story of the method of cultivation. Here is his description of a cotton field: 
"Cotton is the most useful production of this country, and all the Southern provinces.

"It is cultivated in this manner. About eight of the seeds, which somewhat resembles those of a sun-flower, are planted together in small hills about two feet asunder; for this purpose rich gravelly soils are by far the most valuable. That number of seeds are put in the ground because so many of them are so faulty that it is very seldom more than two or three of all the eight or nine vegetate.

"In about ten days it is seen above ground and then it resembles the leaf of the kidney-bean. As the summer advances it must be weeded, worked, and the earth thrown towards the roots of the plant.

"As it grows it shoots forth into eight, ten, twenty or more different branches; and when ripe is about twelve or eighteen inches above the ground. The pod then is about the size of a black walnut, of a dark color, round and pointed at the extremity. When perfectly ripe this pod bursts itself with an audible crack, and the cotton expands itself out of four or five different cells, each of which contains a seed surrounded by a quantity of fine cotton of snowy whiteness.

"It then has the appearance, at a distance, of a large and elegant white rose of the most beautiful and perfect whiteness. At this time it is gathered, which is about the fall of the leaf, that is the latter end of October.

"Little negroes and useless hands are employed every night in picking the seeds from the cotton, 
which is a very tedious and tiresome operation.

"Cotton in this state is worth three pence [six cents] sterling per pound including the seed, and when they are picked from it, it sells for a shilling sterling [about twenty-five cents] per pound.

"An acre of land in the culture of cotton contains about seven thousand five hundred hills, and on an average would produce perhaps five hundred pounds weight.

"One hand or slave might cultivate five acres, which, by selling it in the seed, would bring about thirty-two pounds sterling. But it would be impossible for such a quantity of cotton to be picked from the seed by the hands a planter could spare.

"There is a more expeditious method of picking cotton called a gin, which, however, breaks many of the seeds amongst the cotton, and renders it of less value than what is picked by hand."

The Ancient Gin in Use. The gin that the traveler refers to is the most ancient of all the machines used for separating cotton seed from the lint. It was used by the Chinese and the people of India centuries ago, and was called the churka. It was also used in Italy and other countries of southern Europe. A traveler passing through the South in I722 saw it in use, but this particular machine was made in the South. A few of these old gins or churkas are still preserved.

The gin consisted of two wooden rollers, somewhat like the modern clothes wringer, fixed in a frame and revolving in contact. The cotton was 
drawn between two rollers, which were so close together that the seed could not well come through. Smaller seeds coming through, however, were broken and crushed in the lint, as the traveler says, and did much damage to it.

This gin could be used to advantage if the cotton was of the long-staple variety and the seed did not cling so tightly to the lint; but the cotton of the South was chiefly of the short-staple variety. The gins in existence were therefore of little value, and planters preferred to pick the seed out by hand. It is no wonder that an acre was all a good planter could care for.

Dependence of America upon Europe. In the same year that the traveler, mentioned above, visited the cotton fields of the South, eight bags of cotton were shipped to Liverpool; but these were seized by English officers on the ground that it was a fraudulent importation. They said they did not believe that so much cotton could be produced in the United States. These officials were evidently stating a falsehood, and seeking an excuse for taking the cotton. However, before the Revolutionary War a great deal more cotton than this was shipped to Liverpool, and English soldiers under Cornwallis saw in the South many patches of cotton under cultivation. But this merely goes to show how dependent the colonies were upon the mother country. They had gained political independence, but not their industrial independence. Political independence opened the way, but 
to gain industrial independence was a longer and more tedious process.

The colonies had been growing toward economic independence since the earliest days. But American workmen had to compete with the skilled workmen of Europe; and when articles produced in America were not equal to those that were produced in Europe, America lost by comparison. Enlightened people in one section of the world seek to appear like enlightened people in other sections of the world. It was this instinctive tendency that made Europe dependent upon Asia; and it was this same tendency that made America dependent upon Europe. England, Spain, and France were more advanced in the arts of living, and America took her lessons from these nations. Therefore the trade of these countries with the United States was an important factor in American politics, and finally produced a second war with England, which was really a revolution for economic or industrial independence.

The Progress of Labor. Immediately after the Revolution societies were formed, both in the North and in the South, for encouraging manufacturing. Planters in the South experimented with seed and took lessons in seed selection. In New England and the East it was really thought that a score of commodities might be manufactured cheaper and better than those of the old country. Away down South, according to Thomas Jefferson, the states "made a great deal of cotton" and 
the goods manufactured by themselves were "as well manufactured as the calicoes of Europe."

In I786, 600 pounds of cotton were shipped to Liverpool; the following year, more than 16,000 pounds were exported; and in the year that George Washington was inaugurated President, 127,500 pounds were exported.

Development was evident and adjustments were gradual, and America through cotton culture was entering upon a career as a world power. The first symptoms of this new spirit were expressed by Richard Leake of Savannah in 1788 , in a letter to Colonel Thomas Proctor of Philadelphia.

"I have been this year an adventurer (and the first that has attempted it on a large scale) in introducing a new staple for the planting interests - the article of cotton-samples of which I beg leave now to send you and request you will lay them before the Philadelphia Society for Encouraging Manufacturers that the quality may be inspected. Several here, as well as in North Carolina, have followed me and tried this experiment, and it is likely to answer our most sanguine expectations. I shall raise about five thousand pounds in the seed from eight acres of land, and the next year I intend to plant about fifty to one hundred acres if suitable encouragement is given. The principal difficulty that arises to $u$ is the cleansing it from the seed, which I am told they do with great dexterity and ease in Philadelphia with gins or machines made for the purpose. 
I am told they make those that will clean thirty to forty pounds clean cotton in a day and upon very simple construction."

The new government became interested in this new industry that was developing so fast. In 1789 Nathaniel Macon of North Carolina, then a member of Congress, proposed a tariff on cotton to protect the Southern States against the West Indies and Brazil, but the bill was defeated. The South's greatest competitors at this time were the West Indies and Brazil. In fact, these were the real cotton countries of America.

The Age of Invention. The skill of the hand, working alone, has distinct limitations, and the production of raw material, whether food, clothing, or shelter, is but one step toward independence. It has always been the case, however, that the production of raw material, like cotton for instance, can easily exceed the capacity of the skilled hand when the hand works alone. Cotton could be produced in abundance, but the hand alone was unable to keep pace in separating the seed from the lint, or spinning the fiber into thread, or weaving the thread into cloth. Corn could be produced in abundance, but the hand alone was unable to keep pace in grinding it in the old primitive mortars into foodstuff. The forests had an inexhaustible supply of building material, but the hand alone could never be able to exhaust the supply. Before the new nation was a year old a patent law was passed in America in I790 securing to the 
inventor of "any useful art, manufacture, engine, machine, or device, or any improvement therein not before known or used" exclusive monopoly. One little machine that could equal the skill of a thousand men while employing the labor of ten would draw into service a power in nature that the world had not dreamed of. The age of invention was at hand, and when it came the world was made over in a few years. All the arts of life procuring food, clothing, and shelter, the entire appearance of society, even the thoughts of men-all began to enter new channels, and the man with a great idea created a monopoly and laid tribute on the rest of the world. Individual excellence now became a world factor, and isolated skill was passed by with merely a word of comment. Cotton now became king of clothing, while the commerce of the world, and the politics of America, fell under the influence of the cotton plantations of the Southern States.

The Statesman and the Inventor. Our histories dwell at length on the grievances of the American colonies and the methods used by England to hinder our manufacturing and to stop our trade with the world. Many chapters are written on the heroic services of the Revolutionary patriots. Such writers tell of the patriotism of Samuel Adams of Massachusetts and Patrick Henry of Virginia. They honor George Washington for his great achievements, and Thomas Jefferson and Benjamin Franklin for their great devotion; and 
the time should never come when the deeds of these and other heroic men will no longer be recorded in the histories of the world, for they helped to separate America from England, changed the destiny of a people, and gave new meaning to liberty.

Yet while their deeds were being recorded another group of men were changing the manners and customs of the world, opening new occupations to men and women, giving direction to the politics of the world, bringing continents closer together, giving a new basis to aristocracy and personal worth, making America supreme in the industrial world, and the cotton of the South king of the fabrics of the world. These men were Richard Arkwright, the inventor of the spinning frame; Eli Whitney, the inventor of the cotton gin; and James Watt, the inventor of the steam engine. In the next chapter we shall consider the works of these men, and the influence of their inventions on the world. 


\section{CHAPTER VI}

\section{How Cotton became King of Clothing}

The World is made over. Before the age of invention, cotton was cultivated by hand, the seed were removed by hand, and the cotton was woven into cloth by hand. This slow process made each family a manufacturer. The kind of clothing therefore was limited; the varieties of cotton were limited; the grade of goods was limited; the amount of cotton produced was limited; the furnishings in the home were limited, and the variety of foods was limited. The individual was economically independent; yet he was not a part of the world's force. His strength ended at the boundary line of his home; and the world moved slowly. He contributed little to the world's progress and the world contributed little to his.

To-day the whole world contributes to the material wants of a single individual. Food and clothing come from the four corners of the earth, and every enlightened man is a citizen of the world. How have these changes come to pass? And while the world was being made over, how did cotton become the king of clothing? This story involves many inventions, but is principally concerned with three. 
Richard Arkwright. It was Richard Arkwright, a very poor man, who invented the machine for spinning cotton. He was born in Lancashire, England, the same year that George Washington was born. Richard was the thirteenth and youngest son of his parents, who were so poor that they could not send him to school. The greatest question of his parents was how to provide food, clothing, and shelter for so large a family. They therefore apprenticed him early to a barber, since this was the occupation chosen for Richard to follow, and for a number of years he toiled in a cellar, serving his customers as best he could.

He became a first-rate barber, and followed this occupation until he was thirty years of age. Although his parents were too poor to send him to school he had what thousands of youths do not possess to-day - a great desire to study-and since his parents could not employ a teacher for him he bought his own books and became his own teacher.

His first success came after he discovered a secret method of dyeing hair. His profits in this line influenced his after life, for he gave up the barber's trade and became a dealer in hair. He traveled up and down the country, collecting his material from barbers, women, and girls who had hair for sale. He made a specialty of dressing and dyeing it to suit the taste of people.

The greatest question for manufacturers was how to get a sufficient amount of cotton thread. The old spinning wheel was too slow. Many 
people had attempted to invent some machine that would increase the output. It is said that when Arkwright was twenty-one years old, a man by the name of Earnshaw invented a machine to spin and reel cotton at one operation; but it is said also that he destroyed it that it might not deprive the poor spinners of bread. For at this time many families, both in England and America, were dependent upon this labor for a living.

His love for mechanics soon called Arkwright away from all other occupations, and at the age of thirty-five he gave himself up entirely to the study of inventions for spinning cotton; and two years later, in 1769 , he obtained his first patent for spinning with rollers.

The Spinning Frame. The spinning frame was constructed to spin a vast number of threads of any degree of fineness and hardness, leaving man merely to feed the machine with cotton and to join the threads when they happened to break. This machine consisted of two pairs of rollers turned by machinery. The lower roller of each pair was furrowed or fluted and the upper one was covered with leather. The cotton as it passed between the first pair of rollers had the form of a thick but very soft cord, resembling the soft roll. that our grandmothers carded; this is called roving, and is about the size of a tallow cardle. Those who have seen cotton carded by hand will understand the size of this first cord that came through the rollers. As it passed through the first pair of 
rollers it was received by the second pair, revolving many times faster than the first. This necessarily drew the cotton out many times smaller than when delivered from the first roller. In I77 I a mill was built, and this machine, run by water power, was used with success. It received the name waterframe, and the thread was called water-twist, because of the power used.

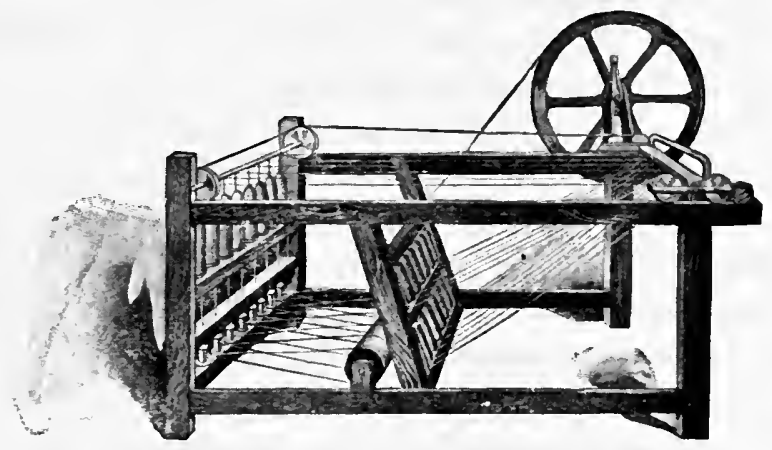

The spinning jenny.

The Spinning Jenny. Notwithstanding the ease with which the thread could be spun, it did not make the strong thread desired. A few years before Arkwright invented his spinning frame, James Hargreaves, another Lancashire weaver and carpenter, invented a novel spinning machine known as the jenny (probably named after his daughter, who helped in the spinning.)

It was a very simple machine, consisting of a rectangular frame mounted on four posts. The spindles stood in a row between the rear posts, and were turned rapidly by a wheel which was at 


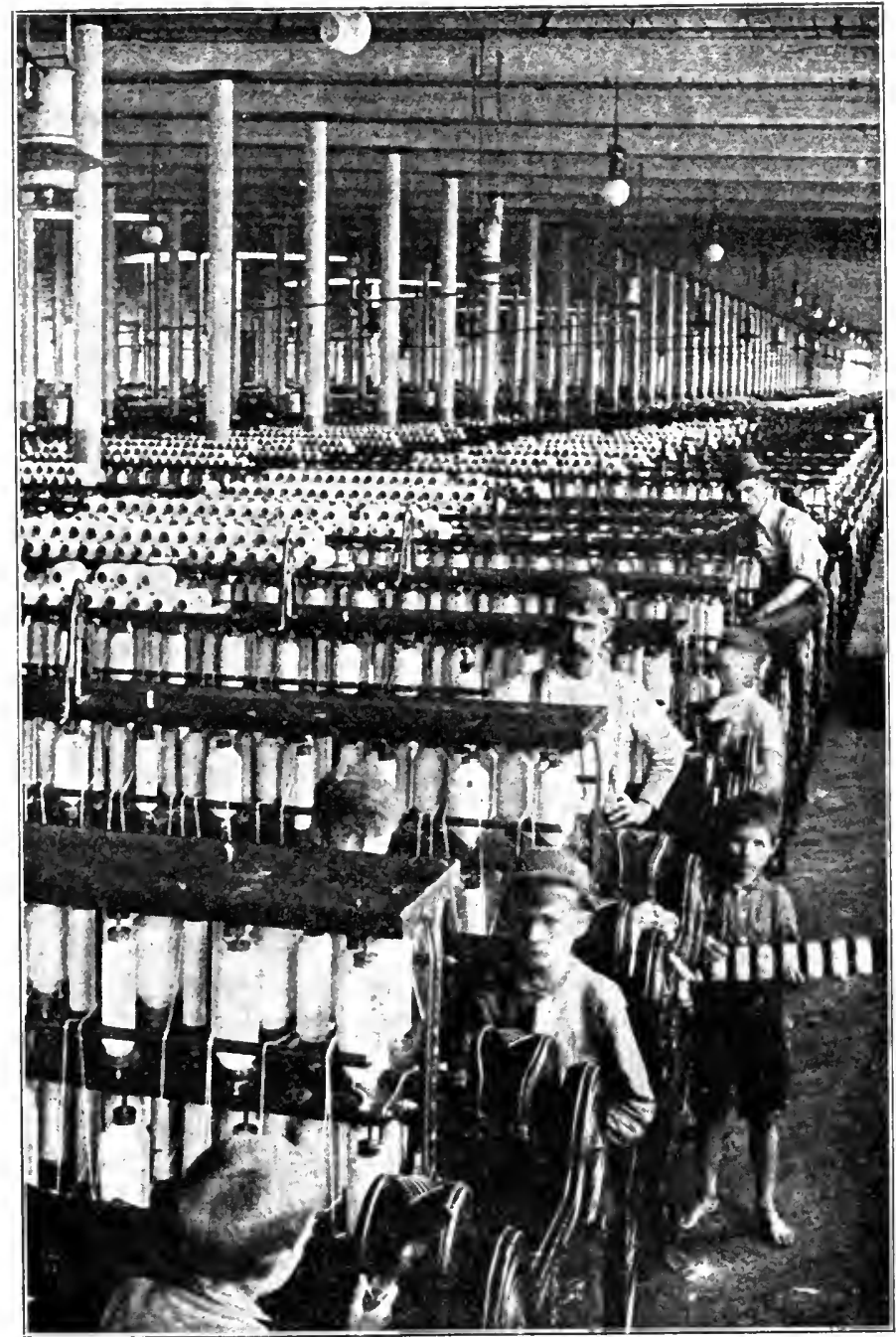

Copyright by Underwood \& Underwood, N. Y.

In the spinning room of a great mill in South Carolina. Here are 104,000 spindles. 
first operated by hand. In front of them was a frame moving back and forth, through which the threads, gathered from the prepared cotton or rovings, were attached to the spindles. By moving the frame back and forth the thread was drawn out as it was by hand when spun by the wheel. The principle here is about the same as that employed in the old method of spinning, except eight or nine threads were spun as easily and as quickly as one was spun before.

Arkwright's spinning frame needed the assistance of this spinning jenny in order to produce the strong, fine thread needed by the weaver. Another weaver, named Compton, made the combination, and the new machine was called the "mule."

How this Invention was received. From this time on goods could be made entirely of cotton, and as fine and as strong as it was needed.

Arkwright had great trouble in introducing his machine. Manufacturers at first refused to use his yarns. Spinners became angry, and attempts were made to murder him, for they were afraid that his machine would take away their occupation. At last he overcame all obstacles, for the machine was too valuable to be ignored. From the day he brought it out until his death he was constantly astonishing the manufacturing world by a series of inventions and improvements out of which "have grown the largest manufacture, the largest trade, some of the largest cities, the largest revenue, and the largest national prosperity of the world." 
His inventions, it is said, enable one man and four children to spin as much cotton as was spun by six hundred women and girls more than a century ago; and one half the total population of America to-day would be unable, working day and night, to do by hand the work that is now done in England alone by the Arkwright machine.

\section{Another Invention was needed. Two years} before George Washington became. President, people learned how to run the loom with water power. This made it easy to spin and weave cotton goods in great quantities, if cotton could be obtained, and these inventions naturally made a much greater demand for cotton. For the first time now in the history of the world, pure cotton goods could be manufactured by the inhabitants of Europe and America. Efforts were therefore made to cultivate cotton on a much larger scale. It was learned that the Southern States could supply the market. But no one knew how to separate the seed quickly and satisfactorily from the lint, except to pick them apart; and we have already told how slow was this process. The old machine with two rollers that pushed out the larger and mashed up the smaller seeds was very unsatisfactory, for it damaged the cotton and made it hard to spin. Just one more invention was needed to make the South the greatest cotton country in the world, and this machine was the work of Eli Whitney.

When Richard Arkwright was perfecting his 
spinning frame, Eli Whitney was playing in his father's workshop and developing the mechanical genius that was to give the world another great invention. The spinning frame gave the thread, water power ran the looms, but how were they to get the cotton separated from the seed?

The Story of Eli Whitney. Eli Whitney was born December, 1765, in Westboro, Massachusetts, when the colonists were already making strides toward the Revolutionary War. His mother was an invalid, and died while he was a small child. His father had a workshop near the house, and before he was ten years old Eli could use every tool with an ease that would have pleased a much older workman. Before he was twelve he had made a violin, and the people of the neighborhood knew that if their violins should break or get out of order, Eli could mend them. By the time he was sixteen he had become a nail maker, and was known to be the best in all that neighborhood. He was an excellent workman. He made pins for women's bonnets, and walking sticks for men. In this way he made a good deal of money in the afternoons and at nights, while he attended school.

When Eli was thirteen years old his father married again. His stepmother showed him some very fine dinner knives that were made in England. One of the knives was soon broken. Eli took the broken knife to his shop and soon made another so much like it that his stepmother could hardly tell the difference. 
During the Revolutionary War young Whitney became a nail maker, and this occupation was very profitable. In those days the people of America had to buy most of the manufactured goods from England. We have learned ìn a previous chapter how England discouraged all mảnufacturing in the colonies, and when the war made it impossible to buy from England every one was glad to get the products of the young nail maker.

Eli worked in his father's shop until he was nineteen years old. He had always taken a great interest in his books, so when he decided to go to school his father and his neighbors said it was useless, for he was already making a good living. $\mathrm{He}$ nevertheless left home and began to make his own money so that he might attend college. He taught school, worked in shops and on farms, and welcomed any task whereby he could earn money for his education. When he was twenty-four he entered Yale College.

Eli found that he could not get board in college and live like the other students. They spent too much money. He therefore secured board in "a private family near the college. Here he did some carpentering, and by occasional odd jobs and by working during vacations he was able to remain in college until he completed his course.

The young college graduate wished to become a lawyer, but before he could take the law course it was necessary for him to make some more money. As many young men do to-day, he decided to teach 
school for a while, and an opportunity was soon presented to him. He was offered a position in a private school in Georgia. This offer pleased him very much, for he had never been in the South. Since he had had some experience in teaching, he accepted the position at once.

His Visit to the Land of Cotton. In those days there were no railroads, so the young teacher went by boat from New York to Savannah, Georgia. On his trip he met Mrs. Nathanael Greene, the widow of General Nathanael Greene of the Revo'uicionary War, who is famous in history for his fight with Lord Cornwallis at Guilford Courthouse and for the able manner in which he organized the Southern troops. Mrs. Greene and her children were on their way home to Muiberry Grove, a few miles from Savannah. She was very kind to Mr. Whitney, and he was with her family a great deal on this trip.

When he reached Savannah he found there had been a misunderstanding and that another teacher had been employed, and he was without a position and needed money. Mrs. Greene offered him a home in her family until he could secure satisfactory work. Mulberry Grove, a large and magnificent residence, had been the home of the governor of Georgia. Here the young man spent much of his time wandering over the plantation, talking with the slaves, and doing such things around the farm as came to his attention.

One day Mrs. Greene said that her embroidery 
frame was clumsy and very difficult to manage. Whitney left the room and in a few hours produced one almost perfect in workmanship. She was very much surprised to learn that he had made it, and for the first time recognized his mechanical genius.

The Problem was presented. General Greene had been such a favorite with the soldiers of the South that old army officers and soldiers on their way to and from Savannah frequently stopped to pay his widow a visit. It was in the spring of I793, while Whitney was at Mrs. Greene's, that a party of old army officers and planters from the neighborhood was visiting there. Among them were some old comrades of General Greene,-Majors Brewer, Forsythe, and Pendleton, who lived near Augusta, Georgia. In the course of their visit they discussed the difficulties of agriculture in the upper country, and mentioned the fact that much upland cotton could be profitably raised if they could find some way other than by hand to separate the seed from the lint.

This is what everybody in the South thought, for Arkwright's invention had made a great demand on the whole world for cotton. The people of America knew that the South could supply all the cotton necessary; but of what use was it? It was so difficult to separate the seed that it was cheaper to raise flax and wool. No one knew a way out of the difficulty, although many people were studying the question. Mrs. Greene believed that Eli Whitney could solve the problem, for she had seen him 
make so many things of value. She told her guests all about the young man. While the visitors were

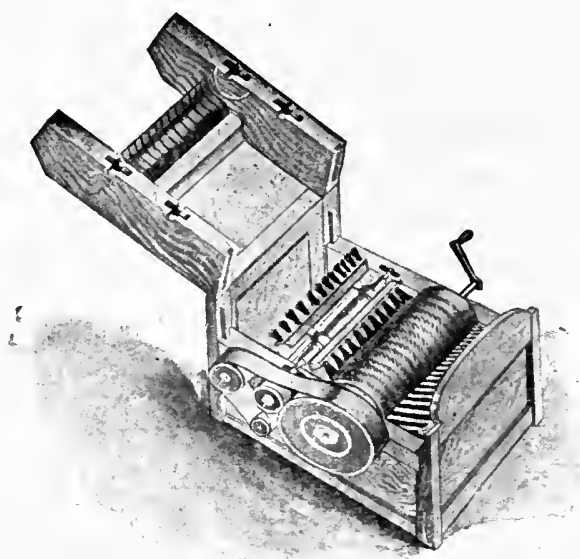

After Whitney's original model in the U. S. Patent Offlce The first successful cotton gin.

discussing the question young Whitney was in his room, reading. Mrs. Greene sent for him and introduced him. He listened to what the gentlemen had to say, and promised to see what he could do. After he left the room Mrs. Greene said to one of the gentlemen present:

"I have accomplished my aim. Mr. Whitney is a very deserving young man, and to bring him into notice was my object. The interest which our friends now feel for him will, I hope, lead to his getting some employment that will enable him to prosecute the study of law."

How the Gin was made. Eli Whitney had already learned a great deal about cotton, but he 
did not know how difficult it was to separate the seed from the lint. He visited the slaves and saw them at work. Men, women, and children sat in circles around the basket and picked the seed ont at night by the light of tallow candles. .

He took home with him a small basketful of cotton and began experimenting. $\mathrm{He}$ made the necessary tools to work with. The overseer of Mrs. Greene's plantation agreed to furnish the money, and Whitney went to work in earnest. Mrs. Greene and her overseer had high hopes of success, and a shop was fitted up in the basement, where the inventor worked behind closed doors.

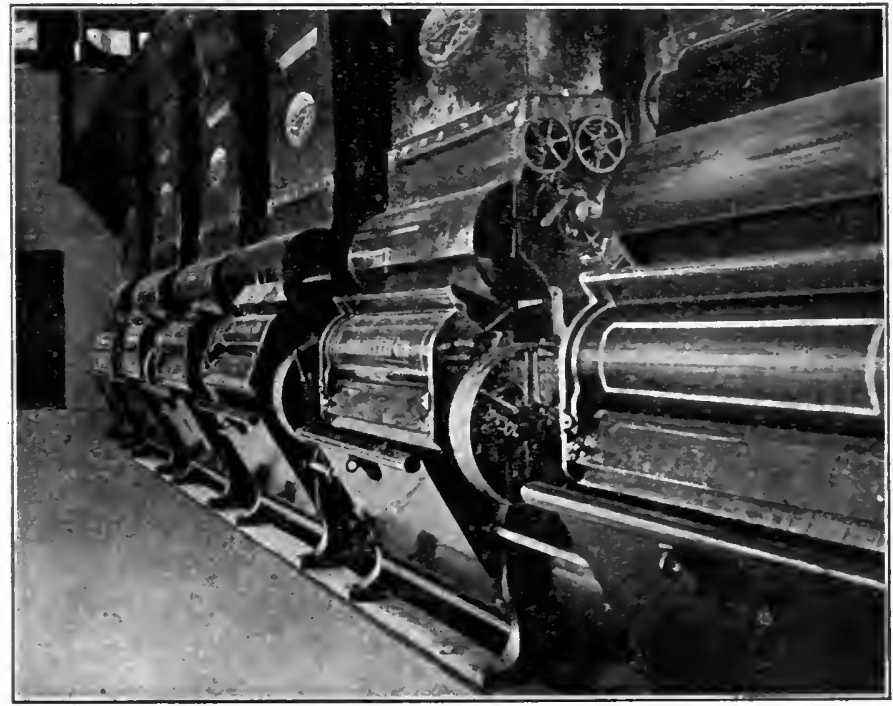

Courtesy of W. A. Simpkins

Interior of a modern ginnery. Note the row of great gins and compare with the original Whitney gin on opposite page. 
After studying his plans carefully he saw that they would work. News of what he was doing spread all over the surrounding county, and neighbors came there in great numbers to see him work the wonderful machine, for it was easy to see that it meant great wealth to them if he succeeded. But they were not permitted to see it, as he did not want any interferences until the machine was completed and patented.

His idea was to take a cylinder and mount it on a strong frame so that it could be turned by hand. On the cylinder were to be rows of nails or wires, called teeth. As the cylinder turned, these teeth were to pass through narrow openings in a curved plate which he first made of wire. When the cylinder turned, its short teeth would catch the cotton and drag it through the grating, tearing the lint from the seed and dropping it on the other side, soft and clean.

It was a success. Mrs. Greene and her overseer were enthusiastic. They knew his fortune was made, and that he had invented a great machine for the use of the planters of the South.

How the Gin was received. Such was the Whitney gin invented in 1793 and patented on March I4, I794. The patent was signed by George Washington, President, Edmund Randolph, Secretary of State, and William Bradford, Attorney General. Every planter who owned an acre of land, and whose plantation was ill-fitted to raising rice or indigo, understood something of the value of this 
patent; and the account that men gave of the strange jumble of wheels and wires, and the wonderful results obtained as the wire teeth pulled the lint from the seed, made all classes eager to behold it.

It is reported that Whitney was badly treated in the South; and these reports have found their way into other books dealing with his great inventions. This seems to rest on the rumor, frequently told, that Whitney's first model was stolen and his patent was appropriated by others, causing much subsequent litigation. The first Whitney gin used wires or spikes in the cylinder. Two years later there was a gin in use in Georgia that used the saw instead of spikes or wires. This saw gin was patented by Hodgen Holmes, of Augusta, Georgia, May I2, 1796, three years later than the Whitney gin, and his patent was signed by George Washington as President, Timothy Pickering, Secretary of State, and Charles Lee, Attorney General. The chief difference was that the Whitney gin used spikes or wires for pulling the lint from the seed. while the Holmes patent used a circular piece of metal with saws cut therein.

When this gin began to be used in Georgia Whitney and his partner brought suit against the company that was selling the gin, and a great litigation was the result. There were tried in Georgia twenty-seven suits for infringement. Whitney claimed that the saw gin was his invention, and that all similar patents or gins were taken 
from his gin. There was evidence introduced to prove that the idea was Whitney's; and there was evidence produced to show that the saws cut in circular pieces of metal were not invented by Whit. ney but by Holmes and were even in use in Georgia within two years after the first Whitney gin. The court finally decided in Whitney's favor. and the sale of the other patent was prohibited. In all these and other litigations that Whitney was engaged in to protect his gin, no mention was made by him that his original models were stolen. This seens to be a myth that sprang up after Whitney's death.

He visited the legislatures of many cotton states and urged them to buy the patent rights for use in their respective states. South Carolina purchased the right for that state, paying fifty thousand dollars. The terms of the contract were such that there was a delay in Whitney's complying with them, but the money was finally paid in full. In I 804 North Carolina bought the right for that state, agreeing to pay two shillings and six pence on each sav used in a gin within the state for four years. The amount paid to the inventor was about thirty thousand dollars.

The Georgia legislature refused to consider any proposition from Whitney, claiming that the saw gin was invented by Holnes, and that as an evidence of the fact there existed the original patent filed in Washington, D. C. But Whitney received from the state of Tennessee about ten thousand 
dollars, making in all about ninety thousand dollars for his invention.

While the world may never know who conceived the idea of the circular gin saw, the original idea was Eli Whitney's, and in 1807 the United States Supreme Court decided the most important case in his favor; and the world to-day acknowledges that he made one of the greatest contributions to the South.

Its Effect on the South. Judge Johnson, a native of South Carolina and at that time one of the judges of the United States Supreme Court that decided the cases in his favor, said of its benefits to the whole country:

"The whole interior of the Southern States was languishing, and its inhabitants emigrating for want of some object to engage their attention and employ their industry, when the invention of this machine at once opened views to them which set the whole country in active motion. From childhood to old age it has presented to us a lucrative employment. Individuals who were depressed with poverty and sunk in idleness, have suddenly arisen to wealth and respectability. Our debts have been paid off, our capital has increased, and our lands have trebled themselves in value. We cannot express the weight of the obligation which the country owes to this invention."

Yet Another Invention was needed. With the appearance of a spinning frame, and the coming of the power loom, cloth could be made entirely of 
cctton; and another valuable feature was that large quantities could be made in a short time.

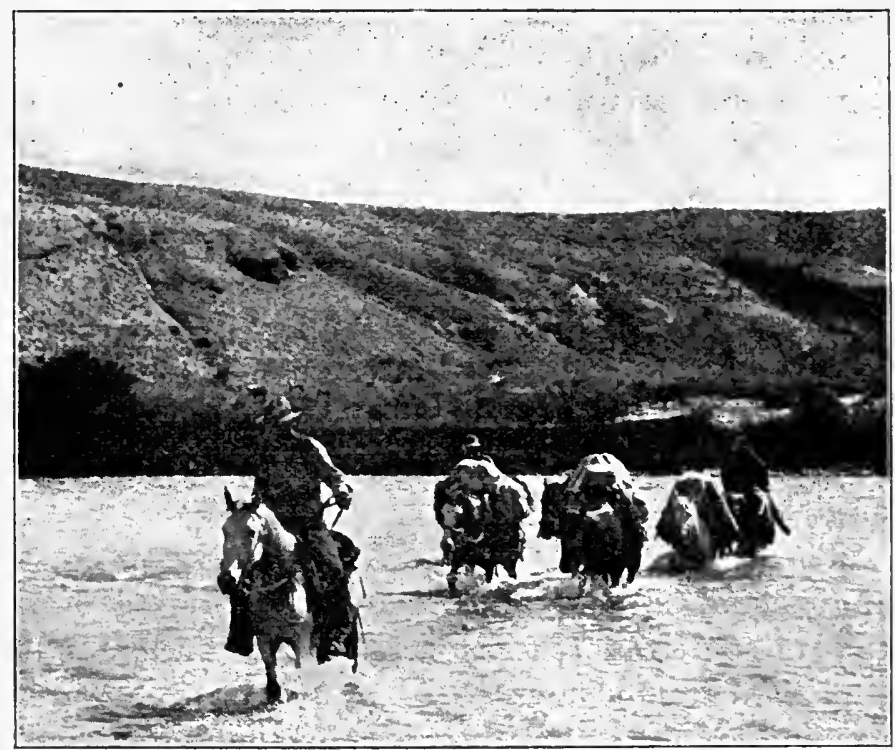

Copyright by the Det rolt Publishing $\mathrm{Co}$.

Pack horscs fording a stream.

These machines were capable of doing the work of hundreds and thousands of men, women, and children. With the perfection of the cotton gin it was now profitable to raise more than a few patches of cotton. Hundreds and thousands of acres were cultivated, and the product brought wealth to the planters. This was especially true of the planters who lived near the rivers. There were no railroads in those days, and travel in the back countries was slow and difficult. Families living 
fifty, a hundred, or even two hundred miles from navigable streams were compelled to travel on horseback almost entirely, for there were almost no roads, and what existed were very rough and for many months in the year almost impassable.

Pack horses or covered wagons were employed in carrying the necessities of life, such as salt and other things that could not be made on the farm. Travel was slow and merchandise was hard to get; therefore, for many years families still employed the spinning wheel and the hand loom for making their own clothes.

It required one other invention to make all humanity debtors to the cotton field of the South. It came before either of the inventions mentioned above, yet it was the slowest in developing. This was the steam engine, which has been the most far-reaching of all the inventions in its influence on the world.

The Story of James Watt. When George Washington was four years old there was born at Greenock, Scotland, a little child, weak and always sickly, whose work has affected the lives of more living people than any other man in ancient or modern times. This man was James Watt, the inventor of the steam engine.

The father of James Watt was a merchant, and a magistrate in his town. The family then was of some local note. James, always very delicate, even as long as he lived, was unable to attend school regularly, though he did not allow his poor 
health to hinder his education. Although unable to attend school he pursued his studies at home, where, without much assistance, he succeeded at an early age in making himself proficient in many branches of knowledge. His special study was mathematics and mechanical science.

When he was eighteen years of age he was sent to London to become a maker of mathematical instruments. His health, however, was such that he was compelled in a short time to return home. But he learned enough in the meantime to give him some prominence, and when he was twenty-one years old he went to Glasgow, where he was appointed maker of mathematical instruments in one of the colleges. There he studied very hard, and was associated with some very celebrated men who, seeing his industry and desire for knowledge, gave him every assistance possible.

He worked in this institution until he was thirty years old. His salary was small, too small to support a family, and he desired to marry. He decided therefore to leave the university and enter upon the profession of a general engineer. Accordingly he soon acquired a high reputation in surveying and planning canals, harbors, bridges, and other public works. While his body was very feeble, his mind was intensely active, and he was very successful.

How the Steam Engine was made. Long before James Watt was born, numbers of people had studied the force of steam and observed its 
peculiarities. A few had written about it and attempted to make an engine that could use it.

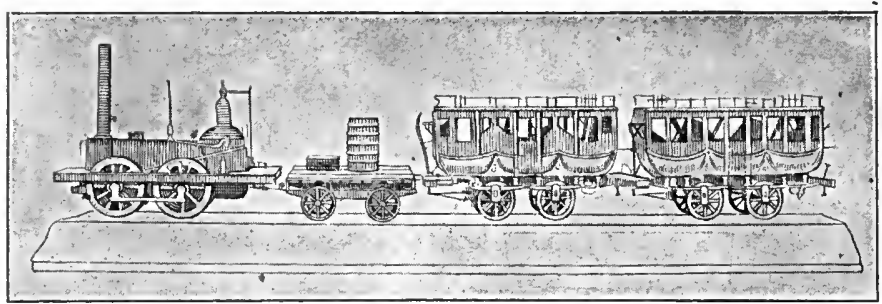

From Mace's School History of the United States

The first train operated over the Pennsylvania Railroad, 1835.

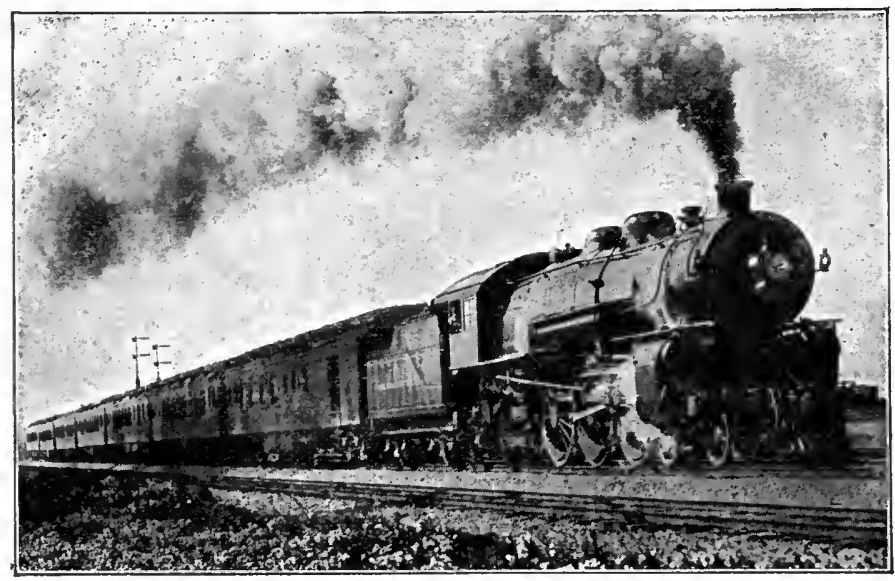

Copyright, 1909, by Wm. T. Skinner Courtesy of $\mathbf{N}$. $\mathbf{Y}$. Cent. Lines

A limited train of the twentieth century.

Steam issuing from the mouth of a kettle was no new thing. Even before the Christian era attempts were made to use this power; but it was thought that it would be necessary to make a volume so large and powerful that its force, leaving 
the mouth of a vessel, would in striking a van or wheel move it somewhat as water moves the wheel of a mill, by pouring on it.

It was several hundred years after this before it was discovered that steam is most powerful when compressed in a tight vessel or cylinder. We all know that if water continues to boil in an air-tight

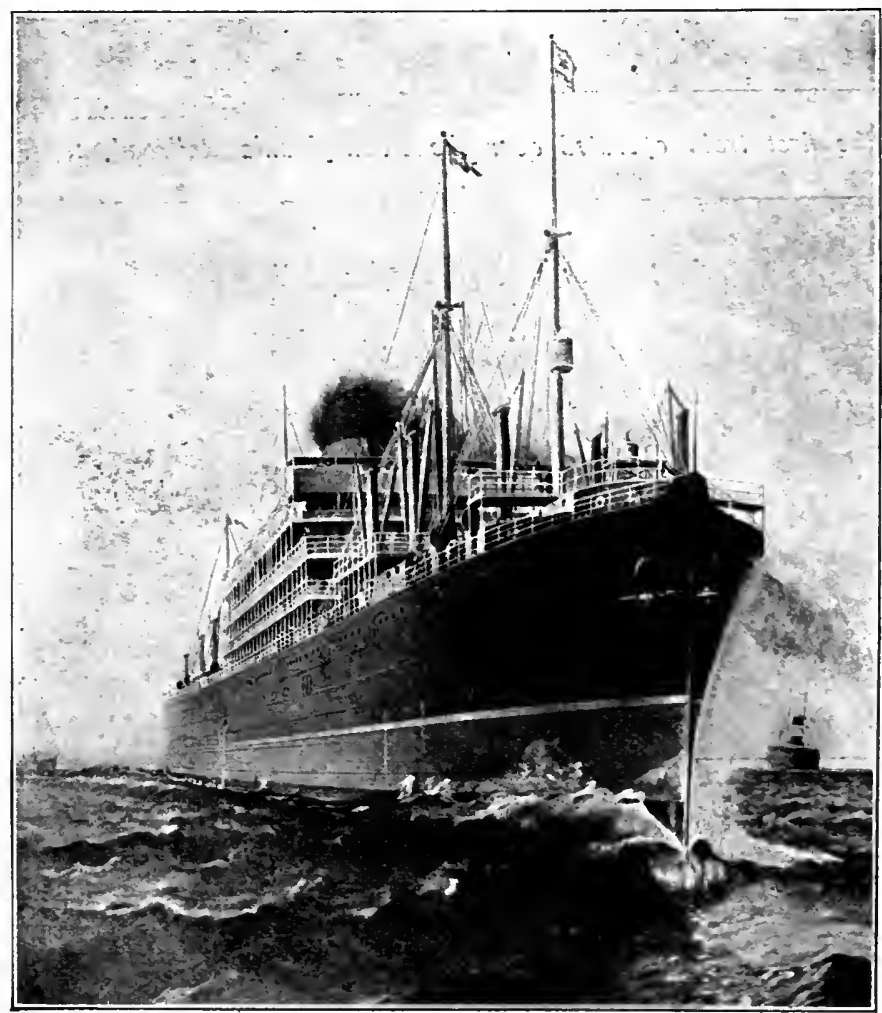

From Commercial Geography by E. V. Robinson A great modern commerce carrier, the Minnesota. 
vessel it will burst the vessel. The force of the steam compressed thus is powerful.

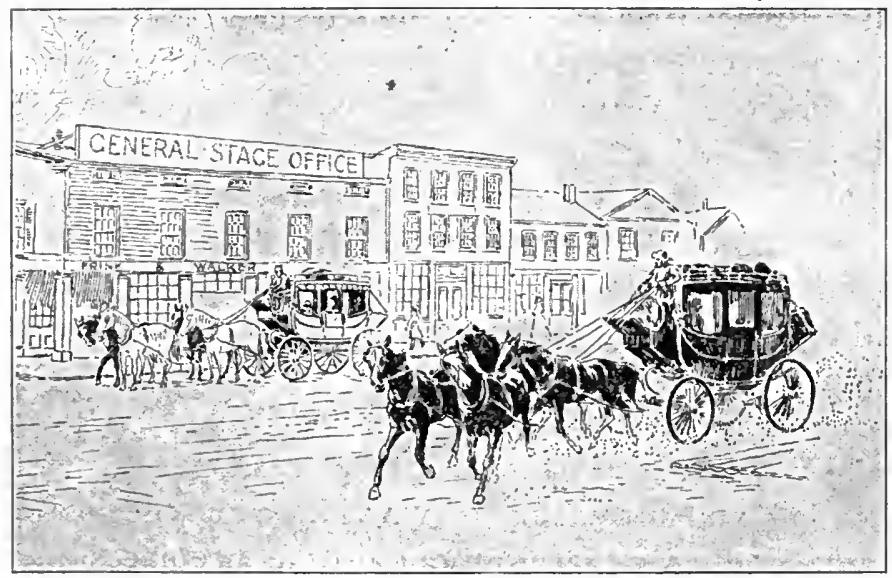

From The Story of Chicago by Jennie Hall In the days when we traveled by stagecoach.

But how could steam be used in an air-tight vessel or cylinder? A few men came very near answering this question, but it was James Watt who succeeded, and in the same year that the batthes of Lexington and Concord were fought he organized a firm for the business of making steam engines.

All schoolboys to-day have seen a steam engine; there are even those who know how to turn the steam on and start the wheels going round. They know that the wheel turns round as the piston moves back and forth, and that it is the steam compressed in the cylinder, first on one side and then on the other, that moves the piston.

Effect of the Steam Engine. When George 
Washington was President this machine was as much a curiosity to him as the flying machine is to us. Since its appearance the old stagecoach drawn by four or six horses, trotting about eight miles an hour, has disappeared and is an ancient relic, having been replaced by the fine locomotive trains with sleeping cars that speed along at the rate of forty miles an hour, carrying hundreds of people and tons of mail. The steam engine has entered the shops of the blacksmith and metal worker and replaced the slow methods of hand workmen. It can engrave a seal, crush a mass of metal like wax, draw without breaking a thread as fine as gossamer, and lift a ship of war like a bubble in the air. It has replaced the old-time fireplaces and the more modern stoves in the larger buildings, for it can make the coldest skyscraper as warm as the tropics. It has replaced the old water wheel in manufacturing. It can embroider muslin, weave carpets, make clothes, forge anchors, cut steel into ribbons, and turn out tons of nails every hour of the day. It has replaced the old masted schooners for commercial purposes. It can drive vessels as large as small islands against the fury of the wind and waves, and transport thousands in comfort where the old vessel could carry one and torment him with a multitude of inconveniences. It has made slave labor profitless, for it carries the cotton from the fields, dumps it into the gin hopper, separates the lint from the seed, rounds it up into bales, carries it to the best markets of the world, 
changes it into yarn and fabrics of a thousand varieties, makes it into clothes, and brings it back to the planter who first planted the seed.

Effect of these Three Inventions on the World. When these three inventions were perfected the world entirely changed its course. Where the

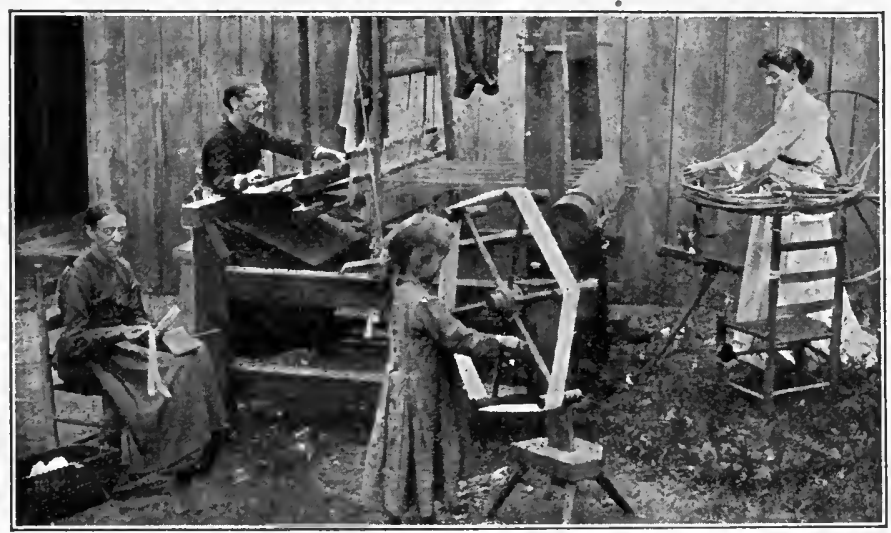

A primitive cotton factory in Alabama. The cotton grown in the home patch is here being carded, spun, reeled, and woven into cloth, later to be made into clothing for the family.

South had raised a few thousand pounds of cotton, it soon produced many millions. The world has almost forgotten that India once wove such fine cloths and that Europe once depended upon this far-away peninsula for so many of her luxuries. Women no longer take their spinning wheels on the courthouse green. or to the house of the parson and spin thread from morn until night, while they listen to sermons on the industry and economy of the home. The spinning wheel is hid away in the attic and the loom has fallen in pieces 
save in a few isolated homes. Great cities have been built in Europe and America on the cotton industry of the South. The pack horse and the slow wagon are a part of the history of ancient days, and long trains of cars loaded with hundreds of bales of cotton hurry across the country, and thousands of vessels loaded with many thousands of bales plow across the ocean, carrying the lint of the South to the cities of the world, where a million men, women, and children are dependent upon the crops of the South for their daily bread.

In the time of Columbus Europe asked, "How can we reach the cotton of India?" Since these three inventions have appeared the world asks, "How can we reach the cotton of the South?" 


\section{CHAPTER VII}

The Coming of the Factory to America

How the States tried to secure the Arkwright Machines. We have seen that the spinning jenny, the spinning frame, and the power loom were all invented in England. In order to encourage the development of these machines at home and to keep among their own manufacturers the secret of spinning and weaving cotton, England prohibited the selling or sending of these machines to any country, and especially to America, where cotton was cultivated so successfully.

In America great efforts were made to secure these new machines; but the British government was guarding them with the utmost care lest she lose her supremacy in manufacturing cotton. The South had the cotton gin, and the cultivation of cotton was being doubled and quadrupled. Since it was so easy now to separate the seed from the lint, cotton cultivation became a very profitable industry. A large part of this cotton began to go to the English manufacturers; for the home folks had to use the old hand loom, and the better goods could not be woven in the old way. England was now becoming famous in the manufacture of cotton goods, and the quantity of cotton goods 
brought from India was growing less and less. Manufacturing societies of America sent men to study the mills of England and to bring back workmen skilled in handling the Arkwright machines. Repeated efforts were made to reproduce in the United States the machinery used with so much success in England. In every attempt the Americans at first failed, and, a thing which aggravated the situation, English manufacturers were exhibiting each year finer and more beautiful fabrics in the markets of America. Many states offered bounties to mechanics to induce them to reproduce. the machines in America. Manufacturing societies both North and South offered great inducements to any who would introduce the machines; but all the while England was becoming more and more famous, and America was spending larger and larger sums of money trying to secure the machines.

The Efforts of Tench Coxe. Tench Coxe, a Philadelphia manufacturer, determined, immediately after the Revolutionary War, to secure a set of the Arkwright machines. At the same time he encouraged the Southern planters to promote in every way the cultivation of cotton. An agent was procured in England to reproduce a set of the Arkwright models and smuggle them out of the country. A large reward was offered, and a full set of very small models in brass was made. They were more like a child's playthings, but they were complete in every respect. But English 
spies were always on guard, and just as the models were on the eve of being shipped to America they were seized. After this failure Tench Coxe and others increased their efforts and published widely their offers of rewards to the person who could reproduce in America the Arkwright machines used so successfully in England; for the cotton of the South was just beginning to be shipped to England on a large scale and brought back to the United States in the shape of calico, dimities, and other fabrics. Many imitations of the Arkwright machines were produced, some of which worked with a fair degree of success; but all that time the machines of England were being improved. English manufacturers believed that their cotton manufacturing business would be ruined if America ever learned to use the Arkwright machines, so they were guarded with the greatest care.

Samuel Slater. A young man by the name of Samuel Slater, of Derbyshire, England, who was early apprenticed to a partner of Richard Arkwright, and who had learned the cotton-mill business thoroughly, so thoroughly that he himself had worked some improvements into the machines, turned his attention to the United States. He learned of the rewards offered by that country for the encouragement of manufacturing. Picking up a newspaper one morning he read the account of a liberal bounty granted by the legislature of Pennsylvania to a person who had succeeded but poorly in constructing a carding machine. He read 
further of large rewards authorized by the same legislature for the promotion of manufactures. This decided him. He would come to America.

Slater perfected his plans secretly. He knew that a mechanic, especially one that knew the Arkwright machines so thoroughly, incurred many

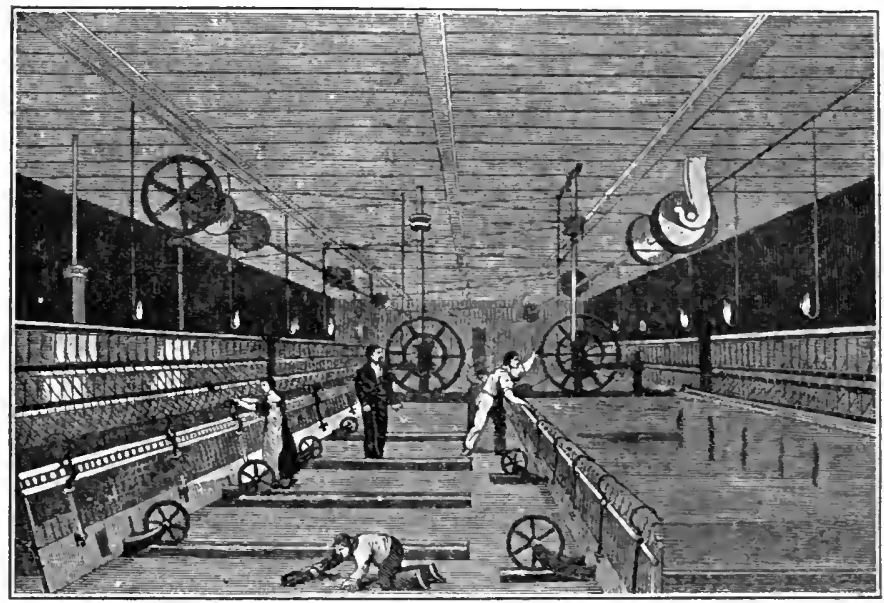

After an engraving in White's Memoir of Samuel Slater

Interior of the first cotton mill in the United States. Mule spinning. Compare with the viers on the opposite page.

dangers in attempting to leave England. Therefore he took no drawings, papers, or anything that could betray him. He embarked in September, I789, at the age of twenty-one years, and after a tedious passage of sixty-two days he landed in New York without funds or friends, but being such a skilled workman he soon found employment.

In discussing the cotton manufacturing business with workmen of New York he learned that recent 
attempts had been made to erect in Providence, Rhode Island, a factory for spinning cotton. He addressed a letter to Moses Brown, the proprietor, and very soon he received an answer requesting him to come at once. On his way he stopped at Pawtucket, Rhode Island, where Moses Brown

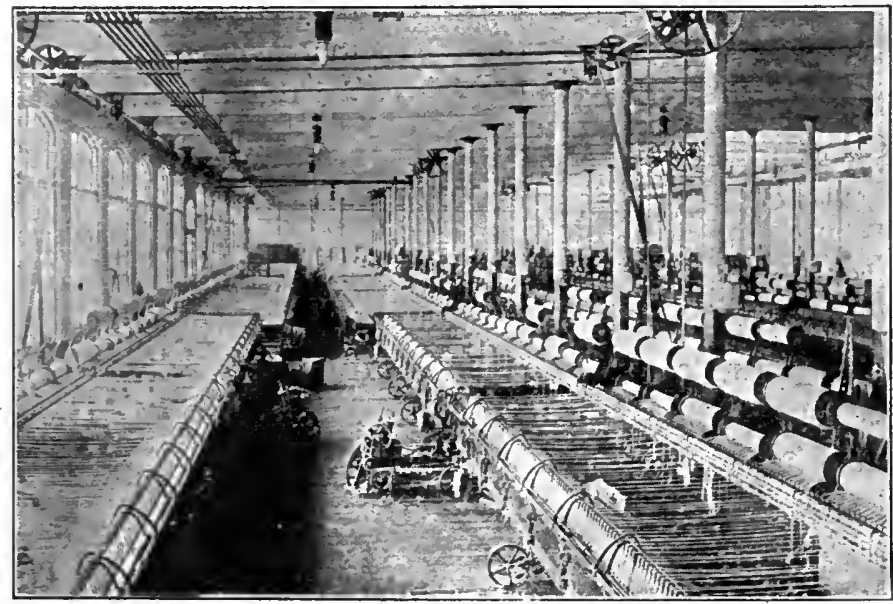

Courtesy of Marshall Field \& Company

Interior view of a great modern mill, showing mule spinning and jack spools.

wished to show him the machinery of the mill which had been erected there. At sight of the different machines Samuel Slater was discouraged. He said to the proprietor, "These will not do; they are good for nothing in their present condition, nor can they be made to answer."

They were not the Arkwright machines. Other mills in New England were making efforts to spin the finer thread with this old machinery. Finally 
Samuel Slater proposed to reproduce the Arkwright machines, and he added, "Under my proposal, if I do not make as good yarn as they do in England I will have nothing for my services, but will throw the whole of what I have attempted over the bridge." And the firm of Almy, Brown \& Slater was formed at Pawtucket for. spinning cotton.

Although the young man had full confidence in his own ability to remember all the parts of the machine, he had the greatest difficulty in finding workmen who could make them after his drawings. One part after another, however, was finally made. Yet his anxiety increased. He was boarding at the home of Oziel Wilkinson, whose family were strong Quakers. One day they saw the young man leaning his head over the fireplace and uttering deep sighs.

"Art thou sick, Samuel?" asked Mrs. Wilkinson. "No," said he, "but if I am frustrated in my carding machine they will think me an impostor," and he knew that he could not import one from England.

Samuel Slater's Success. But on December 2I, I790, the machines were in readiness, the water was turned on, and Samuel Slater was famous. Three years later, in the same year that the cotton gin was invented, a small factory was built in Pawtucket. It is known to-day as the "Old Mill."

The firm Almy, Brown \& Slater was only carding, roving, and spinning cotton. But in a short 
time American manufacturers were so enterprising and labor was sufficiently skillful to enable the manufacture of cotton cloth to be established on a firm basis.

Samuel Slater was a philanthropist.' He not only introduced improved methods of spinning cotton but he was the first to establish the Sunday School in America. It was organized in his own house for the purpose of teaching the children of his employees how to read and write.

He became very wealthy, for his business interests increased at a tremendous rate. After his death on April 21, 1835, the Rhode Island Agricultural Society said of him:

"What shall the people of New England do for him who first brought us the knowledge of manufacturing cloth by machinery moved by water! In England, he would in life be ornamented with a peerage; in death, lamented by a monument in Westminster Abbey. The name of Slater will be remembered as one of our greatest public benefactors. Let not the rich in his adopted country envy the products of his labor, his extensive opulence, his fair and elevated character. Let the poor rise up and call him blessed; for he has introduced a species of industry into our country which furnished them with labor, food, clothing, and habitaticn."

The Complete Factory. Samuel Slater's success at Pawtucket demonstrated the possibilities of this new industry. Men trained in his mill went out 
to the other states and set up factories for spinning cotton; but as yet they were unable to weave the finer goods such as were made in England. Factories were in operation in South Carolina, Georgia, and North Carolina as well as in Massachusetts, Connecticut, New York, New Jersey, Pennsylvania, and Maryland. But the factories were not complete.

In I8I4 Francis C. Lowell returned from Europe, where he had gone to study the cotton manufacturing business. The United States was again at war with England, and the inhabitants of the states were unable to secure even the manufactured goods in England, though they were more than ever determined to produce the finer goods in their own country. On his return Lowell put into use the knowledge he had gained in Europe. He planned and constructed the first cotton mill in which all the processes of carding, spinning, weaving, and printing were carried on under the same roof. The venture was a brilliant success. Women-could operate the looms and children the spinning frames. The complete factory had finally come to America.

Even before this complete mill was constructed at Waltham, Massachusetts, Tench Coxe, who had been encouraging the manufacturing industry since the Revolutionary War, and who is justly called the father of American manufacturing, said of the new industry:

"These wonderful machines, working as if they 
were animated beings, endowed with all the talents of their inventors, laboring with organs that never tire, and subject to no expense of food or bed or raiment or dwelling, may be justly considered as equivalent to an immense body of manufacturing recruits, enlisted in the service of the country.",

The year after Lowell completed his mill the amount of cotton raised in the South reached 209,205 bales. What an increase since the day Samuel Slater landed! But I63,894 bales were shipped to Europe. France, Italy, and Spain were manufacturing cotton also. The South was almost driving the cotton of India, China, Egypt, and Brazil out of the market; and in the future these ancient cotton markets were destined to grow less and less in importance, and the trade routes to the South were to form a large part of the world's commerce. But from the amount of cotton shipped to Europe it is easy to see that America was far behind in manufacturing. The United States was really only beginning to understand the art.

The Factory in the South. It was natural that South Carolina and Georgia should make early attempts to manufacture the cotton near the plantations on which it was produced. Mrs. Ramage, the widow of a South Carolina planter, was possibly the first to undertake the establishment of a factory in that section. Her mill was erected on James Island, near Charleston, in I787. It was small in size and was operated by horse power. 
Some years later another factory was built. Three years later a factory for spinning cotton which was run by-water power was built at Statesboro, South Carolina. The next year carding and spinning machines were operated in East Tennessee. Soon these carding and spinning factories węre established in Georgia. These factories did not at first use the improved Arkwright machines. But after Samuel Slater erected the first factory with inproved machinery, we find the Southern mills profiting by the improvements also.

In I8I3, the year before the Lowell mill was erected, North Carolina built her first factory for spinning cotton. It was located on a small stream in Lincoln County in the Piedmont section of the state. The machinery was purchased in Providence, Rhode Island, was shipped by water to Philadelphia, and from there was hauled by wagon to Lincoln County, a distance of over five hundred miles. This mill succeeded so well that it was enlarged three years later and others were built.

Virginia was probably leading all the states in homespun cotton manufactures, and Virginia. South Carolina, and Georgia had more homespun cotton manufactures thąn all the other thirteen states combined.

However, this activity in manufacturing cotton goods in the South was of short duration. Lack - of transportation, lack of skilled labor, and the great demand for cotton turned the attention of the Southern planters away from manufacturing. 
They loved the free, open, outdoor life of the large plantations and objected to the factory village life. In the cotton belts the laborers were needed in the fields, and in the Piedmont countries there were the difficulties of transportation.

The Demand for Cotton increases. England, Scotland, Ireland, France, Germany, and other European countries were soon calling for cotton. Every state in the United States was calling for cotton, and the Southern p!antations were growing in importance. Why hinder this industry by trying to build factories?

A new life was felt in the South. Attempts were made to improve cotton culture ; agricultural societies were formed, and everywhere there was activity to promote the industry. A new kind of cotton was introduced into South Carolina which has since l.ecome known as sea-island cotton, and is the most valuable cotton produced, since its fiber is very long and exceedingly fine.

In the South as well as in the North home manufacturing had been encouraged until the close of the second war with England, and in I8Io, according to Tench Coxe, the value of the textile products of North Carolina was greater than that of Massachusetts. Both sections of the country had been developing hand skill, and neither section had the advantage over the other. But with the coming of the complete factory a new division of labor began which was to change the economic, social, and political ideals of both North and South. 
Effect of the War of I8I2. At the opening of the nineteenth century all Europe was at war. Napoleon Bonaparte was the central figure of the world, and England was engaged in one of the bloodiest wars in history to break the power of Napoleon. The United States at the same time was making every effort possible to build up a great commerce and at the same time avoid taking any part in the European war. In I805 the English fleet under Admiral Nelson destroyed the French fleet at Trafalgar, and England as a result was mistress of the sea. No flags appeared on the high seas except those of England and the United States. England needed sailors, and her men-of-ivar were accustomed to cruise along the American coast, and, overhauling our trading vessels, inspect the crew and take away the sailors who could not prove American birth. This was an insult to American commerce.

In 1806 England went a step farther, and announced that no neutral ship might trade with France or her allies until she had first touched at a British port and paid reëxportation duties. This was the second insult to the American commerce, since it meant that American cotton could not be shipped to France or to any of her allies, and her vessels could not in turn bring back the goods needed in America. The cotton of the South formed a large part of the trade with Europe, and American vessels were readily seized and cargoes taken by British vessels. 
Thomas Jefferson was at this time President of the United States, and he desired above all to avoid war with any of the European countries. Owing largely to his influence Congress in 1807 passed the Embargo Act, which prohibited American vessels already in harbor from sailing for a foreign cruise. This state of affairs, of course, could not last many years, and soon the United States was again engaged in a war with England.

In 1808 there were fifteen cotton factories in the country with eight thousand spindles. In I 8 I I the number of spindles had increased to eighty thousand, and by I8I5, the year the war closed, there were five hundred thousand spindles in operation. In I 800 the home manufacturers consumed five hundred bales of cotton, but in I8I5, ninety thousand bales. This increase was considerably larger in New England than in other sections of the country. Those engaged in commerce at the time the Embargo Act was passed now put their capital in manufacturing, and at the close of the war the capital invested in the cotton and woolen industries in the United States was about fifty million dollars. The whole country turned to manufacturing, for war compelled the people to rely upon their own skill and industry, and to learn to make many of the goods that they had previously been buying in Europe.

Why the Factory first found a Home in New England. A study of the physical features of New England and of the South will disclose the fact that 
the leading occupations followed by the people of both sections were naturally different. In New

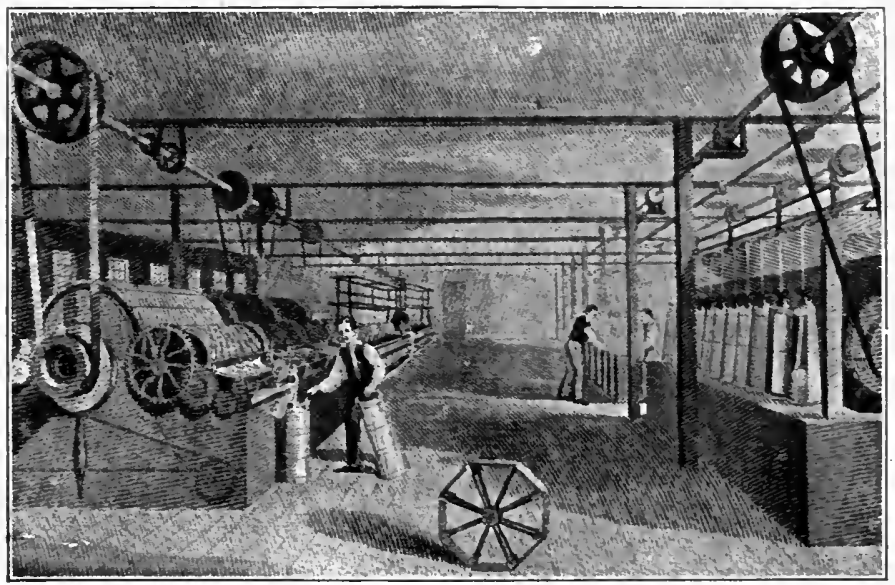

After an engraving in White's Memolr of Samuel Slater In a cotton mill, I79o. Carding, drawing, roving, and spinning. England the mountains are near the seacoast and the land is hilly, rocky, and little suited to agriculture. The rivers are short and swift, and the water rolls rapidly to the sea. The inhabitants have a!ways had a tendency to live close together in towns and cities, and their occupations of necessity were influenced by the climate and physical features of the land.

In the South the conditions are vastly different. The mountains are far removed from the coast. The rivers are long, and flow lazily througl wide areas of level land of rich alluvial soil. The first inhabitants that landed from their boats on any of the Southern river banks could look away across the 


\section{The Coming of the Factory to America 123}

country for miles, and see broad areas of fertile land through which roamed the deer, the buffalo, and wild game of all kinds in abundance. It was easy to live there. Indian corn grew in the river valleys with little cultivation. After this section of the country was settled a few patches of cotton and flax supplied the light clothing. Sheep, hogs, and cattle ran at large and fed on the products of the forests, where grasses and berries and nuts relieved the early settlers of all responsibilities. With his rifle the colonist could supply food in abundance

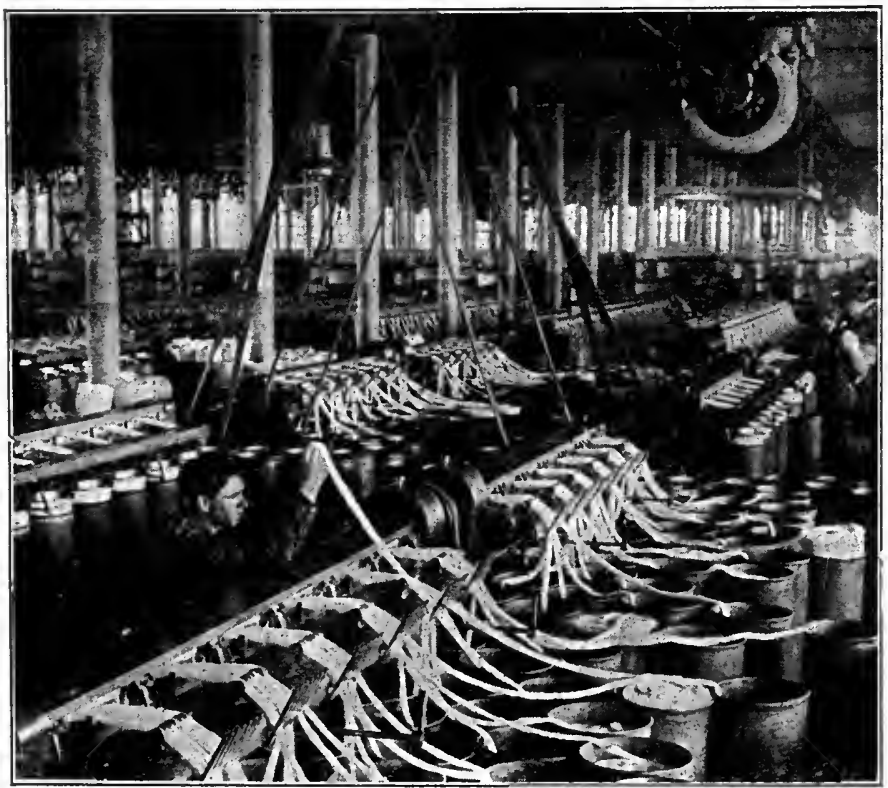

Copyright by Underwood \& Underwood, N. Y.

A drawing room in a great modern South Carolina cotton mill. As the cotton sliver passes between the rollers of the drawing frames the thread becomes finer and finer. 
for his table and skins for his heavier clothing. He was not aependent upon his neighbors for anything. He desired wide areas for hunting privileges and deep forests for his sheep, cattle, and hogs. Later, when it was discovered that tobacco was a valuable article and that Europe would pay high prices for it, the plantation system of the South was begun.

At first there was a tendency in the South to grant only about a hundred acres to a settler, but later, in order to encourage immigration, there was scarcely a limit to the size. From a hundred acres it was increased to a thousand, then to ten thousand, and in a few instances to a hundred thousand acres.

In New England the land was granted to groups of individuals or to congregations, and the system provided for settlements by townships. After the settlement the land was parceled out in small tracts to individual families, and the nature of the settlements produced a community or village life. If new land was needed, a new township was laid off and settled in a similar manner. The result was a colony of townships where the individual had his small tract of land carefully surveyed before the settlement. In the South the granting of large plantations distributed the settlers over wide areas. In many instances the owner of the land lived in Europe or in Virginia or on a distant plantation. In New England strict provisions were always made for the improvement and settlement of the 
lands purchased. But in the South the method of holding land produced a colony of isolated homes built on plantations of many hundred acres supported by servile labor. The village or community life was impossible. A merchant class was hardly needed, for vessels came up the rivers, brought the merchandise to the planter's own home, and took the products of the farm away to foreign countries; hence few towns were built, and these were slow in developing. If we look at the map of the South to-day we still see very few large cities, and the towns are much farther apart than in New England. When the factory came to America, therefore, it found its natural home in New England, and the people of the South, with their large plantations, entered the new Economic Era not as cotton manufacturers but as cotton producers.

How the Cotton Industry affected Labor. The first useful laborers employed in America were white servants known as "indented servants." They were either sent over for some crime they had committed, or were kidnaped on the streets of the cities of Great Britain, or they were taken up for debts, shipped to America, and sold to the colonists of the South and the North. Their term of service with the planters was not for life, but merely for a term of years.

When negroes were first brought to Jamestown these white servants were in service on the farms and in the homes. The negroes were very ignorant and unable to speak the English language; 
therefore they were of little value until they could be taught to speak the language of the people and to contorm to the demands of their masters. However, as they became better educated they were more valuable. Traders found it more profitable to obtain and sell negroes than white servants. The former became much more useful in the cultivation of tobacco in Virginia and North Carolina and in the cultivation of rice and indigo in South Carolina. As the demand for these products increased, the demand for negroes increased, and the size of the cultivated farm increased. Tobacco, rice, indigo, tar, pitch, and turpentine were making the planters of the South rich. Since no skill was required in these occupations, slave labor soon displaced all other forms of service; and the negro increased in value.

In New England different conditions gave rise to a different labor system. There the wealth of the settlers did not come from the cultivation of the soil. They converted the timber of the forests into staves, masts, and ship-building material. They sent out fishing vessels along the coast and brought back the products of the sea. They organized hunting parties and took the fur from the animals and shipped it to England. They imported cotton and wool and manufactured them into clothing. All these industries required a different kind of labor, and the negro was not skillful enough to be profitable.

In the South, however, after the cotton gin had 
made it profitable for the planters to produce large quantities of cotton, and after the factory had created such a demand for it, the Southern planter needed field laborers. As he increased the size of his plantations he needed to increase the number of his servants, and the negro became a necessary factor in the production of cotton.

In New England people lived in towns and increased their skilled labor; in the South people lived on large plantations and increased their slave labor. In New England the factory called the skilled workman from the country and increased his skill in every way possible; in the South more cotton was cultivated and more slaves were needed.

\section{How the Cotton Industry affected the Social} Life. With the coming of the factory, women ceased to assemble on the public squares and spin and weave while they listened to lengthy discourses on domestic economy, for the old spinning wheel and hand loom began to disappear. The factory, with its rapid machinery, took the occupation of spinning and weaving out of the homes, and girls and boys, old men and old women, were drawn from the simple country life to crowded factory towns, and they learned to manipulate the delicate machines, thousands of them working under the same roof. Previous to this time each home, botlr North and South, had been a separate, independent unit, making its own necessary food and clothing, and with the surplus earnings purchasing a few of the luxuries that came from distant 
lands. With the coming of the factory every home was affected; labor was divided, and each section of the country became dependent upon the other sections for even the necessities of life.

The factory found a home in New England and the Middle Atlantic States. If the inhabitants of this section engaged in manufacturing, another section must supply the raw material, and this the South could more easily do. Therefore the South became a great agricultural section. But manufacturing required skilled labor, which meant intelligent labor; the raw material could be produced in sufficient quantities by unskilled slave labor. So the wealth of one section came to be based on skilled labor, and of the other on unskilled labor; and in the long run of years it is easy to see which section would triumph, for no people can remain powerful long whose wealth comes from the labors of unskilled workmen when adjoining states rest their wealth on the labors of skilled workmen.

If the wealth of one section rests on the activities of intelligent labor, an educational system for all laborers must be established; but if it rests on the activities of ignorant laborers, only an educational system that will train the rulers or managers is necessary, and we have two different educational ideals. This also explains why the public school developed earlier in the non-slave-holding states than in the slave states.

How the Cotton Industry affected Politics. By the close of the War of I8I 2 the factory had come 
to stay. England, eager to kill the manufacturing spirit which had been fostered early, sent shiploads of cotton goods to America and offered them on the most liberal terms. The goods were taken on credit and disposed of at auction. In 1816 the importations from England amounted to one hundred fifty-five million dollars. Woolen manufacturing was ruined; cotton manufacturing was seriously threatened; the bagging industry of Kentucky was destroyed; and it appeared that America did not have the skill and facility for competing with England. It was in this year that the Secretary of the Treasury advocated the protection of domestic industries against similar European industries. A bill looking to the protection of American industries was therefore introduced. It was championed by South Carolina, opposed by Massachusetts, and passed by the aid of the Middle Atlantic and Western States. It found support and opposition in nearly every state in the Union. Then was begun our high protective tariff, which was to cause so much discussion in Congress and all but divide the Union.

\section{How the Factory influenced Cotton Cultivation.} The cultivation of tobacco and rice was fast exhausting the land; but when the three great inventions mentioned in a former chapter were given to the world the era of the great plantation system of the South began. In the ten years following the invention of the cotton gin the number of bales of cotton produced in the South increased from about 
ten thousand to one hundred twenty-five thousand. North Carolina, South Carolina, and Georgia were the first states to go to any great extent into cotton cultivation. The price of cotton in 1790 was twenty-six cents a pound; but in I799 :s was selling at forty-four cents a pound. The demand for cotton increased the value of the slave, which went from about three hundred dollars to over eighteen hundred dollars.

The little cotton patches cultivated in the gardens of the colonists when George Washington was a boy were now great plantations of thousands of acres and hundreds of slaves. The plantation was a small kingdom, and the landlord counted his subjects by the hundreds. Not only were the slaves dependent upon him, but the poorer white people of his county looked to him for advice and counsel. He bought his clothes in London, while his slaves spun and wove the cloth for the subjects of the plantation. They made in the workshop all. his wagons and plows, his mills ground the corn and wheat and sawed his own lumber for building purposes, and his negroes tanned the leather and made the shoes. His vessels came up the river and landed at his door the merchandise that had been bought in Europe, and then carried to the markets of the world his cotton and tobacco. The planter was independent. He ruled at home, and shaped the policies of his country.

When the factory came to America a new industrialism began in the North and East. Its power 
was ill judged and its influence was not even approximately estimated. The plantation aristocracy of the South was not changed, but made stronger. The North and the East were made over almost entirely, but the South continued and confirmed its civilization, and this was a reason given why that civilization should not be restricted in any way. 


\section{CHAPTER VIII}

How Cotton sectionalized the South

Wealth is due to overcoming Geographical Limitations. The strength of a people is determined by their ability to overcome geographical limitations or to change their environment. An old worn-out hillside is a poor place to look for food; but the skill of the farmer may overcome certain geographical limitations and make it yield abundantly. England geographically is not the country, on account of her great distance from the cotton fields, to produce the greatest amount of manufactured cotton goods; but the skill of her laborers, through the improvements in machinery and governmental protection, have overcome geographical limitations. Massachusetts geographically is not the state to consume the most raw cotton; but the skill of her laborers, through the improvements in machinery and governmental protection, have overcome all geographical barriers, modified their whole environment, reversed the natural order of things, and to-day levies tribute on every cotton state.

We may lay it down as fundamental that in this modern era no state can become powerful, or retain its power indefinitely, if its wealth is based upon the industry of unskilled labor. Geographically 
North Carolina, South Carolina, Georgia, and Tennessee should hold a monopoly on cotton and its finished products. Geographically the lowlands of these states are most favorable to cotton production and the Piedmont states to cotton manufacturing; but the skill employed in these states, with all their natural advantages, must equal the skill of the rest of the world before cotton will cease to levy tribute on the Southern States of America for the enrichment of the rest of the world. This process has been going on for a hundred years. The South expected wealth to come from slave labor while the rest of the world was employing skilled laborers capable of making and manufacturing the most delicate machinery, and it required no looking into history to see which would lose and which would win, for skill always triumphs over ignorance.

How Economic Changes forced the South into Cotton Production. A comparison of the geography of the two sections shows that the Southern States had certain advantages in their favor; and for the time the South dominated the nation.

By I820, however, a national policy had been outlined. Economic changes, owing to the new inventions mentioned in a former chapter, had created this new nationalism. The wealth of the South was located in the tide-water sections, that is, below the fall line. In the black belts and low countries it was firmly believed that white men could not work in the fields, owing to unhealthy climatic conditions. Now these were the sections 
of the South in which cotton was chiefly produced; and the world was calling for ever larger quantities of cotton and the price was attractive. Therefore new plantations were opened up, new states were formed, and slavery became very profitable.

The South without slavery might have had a different history, but with slavery grown into her industrial life, a social condition developed which involved an aristocracy of land and landlords, a sort of modern feudalism. This development com-

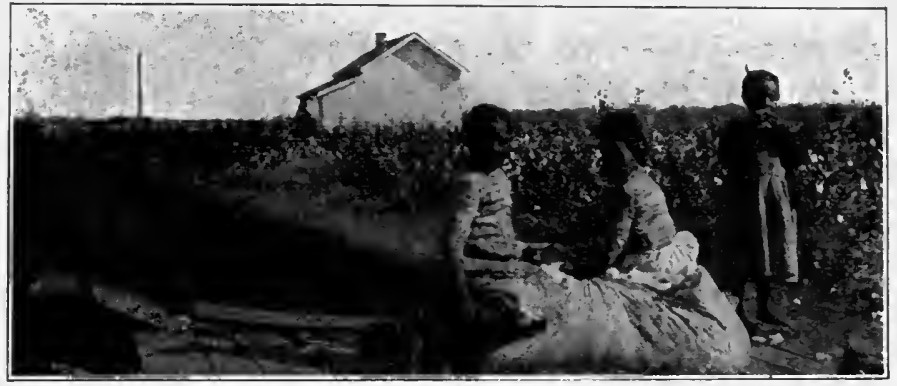

Copsright by the Detroit Publishing $\mathrm{Co}$.

A familiar sight on a cotton plantation.

ing before the introduction of the factories made a combination of geographical and social barriers to the introduction of manufacturing in the Soutl after invention made cotton the basis of clothing, and the South accepted the inevitable and staked her wealth on the production of cotton.

How Cotton Production increased. The Southern planter was now becoming more and more interested in producing cotton and was ceasing to develop the manufacturing even of necessary things for the home. 
Here is a table which illustrates how cotton production increased:

The Cotton Crop in Million Pounds

\begin{tabular}{|c|c|c|c|c|c|}
\hline 1791 & I $80 \mathrm{I}$ & 1811 & I 821 & 1826 & 1834 \\
\hline South Carolina .........5 & 20 & 40 & 50 & 75 & 65.5 \\
\hline Georgia ........... 5 & IO & 20 & 45 & 75 & 75 \\
\hline Virginia $\ldots \ldots \ldots \ldots \ldots$ & 5 & 8 & 12 & 25 & Io \\
\hline North Carolina ........ & 4 & 7 & ro & IO & 9.5 \\
\hline Tennessee...$\ldots \ldots \ldots$ & I & 3 & 20 & 45 & 45 \\
\hline Louisiana......... & & 2 & IO & 38 & 2 \\
\hline Mississippi $\ldots \ldots \ldots \ldots$ & & & IO & 20 & 85 \\
\hline Alabama ............. & & & 20 & 45 & 85 \\
\hline Florida...$\ldots \ldots \ldots$ & & & & 2 & 20 \\
\hline Arkansas....... & & & & .5 & .5 \\
\hline Total ........... 2 & $\overrightarrow{40}$ & - & $\overline{177}$ & $\overline{330.5}$ & $4 J x$ \\
\hline
\end{tabular}

From this table it will be seen that in I79I, two years before Whitney invented the cotton gin, there were purchased in the South only about two million pounds of cotton; but ten years later the amount had increased to forty million, and the year before the second war with England began these figures were doubled. But in I82I, when the new tariff law had been in effect about five years, the production had increased to one hundred seventyseven million.

These figures are interesting from another standpoint. In I79I there were only five Southern States,-_South Carolina, Georgia, Virginia, North Carolina, and Tennessee. These figures, however, do not show how much cotton was raised in the last three states in that year. The next cotton state to be added to the Union was Louisiana, which 
became a state in 1812 . Mississippi came next, in I8I7; then Alabama, in I8I9. It was many years before another cotton state was added. Arkansas came in in 1836 , and Florida in 1845 .

As new states were settled, production increased and the price of cotton fell lower and lower, and greater efforts were put forth to double the output in order that the revenue might be increased.

How the Tariff affected the Cotton States. The tariff of 1816 , which has been referred to in a previous chapter, was an experiment. It brought prosperity to the eastern manufacturers of New York, New Jersey, and Pennsylvania; it favored the western farmers of Ohio, Kentucky, and Tennessee; it increased the wealth of the sugar planters in Louisiana. But the cotton states saw the price of cotton drop from twenty-four cents a pound in 1818 to fourteen and a quarter cents a pound in I820. Since the enactment of this experimental tariff law in $18 \mathrm{I} 6$ the amount of cotton produced had increased about sixty per cent. This increase was one factor in reducing the price. But England was still fighting for a monopoly of the cotton manufacturing business, and when this tariff law was enacted she retaliated and placed a duty on all cotton imported into that country; and the cotton states saw that the tariff law really produced a double hardship, since the law itself discriminated against the South and produced a retaliatory measure in England that affected only the chief industry of the South. Thus it became clearly evident that 
the interests of the South industrially were not identical with those of the other sections of the country.

How Slavery affected the Cotton States. Before the tremendous development of cotton cultivation slavery had few defenders in either section. In I 808 the foreign slave trade was prohibited, with scarcely a dissenting vote from either section. Nothing except the old habits of the people of the South and the fear of the consequence to the white people if the slaves should be set free made the institution of slavery permanent. But after the appearance of the three inventions mentioned above a great change took place. Cotton became the source of the wealth of the South. Large plantations became profitable, and slavery had made them so. Slavery, therefore, became the source of the economic strength of the cotton states. But slavery was as useless to the North, where skilled labor was necessary, as protective tariff was to the South, where slave labor was profitable. When slavery was finally accepted as the basis of prosperity and society in the South the cotton states objected strongly to the North's meddling with the institution in any way, or speaking ill of it in any manner. In the jealousies that arose the North learned to hate the aristocratic slave owner in the South; and the South began to look with contempt on the new industrial spirit of the North.

The line of division between the two sections was now clearly drawn. The national government, 
with its tariff laws, was favoring the North and West; but with its pro-slavery laws it was also favoring the South. And for many years, in adding new states to the Union, if one was added to the South, at or near the same time one would be added to the North, in order that one section might not have a decided majority over the other. But by 1820 the internal development of the Northern and Western states had given these sections a decided majority in Congress.

The natural boundary line between tlie two sections east of the Mississippi River was the Ohio and . the Potomac rivers. But after the purchase of the great territory of Louisiana there was a tremendous migration from both New England and the cotton states to the Western country. Land was cheap; living was easy; comfort was certain. New England farmers were moving westward; poorer white farmers of the South sold out and also moved westward. But what should be the character of the civilization in this great western country? Should the great plantation system of the South, including the institution of slavery, be transplanted into this new territory west of the Mississippi, or should small farms, free white labor, and the village life of New England prevail? Which should control, the slave owner or the industrious Yankee? Here was the first great quarrel between the two sections, and it is easy to see which side each section would take.

If the government took the Northern viewpoint, 


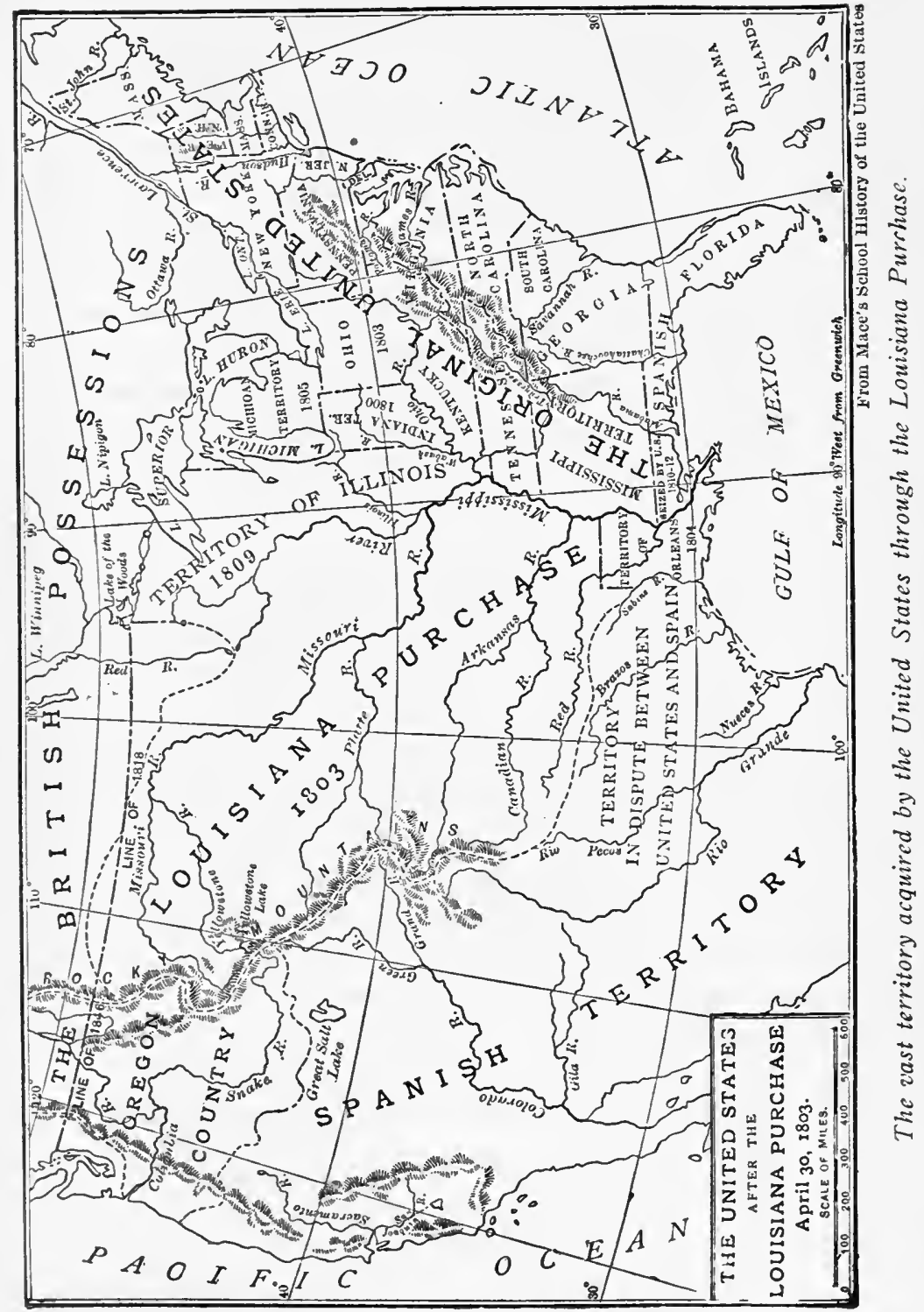


Southern farmers desiring to settle beyond the Mississippi would be unable to take their slaves with them; if the decision was with the cotton states, the New England farmer would be unable to settle there, for white skilled labor and ignorant slave labor could not work together. Whichever section won, its strength in national affairs would be increased; and it was the desire of each section to increase its strength in the government, since the interests of the two were entirely different.

The First Great Political Fight between the States. In 1808 a bill to prohibit slavery passed almost unanimously. By 1820 the cultivation of cotton had caused a wide divergence in opinions. In the North it was becoming the fixed policy to prohibit the spread of slavery in the new states created out of the Louisiana Purchase. In the South the opinion in regard to slavery had greatly changed because, in the production of cotton, slavery was very profitable.

By 1820 the cotton industry had caused a crystallization of opinions in regard to tariff and slavery. It was at this time that Missouri applied for admission into the Union. Should the aristocratic cotton planter control the destiny of this new state or should the new industrialism of the North and East control? Upon this question came the first great fight between the North and the South.

By this time it was seen that the new protective tariff laws were injurious to the aristocratic cotton planter but beneficial to the new industrialism 
of the North and East. If the policy of the government therefore should be opposed to the extension of slavery in this new territory west of the Mississippi, the interest of the cotton states would be so completely subordinate to this new industrial spirit that separation from the Union would be the only logical conclusion. And this opened up another question.

What redress did a state have if its interests were seriously affected by laws made in the interest of the other states? In order to answer this question the statesmen of the time went back and discussed the original rights possessed by the states before they formed a federal union. It was argued that each state originally had absolute sovereignity and that the states voluntarily formed the Union. It was also argued that this sovereignty was not surrendered when the Union was formed, and that each of the states reserved the right to withdraw from the Union. But how was it with Louisiana and Missouri, neither of which was one of the original states, but was formed of the territory which had been bought from France? Neither had original sovereignty, yet Louisiana had been made a state, and Missouri was asking to become one. William Pinkney of Maryland, one of the greatest constitutional lawyers of the day, argued that if these states came into the Union they must have sovereignty bestowed on them.

In order to save the Union a compromise was effected in $182 \mathrm{I}$. This compromise was brought 
in by Henry Clay of Kentucky. Missouri was admitted as a slave state, and the cotton states won. But a line was drawn through the nation, and all the territory south of thirty-six and one-half degrees north latitude was cut off from the rest of the country and labeled slave territory. The cotton kingdom by this act was now sectionalized, with a distinct civilization of its own and a distinct policy different from that of the remainder of the nation. All the rest of the country based its wealth on skilled labor; but this sectionalized portion based its wealth on the production of cotton with the aid of slave or unskilled labor. But the first political battle was scarcely won when the second great fight which was to define the nature of the union began.

The Second Great Fight between the States. The South was sectionalized in $182 \mathrm{I}$. It was clearly seen that if the government gave aid to the manufacturing industries of the nation the South would naturally be discriminated against; for a government can give little aid to unskilled labor. Now the nation was committed to the idea of a protective tariff for the purpose of protecting American industries against similar English or European industries. The tariff law of I 8 I 6 was reënacted in 1824 , with higher protective duties. The bill was brought in by Henry Clay, "the Father of the American System." If the former tariff bill was objectionable to the cotton states the latter was much more so. The former controversy over 
slavery was fresh in the minds of the law makers and the whole question of rights guaranteed to a state was to be reopened. By 1828 , however, Henry Clay of Kentucky gave place to Daniel Webster of Massachusetts as the chief advocate of the protective tariff. This was an evidence that the interests of the North and West were similar. While the tariff was placing a premium on skilled labor in the North and West, cotton was going lower and lower. There were planters who remembered the good old prices when cotton sold for from twentyfive to forty-four cents a pound; but by 1828 they were receiving only nine and ten cents a pound.

The interests of the South, therefore, were different from those of the rest of the nation, and the old idea of state sovereignty and state rights was revived. The great champion of state sovereignty who came forward at this time was John C. Calhoun of South Carolina, who was the author of the notion that a state had the right to nullify a law that was injurious to that state, and that when the constitutionality of a law was questioned, the states, and not the Supreme Court, had the right to interpret it.

This doctrine was stated in a famous speech by Senator Hayne of South Carolina. After this great speech, which reviewed the nullification and secession ideas and the idea that a state was sovereign, it was rumored in Congress that the nation had reached a critical moment again, and none seemed to know "what this constitution is." 
“Then," answered Daniel Webster, "by the bless. ings of Heaven they shall learn this day before the sun goes down what I understand it to be." In his celebrated speech, which was a reply to Senator Hayne, he made it clear to the majority that whatever the original compact may have been, the states by this time formed a union, and a state could neither nullify a law nor peaceably withdraw from the nation. The North and Vest accepted Webster's interpretation, while the South followed the leadership of Calhoun, and in 1832 , when the low price of cotton in the South saw a new tariff in the North which was still more oppressive to the cotton planters, South Carolina moved to nullify the law. For a time it looked as though a revolution had come, but again Henry Clay came forward and introduced a compromise measure which passed, and which put off the trouble to a future day.

The Union had been seriously shaken when the slavery question was compromised; and again it had been greatly disturbed when the tariff question was compromised.

The Relation of the Cotton States to Foreign Countries. The table on cotton production (p. I35) gave the amount of cotton produced in million pounds in the Southern States from the year I79I to 1834 . The following table shows in bales how cotton production increased, how the price was affected, and how much of this cotton was shipped to foreign countries. 


\begin{tabular}{|c|c|c|c|c|}
\hline YEAR & & $\begin{array}{c}\text { NUMBER } \\
\text { BALE: } \\
\text { (500 LBS.) }\end{array}$ & $\begin{array}{l}\text { PRICE IN } \\
\text { CENTS }\end{array}$ & $\begin{array}{c}\text { SHIPPED TO } \\
\text { FOREIGN } \\
\text { COUNTRIES }\end{array}$ \\
\hline I 835 & $\ldots \ldots \ldots \ldots \ldots \ldots$ & $\mathrm{I}, 06 \mathrm{I}, 82 \mathrm{I}$ & I6.5 & 774,718 \\
\hline 1836 & $\ldots \ldots \ldots \ldots \ldots \ldots$ & I, I 29,016 & 13.2 & 847,263 \\
\hline 1837 & $\ldots \ldots \ldots \ldots \ldots$ & $\mathrm{I}, 428,384$ & IO.I & 888,423 \\
\hline 1838 & $\ldots \ldots \ldots \ldots \ldots \ldots$ & I,092,980 & $\mathrm{I} 3.4$ & I,I9I,905 \\
\hline 1839 & $\ldots \ldots \ldots \ldots \ldots \ldots$ & $\mathrm{I}, 653,722$ & 8.9 & 827,248 \\
\hline 1840 & $\ldots \ldots \ldots \ldots \ldots$ & $\mathrm{I}, 347,640$ & 9.5 & $\mathrm{I}, 487,882$ \\
\hline $184 \mathrm{I}$ & $\ldots \ldots \ldots \ldots \ldots$ & I $, 398,282$ & 7.8 & $\mathrm{I}, 060,408$ \\
\hline 1842. & $\ldots \ldots \ldots \ldots \ldots$ & $2,035,48 \mathrm{I}$ & 7.2 & $\mathrm{I}, \mathrm{I} 69,434$ \\
\hline 1843 & $\ldots \ldots \ldots \ldots \ldots$ & $\mathrm{I}, 750,060$ & 7.7 & $\mathrm{I}, 584,594$ \\
\hline 1844 & $\ldots \ldots \ldots \ldots \ldots$ & $2,078,910$ & 5.6 & $1,327,267$ \\
\hline 1845 & $\cdots$ & I,806, I IO & 7.9 & $\mathrm{I}, 745,8 \mathrm{I} 2$ \\
\hline 1846 & $\ldots \ldots \ldots \ldots \ldots \ldots$ & $1,603,763$ & II.2 & I,095, I I 6 \\
\hline 1847 & $\ldots \ldots \ldots \ldots \ldots$ & $2, \mathrm{I} 28,433$ & 8.0 & $\mathrm{I}, 054,440$ \\
\hline 1848 & $\ldots \ldots \ldots \ldots \ldots$ & $2,6 \mathrm{I}_{5,03 \mathrm{I}}$ & 7.5 & $1,628,549$ \\
\hline I849 & $\ldots \ldots \ldots \ldots \ldots$ & $\mathrm{I}, 975,274$ & 12.3 & $2,053,204$ \\
\hline 1850 & $\cdots \cdots$ & $2,136,083$ & I2.I & $1,270,763$ \\
\hline 1851 & $\ldots \ldots \ldots \ldots \ldots$ & $2,799,290$ & 9.5 & $\mathrm{I}, 854,474$ \\
\hline 1852 & $\ldots \ldots \ldots \ldots \ldots \ldots$ & $3,130,338$ & II.O & $2,186,46 \mathrm{I}$ \\
\hline 1853 & $\ldots \ldots \ldots \ldots \ldots$ & $2,766,194$ & I I.o & $2,223, \mathrm{I} 4 \mathrm{I}$ \\
\hline 1854 & $\ldots \ldots \ldots \ldots \ldots$ & $2,708,082$ & I0.4 & $1,975,666$ \\
\hline 1855 & & $3,220,782$ & 10.3 & $2,016,849$ \\
\hline 1856 & $\ldots \ldots \ldots \ldots \ldots \ldots$ & $2,873,680$ & I 3.5 & $2,702,863$ \\
\hline 1857 & $\ldots \ldots \ldots \ldots \ldots$ & $3,012,016$ & 12.2 & $2,092,565$ \\
\hline 1858 & $\ldots \ldots \ldots \ldots \ldots$ & $3,758,273$ & I2.I & $2,237,448$ \\
\hline I859 & $\ldots \ldots \ldots \ldots \ldots$ & $4,309,642$ & II .0 & $2,772,937$ \\
\hline I 860 & .. & $3,84 \mathrm{I}, 4 \mathrm{I} 6$ & I 3.0 & $3,535,373$ \\
\hline
\end{tabular}

In studying these figures it is well to remember that the shipments to foreign countries in any one year were made chiefly from the crop of the previous year. For instance, the crop of 1840 was not gathered until near the close of the year, and the 
shipments were made in the following year. Therefore the large shipment of $1,487,882$ bales in 1840 was taken principally from the crop of 1839 .

A study of these figures, and especially the amount shipped to foreign countries, shows that the South had more interest in Europe than in the other sections of America, since her markets were in Europe. In 1840 Great Britain took one half of the crop, while France took twice as much as New England. Large shipments were also made to Germany, Italy, Spain, Belgium, Russia, AustriaHungary, and other countries. The number of bales shipped to Europe in 1840 was greater than the total crop in 1840 . Trade relatiuns with New England and the other sections of America were therefore a small matter to the South in comparison with the cotton trade with Europe. In 1840 ninety per cent of the cotton crop of the previous year was shipped to Europe.

Since the prosperity of the South was based on the production of cotton, naturally her relations were with those countries which purchased her chief product rather than with the other sections of America, whose interests differed so widely from her own. Therefore trade relations with these foreign countries were of supreme importance to the South, and any law affecting this trade affected the South principally.

English manufacturers and commission merchants stationed their agents at Charleston, Savannah, New Orleans, and other Southern ports 


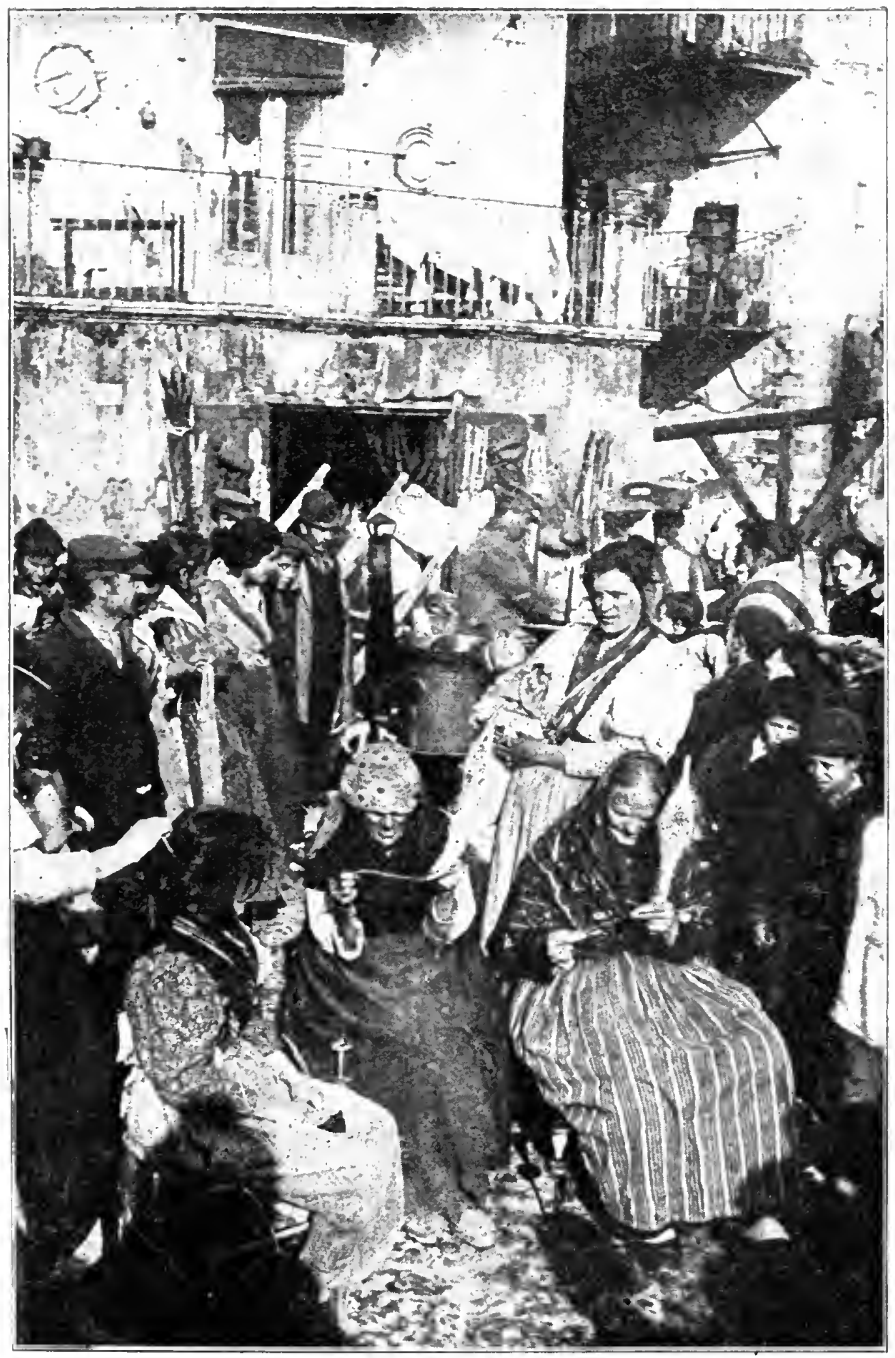

Copyrisht by Underwood \& Unäerwood, N. Y. A street scene in Naples. Note the two women spinning with distaff and spindle. 
to buy cotton. They advanced the money for the gathering of the crop; and a large part of the output was practically owned by Liverpool merchants and brokers even before it was taken from the field.

Cotton production was encouraged above everything else and to the neglect of everything else. All Europe was fast becoming dependent upon the South, and the South upon Europe. So great was the interest in cotton production that with vast areas of primeval forests, mineral deposits, and other natural resources, the South imported goods manufactured from raw material that was going to waste in the cotton states.

How the South turned to Manufacturing. The price of cotton in 1839 fell to a little less than nine cents a pound, and it continued to go down with slight variation until $\mathrm{I} 844$, when it went to a fraction above five and one-half cents a pound. But there were no protective tariff laws then. Since I832 there had been a gradual reduction of tariff rates, and the cotton states had now no quarrel with the tariff policy of the country, but the price of cotton was less than six cents a pound.

It was during this period that the South turned seriously to manufacturing; but the results were not especially encouraging. Poor roads, few railroads, the difficulty of getting the most improved machinery, the inefficiency of slave labor, the contentment of the poor white people with the old spinning wheel, the loom, and the hand ginnies, 
made it next to impossible to start the factory system that was so successful in the North. The Southern States in : 840 consumed $7 \mathrm{I}, 000$ bales of cotton; but this was spun largely on the old spinning wheel and woven on the old hand loom for the use of the slaves and the puorer whites. Here in the land of cotton, where water power was abundant, there was little activity in manufacturing. At this time New England consumed I 58,708 bales. In the whole of the South there were but I 80,000 spindles, a number equal to that found in three or four of the larger factories to-day, while in. New England there were ten times as many.

The Economic Condition of the South. The wealth of the South was in land and slaves. In I 790 the best field hand brought two hundred dollars; in I 8 I 5 , about three hundred dollars. In I 840 the price had risen to nearly one thousand dollars, and by I860 to two thousand dollars. The North and West improved the machinery; the South improved the slave, and to lose the slave meant the loss of wealth and the sources of wealth.

In 1850 the money value of agricultural implements in the South-the great agricultural section -was thirty-seven cents an acre, but in the North it was seventy-seven cents an acre. By 1860 the difference was still greater. In the South it had increased to only forty-two sents an acre while in the North to ninety-four cents àn acre. Unskilled labor : needs few tools. Skilled labor goes from tools to machines, and is ever improving then. 
The great development in agricultural machinery came between 1850 and 1860 ; but the South was affected but lightly by it. She still produced her wealth with the aid of unskilled labor. This is a significant fact. The one-crop system was also ruining the land, and in a period of ten years, from $185^{\circ}$ to 1860 , the land decreased in value.

During this period of territorial expansion the crop statistics show no gain save in the production of cotton. The exhausted soil bore diminishing harvests, and wasted lands everywhere told of the drain upon the South to produce the world's supply of cotton.

Every other section of the country, with the aid of machinery, was fast overcoming geographical limitations and was increasing rapidly in wealth. but in the sectionalized Southern States, cut off by legislative enactment in I82I, and bound down to the soil by unskilled labor, they were enslaved by cotton and the negro workman: and only a revolution could free them.

The industrial development of the North and West had gone far ahead of the development of every cotton "state. The sewing machine had worked a revolution in the manufacture of clothing. Heretofore clothes had been made by hand in the home. Spinning and weaving had been done by hand before the invention of the spinning frame and the power loom; but these-occupations had long since gone from the home, and a new civilization was the result. The sewing machine 
now effected the same result in the manufacture of clothing. But all these distiuct advantages came only to those countries that relied on skilled labor. The sewing machine was also used to a decided advantage in the manufacture of shoes, and the old cobbler, with his thread and awl, began to disappear everywhere except in the South.

The converting of raw material into finished products requires skill and greater skill. Schools must be established to encourage trades and vocations and to give skill and self-reliance. In the South, where labor was performed by ignorant hands, schools were needed to give culture and train for the learned professions. No other education was desired; and universal education was deemed undesirable.

Farming utensils, commercial fertilizers, scientific agriculture, and manufacturing were rapidly increasing and creating wealth in the North and West. These forces built railroads, improved highways, and developed a great commerce which profited much by the cotton production of the South. But in the South the wealth was confined to great estates containing hundreds of slaves engage ${ }^{2}$ in the production of cotton. To destroy the slave would destroy the plantation; to destroy the plantation would cnd the production of cotton and ruin the South.

Cotton production had produced a civilization in the South that was unique in the history of America. Owing to the presence of slavery foreign 
immigration went to the North and West and passed the South by on the other side. As a result the white population coming down from the prerevolutionary settlers was uninfluenced by the millions of Europeans that came into Northern ports.

The South resented any dependence on the North and West, yet the cultivation of one crop increased the dependence. The politics of the country, the industrialism of the age, different social ideals, all hastened the revolution. And we have the third and last great political fight before the revolution came.

The Third Great Fight between the States. Foreign troubles between Mexico and the United States drew the attention from the two great political issues. Texas obtained her independence from Mexico and in 1845 was admitted to the Union, and the United States went to war with Mexico over the boundary line. Mexico was defeated, and in the settlement all the territory between Texas and the Pacific Ocean was ceded to the United States.

Of course when the Missouri Compromise was effected the leaders of the government could not foresee that Mexico would one day give up Texas, New Mexico, Arizona, California, Utah, and a part of Colorado, and that these would one day become states in our nation. Yet this is what happened. California was the first to seek admission. It was both above and below the old Missouri Compromise line. But the Missouri Compromise 
line applied only to the Louisiana Purchase. Should the cotton states form an alliance with these new states, or should the New England antislavery idea prevail? Should California be added to the strength of the Southern cotton states, or should it form a union with the other section of the country?

What should be the attitude toward slavery of these other states taken from Mexico? Should the South remain forever sectionalized and limited? The old bitterness, more intense than ever, was reopened, and again Henry Clay came forward with a proposed compromise, and after a debate extending over eight months, during which time the country was almost plunged into war, the Compromise Bill passed. The result was to open the region of the Mexican cession to slavery, if the states so desired.

The two sections had now fought this issue from the Mississippi to the Pacific Ocean. The hostility was now too great for any enduring settlement. The old leaders that had fought the issues from the first to the last great compromise were now dead, and a new set of leaders had appeared. Abraham Lincoln was preaching the doctrine that a nation cannot exist half slave and half free; and Jefferson Davis was still arguing the sovereignty of the individual states.

As early as $185^{\circ}$ it was really believed that war between the states would certainly result unless the two sections followed the spirit of the last 
compromise. The compromise of I82 I determined the policy of the nation toward the territory in-

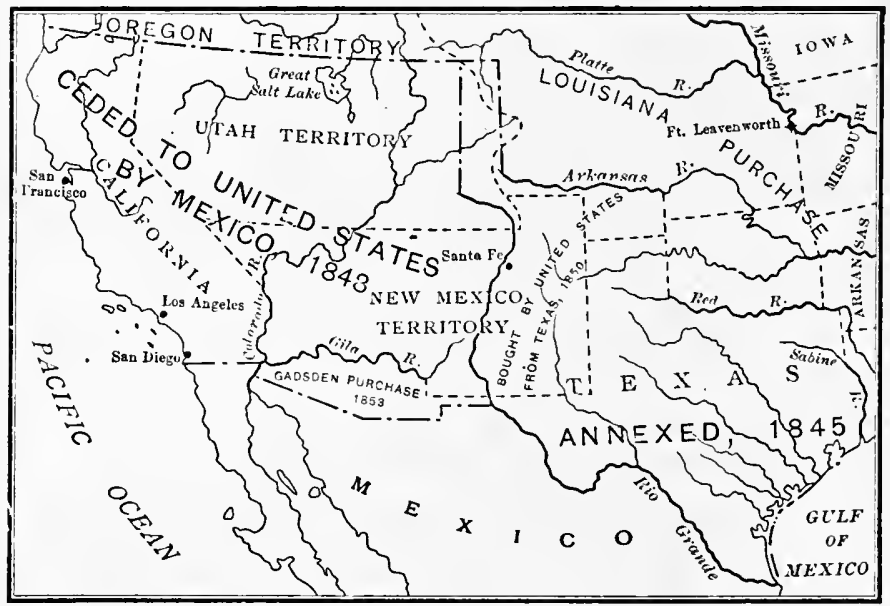

Result of the Mexican War, 1848.

cluded in the Louisiana Purchase, while the compromise of 1850 determined the policy toward the new territory acquired from Mexico. But in 1854 the Kansas-Nebraska Bill was passed making "inoperative and yoid" the Missouri Compromise. Each state was left free "to form and regulate slavery in its own way." The first compromise was now broken. The old slave-trade question that had been settled since 1808 was reopened. There were riots and warfare in the border states. Slaves were incited to rebellion. These acts struck terror to the South. There seemed to be no possibility of the two sections living together in the same nation in peace. Feeling was extremcly intense when 
Abraham Lincoln in I860 was elected President. He had argued ably that the nation could not exist half slave and half free; and he was opposed to slavery. The Southern cotton states decided therefore to withdraw from the Union and set up an independent government where they could regulate the questions of tariff and slavery to suit their own civilization, and the revolution had at last come.

However, before we consider this great revolution that destroyed slavery, broke the cotton kingdom, and created a new civilization in the cotton states, it is necessary to study more in detail the life and activities on the cotton plantation, in order that we may better understand what the South was fighting for, and the nature of the civilization it was endeavoring to perpetuate. The whole world made a heavy demand on the cotton states, and the South had developed an industry that was adequate to the demands of the world; but at the same time it was perpetuating a system which was contrary to the spirit of the world. 


\section{CHAPTER IX}

Life and Activities in the Ante-Bellum Cotton Kingdom

Power measured by its Influence over Men. The first and most elemental desire or demand of any people is a fair and reasonable opportunity to provide food, clothing, and shelter. Out of the struggle for these primal necessities a civilization is gradually evolved. Therefore it is natural that every people with a distinct civilization should endeavor to increase its power and extend its influence, and the extent to which the effort is successful measures the degree of liberty enjoyed by that people.

The amount of power that an individual possesses is measured by his influence over men. Alexander the Great was great not because he was the son of Phillip, King of Macedonia, but because he had unlimited power, by virtue of his own strength, over the conduct of men. Julius Cæesar was emperor, although never crowned, because his strength was imperial. George Washington was the most powerful man in America, not because of his election to many offices, but because he had the greatest influence over the largest number. A man, a section of a nation, or a whole nation rules 
to the extent of the power of each to control the needs and ideals of the many.

Before the Southern cotton kingdom was sectionalized in I82 I, and for many years afterward, the Southern cotton planter had great power, and he shaped the ideals of America. But when the third and last great political battle came the power of the Southern planter was shifting to another section of the country, and a revolution was the result. There is no phase of our social and economic history quite so interesting as the Southern plantation life between the first and the last contest between the two sections of America.

A great plantation embracing twenty or thirty thousand acres and containing several hundred slaves was not hard to find, and managing such an estate was something like governing a small kingdom. The ability to manage men successfully, even though these men are slaves, is an evidence of power. Such an estate, therefore, in the making developed leadership, courage, and initiative; and these are precisely the attributes possessed by the cotton planters of the South.

The Power of the Southern Plantation. The wealth of the Southern plantation was derived from the production of cotton. A plantation aristocracy was therefore developed that was opposed to city building and to the accumulation of wealth in strong commercial centers. The prevalence of this senti. ment made factories and factory life on any large scale impossible. In fact, there was a certain 
expressed opposition to the introduction of the factory life into the Southern States. The ideals of the South were opposed to the industrial ideals of the other sections of the country.

The civilization of the South was based on land and slaves. The land was held in large plantations, sometimes equal in area to half a county, which were cultivated by slaves frequently of sufficient number to equal the population of a good-sized village. Such an estate was usually divided into several farms, and as a rule not more than one hundred or two hundred slaves were quartered on any one farm; but the landlord supervised the whole and received reports from his overseer daily.

On such a plantation order and system prevailed. The servants were assigned to labors which suited their skill and industry. There were field hands, house servants, carpenters, blacksmiths, gardeners, cobblers, stewards, millers, wagoners, weavers, spinners, and engineers. The life, comfort, and happiness of these beings were entirely in the hands of the master and mistress, or, as the slave called them, "Marser" and Mist'ess." The responsibility was by no means small, since the welfare of each slave was a chief concern. This was of necéssity the case, despite the few exceptions that have so often been taken for the rule. Slaves were too valuable to be abused, for one well trained was worth two thousand.dollars in the markets of the South; and if a two-hundred-dollar horse elicited the sympathy and care of the master, certainly a 
two-thousand-dollar slave was of much greater concern. The life of the master or mistress was by

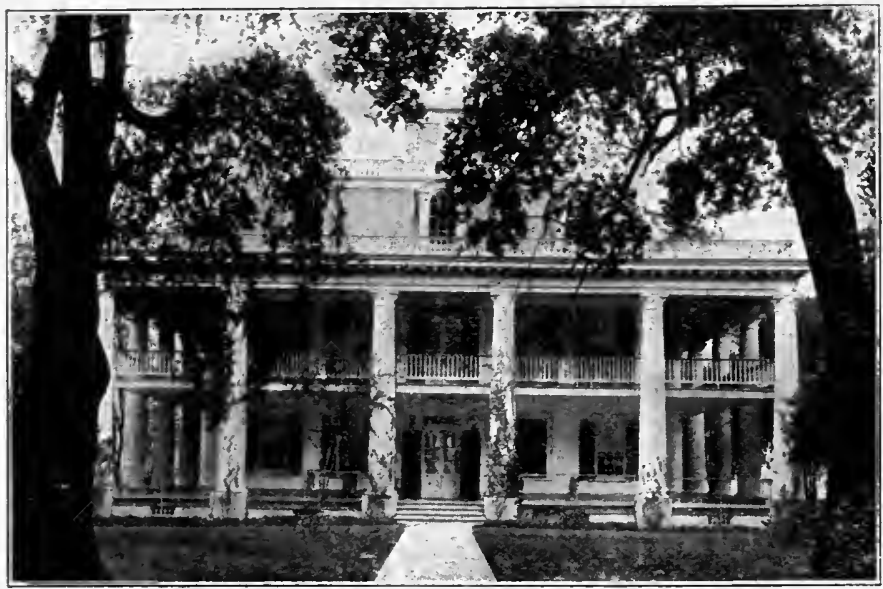

The "Big House" on a great Southern plantation.

no means one of ease and idleness, for so many different activities called for eternal vigilance.

The system of agriculture operated by the planters was usually a financial success. The larger the plantation and the more slaves in service, the greater the returns. The white man loved to control and the negro was easily controlled, but in order to make farming pay, the planter had to live on the plantation and supervise everything in person. And he usually had a home, or the "Big House," as it was called by the slaves, which measured up to his station in dife. He developed the production of cotton to such an extent that he gave the world better, cheaper, and much more 
abundant raw material for clothing than it had ever before enjoyed. He produced more grain, more meat, more home supplies of every kind, per capita, than people in any other part of America, and he developed a system that produced a social life unsurpassed in America.

The Master's Domain. The master, mounted on his favorite saddle horse, rode from plantation to plantation, made inspection, gave directions, and ruled his principality with the authority of a feudal lord. The example of his conduct-his physical courage and integrity-were elements of even greater importance than physical force in controlling his subjects. The slave admired the man who was afraid of nothing and who told the truth. Therefore the qualities of courage and truthfulness became highly developed, and were the cardinal attributes of a Southern gentleman; and to question either of these in any planter meant at once mortal combat.

The chief consideration of the planter was of course for his great cotton fields. It was this that made slavery profitable and the large plantation possible, since the planter who produced cotton with slave labor could usually make money. It was an easy matter to produce the meats of all kinds, since a large estate contained much woodland which supplied natural pasture land for hogs, cattle, sheep, and goats. Therefore with good management the cotton crop would be almost a clear profit. 
The bulk of the cotton was produced by planters who owned from a thousand to three thousand acres of land and from seventy-five to three hundred slaves. In describing the plantation life, therefore, it is the estate of three thousand acres that is considered. On such a plantation, cultivated by about two hundred slaves, the labor was divided about as follows: for the field, fifty plow hands and seventy-five miscellaneous hands, including women; for domestic duties and otherwise, seventy-five women and children, many of whom were non-producers.

The crop was generally laid out on a basis of twenty-five acres to one good plow hand and one mule, so that with fifty plow hands there would be approximately twelve hundred acres under cultivation. Less than half of this acreage would be put in cotton and the remainder in wheat, corn, and oats. Such a plantation would produce the food supply for all its laborers and from two hundred to four hundred bales of cotton. If skill in management was exercised, the cotton would be almost clear profit and worth from fifteen thousand to thirty thousand dollars a year. The value of the estate was measured not by the number of acres of land but by "how many negroes does he own?"

Few things in agriculture are as fascinating as great fields of growing cotton: The tall plants with their long branches spreading and overlapping from row to row, the thick clusters of white and 


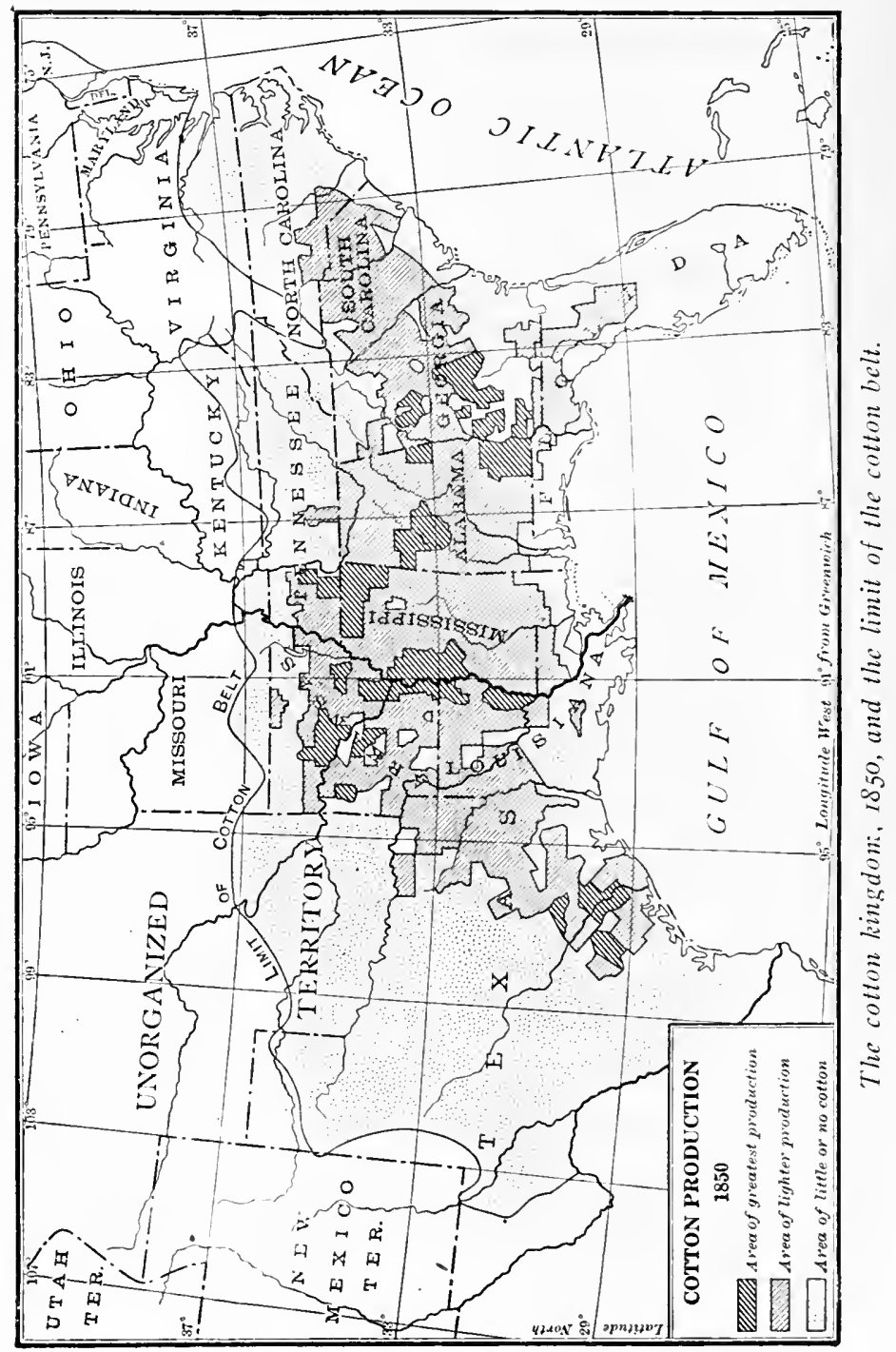


pink blossoms, broad, rich green leaves sparkling and shimmering in the day's sunlight, present a blooming sea of waving, fragrant foliage alive with the quick chirrup of a million insects and the ceaseless droning of the bee. Such a field would produce an aristocrat though none existed before.

The Field Hands. The slaves were divided into "gangs" or groups, usually of about twenty or twenty-five to each. With each "gang" was an overseer, or driver, who was frequently a trusted negro who had reached this most responsible position on account of his ability and fidelity. At sunrise the plantation bell rang, and the plowmen, followed by a larger number of hoe men, women, and young boys and girls, started to the fields.

Before the field work was begun the overseer measured a day's work and staked it off; for nearly all ordinary work was done by tasks. Each hand had his day's work, or task, laid off for him; and he could take his time or work rapidly, as he desired. In hoeing, a task was a certain number of rows; in plowing, it was so much ground, usually about one acre. The overseer did the calculating for each, and when the task was completed, which sometimes happened several hours before sundown, the slave was free for the remainder of the day. The overseer might excuse a hand before the task was completed, if it was more difficult than usual, but he could never extend it. In this way all field work was accomplished.

After about the first week in August the cotton 
became too tall for further plowing. Then the holiday season began and lasted for nearly a month. No more work was required until the blossoms all fell to the ground, the leaves parched and dropped off, and the hot sun burst open the green bolls.

Cotton Picking. The most interesting time of the year on a large plantation was the cotton-picking

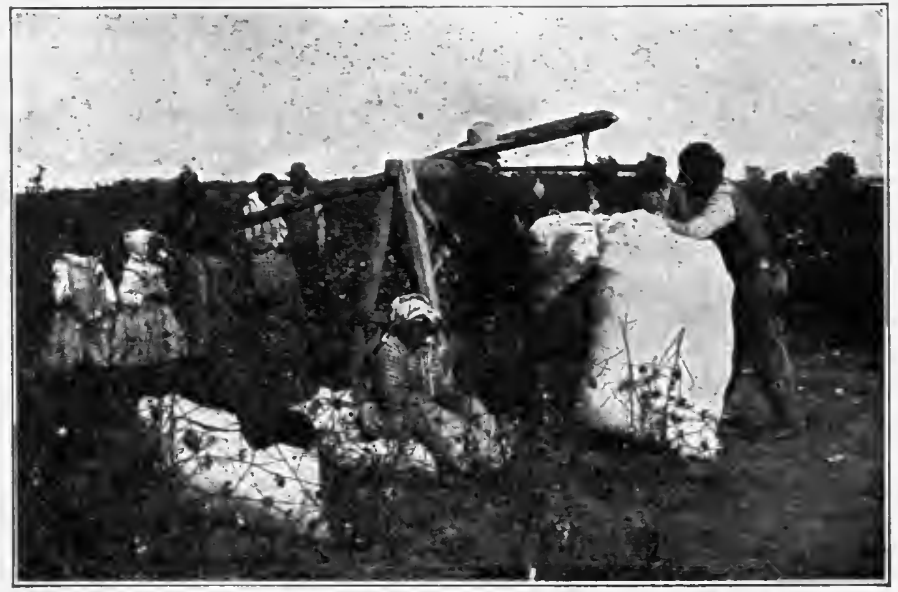

The cotton field at the end of the day's work: weighing the pickings of the "hands."

season, which usually began in September, though sometimes in the latter part of August. Great fields of ripe cotton are always attractive. They meant then as they do to-day thousands of dollars to the planter. Many things were done to stimulate the greatest activity in picking cotton, for the storms that sweep the South in early fall always damage the crop. A system of reward was frequently inaugurated. Prizes of money were 
distributed every Saturday night during the season, and the master gave money to all who worked well, whether they won a prize or not. When one person picked five hundred pounds in a day, a fivedollar goldpiece was sometimes the reward. Usually from one hundred fifty to two hundred pounds in a day was considered a good day's work, but there are instances of six hundred pounds being picked in a day by a single slave.

The negroes were helped in every possible way in picking cotton. Boys carried the cotton hampers to the wagons and emptied them; water carriers with buckets of fresh water went up and down the rows, handing gourds of water to the pickers. It was not unusual for the latter to get so excited over the work that they had to be made to leave the field at night; and some of the very ambitious men would sleep at the end of the rows so that they might be up at daylight and begin earlier than their rivals. Such was the activity in the fields on a well-regulated estate.

The Cotton Gin. After Eli Whitney invented the cotton gin power had to be employed. At first the gin was turned by hand, but before I 820 some one, the individual's name is unknown, discovered a way to use horse or mule power with the aid of large wooden wheels, gears, and levers. Marked mechanical skill was shown in the use of this power.

A large gin house, about fifty by seventy-five feet, was constructed on posts about ten or twelve feet high in order that the wheel gears and levers 
could be operated underneath by horse or mule power. By turning a series of $\operatorname{cog}$ wheels the large wooden wheel was turned which connected with the gin upstairs. All the ginning was done upstairs, but the lint as it left the gin fell to a room below at the rear of the gin house. A large part of the space above was divided into stalls in which the seed cotton was stored, and the large platform in front was for drying the cotton before it was ginned.

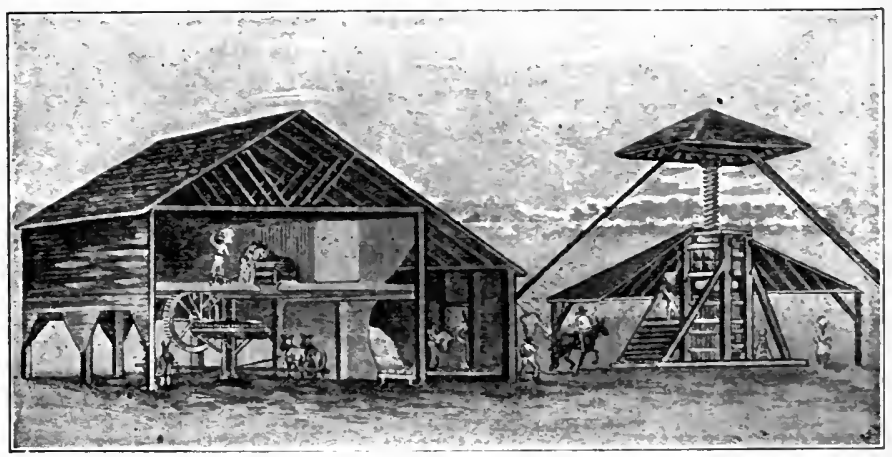

After Fig. 12 in Cotton and Cotton Oil. Courtesy of D. A. Tompkins An old plantation gin house and screci.

The old-time cotton screw may be seen in the picture near the gin house. A rectangular box about twice the size of a bale of cotton was built, above which, resting on heavy posts, was a tremendous wooden screw which was adjusted to a floor just the size of the opening in the press box. Attached to the top of the screw were two strong beams which straddled the press like giant legs and extended toward the earth. At the end of each beam was hitched a mule that pulled the screw 
round and round and caused it to move slowly downward into the press.

In those slavery days it required several hands to unload the cotton from the wagons or to carry. the baskets upstairs to the gin room. One slave stood at the gin and led cotton into it; two or three slaves, white with lint, would file out of the lint room with large armfuls of cotton and dump it into the press; two or three more would stand in the press and trample the cotton down until enough was in to make a bale; and one or two boys were employed to drive the mules around until the pressing was complete. Finally, they drew the bagging around the pressed cotton and tied it securely with ropes. The cotton was now ready for market, and the Liverpool agents and commission merchants were waiting for it.

The Wagon Drivers. This activity at the gin began as soon as the picking season opened, and soon many bales lay carelessly around. Wagons drawn by four and sometimes six mules were kept running regularly in the market season, each wagon carrying from four to six bales. As the returning wagon drivers came up in the evening they were met by other men who loaded the wagons for the next day. The distance to market was usually very great, frequently requiring two or three days to make the trip to market. Some plantations were located near steamboat landings, however, and the hauling was easy.

Driving a team of mules was considered quite 
an art. Only a few could do it, but to-day here and there lives a trusted colored man, old and stooped, his hair white like wool, his voice now weak and feeble, who boasts of the time when he drove his master's loaded wagon and cracked his whip over a team of six mules.

The Steward. Next to the overseer the most important official on the plantation was the steward, or watchman as he was sometimes called. He was a very respectable looking slave of superior endowments. He carried a large bunch of keys suspended from his waist and had charge of all the stores of provisions, tools, and materials of the plantations, as well as of all the produce before it was shipped to market. $\mathrm{He}$ weighed and measured all the rations for the slaves. His responsibility was in fact much greater than that of the overseer of the farm.

In distributing rations for the week, for all the slaves had to be fed, he usually allowed each person three pounds of pork, one peck of meal, one quart of molasses, a pound of tobacco, and two pints of salt. Clothing was likewise distributed. The usual allowance a year was two suits of clothes, one pair of blankets, from one to two pairs of shoes, and an overcoat for the drivers. Most slave families made something extra from their gardens, or by their skill in hand work. Slaves were great hunters, too, and knew the habits of the rabbit, the squirrel, the wild turkey, the fox, the raccoon, and the opossum. 
The Cobblers. Another great task was to make shoes for all these negroes. From two to three hundred pairs had to be in readiness. Hides were taken from the cattle when they were slaughtered and tanned and packed away for the cobblers. Two or three old negro men, too feeble to be of great service in the fields, sat day and night at their benches, making and mending shoes. They plied the awl and hammered pegs, and as the shoes were completed they were put away in a storeroom for use in winter. Sometimes the planter permitted the shoemaker to make a pair of shoes for the poorer white people in the community, and sometimes these old shoemakers would work at night making or mending shoes for poor white people, retaining what they made from this extra labor to use as they saw fit.

Carpenters, Wheelwirights, and Blacksmiths. With so many houses to build and to repair and so much wooden machinery in use, there were necessarily carpenters and wheelwrights who followed these occupations exclusively. So skillful did they become that they could make any necessary repairs or any addition to the Big House. On so large an estate there were as many as three and sometimes four regular workmen. The carpenters' shop stood near the barn and stables, and there wagons, plows, and all kinds of necessary things were made; for the shop was complete, and the head carpenter was not only skillful but very valuable. 
Near the carpenter shop was the blacksmith shop. The forge and the anvil and the old negro with his leather apron were familiar objects. He usually had an assistant or two, for he was busy making horseshoes, mending plows, wagons, and wheels, or doing other repair work which came in his line.

Other Activities of the Slaves. On a plantation of this size such stock as cattle and hogs were divided; and there were several feeding stations, for stock all ran at large, and the fields were inclosed with zigzag rail fences. Morning and evening an aged negro could be seen, his cart filled with corn, going to one of the many feeding stations where hogs and bullocks knew when to meet him.

Boys were kept about the plantation ready to ride for the mail, or carry messages over the plantation or around the neighborhood. In fact, there was no lack of such boys to fill every place for which they were competent. The trouble was rather to find work for all of them, especially when the fields were not calling them. They played with the master's children and administered to their every need. Thus from infancy the two races were taught the relationship of master and slave.

As has been intimated, the slaves were given opportunities to make money for themselves. They raised chickens, peanuts, and popcorn, and made baskets, mats, brooms, and chairs. Some of the women took in sewing, for most of them 
knew something about the use of the needle. On rainy days the women were usually brought into the house, where the work given them to do was making dresses for the children and mending their own clothes.

When the tasks were completed the negroes could spend the remainder of the day working for themselves. Adjoining each cabin was about half an acre, or an acre, of land allotted to it. Here grew vegetables, watermelons, fruits, and frequently cotton. The negroes were at liberty to sell what they made, and as a usual thing the master bought a large part of this produce, paying the market price. The master usually kept a store on the plantation well supplied with such articles as the slaves needed or desired most. He sold to them regularly. When they had something to sell, he usually paid them in money or merchandise. When they had nothing, but desired to buy, he charged it against them on his books. Thus a credit system was begun which assumed great proportions after the war.

The Duties of the Mistress of the Plantation. The master had many slaves to consider, and his overseer gave him full reports each night; but the mistress also had her duties.

Between anxiety over her own children and the responsibility of overseeing such a large house-hold, superintending so many servants, and p!anning for their comfort summer and winter, the life of the mistress was one of constant toil-not 
drudgery, but that executive work calculated to develop a woman of great initiative, courage, selfreliance, and of fine leadership. Those who did not possess this capacity for such work were lost to the world and dropped down into a life of endless routine, which was but little superior to the slavery of the slaves who did the drudgery of the house.

The mistress of the house had her special servants. Three or four of the strongest and most capable of the colored women had charge of the laundry. These were perhaps the busiest women on the plantation. Usually about six or ten seamstresses were employed in the house to make clothes for the many slaves and their children. Patching, darning, and sewing were also done for the women in their cabins.

One of the chief persons in the Big House was the cook. Sometimes this indispensable person was a man, but as a rule a woman of known reputation. The cook always had a scullion or two to help, besides a man to cut wood and put it on the huge andirons, for there were no cook stoves in the earlier days.

On such a plantation there were between twenty and thirty cows to milk. Three or four women were in charge of the milking, while another did the churning and looked after the butter. Negro boys looked after the cows, which ran at large in the forests. Usually two boys mounted on horses or ponies drove them up, kept them separated 
from the calves, and saw that the calves were well fed. The poultry, including chickens, ducks, peafowls, guineas, and turkeys, was usually intrusted to the care of a responsible woman.

As several hundred slaves had to be clothed, the large weaving room was always busy. Two or three active women were kept constantly at work, weaving on as many looms. All day long you could hear the click of the shuttle and the knock of the heddle as the women wove the cloth. Several more of the women were carding cotton and operating the spinining wheels, for thread had to be provided for the weavers. Others were preparing the bark of the trees and the berries that had been gathered for dyeing the thread, which young women with quick fingers were engaged in warping. These women carded, spun, dyed, and wove for the whole number of slaves. They provided cotton cloth for the women and men in summer, jeans for the men, and linsey-woolsey for the women and children in winter.

There were usually three or four girls who slept in the house and had the care of the rooms. The number varied according to the number of the master's children, for each child had a servant. Finally, there was the old negro butler, who kept the door knockers and the floors polished and served his mistress in a hundred ways.

Such was the activity on a large, well-regulated plantation. Food and clothing were supplied on the plantation. With so many slaves there was 
little need for importing, except the luxuries. Machinery, the use of steam, and the higher forces that science had contributed were useless in the hands of negro slaves. There were enough hands to do all that was needed to be done, and the cirilization was complete in itself. Each plantation was a complete organization, and so different was it from the business organizations of the Nortl and East that there could be no sympathy or harmony between them.

Life and Comfort of the Slaves. But, you ask, were the slaves happy, did they have any amusements, or was their life one of grinding, hopeless toil?

On an old plantation, and their number was legion, where the slaves had been in the tamily for generations, where the master guarded their interests and would not permit the families to be separated, and where none was sold except occasionally a vicious slave, there was an attachment for "Marster" and "Mist'ess" and a unity of plantation. life that could not be destroyed even by the great war, for here the slaves did not care for freedom and would not have it when freedom came. The master, knowing this full well, resented any insinuation that slavery was a curse.

The cabins down the lane were full of amusements, and there was a community life far superior to the squalid negro quarters of the towns and cities of to-day. The slaves lived in cabins each usually containing one room, but sometimes two. 
or three rooms.- the size depending upon the size of the family. They were at first built of logs,

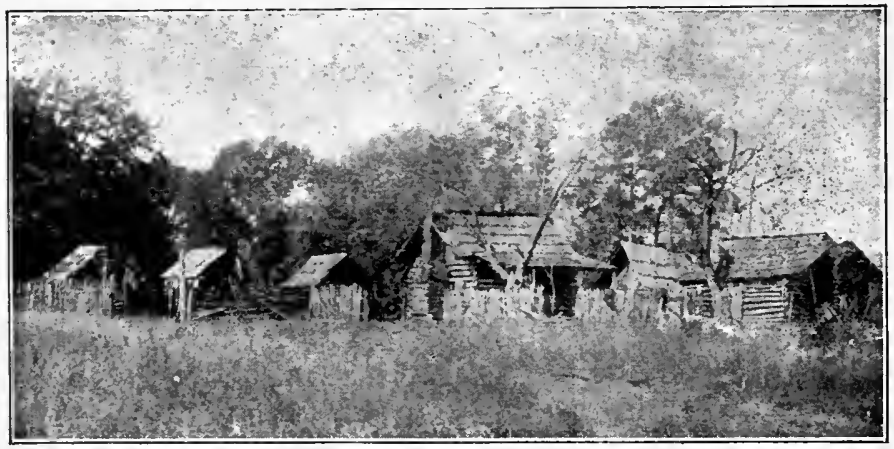

Courtesy of Doubleday, Page \& $\mathbf{C o}$. Slave quarters on a plantation under the old régime, now in ruins. but later, when the sawmill came into use, they were built of plank, and sometimes of brick. They were located on a lane that ran into the big road, and in rows about a hundred to three hundred feet apart.

The master or mistress inspected the homes regularly, and insisted on sanitation. The white sandy walks leading up to the doors were bordered with pinks, phlox, bachelor buttons, princess feathers, buttercups, and many other flowers. It was to these cabins that the children of the master came to hear old negroes like Uncle Remus tell tales of ghosts and animals. Hither also came the small boy, and learned to make his bird trap, to set a rabbit gun, and to twist a rabbit out of a hollow tree. The welfare movement in the cottonmill sections to-day had its antecedents in the 
solicitation that every humanitarian master and mistress exhibited for the health and comfort of the slaves.

The cabins down the lane did not lack amusements. Parties were given. On Saturday nights and Sundays there was an exchange of visits from neighboring plantations. There was marrying and giving in marriage, and at their nuptials members of the master's family attended and supervised the "infare." Negroes with their banjos and fiddles, who frequently played at the Big House, where the cotillon or the Virginia reel was the favorite amusement of the young people, made music while the servants danced and sang until the night was nearly spent.

The master was usually a great hunter. A pack of well-trained hounds was very valuable. It is recorded that a pack of ten hounds has sold for as much as two thousand dollars, and a single lead hound for as much as three hundred dollars. In the fall of the year fox hunting, deer hunting, coon hunting, and opossum hunting were favorite pastimes; and master and slave followed the call of the hounds and rode side by side in the chase.

Relation of Master's Children to the Slaves. All children, whether white or colored, were taught to call the old negroes "uncle" and "aunt," a custom that is partly retained in the South today. These were titles of respect, and negroes in those days resented being called by their names without the title, and considered it a mark of ill 
breeding when this custom was violated. The negroes called each other "brer" and "sis," such titles having reference not to natural but to church relationship.

Many a bright slave was taught by the mistress to read and write, and these in turn sometimes became the instructors of the master's children. A few of these slaves rose to some intellectual prominence, during the days of slavery; and not a few prominent white men can trace the beginnings of their education to the instruction received from these servants.

While the mistress taught a few, the children of the mistress taught many: Those who were willing and had the ability sat with "marster's chile" and learned to spell and read stories from books. Sometimes they were gathered together in the kitchen while the children "played school.". The young and the middle-aged came together, and lined around the wall were the aged as spectators. Grown men with their big black fingers pointing at words in the spelling book stood near the youthful teacher, who exercised authority after the manner of ancient days when the rod was not spared; for the young pedagogues frequently. belabored the backs of the sturdy delinquents. Such instruction was received with shouts of amusement, and the clumsy scholars dodged about from corner to corner in their efforts to escape the smiting rod, while the cook, the carriage driver, and the butler looked on, roaring with laughter. 
A few slaves learned to read well. These as a rule became teachers of the others. For this service the master usually paid them in eggs, chickens, or money. The children were constantly with the servants. They rode together, played together, and frequently ate together; for again and again would the little children slip away to the cabins about mealtime and run joyfully into the arms of "Old Auntie," who would pull a hot, smoking potato from the ashes, peel it, and place it in the child's hand. In fact, she knew the child would soon come for it. The attachment was so strong that ministering to the children of the "mistress" became a sacred obligation. This fidelity was exhibited when the trusted one sat the night through holding a feverish form close to her bosom, never tiring or complaining; and if love and fidelity constitute any basis for a future morality and efficiency, there is hope for the negro race.

Attachment of Master and Servant. Thus master and servant were ever together. Many of the planters even thought too much of their slaves to hire them out, and some would have thought almost as soon of selling their own children as of selling a faithful servant. A kind master never mistreated his slaves. They were too valuable; the wealth of the plantation depended upon them. His kindness to them was of such a nature that many servants who were offered their freedom for faithful services frequently refused it, preferring 
to remain with the master and in servitude forever.

It is well known that when an epidemic of cholera swept over a part of the South masters refused to flee, and after sending their children away to places of safety, themselves remained at home to wait on the afflicted slaves, giving them medicine and nursing them through the affliction.

Attending Churches. When the community was thickly settled and churches were sufficiently large the master and his servants attended the same church. On Sunday morning the- master and his family would start in their carriage, accompanied by a negro on muleback to take the horses on their arrival at church. Then came the negroes in wagons, on muleback, or walking. Covering about one third of the church, at the end opposite the pulpit, was a gallery which was occupied by the slaves, while the master's family and other white people were seated below. The old custom of separating males and females applied alike to both races. As a rule the negroes outnumbered the whites and were as well dressed as the poorer white people.

Such were some of the dominant characteristics of the great plantation life in the days before the war; and an inventory of such an estate would show a value amounting to several hundred thousand dollars. A few estates were probably worth more than a millon.

Some of the Evils of the Plantation System. Nature fitted the South to be the home of the 
negro. Neither section originally had any choice in the matter. The negro came to America at a time when the world recognized slavery as a legitimate institution. He was enslaved soon, if not immediately, after his arrival, and became the basis of an extensive slave trade which was a profitable and, according to the standard of the times, a lawful business. He came to America naked, ignorant, savage, and speaking an unknown tongue. He found a home in the South, where a warm climate and fertile land made it possible for him to prosper. The strict authority of the planter and constant association with a superior race drew him up from savagery to a respectable plane of moral, intellectual, and industrial efficiency. In the earlier days freedom for him was impossible, for in his semi-savage state the life, liberty, and happiness of the white race would thereby have been endangered. Consequently the system of slavery grew with the plantation system. Under the circumstances slavery was at that time beneficial to the negro, although in many respects harmful to the white race. It hindered the industrial development of the South, and put the South out of harmony politically with the remainder of America; it formed the basis of a social order that was aristocratic and very expensive; it caused a line to be drawn through society, placing on one side the aristocratic slave owners and on the other side the poor white people who were in many instances 
looked upon with contempt by the slaves themselves. Owing to these social divisions thousands of poorer families moved into the West and the Southwest, where land was cheap and society less severe.

The plantation system developed a few good carpenters and mechanics, but the method of farming was very poor, very expensive, and destructive to the land. The effect of slave labor on the land was a gradual wearing out of the soil. Large plantations absorbed the richest land, and many acres of worn-out and unimproved land were the result. Thousands of acres of old field pine in the South to-day tell of the poor system of farming; and miles upon miles of washed-away hillside give evidence of neglect and ill treatment of the land. We should remember, however, that there was very little scientific farming anywhere in America when the plantation system of the South was at its best. But with the appearance of improved farming utensils and commercial fertilizer the planters of the South remained backward and were content to throw away worn-out land and clear away the forest for virgin soil.

\section{A New Civilization Hostile to Civilization of the} South. The North and IVest, by use of machinery in manufacturing and the improvement of tools and machines and methods used in agriculture, had developed a new civilization, the basis of which was skilled labor and an industrialism which made possible the production of great wealth. A 
new force was coming down the century, and it was coming out of the North and West. A new empire was being created-the empire of business. Invention had made it possible for one man to unite thousands of skilled laborers and to control their activities. This new capitalist power had thus gained the ascendency in the nation and was limiting the influence of the Southern planters,was in fact using the product of the Southern plantations to increase its influence. These two

- great forces met in Congress, and the capitalistic industrialism won. Slavery and the activities of slavery were contrary to the spirit of the civilization of the nineteenth century, and the institution had to go. This was inevitable anyway, for the South was now reaching a point where there would soon be no new land to clear, and slave labor was incapable of using improved machinery and practicing intensive farming. Before the supply of land had been finally exhausted, however, slavery was abolished in a revolution which broke the power of the South and destroyed the great plantation system. 


\section{CHAPTER $\mathrm{X}$}

\section{The Fall of the Cotton Kingdom}

A Recapitulation. There were two great opposing forces at work in the nation, a new industrialism and the old landed aristocracy. Which would ultimately rule? Repeated attempts were made to keep a perfect equilibrium between them. But it is contrary to progress for two opposing forces to develop and at the same time maintain a perfect equilibrium. The first fight came when Missouri asked for admission into the Union. A compromise was effected that was designed to maintain this equilibrium; but in reality it completed the sectionalizing of the South. The second fight came when tariff legislation was disturbing this equilibrium. Another compromise was effected which had for its purpose the restoring of this equilibrium. But the North and West were growing faster than the South; and natural growth would in itself disturb this equilibrium. The third fight came over the new territory acquired from Mexico.

The application of California for admission to the Union brought the question to an issue. Henry Clay proposed his last compromise measure in an effort to settle the question as the others had been settled. John C. Calhoun, who had led the fight for the 
Southern cotton states now for nearly half a century, was still in the senate, but was too feeble to speak, and his address on Clay's proposals was read by another senator. He said: "If you admit her [California] under all the difficulties that oppose her admission, you compel us to infer that you intend to exclude us from the whole of the organized territories, with the intention of destroying, irretrievably, the equilibrinm between the two sections."

This act which the South feared was evidently what the nation was planning to do. The Sonth, though she had held for a long time the primacy in the nation, was defending an issue which the civilized world had already repudiated, with the result that she was losing her ancient prestige.

The Cotton States set up an Independent Government. Whèn a new party rode into power in I860 and elected a new leader, Abraham Lincoln, whose anti-slavery convictions were already well known, the South saw the handwriting on the wall. The equilibrium between the two sections had, in the opinion of the Southern leaders, been destroyed, and the South claimed the right to withdraw from the Union and set up a government of her own. "All we ask is to be let alone," said Jefferson Daris when he retired from the senate. "Let us depart in peace," said Robert Toombs in his farewell address ; "refuse that, and you present us war."

In that same year the cotton crop, the largest up to that time, was $3,84 \mathrm{I}, 4 \mathrm{I} 6$ bales and about ninety- 
two per cent of this amount was shipped to England and the continent of Europe in this year. The world's supply of clothing came largely from the South, and a million souls in Europe were dependent upon industries which were supported by her cotton. Cotton was the king that would decide the issue. The governor of South Carolina said that the world did not dare make war on the cotton states, and many of the leadars of the South believed that the world was so dependent upon the Southern States for cotton that no nation would make war on them; and should the North declare war, it was believed that the European nationsespecially England and France-would interfere.

Did a state have the right to withdraw from the Union? This question had been argued for years. Jefferson Davis in his farewell address to the senate of the United States said, "There was a time when none denied it." But in I861, when these words were uttered, there were many who denied it. However, seven of the leading cotton states, South Carolina, Georgia, Alabama, Florida, Mississippi, Louisiana, and Texas, withdrew at once from the Union and organized a new government, making Montgomery, Alabama, the capital and electing Jefferson Davis of Mississippi as the first president. On the same day that Abraham Lincoln was inaugurated President of the United States the Confederate flag was flying over the capitol at Montgomery.

The New Constitution. The constitution which 
the seceding states speedily adopted expressly affirmed the right of property in negro slaves, and made mandatory on Congress the recognition and protection of slavery in any new territory that might be acquired. This constitution also forbade Congress to lay duties on foreign goods shipped into the new nation for the purpose of protecting or aiding any branch of industry. Thus the two great issues that had caused so much bitterness for nearly a half-century were settled in the Confederate States by the constitution; and two governments, where there had before been only one, were fairly started off.

Would there be War? The world undoubtedly needed the cotton of the South, but slavery was contrary to the spirit of the age. The South, however, believed that the abolition of slavery woutd end the plantation system and destroy the production of cotton. Therefore the new government wrote its faith in slavery into the constitution in spite of the fact that the civilized world beyond the boundary lines of the cotton kingdom had expressed its disapproval of the institution. By this action the South deprived herself of foreign allies in case of war, for European nations would not fight for slavery.

The larger interests of the other manufacturing countries caused them to be very friendly to the success of the South, and opposed to the industrialism of the North; but the nations of the world were opposed to slavery. Here was a world-wide moral 
issue. The North, for the time being, passed over the moral question and denied that a state had a constitutional right to withdraw from the Union, thereby making the act of the South rebellion. The Sonthern States, in turn, argued they were not fighting for slavery but for their ancient and constitutional right to withdraw from the Union. In this latter argument the South had the advantage. The real issue behind the argument, however, was whether slavery should be perpetuated, though the North fought two years and was all but defeated before this moral question became the chief point at issue.

When it became evident that the Northern States would make war on the Southern States it was readily seen that the border states would be the battle ground. What should these states do under the circumstances? They could not remain neutral, and consequently they must choose sides. Naturally they chose the side of the South, where their interests were greater and where their friends and relatives lived. These border states were Virginia, North Carolina, Tennessee, and Arkansas. After the admission of these four states to the new confederation its capital was moved to Richmond, a more central location.

The South relied on Cotton for Revenue. But war means, besides men, great sums of money for provisions, clothing, arms, and ammunition. Where was the South to get the money for these things? Cotton! The world must have it. Many of the 
leading men of the new nation trusted implicitly in the commercial and industrial supremacy of cotton. And fifteen million dollars was raised at once on cotton. Some urged that all cotton be seized by the government and held as security for bonds or confederate money; others proposed that there should be an agreement with Great Britain by which she should have a monopoly, or the exclusive benefit of the Southern trade for a period of twenty years. More money was needed as the war went on, and one hundred fifty million dollars was raised on cotton, then another one hundred fifty million dollars. But alas! all efforts to ship cotton to foreign countries soon failed, for the North was blockading the ports of the South, and the South had few vessels of any kind. Partial relief was found by levying a tax in kind upon other farm products, such as sugar, molasses, tobacco, rice, wool, hides. beef, pork, and bacon.

The Cotton Famine. The cotton crop of 1859 . which was shipped in I860, supplied $3,535,373$ bales to the foreign markets, and England took one half of it. In r86i Europe was able to secure only about six hundred thousand bales, and the next year only about ten thousand bales.

The Northern factories were suffering as well as the European factories. In I86 I both began looking for cotton elsewhere. But where could it be found? The West Indies and Brazil sent about sixty thousand bales to the Northern factories, but this was a mere handful in comparison to the one 
million, five hundred thousand that was necessary for the Northern mills. The bulk of the cotton

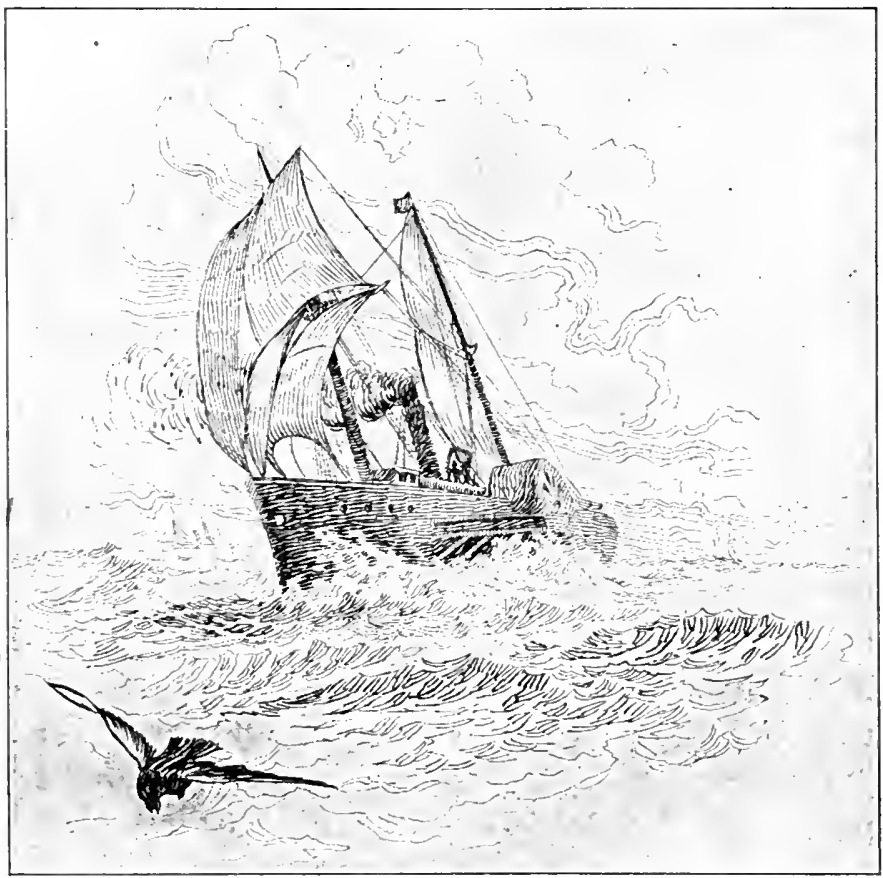

From Mace's School History of the Inited states A blockade runner loaded with cotton on its way to English cotton factories.

was shipped to Europe. There three million, five hundred thousand bales were needed but only ten thousand were able to leave the ports, and these had to run the blockade.

The Confederate States thought that England's want of cotton would induce her to send a fleet and break the blockade; that she would not hesitate to 
do this when her manufactured goods were admitted free. England said in reply, "We do not like slavery, but we want your cotton." At the same time she said to the North, "We dislike very much your tariff laws." The following rhyme went the rounds of the papers of England:

"Though with the North we sympathize,

It must not be forgotten,

That with the South we've stronger ties,

Which are composed of cotton.

Whereof our imports mount unto

A sum of many figures;

And where would be our calico

Without the toil of niggers?"

In its effort to force the European nations, and especially England, to lend aid to the South, the Southern Confederacy made numerous attempts to stop the exportation of cotton, knowing that the factories of Europe were dependent upon the cotton of the South. An Embargo Act was passed. This seems to be a favorite weapon for modern nations engaged in war, but the history of the measure, without exception, proves that it is disastrous to the country levying the embargo, for it cuts off the only avenues for securing supplies from the outside world.

This and other acts, however, were lightly regarded by the states, since vessels made frequent trips to the ports of Europe. Overland trade was carried on with the North, although frequent attempts were made to stop it. Bale after bale of cotton was smuggled into the North, and it became 
the source of many supplies to the South. In the second year of the war about twenty-three thousand bales were shipped out of the South.

The South, however, did not have to worry long over this embargo, for the blockade of the Southern ports became a dreadful fact.

A Cotton Famine the Hope of the South. The first two years of the war showed that the North and Northwest were not in entire sympathy with the policy of the government to force the Southern States back into the Union. The Southern troops were so successful that more than once the national capital was in jeopardy. Horace Greeley of New York, always opposed to the war on the South, interested the Franch Minister in Washington, and, through him, Louis Napoleon, the Emperor of France, who offered to mediate between the two sections. But it was in the Northwest that the feeling was strongest. The want of cotton, which affected every one, and the closing of the Mississippi to the trade of the West, together with the heavy taxes and the stagnation of business, caused some of the states to consider seriously recognizing the South and withdrawing from the Union.

While the war raged with the fortunes of war decidedly in favor of the South, the factories, especially of France and England, were in great distress. In July, I862, Slidell, the confederate Commissioner to France, offered the emperor a hundred thousand bales of cotton if he would send 
his ships to break the blockade. Europe badly needed four million bales, and this would solve the problem. The emperor was favorable to the proposition and made an offer to England and Russia that they "exert their influence at Washington as well as with the confederates to obtain an armistice for six months."

Russia and England declined. Two months later the distress in the cotton manufacturing districts of France became acute. More than a hundred thousand workmen in one department alone were out of employment and in a condition of utter misery. At this critical time Slidell again gained an interview with the emperor, who had already determined to move alone, whether Russia or England joined him. The government at Washington declined to accept his policy of intervention, and the emperor did not have the courage to proceed further.

While England declined to join France in any move toward ending the war, at the same time the distress among the mill operatives in England was increasing daily, and the demand for cotton was imperative. The situation was so critical that. according to the American Minister, "a word from the Prime Minister, suggesting that the time had arrived for recognition, would meet with unanimous response in the affirmative."

As the winter of I862 came on, the distress increased both in England and France, for whole towns were dependent upon factories that used 
Southern cotton. Hundreds of thousands of employees were without work, and visions of starving families and frozen children were driving them into a state of frenzy.

The Trade Routes to the South cut off. You will recall the great distress that came to Europe when the trade routes to India were cut off by the Mohammedans. Then the wealthy suffered most, but now the trade routes to the cotton kingdom of the South were cut off, and the distress was greatest among the laboring classes.

The fact that this war was carrying distress to the whole world showed that cotton was still king. How remorselessly this monarch levied on the world when his kingdom was invaded! In the North and West there was the wildest alarm, and secession was encouraged. France was in distress, and was turning to the other nations for sympathy in her efforts to end the war; England was in distress, and only a word from the Prime Minister was needed; and the South was uniformly victorious in battle. Such were the conditions at the close of the year I862; King Cotton, having been molested, had disturbed the equilibrium of the world.

But the crisis in the cotton trade was about to pass. The distress in the manufacturing districts was soon to be relieved, and the issues of the war were soon to change.

Old Trade Routes to India reopened. At the close of the year I 862 three hundred thousand bales 
of cotton arrived from India. Egypt, Siam, and Brazil, together with India, began to pour their cotton into Europe. Generous people in the North, sympathizing with cotton operatives of England in their distress, sent shiploads of provisions that stayed their hunger. Soon, therefore, the distress of England became less acute. With the opening of the new year President Lincoln declared all slavery in the United States at an end. The issues of war were thus shifted; Europe would not fight to perpetuate slavery, and the cotton states were left to their fate.

The Fall of the Cotton Kingdom. Gettysburg was fought, Vicksburg was lost, the Mississippi River was opened to the traders of the Northwest. and the ports were blockaded securely. Useless cotton was piled high in Southern markets. Even in this condition it served as a financial reserve; for in I864 Jefferson Davis, speaking of the resources of the South and the paper money that had been issued, said, "If every dollar of it were lost, we should, as we have no foreign debt, be none the poorer. But it is worth something; it has the solid basis of a large cotton crop." But an effective blockade was bringing disastrous results to the South.

Even at this late date cotton piled up in the South was serving as security. Notwithstanding the blockade, the success of the Southern army in Virginia under Lee kept the North in constant terror and served to strengthen the confidence of 
sympathizers in Europe, who continued to advance money on cotton.

The cotton states had not encouraged manufacturing, and to prevent the cotton falling into the hands of Union armies hundreds of thousands of bales were burned. Supplies of all kinds were running short; food, clothing, arms, and ammunition were hard to obtain. The cotton kingdom was being starved to death, and the end of the war was inevitable. Secession, slavery, the old plantation system, all expired at Appomattox.

The fight between the two sections that had been carried on for half a century had ended in a revolution, with the result that in the South the whole social order had been overturned, and the old plantation system destroyed.

It was in the spring of 1865 that the surrender came. It was imperative that a new crop be made, for the people of the South were in destitute circumstances. This fact influenced General Lee when he proposed to surrender and end the war. His heart was troubled over the conditions in every Southern home. General Grant, appreciating the situation, gave instructions "to let all men who claim to own a horse or mule take the animal back with him to work the little farms." Four large armies had marched through the South. Buildings and provisions had disappeared, gin houses had been burned, cotton, horses, and mules had been carried away, and the negroes had been set free. There were slender prospects for reviving 
the old plantation life. As a rule the negroes welcomed their masters on their return, and many learned for the first time that they were free. The old slaves had stayed with the women and children during the war. They raised provisions for them and the troops in the field, and kept the old plantation in order as best they could. They had been intrusted with the horses and cattle, and the valua-

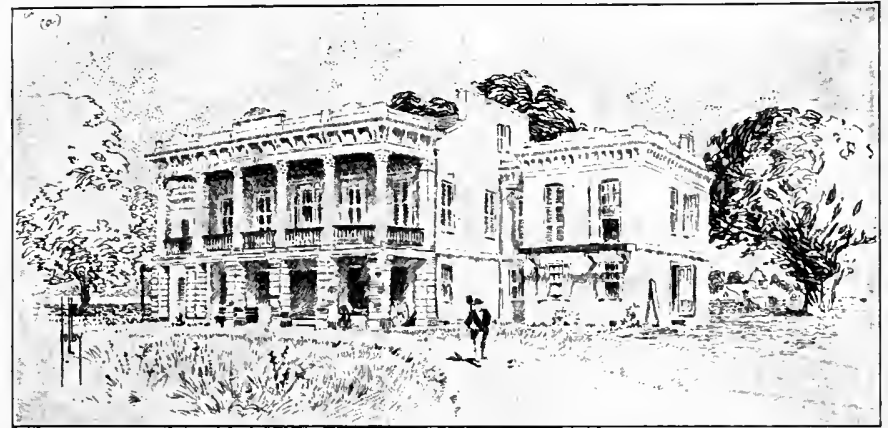

The abandoned home of a Southern planter: A relie of the ante-bellum days.

bles of the home. But the sweep of great armies had wiped the country almost clean.

In this distress a few had preserved some cotton, which was now bringing fabulous prices, in some -instances selling for more than a dollar a pound. And the high prices received for the few bales not confiscated by the government saved many sections from total ruin and the inhabitants from starvation. Many an old-time negro now tells how he hid a few bales of cotton in the swamps while a foreign army was plundering the country. 
The Effect of the Fall. The slaves were free; great farms were in ruins; many of the landlords had been killed in the war; magnificent homes had either been destroyed or were soon abandoned and left to decay. Leading families, reduced to poverty, found it necessary to give up their large country estates; and little remained to testify to the social splendors which existed before the war, when the landlord ruled like a feudal baron and dispensed a hospitality that was magnificent. All the way from the Potomac to the Rio Grande dilapidated mansions typify the fast fading memory of a once powerful civilization that for many years ruled the nation. The colored man of to-day nust find his genesis in that period. His schools and colleges, his industry and prosperity, his morality and religion, his faith and hope, point always to the middle period when "Ole Marster" and "Ole Mist'ess" of the plantation bore his burdens as he traveled from naked savagery to enlightenment. But Appomattox ended the old civilization of the cotton kingdom, and a new era soon began. 


\section{CHAPTER XI}

Building a New Civilization in the Cotton KingdOM

Economic Adjustment during the War. It is a long story from I82I to I 865 , but it is a continuous story; and it is largely a political story of national and international importance. In 1865 , however, the end came and the conclusion was written. The cotton kingdom lost out politically in the nation; and it is a difficult matter for any people that have once been thoroughly discredited to regain power. Political questions after I 865 were settled without reference to the cotton kingdom, and a new adjustment had to be made.

The strength of a people shows itself in the ability of the people to overcome economic, social, or political environments. To be able to change an environment, to overcome geographic limitations, is a mark of superiority.

Cotton was the one staple produced in the South before the war. Everything was based on it. Suppose we notice, therefore, the following table. which gives for the war period the number of bales of cotton produced, the number of bales shipped to foreign countries, and the price received per pound. 


\begin{tabular}{|c|c|c|c|c|}
\hline Year & & $\begin{array}{l}\text { No. Bales } \\
\text { PRODUCED }\end{array}$ & $\begin{array}{c}\text { No. BALES } \\
\text { EXPORTED }\end{array}$ & $\begin{array}{r}\text { PrICE IN } \\
\text { CENTS }\end{array}$ \\
\hline I 861 & $\ldots \ldots$ & $4,490,586$ & 615,032 & 31.2 \\
\hline 1862 & $\ldots \ldots \ldots \ldots$ & $1,596,653$ & 10,129 & 67.2 \\
\hline 1863 & $\ldots \ldots \ldots \ldots$ & 449,059 & 22,770 & 101.5 \\
\hline 1864 & $\ldots \ldots \ldots \ldots$ & 299,372 & 23,998 & 83.4 \\
\hline 1865 & $\ldots \ldots \ldots$, & $2,093,658$ & I 7,789 & 43.2 \\
\hline
\end{tabular}

The cotton crop of $\mathrm{I} 86 \mathrm{I}$ was the largest produced up to that time. The war began in the spring, even before the old crop had all been moved; for only 6I 5,032 bales of the crop of 1860 were exported to Europe. By the time the crop of I86I was harvested, trade relations had been cut off and the cotton kingdom had little else but cotton. Since it could not be shipped, there must have been approximately six million bales of cotton unsold and unsellable in the South by the close of the first year of the war. It served as security for European loans, but the South had to raise foodstuff also. The hardships of the war, therefore, taught the cotton kingdom for the first time to diversify the crops, and it is said that in April, I865, when General Lee surrendered, there was sufficient foodstuff piled along the railroads and river banks to supply the army with rations for nearly a year; but it was practically useless on account of the lack of transportation facilities.

\section{A Nèw Social Adjustment after the War. War} changes the habits of a people. After the Revolutionary War and the second war with England. America relied less on England and became selfsupporting. The Civil War changed the habits of 
- the Southern people and made them rely on their own skill and energy for every necessity of life. Where there was no skill, attempts were made to develop it. The cotton kingdom, with a monopoly on raw material, had been in the habit of buyng largely both clothing and other manufactured necessities in foreign markets; and when the war stopped foreign trade the habits of the people received a severe shock. But now the war was over, and it seemed for a while that the old régime would be revived, with some adjustments to new conditions.

The planters and their sons returned just in time to put in their crops for another year. Labor was necessary, since neither the planter nor his sons had ever worked in the fields, this task being reserved for slaves or poor whites. But the negroes were free, and a new relationship had to be established. To ráise cotton without their labor was thought to be impossible, and the high price of cotton, as shown in the table on page I99, was most attractive to the impoverished landlords. The negroes were requested to remain on the plantations and were offered either wages or a share in the crop. Most of them accepted the terms, since freedom was such a new, strange thing to them that many did not understand its full meaning. In fact, many of them heard of it for the first time when their masters returned from the war.

The relationship thus inaugurated was friendly in the main, and in many cases the oldConfederate 
soldiers opened schools for the negroes and had them instructed in the elementary arts. Some of the returned soldiers even acted as school masters, and there was little prejudice or enmity between the two races. The faithful old negroes, who had taken care of the mistress and the children and had provided food for them while the master was fighting to make their slavery permanent, were now willing to continue working for their masters.

Under this new relationship both landlord and laborer or tenant farmer went to work, and the first year the cotton crop reached $2,093,658$ bales. The demand for it was so great that the price ranged from thirty to fifty cents a pound, and the South was in a fair way to regain her lost prosperity. So successful was the first crop under the new régime it appeared that the old plantation system would continue with little change.

The Break-up of the Plantations. The next year the cotton crop was poor. Large productions in India, which had been stimulated by high prices during the war, caused the price to fall considerably. In addition to this, Congress levied on cotton a tax of three cents a pound and allowed no drawback on exported cotton; and by 1870 the price had fallen to seventeen cents a pound. This state of things, together with increasing political and sectional feeling, suddenly checked the recuperation of the South.

Hardly a year had passed before the effect of freedom upon the freedmen began to be felt. No 
longer subject to the will of their masters, the negroes were fast losing their old habits of industry. The value of farming lands, which had been very high, fell fifty per cent. Crops were so poor, and the decline in the price of cotton so great, that planters were unable to meet their obligations, and soon they were compelled to throw their lands upon the market at whatever price they would bring. The change had begun. Even by i 867 the South was in distress agriculturally, and stay laws were enacted to prevent total ruin. Following this in I 868 came the reconstruction policy of the national government. Military rule began, the white planter was disfranchised and his negro slave was put in power. The negro began to rule before he knew how to live; he began to make laws before he knew how to make a home. A new kind of warfare began-secret, and terrible because it was secret. In addition to being a war against the methods of the new government, it was a warfare between masters and their former slaves. A new order had made its appearance, however, even before the last chapter of the old plantation system was written.

The Era of Small Farms begins. Even before the Civil War the wasteful system of farming, and the wide hospitality and expensive living of the planters, encumbered the large estates. A good cotton crop brought prosperity; a poor one, debt and mortgages. At the cotton ports of the South agents of cotton dealers of the North advanced large sums of money to the planters. Cotton firms 
in Liverpool and Paris also furnished large sums of money to aid the planters in moving the cotton crop, the greater part of which went to Europe. A great deal of the land was already worn out, since the planters employed practically the same methods that were used when the cotton gin was invented. Without crop rotation or a knowledge of fertilizers, they tilled the land until the natural soil was exhausted, and then proceeded to look for and "clear" other "new grounds."

The breaking up of the old plantation was now inevitable. Large mortgages, the exhausted state of the fields, the primitive methods of cultivation used, and the unreliability of the new free labor, all contributed to make cotton growing under the new conditions unprofitable. When the plantations were thrown on the markets the buyers were largely Northern emigrants and middle-class white tenant-farmers, all the members of whose families had been accustomed to work in the fields. The Northern settlers, tempted by the low price of land and the high price of cotton, had come in in considerable numbers, but they knew little about the cultivation of cotton and were unable to manage the unreliable negro labor. Moreover, the natural aversion of Southerners to Northerners that had bought their lands for a song and were also attempting to introduce new notions of race equality, did not tend to encourage immigration from the North. Therefore as the old plantations were put. on the market, usually in sections, and sold, 
the middle-class natives gradually came into possession of them. Some of the old planters moved to town to seek employment and to educate their children; others invested the capital realized from the sale of their plantations in merchandising or manufacturing. But the mania for cotton growing had now seized the new landowners who, since their families worked in the fields, were not entirely dependent on negro labor. Land was cheap, and the merchants were willing to advance money on the security of the growing cotton crop. This new class of farmers, therefore, gave agriculture in the South a new life.

Unsettled Labor Conditions. The disintegration of the large estates of the ex-slave owners proceded surely and swiftly. It was the one great rural movement that revolutionized the social life of the cotton states in the first fifteen years after the war. The small planters learned by degrees to rely less and less on negro labor, yet it was inpossible to raise cotton without it. They could manage very well until the harvesting season came, but cotton had to be picked by hand. There was no way around it, for in three months, usually from about the first of September to December, the fiber must be gathered from the fields, and, since it requires more laborers to gather the crop than to cultivate it, the negro was an absolute necessity.

To complicate matters still more, there was a great exodus of the negroes from the South to 
the North, West, and Southwest. Labor agents, taking the place of the old slave trader, went from state to state, organizing the negroes, making contracts with them, and taking them away in trainloads. They moved from the border states to the extreme Southern states, then back again; they moved from the extreme Southern states to the West, then back again; they became dissatisfied, uncertain, and unreliable. The call of the large turpentine forests, the era of railroad building, the development of the Mississippi Valley, the opening of the IVest, the labor agitation, the restless, roving spirit of the negroes, all contributed to make the supply of laborers uncertain, and thus to disturb economic conditions.

The internal political strife due to reconstruction came to an end in 1876 . By this time the new plantation life was fast adjusting itself to the changed conditions. But the negro, cruelly misled by his political friends, was much longer learning his part as a freedman and citizen of the republic, and nearly two more decades were destined to pass before he became a landholder to any considerable extent. He went to work in a shiftless manner as a tenant, receiving half of the crop if the landowner furnished team, tools, and fertilizer; or two thirds or three fourths if he furnished these things himself. Wherever he worked he followed the training received before the war and ignorantly ruined the land. Having nothing to begin the year with, the landowner or some merchant 
had to "run him." That is, he was supplied with food and necessary things until the fall of the year, when the crop was harvested. Usually he was in debt at the end. The farmer took all he made and lost the remainder of the debt if the negro cared to move to some other plantation. There grew up in this way a ruinous credit system which, begun in slavery, has come down to the present day. The credit system contributed to the decay of the larger plantations. The small merchants sold goods on time, charging larger and larger profits and taking mortgage on both tenant and landowner to secure his debts. Therefore the statute books of the Southern States are full of laws dealing with chattel mortgages, crop liens, and other methods of collecting what is due the merchants.

The Rise of the Merchant Class. The merchant demanded cotton, since it had a ready money value and was easily handled; hence tenants and farmers produced cotton to the exclusion of necessary foodstuff, which the merchants could not handle so easily. By this arrangement the merchant could also sell more foodstuff for the next year, with the result that the farmer kept going deeper and deeper in debt. If it were a year of bad crops, or if the price of cotton went down, as it did in I898, the farmer, being hopelessly in debt, was completely at the mercy of the banker or the wholesale dealer. Therefore anything like a panic produced ruin. 
The disintegration of the large farms went on until now the land of the South has almost entirely changed hands since the war, and a new class of landowners has come into existence. During the first fifteen years after the war the average size of the Southern farm was reduced from three hundred seventy-five acres in 1860 to one hundred fifty-three in I880. From I880 to I900, although there was little reduction in the size of the farm a great change in the nature of the ownership did

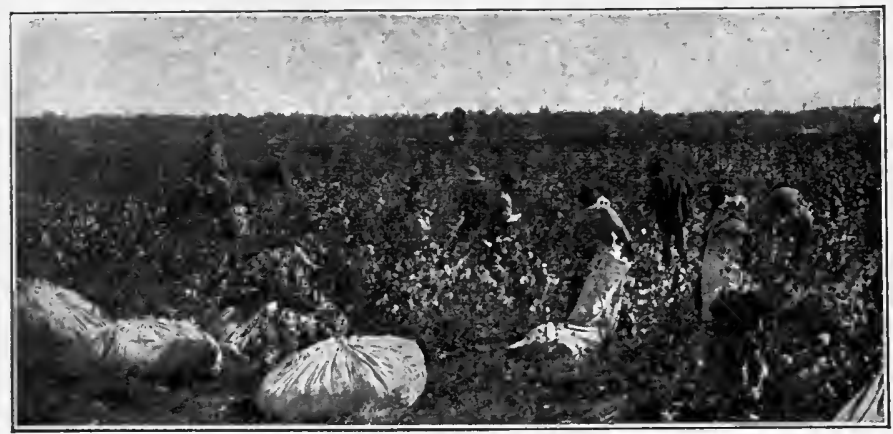

Copyright by the Detroit Publishing Co.

Cotton picking season on a great plantation.

take place. The number of landowners who reside on the plantations decreased considerably, and the tenant system increased accordingly. Much of the land came into the hands of the merchants, the manufacturers, and various corporations, both domestic and foreign. These new owners have lately shown a tendency to consolidate their holdings. Yet in North Carolina, for example, the average size of the farm has decreased since I900 from IOI acres to 88 acres in I9IO. 


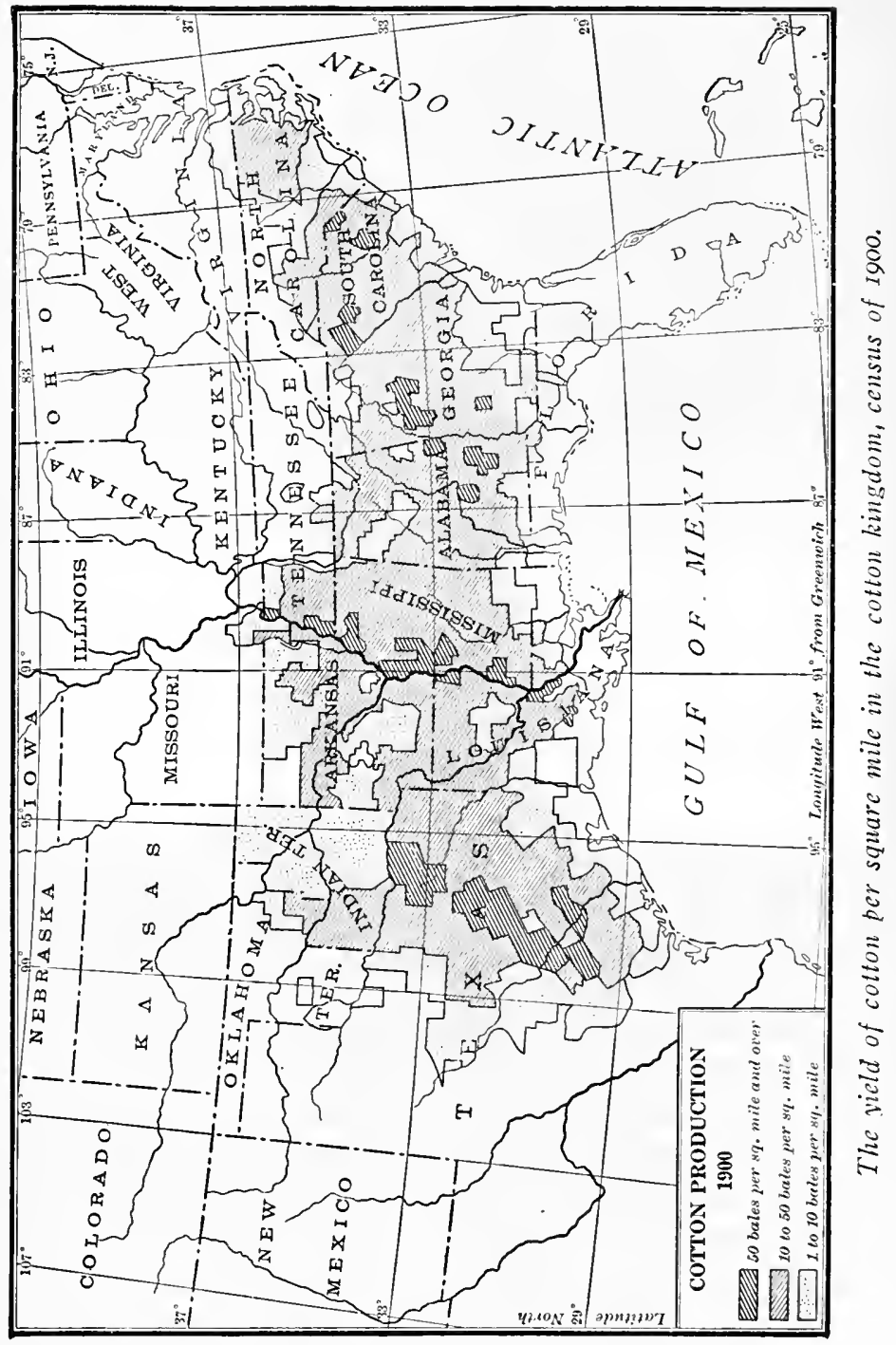




\section{The Dependence of the World upon the South.} The following table shows how cotton production has increased since the war and to how great an extent the world is dependent upon the South:

\begin{tabular}{|c|c|c|c|c|c|}
\hline YeAR & $\underset{\text { Produced }}{\text { Bales }}$ & $\begin{array}{c}\text { BALES } \\
\text { IMPORTED }\end{array}$ & $\begin{array}{c}\text { Price in } \\
\text { Cents }\end{array}$ & $\begin{array}{l}\text { Cotton } \\
\text { Consumed } \\
\text { IN AMERICA }\end{array}$ & EXPORTED \\
\hline I870 & $4,024,527$ & $\mathrm{I}, 8 \mathrm{O} 2$ & I7 & 796,6 I6 & $1,987,708$ \\
\hline $\mathrm{I} 875$ & $4,302,818$ & 4,498 & I3 & I,098, I 63 & 2,504, I I 8 \\
\hline 1880 & $6,356,998$ & 5,447 & I I.3 & $\mathbf{I}, 500,683$ & $3,742,752$ \\
\hline 1885 & $6,369,34 I$ & 8,270 & 9.4 & $\mathrm{I}, 687, \mathrm{I08}$ & $3,730,170$ \\
\hline I 890 & $8,562,089$ & 45,580 & 8.6 & $2,518,409$ & $4,928,867$ \\
\hline 1895 & $7,1_{4} 6,772$ & I I 2,00 I & 8.2 & $2,983,66_{5}$ & $6,961,372$ \\
\hline I 898 & I I $, 435,368$ & 103,223 & 4.9 & $3,472,398$ & $7,839,467$ \\
\hline 1900 & $10,266,527$ & I I 6,6 Io & 9.3 & $3,687,253$ & $6,22 \mathrm{I}, 54 \mathrm{I}$ \\
\hline 1905 & Io,804,556 & 133,464 & 0.9 & $4,523,208$ & $9, I_{9}, 6 I_{4}$ \\
\hline 1908 & I $3,5^{87} 7,306$ & I65,45I & 9.2 & $4,493,028$ & $7,779,508$ \\
\hline I 909 & $10,315,382$ & I 5 I, 395 & $\mathrm{I} 4.3$ & $5,198,963$ & $8,889,724$ \\
\hline
\end{tabular}

The export of cotton to foreign countries in 1870 was only about half as much as in 1860 , and it was not until i 880 that the amount of cotton exported from the South equaled the amount exported in I860. A five-year war affected the cotton trade of the South for twenty years, and for the time it ap. peared that the cotton fields of India and Egypt might supply England with cotton in such quantities that she would never again be so dependent upon the cotton of the South. In I880, however, practically every nation in Europe had established the cotton factory, and the skilled laborers of Europe were employed in making cotton goods. This activity increased the demand for the cotton of the South, and by 1900 the exports to Europe from the South had increased a hundred per cent. During 
this period of twenty years the growth of the manufacturing in the United States, and especially in the South, increased the demand for Southern cotton more than a hundred per cent.

In 1895 there were about three hundred fifty thousand bales of surplus cotton in the hands of American cotton mills. From I 895 to 1900 over six hundred thousand bales of foreign cotton were imported into the United States. In the meantime India and Egypt showed considerable activity in producing cotton, and for the time it appeared as though the manufacturers in Europe and in America would control the price of cotton. By I900, however, the surplus cotton was exhausted; the manufacturers had lost control of the supply. Therefore the price steadily advanced until cotton was selling for eighteen cents a pound. The average price for 1909 was fourteen and three-tenths cents, the highest average price received since 1874 .

The Problem of the South. How can the South meet the demands of the world for raw cotton and at the same time remain economically independent? In attempting to solve the problem, the South is building a new civilization. If she can maintain a monopoly of the clothing material of the world, and at the same time remain independent of the world by producing her own foods and converting the raw material of her soil and forests into finished products, the politics which will be favorable to the remainder of America can never again discriminate against her. 


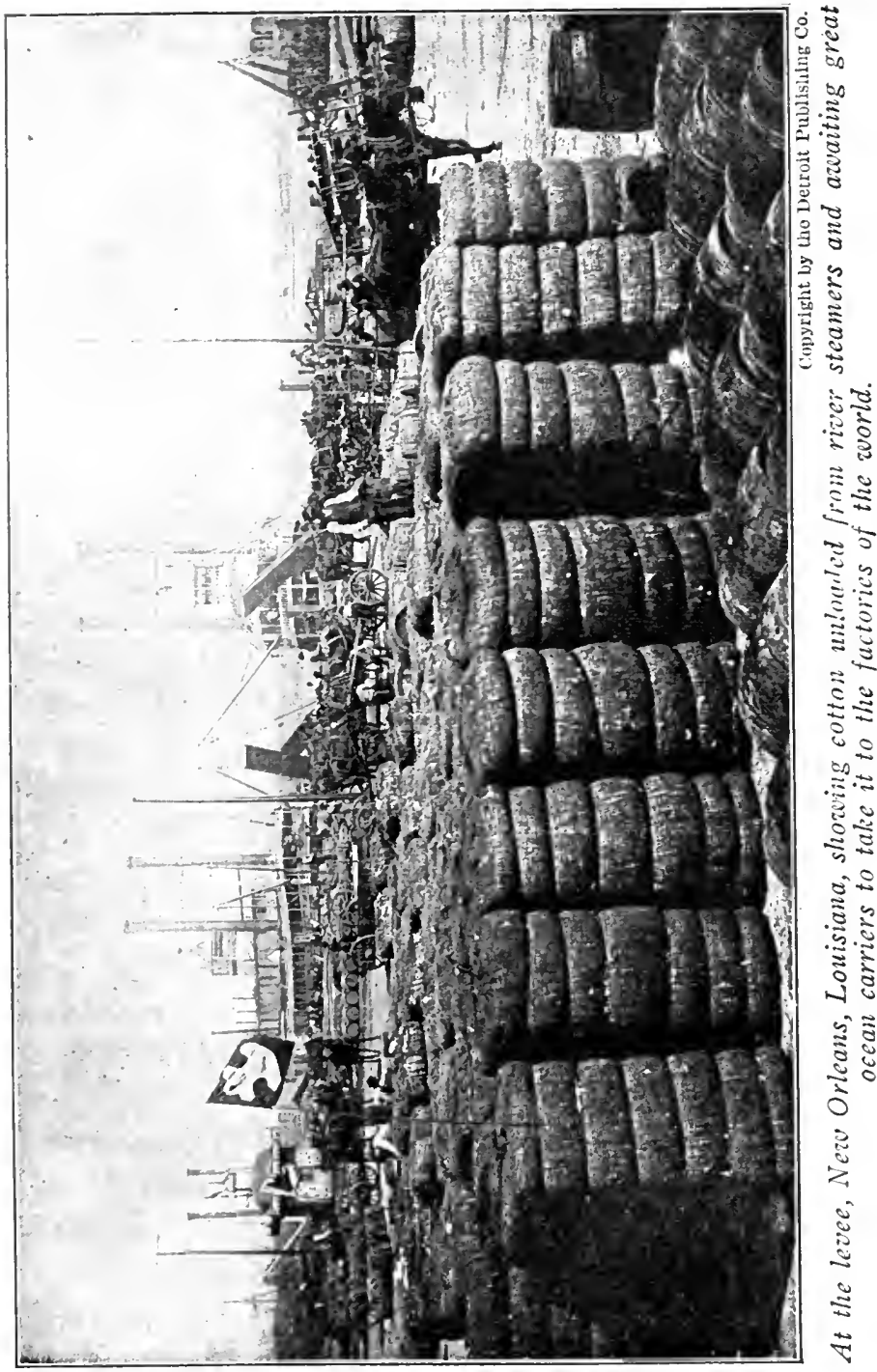


What Nature has done for the South. In I 82 I the South was sectionalized and cut off from the rest of the nation. She had helped to cut herself off because of her peculiar social and industrial life. Instead of overcoming these conditions, the cotton states became subservient to them and only a revolution could free them. At the close of the war, having used very little of the natural resources, except the land, the cotton states had the following assets :

I. Land which had been ill treated but which had unlimited possibilities for improvement.

2. A Piedmont section with much undeveloped water power and with a white population that had been cut off from communication with the outside world because of a lack of internal improvements.

3. A monopoly of cotton production, but dependent upon the rest of the world for all manufactured goods.

4. Every variety of climate, owing to the seacoast and mountain ranges, that can be found from Maine to Cuba.

5. The largest body and the greatest variety of hardwood timber to be found in the United States.

6. Phosphate beds for fertilizer; clay, marble, and granite for building material; coal for fuel; iron for tools and machinery; rock salt, sulphur, mercury, silver, petroleum, natural gas, and asphaltum; besides a variety of other minerals.

Nature has endowed the cotton kingdom with these resources. It has also furnished a variety of 
climate and soils sufficient to make the Southern States independent in foodstuff and to give them a monopoly in cotton, which is the basis of clothing for the whole civilized world. Not only that, but it has deposited beds of phosphate to be used in fertilizing the soil as soon as the-virgin fertility is exhausted. It has given an upland country with wholesome, invigorating climate, and a water power and coal supply to enable the inhabitants of the cotton kingdom to convert all the raw material into finished products and to levy tribute on the rest of the world. It has given iron, clay, granite, and marble and hardwood in sufficient quantities to supply every tool and machine, all building material and household furniture that either necessity or luxury might demand. It has deposited salt for the table, petroleum and gas for illuminating the homes, and medicinal plants for the afflicted. All these were practically undeveloped when the war came.

\section{What has Man done with these Gifts? Nature} rarely furnishes the finished product. Something is left for man to do. What has man done with these gifts? The North American Indian roamed the coastal plains, the Piedmont sections, and the mountain regions of the South for a thousand years, never seeing his kinship with nature or his opportunity for using the gifts of nature. When the white man came he was compelled to move on and give up his hunting ground, where nature had fed, clothed, and sheltered him for so many centuries, 
and to turn over these natural gifts, undisturbed, to a superior race. What has this superior race done with them?

In these natural resources the South has found the basis of a new educational system, a new economic policy, a new social order, a new civilization, and a new power. Before the war the South was in the tidewater section, and the plantation was the source of its tremendous power. Since the close of the war the center of wealth has moved to the Piedmont sections. Converting the raw material that comes from Mother Nature into finished products is the source of a new civilization and a new power.

The New Empire of Business. The most powerful man in all ages has been he who could hold thousands and hundreds of thousands of men in one organization and successfully control their conduct. The best example of this kind of organization in ancient times was the army. Hence until the nineteenth century history practically ignores all rulers save those who could keep a nation in readiness to withstand an enemy and could lead successfully her armies against those of her hostile neighbors. Men seek power through the most popular channels. Since the invention of the steam engine, the steamboat, the locomotive, factory machines, the cotton gin, agricultural machines, and machines for the use of electricity, labor can be organized; and thousands of men are organized in a single business. To conduct such an organization 
a new ruler has appeared with more power over men than Alexander the Great or Napoleon Bonaparte ever had. The acquisition of so much power was impossible before the nineteenth century, because there was no way to unite the activities of so many people. Invention made the new régime possible, for by the use of machinery the labor of millions can be organized by one master mind. As a result we have an empire of business. For this new empire cotton opened the way.

So extensive is this new empire that it is not confined to the boundary lines of one nation, but it has drawn into its organization men from every country of the world. War is discredited because it endangers business, and military leaders are no longer the greatest men of the world.

It is in converting raw material into finished products that skilled labor is employed and developed. The organizations carrying on these industries make up the empire of business, and over these organizations we find the great captains of industry.

By 1880 the South had somewhat recuperated from the war, and the business centers were. shifting from the coastal plain to the Piedmont sections. In these sections skilled labor was first used and city building was begun. Before the development could proceed, railroads had to be built to connect the Piedmont section with the outside world, for large industries depend on other sections of the world for markets. 
The Variety of Manufacturing in the South. The South began her industrial development by manufacturing her natural products into coarse goods. In fact, the manufacturing was limited in the main to this kind of industry until the skill of her laborers could be more highly specialized. Fortunately, nature had placed within easy reach the greatest variety of natural products to be found in America.

Beginning with the forests of hardwood, which before the war had been barely toucherl, the industry of the South has caused the center of the lumber industry to be transferred from the Great Lakes to the Gulf Coast, and the principal markets for hardwood are now Memphis and New Orleans on the Gulf Coast and Newport News on the Atlantic. If we go from sawed lumber to a still more highly finished product we find that, while the center of this industry is still in the Northwest, at Grand Rapids, where the machinery is turned by water power, where transportation by rail and water is easy, and where the supply of skilled labor is greater than in the rest of America, High Point. North Carolina, is the center of a new furniture industry which is springing up all through the Piedmont South. Another use of hardwood is in making implements and vehicles. The leading area of this industry is in the states of Indiana, Illinois, Michigan, and Wisconsin, with Chicago as the center. In these localities, again, are to be found easy transportation and skilled labor. These 
forces always overcome geographic limitations. In the upland sections of Virginia, North Carolina, South Carolina, Georgia, Alabama, Tennessee, and Kentucky, where the hardwoods are abundant, transportation was slow in coming and skilled labor slow in developing. But since 1880 there has been a revolution in this section of the South, and furniture factories and vehicle factories have converted villages into towns, and towns into small cities.

The phosphate beds of South Carolina, Florida, and Tennessee, and the manufactured fertilizers of Charleston, the leather goods of Dallas, Waco, and San Antonio, the packing houses of Texas, the sugar refining of New Orleans,-each located in the locality where the raw material is produced,tell of the skill that is converting Southern products into finished goods.

The tobacco industry has contributed to the building of such towns and cities in the manufacturing sections of the South as Key West, Tampa, Louisville, Richmond, Petersburg, Durham, and Winston-Salem, whose products are sold throughout every civilized country and all are thus made to contribute to the wealth of the Southern States

Converting wheat into flour is another important industry in the Piedmont South, and Nashville, Knoxville, Chattanooga, Roanoke, and Fort Worth are supplying breadstuffs for hundreds of thousands of families beyond the cotton kingdom. In Alabama iron, coal, and limestone lie side by 
side, and Birmingham has become the center of the iron industry of the South, and her steel works,

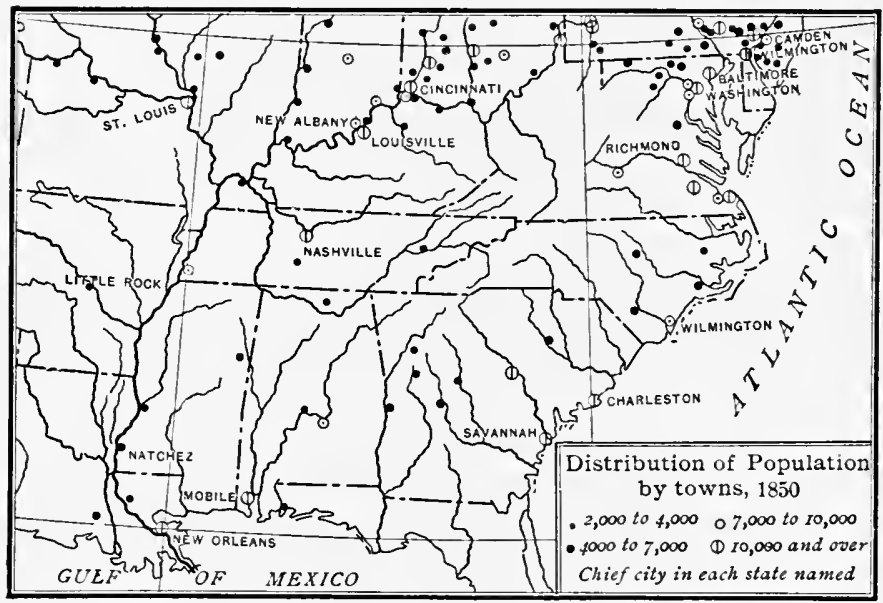

The leading trade centers in the South in 1850 . Compare with map on opposite page.

approaching those of Pittsburgh in importance. divide with those of that city the profits of the American iron industry.

The greatest change, however, has come in the manufacture of cotton goods and the by-products of the cotton plant. But these important industries are reserved for another chapter.

How Business moved to the Piedmont Sections. For more than two hundred years before the war the conter of population and power had been in the tidewater sections of the South, where cotton produc ion was the leading industry. The chief cities had been built on the coast or near the mouths of 
navigable streams, and the chief industries of these cities had to do with shipping cotton to foreign

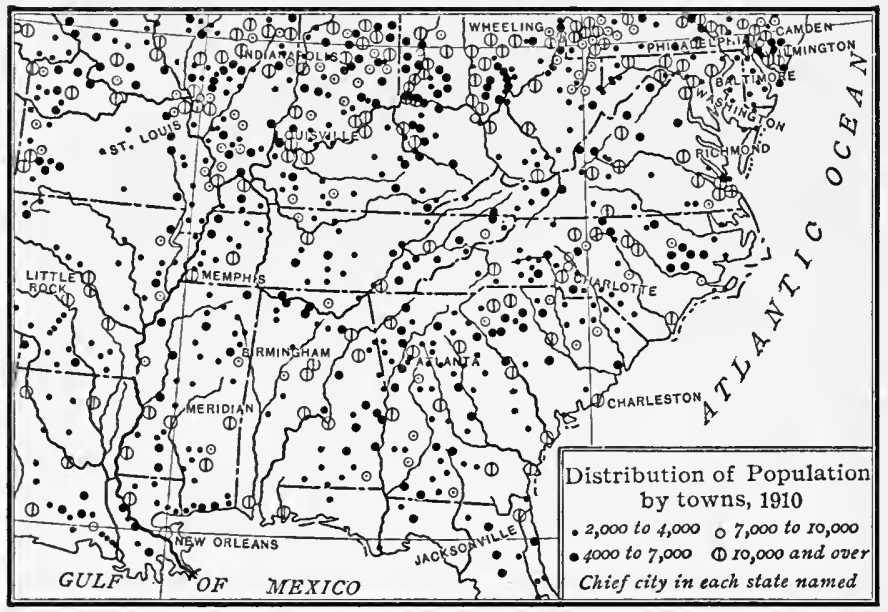

The leading trade centers in the South in I9ro, showing how business moved to the Piedmont.

countries. The wealth of the South, therefore, was derived from the activities of unskilled labor. We have seen in a former chapter that those countries that relied on skilled labor for converting this raw cotton imported from the South into finished products practically controlled the business of the South, for their agents were stationed in her chief ports, and furnished the money not only for the exportation of cotton but even for the production of it. A business carried on by machinery oper- ated by skilled labor is always more powerful than one carried on by unskilled men who work chiefly with their hands. 
This principle is clearly illustrated in the South. For when this development of transportation facilities made it possible for the Piedmont sections to reach the outside world, this upland, hilly country, that could not produce cotton, immediately went into manufacturing, and the centers of population and business have since moved westward to it. The census of IgIo shows that in North Carolina Charlotte is larger than Wilmington; in Georgia, Atlanta is larger than Savannah; and in Alabama, Birmingham is larger than Mobile.

Machine Labor vs. Ignorant Hand Labor. In our day the industry of the world centers in the steam or electric driven factory; for more and more mechanical power has been substituted for the human muscle, until at the present time the master workman is often only an intelligent onlooker, furnishing the machine with material and guiding its work. In this way one intelligent, skilled workman can do the work of a thousand slaves who ttse only their unskilled and clumsy hands.

This principle may be applied to agriculture. It is the tendency everywhere to eliminate unskilled hand labor. There is no more new land to be acquired, and the land now under cultivation must be made to feed and clothe an ever increasing number of people. Therefore skill, equal to that which has been applied to converting raw material into the finished products, must be applied to the cul- . tivation of the soil. The old crooked stick that was used for a plow in the days of Thomas Jefferson, 
and the old one-horse plow that was handled by a slave in the ante-bellum days, are disappearing; the modern roller gin, turning out hundreds of bales of cotton in a day, has displaced the old hand gin that was used before the days of Eli Whitney; the modern reaper has displaced the old hand scythe used in the days of Daniel Webster; the modern

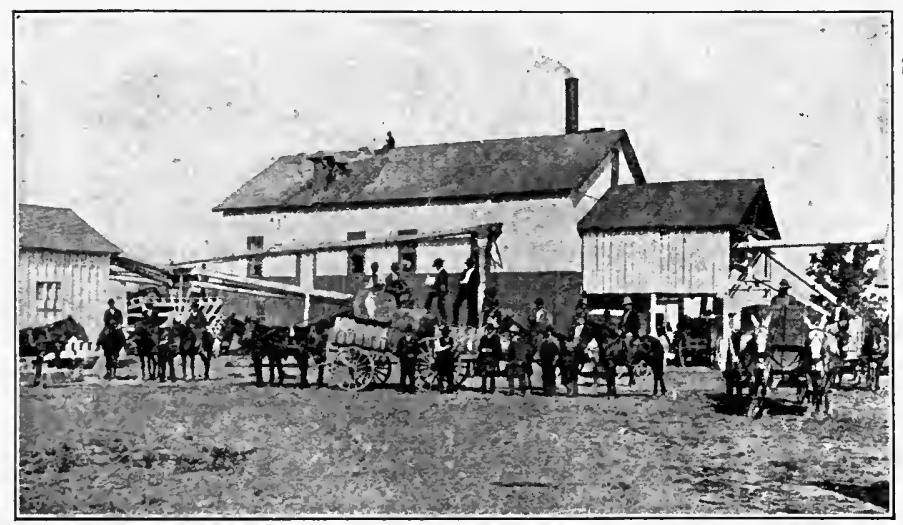

A cotton gin in an Arkansas town.

roller mills have displaced the old mortars used by our ante-revolutionary ancestors. In the cultivation of the soil new machines are gradually taking the place of the old ante-bellum hand tools in order that intelligent labor may be used in this industry as well as in the manufacture of the raw products of the soil. Ignorance is a curse, and nowhere is it a greater curse to-day than in the cultivation of land.

The Beginning of a New Plantation System. Since 1880 a great change has come over the South. 
The old plantations, already disintegrated, have passed into new hands. The owners no longer live in magnificent country homes and dispense hospitality as of old. These old homes are in ruins, but the land is again increasing in value. Improvements in farming utensils, gins, and presses, the development of good roads and railroads, the establishment of village banks, telephones, and rural free deliveries, an intelligent study of fertilizers, careful soil and plant study, seed selection, and agricultural colleges and experiment stations.these are some of the agencies that have come to the aid of the new planters, and a new plantation system is the result. 


\section{CHAPTER XII}

UNSKILLED LABOR GIVES WAY TO IMPROVED Machinery

Why Improved Tools and Machinery were not used before the War. An invention, or even an improvement in a tool or a machine, is usually the result of necessity. There must be a pressing need for it. Where there is slave labor or labor in abundance at little cost, there is little need for a machine which economizes or saves labor; and where hand labor can produce necessary results there is no need for machines to take its place. Hence there is little incentive to invention. In the case of separating the seed of the cotton from the lint, hand labor was inadequate before Eli Whitney's invention. An invention, therefore, was absolutely necessary. But in the cultivation of cotton there was sufficient slave labor, and no labor-saving improvements in the plow or other tools were especially needed. Therefore the plow in use in 1870 was little better than that used in 1820 . In the hands of unskilled labor nothing but the least complicated implements, such as could be easily made or repaired at the plantation blacksmith shop, could be used to advantage.

The Demand for Labor-saving Machines. After 
the close of the war there came radical social changes mentioned in a previous chapter. Negro labor became scarcer and less satisfactory. A demand arose for labor-saving devices to replace the hand labor which was now proving inefficient.

It has already been shown that many improvements in agricultural machinery were rapidly made, especially in the West, between 1850 and I860. During this period the value of agricultural machinery used in the United States increased from seven million to over twenty million dollars, though this increase affected the South but slightly. The plow was the first tool to be improved, and over twelve hundred patents for its improvement have been taken out. Commercial fertilizers were introduced about $\mathrm{I} 848$, and manufactured fertilizers about eight years later. About 1840 the McCormick reaper went to the aid of the Western farmer where wheat cultivation was the basis of wealth, and more than a thousand patents have been taken out for its improvement. From this time large plantations began to grow up in the West based on the use of machinery. With the improvements in the plow, the reaper, and many other agricultural implements the center of wealth traveled westward, but not southward. After the liberation of the slaves necessity called for improved tools and machinery in the cultivation of cotton, and they came-slowly at first; but they came. They had to come.

Evolution of the Plow. The first in order and 
importance of all agricultural operations is the breaking up of the soil, which is done by means of

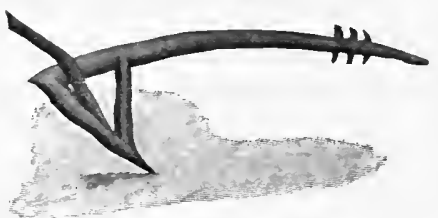

a. Ancient plow of Asia

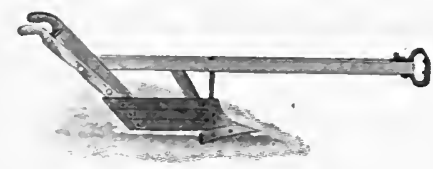

c. The first iron plow

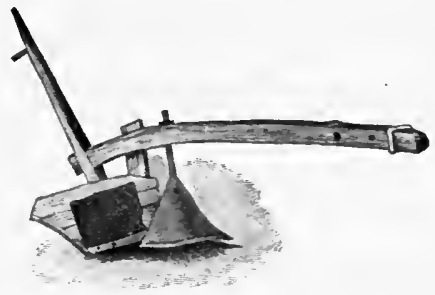

8. Colonial plow

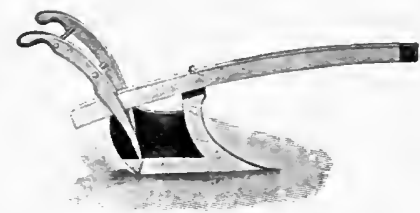

d. The first steel plow

Evolution of the plow.

a plow, one of the most ancient of implements. At first a plow was merely a kind of hoe worked by pressing the point into the ground. In earlier ages, when India was the only cotton country, the plow was little more than a crooked stick. The modern one-horse plow, however, with its mold boards for turning over the soil, was invented in The Netherlands a little more than two centuries ago. England and Scotland first took the lead in its improvement. In America, Thomas Jefferson, Jethro Wood, and others fashioned the one-horse plow that we are best acquainted with and which, with a few modifications, has been in use in the cotton. states from that day until the present time. Sixty per cent of 
a.1 the energy consumed in cultivating the land is spent in plowing, and the distance traveled by the plowman is enormous.

Food as well as clothing comes chiefly from the soil, and as population in America increased the old one-mule plow became totally inadequate, and necessity calied for improvements. As early as 1769 a patent was applied for in England which looked toward constructing a steam plow which would economize labor. However, the history of the steam p.ow does not begin until 1854 . From that date to the present time much interest has been shown in inventing and manufacturing machinery that will break up rapidly and thoroughly the great prairies of the IVest and the Southwest. Wholesale methods are the order of the day. Agriculture must develop enormously if it is to feed and clothe the people, and the farm hand must become a skilled laborer like the machinist in the factory. Invention is bringing these things to pass.

The world went from the crooked stick to the one-mule plow and from this to a two-mule plow. Here one laborer was dispensed with, but another mule was added. The two-mule plow changed again into a sulky plow, and the laborer rode. We have now come into the age of machinery. Mechanical labor is taking the place of human labor in almost all the processes of farm work. We sow our crops, tend them, and gather the products by machinery.. The grain drill, the cotton planter, the mower, the binder, the potato digger, the pea 
thrasher, the peanut picker, the hay loader, the hay press, the gang plow, the disk cultivator, the stalk cutter, a variety of harrows, and countless other machines do the tasks which our grandfathers used to do by hand.

No matter how perfect a machine is, unless there is sufficient power to run it good work cannot be done, and horse power is expensive. It was on the Western prairies that the question of power was first solved in America. We find there plantations embracing from forty to fifty thousand acres of land. These exceed in size anything that was known in the cotton kingdom in the days of slavery. While the farms in the South have been growing smaller and smaller, those in the West have been growing larger and larger. It was in the West, therefore, that the steam plow was developed in America, and the steam plow has tended to increase the size of the farms. Some of these traction engines have as much as a hundred and twenty horse power, draw behind them as many as fifty plows, and turn over from seventy-five to ninety acres a day.

From the steam engine we have gone to the gasoline engine. It is said that at least six hundred thousand of them are at present at work in America. Motors of many kinds are used in plowing, seeding, shredding fodder, loading and pressing hay, ginning, sawing wood, and even hauling cotton. The old-style farm wagon is being rapidly replaced, and motor power is being substituted. 
All these improvements came to the North and West and Southwest before they were introduced into the cotton kingdom. A new machine does not make its appearance until there is a demand for it, and this demand did not grow serious enough in the South until unskilled labor had proved unable to do the work. A machine is worked by skilled hands, and the time came in the cotton kingdom when new machinery was called for, and a premium was placed on skill.

To-day the cotton planter has developed a need for machinery, and those improved machines that

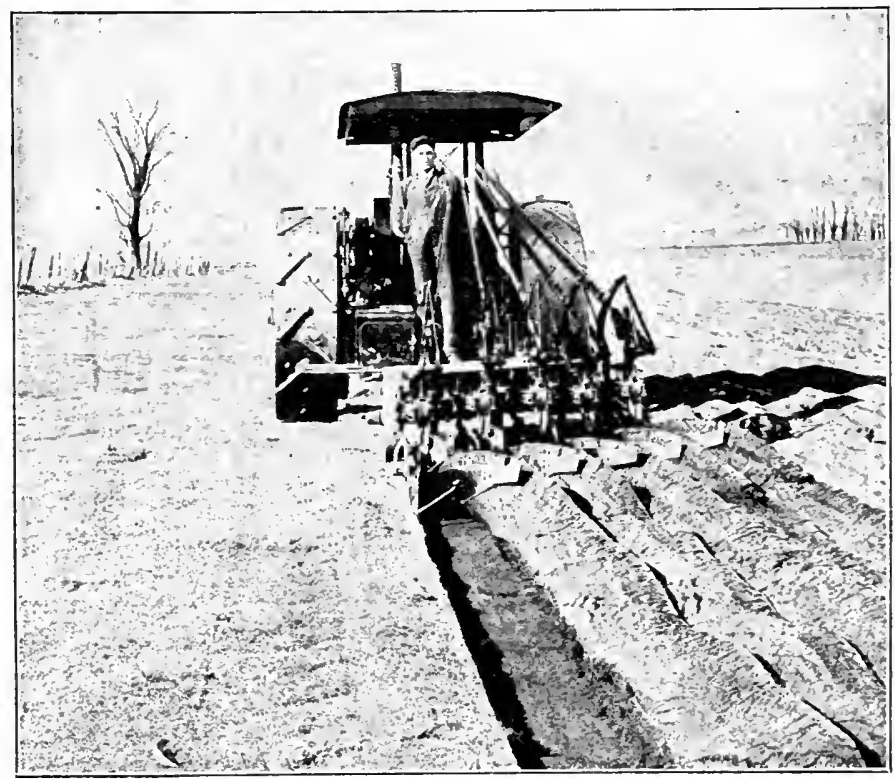

Courtesy of the International Harrester Co.

Plowing a ficld with a gasoline tractor. 
have been in use in the rest of the nation are coming into use in the cultivation of cotton, and unskilled

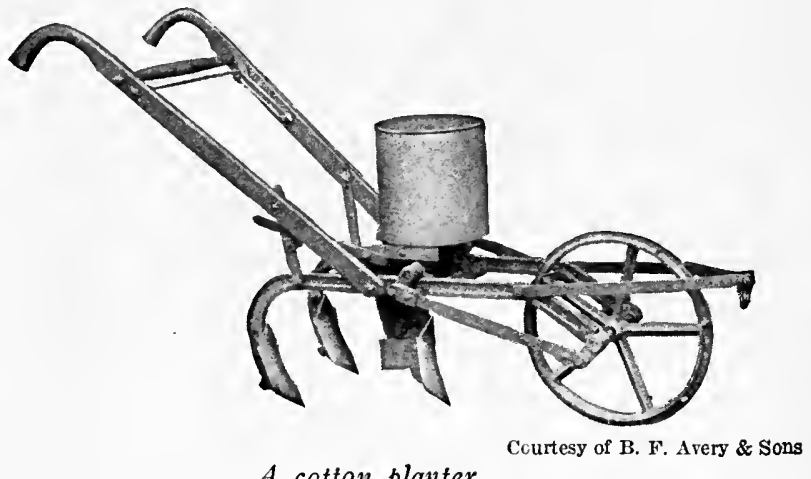

$A$ cotton planter.

labor is moving away. To turn an acre of ground with a one-horse plow requires about eight and a half miles of furrow travel; in plowing one square mile of land the plowman must walk over five thousand miles. Such methods of labor cried aloud for machinery, and it came.

The Cotton Planter. By referring to a previous chapter we learn how cotton was planted at the close of the Revolutionary War. Small hills were made, and the seed were deposited in them by hand. After the invention of the cotton gin this became too slow a process. The land was bedded, and one servant went along and with a hoe opened places at regular intervals into which a second hand, usually a boy, coming along later, dropped a few seed. Then followed a third boy with a hoe who covered the seed with earth. This work was usually done by women and children; and a good 
day's work for the three covered about one or two acres. In some sections of the South to-day both corn and cotton are planted in this manner.

After the war, however, labor became scarce and a new invention appeared known as the cotton planter. There are many varieties of the planter, but the principle is always the same. This new invention opens a furrow, and sows and covers the seed. Being drawn by a mule or horse, like a plow, one man now plants about eight acres a day, doing work that would have required ten or fifteen hands before the war. Again invention has freed the planter from the costly operation of ignorant and unskilled labor.

Improvements in the Gin. The old roller gin, or the churka that came from India, had been in use thousands of years before Eli Whitney's invention, which came at a time when the cotton states of the South were in sore distress for some machine that could relieve the hand labor necessary to separate the seed from the lint. The upland cotton, which is generally used in the cotton mills to-day and which has affected the welfare of more people than any other plant, is different from the cotton of India and Egypt, and different from the sea-island cotton. It clings tightly to the seed. A new invention was necessary to separate the seed from the lint, and Eli Whitney gave it to the world.

When the invention came, power had to be employed. By the aid of large wooden wheels, gears, 


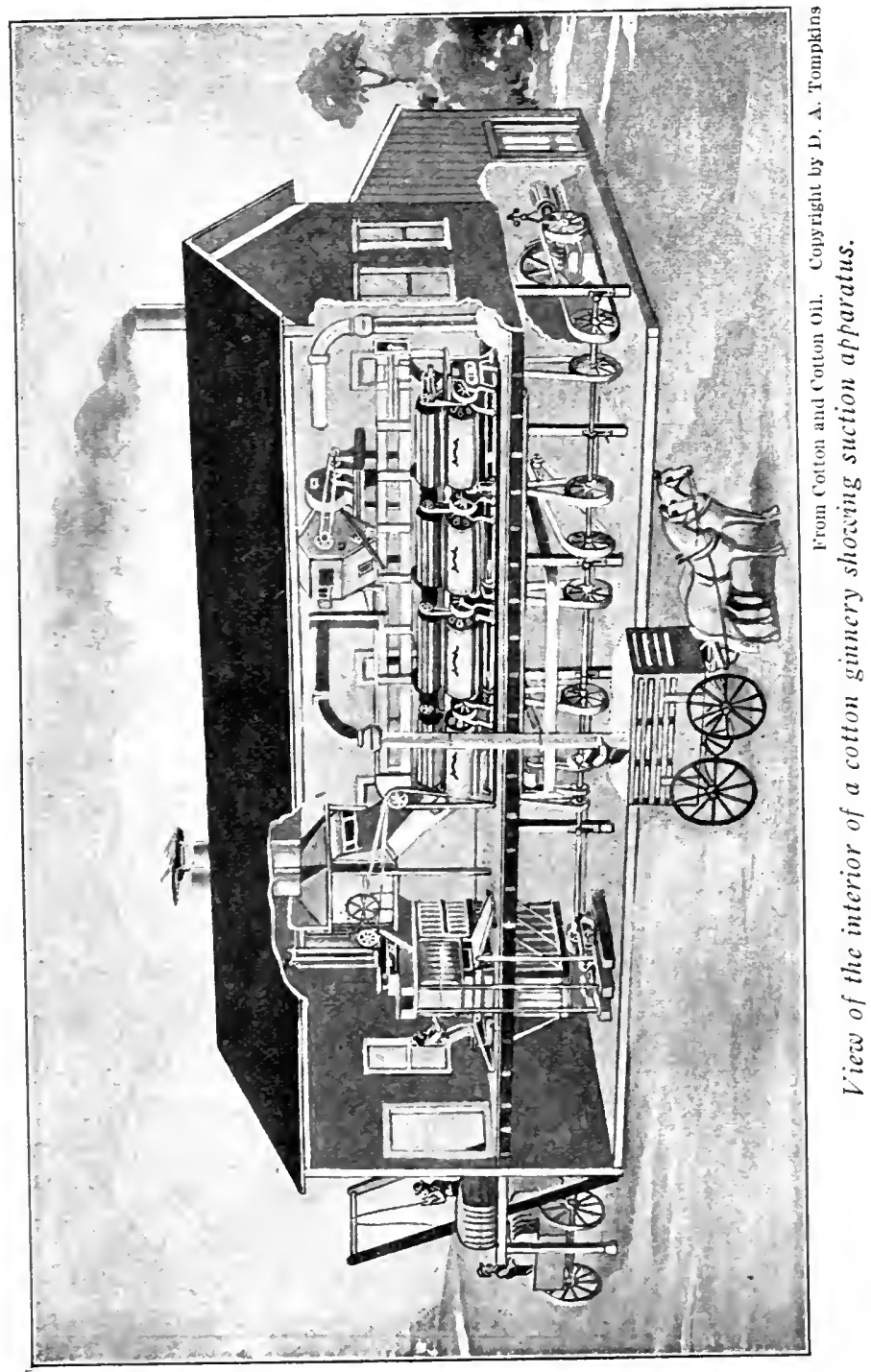


and levers, the mule was brought into use. Marked mechanical skill was shown in the use of this power, and its effect was to place the South ahead of all other cotton-producing countries of the world. A large gin house was constructed on posts, so that the mules or horses could operate this power underneath. Slave labor, which accorded well with mule power and wooden machinery, was sufficient, and this method of ginning cotton continued in use from about 1820 , when it came into general use, until about I870. Every large plantation had its gin louse and screw press, and all the labor, except separating the seed from the lint and pressing the cotton, was performed by hand. Cotton was picked by hand, carried into the gin house in baskets, fed to the gin by slaves, carried from the lint room to the press by slaves, packed by slaves, bound with ropes by slaves, and rolled away by slaves. The old cotton screw has been described elsewhere.

This was the method of preparing cotton for market when the war freed the slaves. By 1875 it was becoming very difficult to control negro labor as in the days of slavery. Hand labor was decreasing, and something had to be found to take its place. The need was supplied by the improved machinery.

Heretofore one hand stood at the gin and fed it with seed cotton; now an invention appeared in the nature of a mechanical feeder, and one hand was saved; and along with this came the condenser. 
In the days of slavery the lint room, while the gin was running, gave the appearance of a snowstorm, for the fine fiber was fanned into the room, which was filled with falling lint. The condenser which was now attached to the gin caught the lint and condensed it into bats or pressed layers of cotton. Immediately following this there came the compact press. The gin houses are no longer built on high posts. The steam engine furnishes the power. The press is placed in the old lint room and the cotton goes direct from the gin to the press, which is also operated by steam. Negroes are no longer needed to lift the cotton up the steps and carry it to the gin; by the use of suction pipes, operated by steam, the cotton is taken from the baskets, carried to the gin, and sent through to the press, where it is baled and rolled out for the market. With the aid of steam and many inventions the old wooden machinery, negro labor, and mule power have disappeared, and two or three men to-day do all the work that twenty or thirty slaves did seventy-five years ago. Thus invention has liberated man from the bondage and drudgery of muscular labor, and has also greatly reduced the cost of production. Today in the cotton kingdom the expense of ginning and baling is only about one fifth of what it was in 1870.

Modern Method of Baling Cotton. In the earliest gin houses a circular hole from two to three and one-half feet in diameter was cut through the upper floor. A large sack was suspended through 
it and here were packed the first "bags of cotton." "To-day old people still speak of bales as "bags" of

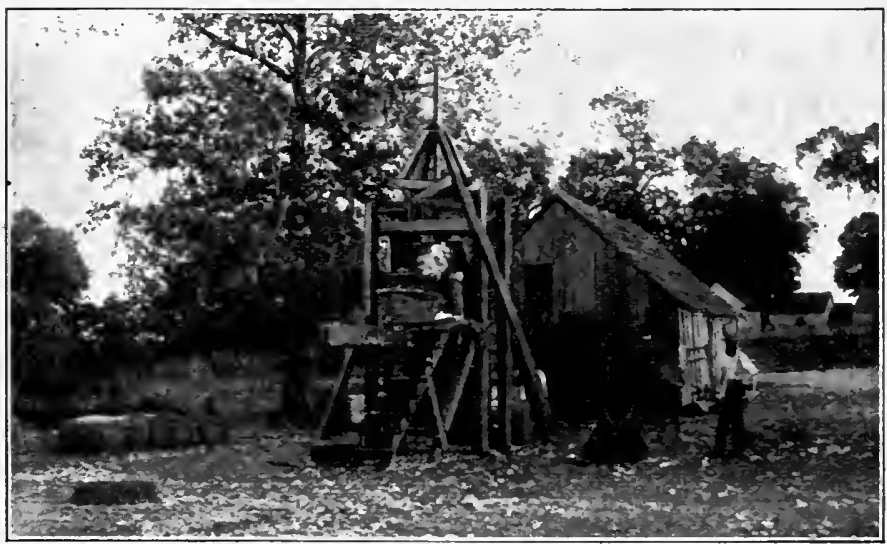

An old-time plantation cotton press.

cotton, which is a reminder of an ancient custom when cotton was really put into bags.

With an increase in production and a corresponding increase in commerce, it became necessary to press cotton into a tighter and more compact form. When packed lightly by hand it was too bulky and occupied too much space. In order, therefore, to get better results a box was constructed and men trampled the cotton down; but even this was not sufficient, and the screw press, which has been described elsewhere, was invented. The size of the bale now became fixed at from five to five and one-half feet long, about three feet thick, and five feet wide.

Unsettled and uncertain labor conditions made the old screw press too expensive, and the steam 
press took its place. In addition to the steam press of the plantation we now have the compress, because commerce needs even a more compact and a better covered bale than the old-style plantation

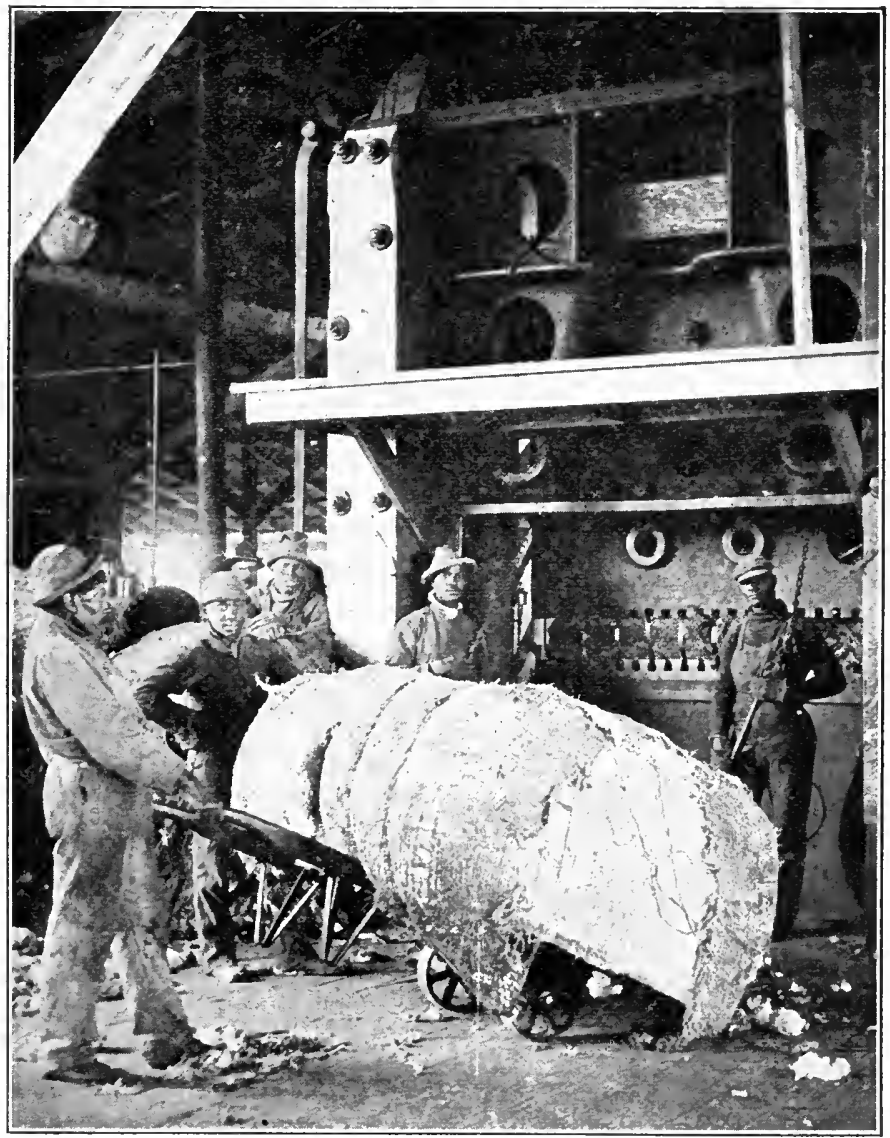

Courtesy of the International isarvester Co.

A modern compress. These presses will reduce a boo-pound bale from four feet to twelve inches in height. 
bale. In the days before the war there were few roads and no railroads in the South until about I845, and then only one or two lines in a state: therefore the baling of cotton had to be done with a view to convenience in transportation. After the war labor became scarce and necessity forced the planters to. use mechanical contrivances. The steam engine was introduced, then the steam railway. Thus one improvement always calls for another, and the world keeps advancing.

Better Transportation Facilities. The marketing season is in the fall of the year. Owing to poor roads, lack of railroads, and the large amount of cotton to sell, the planter before the war sold his cotton through commission merchants. These merchants usually charged a commission for furnishing the money to produce the crop, then a commission for hauling the crop, in addition to charges for insurance and storage. These commission merchants in many instances bought the supplies for the large planter and handled his crop. After the war this method was revived, and caused the ruin of many plantations where the planter was unable to control the labor.

When the plantations began to break up, as has been described in a former chapter, small farms took their place, and local village and town merchants took the place of the old commission merchant. This change was made possible by the development of railroads in the South, and railroad building has increased wonderfully since I880. In 
that year the total mileage in all the Southern States was only about twenty thousand miles, but

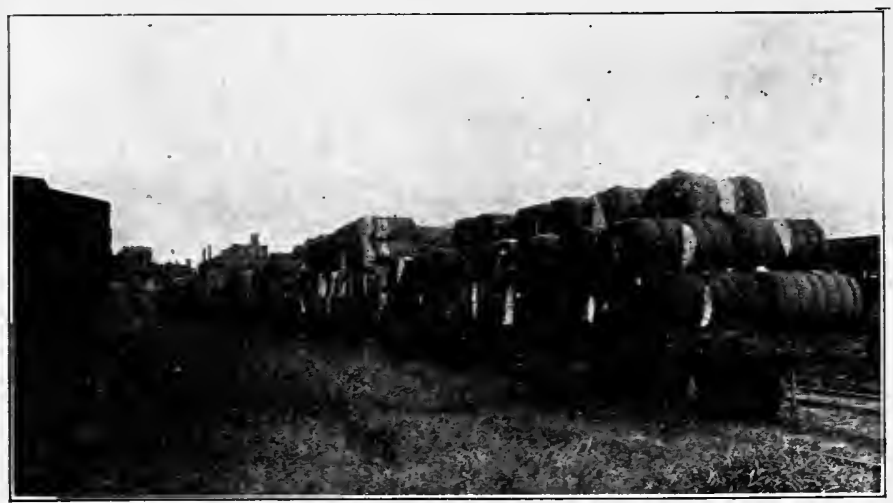

Courtesy of A. Clogenson, Dallas, Tex. A trainload of cotton on its way to the factories.

in I9Io this had increased to about seventy-two thousand miles, or more than three and one-half times as much.

If we compare this with the increase in the whole of America we find that in the nation the mileage has increased from ninety-two thousand six hundred miles to two hundred forty-two thousand miles, or not quite two and one-half times, while in the South the increase has been three and one-half fold. Railroad building has been a great factor in the development of cotton production and cotton manufacturing. The wealth of a country to-day depends upon the ease with which the inhabitants of that country can market its natural or manufactured products; and most farms are within a reasonable distance of railroad stations or steam- 
boat landings. A local merchant class, therefore, has developed in the South, while the old commission merchant and his large and ruinous profits have disappeared.

Good Roads. When the original settlers found a home in the South, as a rule they located on the

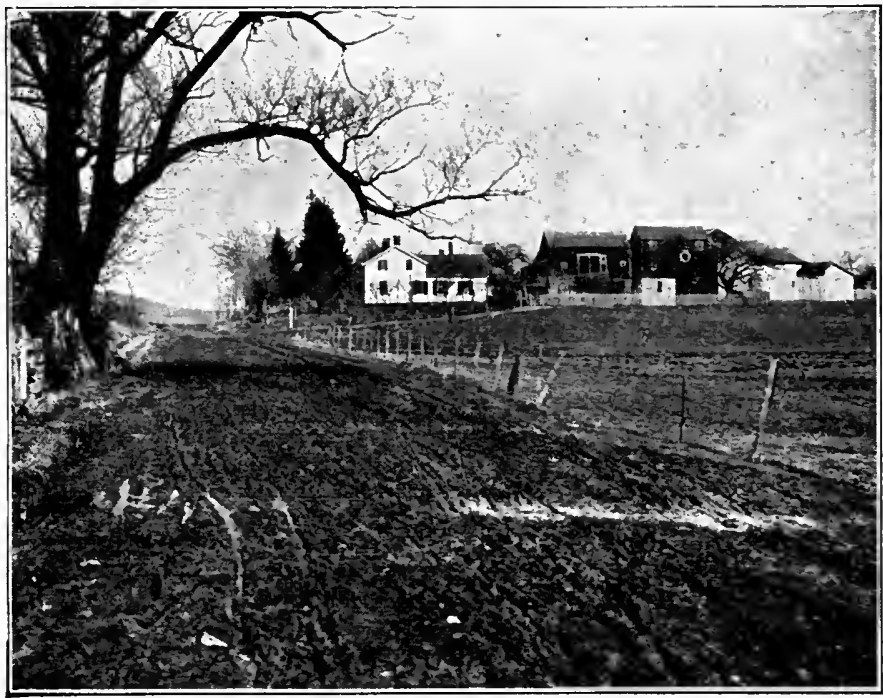

From Commercial Geography by E. V. Robinson

The old-time mud road.

river banks and used the streams for highways. Even their houses faced the rivers. When they traveled overland they usually went by the compass or the heavens, and traveled through a primeval forest that was unbroken by any road. The Indian trail was the only thing that resembled a road. As settlements increased the people were content 
simply to open a way through the forest at a very small cost, and soon most inhabitable places were supplied with roads of some sort. This old-time roal served its purpose as well as mule power, ncgro labor, and wooden machinery, when the farm produced everything it needed and shipped cotton

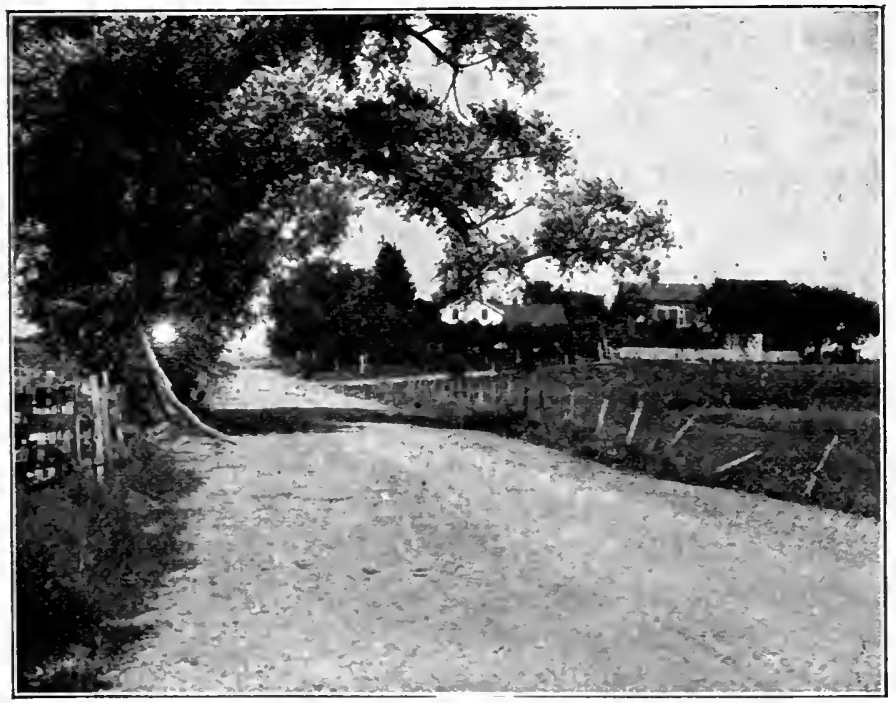

From Commercial Geography by E. V. Robinson

The same road improved.

only. But it ceased to be adequate years ago when the planters began to rely on the merchant for many of his supplies. To-day the planter hauls his cotton to market and brings back his fertilizers; to-day he takes his truck and poultry to market and brings back his clothing. He has improved his vehicles, but only lately has he begun to improve 
the roads, which are his chief avenues for exchanging goods. To-day the old forest road, washed out and cut up so that it is next to impassable in bad weather, stands as a barrier to the progress of the people of the South. However, it, too, is slowly giving place to well-built roads.

The growth of towns and cities and the development of railroads and manufacturing create a population dependent entirely upon the labors of others for their food, since they are without the opportunity of raising these necessary things around their own homes. The people who live thus must draw on the farmer for the necessities of life. The value of farm products, therefore, is determined in a large measure by the convenience with which they can be marketed. For instance, in I909, when eggs were selling at thirty-five cents a dozen in one county in North Carolina they were selling for twelve and a half cents a dozen in another county of the same state. Large manufacturing towns must have food, and it must come from the country. The farmer who can reach the town with little cost receives a high price at home, while the farmer who has poor transportation facilities must lose the greater part of the value of his products in the cost of transportation and marketing. The first county mentioned above is located in the section of the state where there are good transportation facilities, including both railroads and country roads. The latter have been developed extensively and connect every part of the county 
with a large manufacturing town. The other county is located in a section where there are no railroads and where the country roads are impassable for several months in the year. In this county the people can neither import nor export to advantage, and since they are unable to connect with the great world of activity beyond them, they must live in a measure as our ancestors lived a hundred years ago.

In the days of slavery there were few large towns away from the seacoast. The towns which existed depended upon the commerce of the interior with Northern states and foreign countries. They handled the raw products of the plantation as they went out to the world and handled in return the manufactured products as they returned to the plantations.

The growth of towns and cities in the Piedmont South has taken much of the commerce from the seaport towns, for these cities are doing for the agricultural sections what the foreign cities did before the war. Then railroads and water routes were needed to reach foreign cities. Now good roads, well constructed, are needed everywhere to connect the cities with the plantations and the industry of the farmer with the commerce of the world.

It has become therefore an established principle to tax the whole county, cities and rural sections alike, in order that an exchange of products may easily be effected with the least expense. A whole county to-day issues bonds for from a hundred to 
five hundred thousand dollars; road specialists are employed, and roads are constructed of crushed

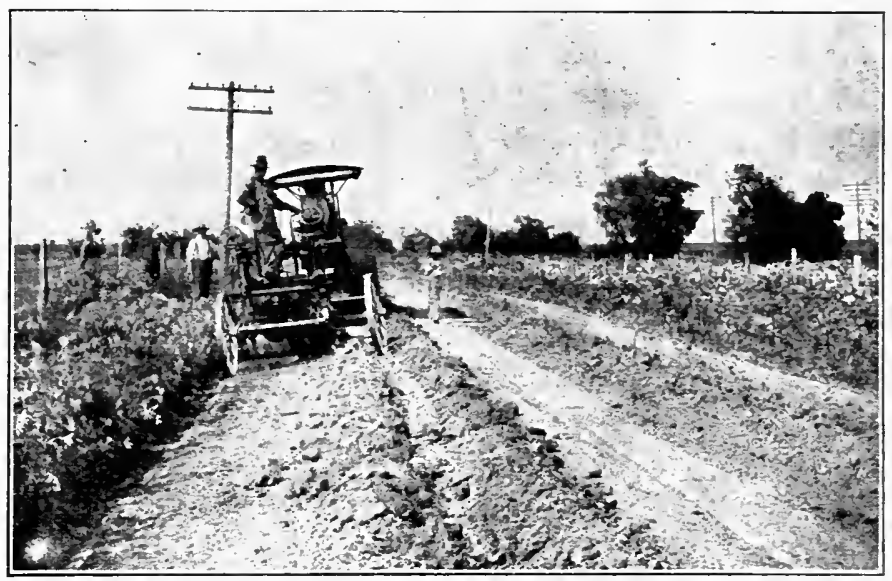

Courtesy of A. Clogenson, Dallas, Tex.

A road-making machine at work.

rock to a depth of five, six, or eight inches, or of a mixture of sand and clay to a depth of eight or ten inches. Thus we have come from the old Indian trail to the old forest road, and from the latter to a hard, smooth, and well-drained road capable of bearing a one-horse load ten times as great as those carried in the days of slavery.

Another Invention is needed. The improved plows, harrows, and cultivators have come to take the place of the slave. The improved gin and presses have taken the occupation from the mule and the slave. Good roads and the building of railroads have displaced the old wagon driver and his team of six mules winding slowly over old forest 
roads. But in the picking of cotton, men, women, and children, both white and black, are employed exactly as they were in the days before the invention of the cotton gin, or when each plantation had slaves in abundance. In all the labor disturbances since the war and in all the economic changes, the method of picking cotton has been unchanged, and to-day the entire cotton crop of thirteen million bales must be picked by hand. Pickers usually carry a sack strapped over their shoulders, and as they walk or crawl along the rows the cotton is picked from the stalk by hand and dropped into this sack. Hand labor is expensive, and the cost of picking ranges from forty cents to one dollar a hundred pounds; and if labor is scarce the crop is damaged.

This method of picking cotton limits the quantity produced. Cotton picking at seventy-five cents a hundred-the price paid in certain localities-is a cost of two and one-half cents per pound of lint cotton, ${ }^{1}$ and with cotton selling at ten cents a pound this is one fourth of the price of the cotton. The farmer now needs more hand labor for picking cotton than for its cultivation. This was not the case in the days of slavery, when nearly all work was done by hand. Therefore, now, in the fall of the year, an extra number of laborers must be

1 One hundred pounds of seed cotton will make when ginned about thirty-three and one-third pounds of lint. Farmers usually send, therefore, about one thousand five hundred pounds of seed cotton to the gin and they expect to secure a five-hundred-pound bale of cotton. 
secured or the cotton is damaged or lost. Invention has come to the aid of the cultivation and the ginning, but has not helped the picking. The old equation has been disturbed; and the cotton states are now laboring with this question: How can labor be so controlled that it can be dispensed with during the whole year except the months of Sepber, October, November, and December?

Many negroes have flocked to the towns. Here they lead a precarious existence until in the fall of the year, when they flock back to the cotton fields, where they receive good wages for a few months. This migration disturbs the labor situation in the towns, since all domestic duties have to be adjusted to the exodus that begins to take place about the first of September. Men, women, and children go from the mill, the kitchen, the stable, the school, and everywhere. Normal vocations are disturbed until the cotton has been picked.

Necessity is now demanding another invention, for in the production of cotton the world has come around to a state similar to that when the invention of the spinning frame and power loom demanded a cotton gin that would supply the factories with lint cotton. The inventions that have come to the aid of the planter in cultivating cotton have reached the limit of their usefulness until another invention can be perfected that will harvest the crop and complete the process. This invention is already making its appearance.

The Cotton Picker. The cotton kingdom needs 
a machine that will pick cotton; then the whole process of cultivation will pass out of the hands of unskilled labor and will be on a plane with manufacturing. This machine is now in the process of making. During the past twenty years numerous patents have been issued. A Mr. Mason of South Carolina, a quarter of a century ago, came near getting a machine that would work, and others - have likewise approached a solution of the problem.

About twenty-five years ago Mr. Angus Campbell, an inventor of Chicago, made a pleasure trip to Texas, where he saw hundreds of men, women, and children dragging sacks step by step through the cotton fields as they picked the cotton from the open bolls. From that year until the present time he has been at work on a machine that would do the work of hundreds of hands. His first machine was pulled by a mule, but a mule in a field of ripe cotton is too destructive. Then came the traction engine and the gasoline engine, and the mule was no longer needed.

After experimenting about a quarter of a century, Mr. Campbell finally made a machine consisting of two upright cylinders arranged to pass on opposite sides of the row and poke their steel fingers in from the sides. These steel fingers contain slightly indented teeth constructed so that they hold the fiber as soon as they touch it. This machine has been tried with success. It now consists of a small gasoline traction engine with two picking attachments swung under it and a pair of 
canvas bags hung on behind to catch the cotton, and it travels through the field about as fast as a man walks, taking the cotton plants between the wheels. There are over eight hundred spindles or steel fingers that enter the branches of the plant and pick the cotton by winding the fiber around each spindle as it revolves rapidly. While the machine moves forward the spindles move backward, carrying the fiber to the canvas bags in the rear. The machine requires one man to sit in front to guide it and a boy to sit behind to push the cotton into the bags. The machine itself does the rest, and can cover eight or ten acres and pick about six thousand pounds of cotton a day.

The machine is so constructed that the picking part can be removed and other farm implements attached, such as the subsoil plow, the disk harrow, and the cultivator. In this way the gasoline engine will form the motive power for the entire cultivation of cotton, and the last act of unskilled labor on the farm will be removed.

This machine has been tried only in a limited way. Its endurance must be determined by working it day after day. There will probably be many improvements made before it will be a complete success, but the principle has been discovered. On the day when two machines were to give an exhibition in Texas, farmers from miles around came on horseback, in buggies, in wagons, and in automobiles, flocking to see the machine pick cotton. The cotton field was gray for hundreds of yards with 
the dust that had been stirred by the moving crowd, and when the machine started down the rows and

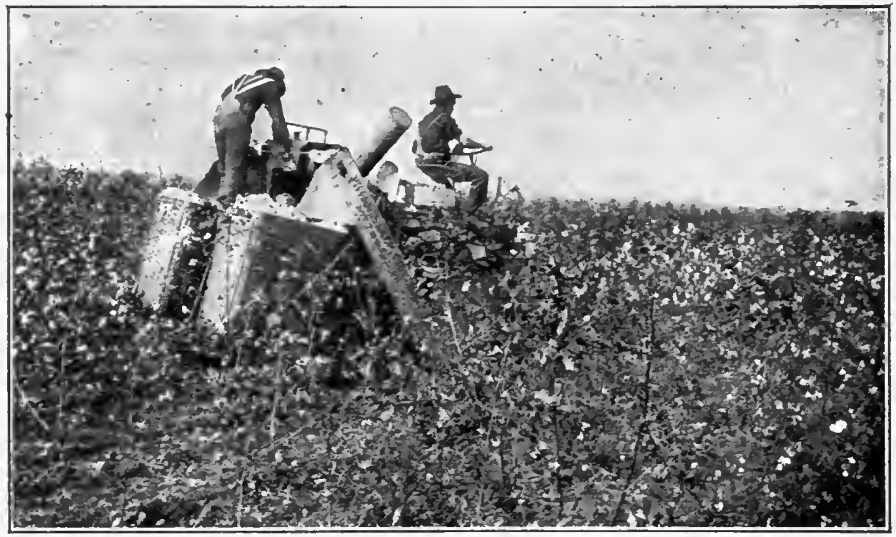

Copyright, 1906, by H. Clogenson, Dallas, Tex.

The cotton-picking machine at work. It is run by gasoline, and in an ordinary field will pick 250 pounds in twenty-five minutes.

the cotton began to drop into the bags behind, the crowd spread itself all over the field, in front, behind, and all around the picker. It worked.

Such a machine will eliminate the drudgery of farm life, and to some extent banish the ignorant negro and the mule from the plantation. It will liberate the children from the cotton field and give them an opportunity to go to school and acquire more skill; it will end the labor disturbances of the villages and cities in the fall of the year; it will place in the hands of the planters a force that will make them more powerful than were the landlords in the days of slavery; it will practically end the vasteful tenant system that has been increasing 
rapidly since $\mathrm{I} 880$; and finally, it will create a new country life attraction because of the skill required and the physical drudgery eliminated. Because of this new power acquired, cotton will again to some extent become king; and the South will be the kingdom of the king, whose subjects will this time be free. 


\section{CHAPTER XIII}

Cotton Manufacturing

Invention and the Arts of Life. It has been said that the unfolding of the arts of life runs parallel with the history of inventions and discoveries. The latter half of the eighteenth and the whole of the nineteenth centuries probably gave more great inventions to the world than all the previous centuries combined, and certainly during this century and a half the arts of life unfolded more rapidly than during any similar period in the world's history.

We have only to compare the social and economic life of to-day with that of a hundred years ago to see that vast changes have taken place, and one of the chief agencies in bringing about these changes was the development of the factory industries through the great inventions of the latter half of the eighteenth century. The greatest of these industries was cotton manufacturing, which was developed first in England, then in the rest of the world. There are several reasons why the cotton factory was first developed in England and why, after cotton weaving was once established, that country continued to be the great center of the world's manufacturing. 


\section{Why England became the Center of Cotton} Manufacturing. During the eighteenth century England experienced three great economic revolutions and the consolidation of small farms into large estates led to a much better system of farning, through the application of sufficient capital to that industry. At that time wool was king of clothing, and the demand for that fiber led the new class of capitalistic farmers to adopt a more intensive system of agriculture, with a view to growing grasses, grain, and stock food. In that century also England laid the foundations of her great commercial supremacy.

After the American and the French revolutions England was mistress of the sea, and her merchantmen opened markets in practically every civilized port of the globe. The growth of this commerce stimulated the industries at home. Manufacturing, mining, agriculture, trade, and commerce were creating a new division of labor. As a result those engaged in producing food and clothing for the whole number had to have greater and greater skill, since fewer people, in proportion to the whole number, had to produce a larger quantity and a finer quality of goods. In order to meet the requirements of these new conditions, if the unfolding of the arts of life was to go on, it was now necessary that the laborers have the aid of mechanical agencies. Therefore the unfolding of the arts of life took place more rapidly in England because the great mechanical skill found in that 
country produced the inventions which were necessary to meet the demands of the laborers.

When the making of clothing was taken from the home and carried to the factory wool was the chief material used for clothing, and the first of these inventions was designed for use in the manufacture of wool. But in 1793 Whitney invented the cotton gin, which made it possible for the factories employing these machines to use cotton instead of wool, and, consequently, the South began to supply the fiber for the factories of the world. The South developed along the line of least resistance, and, while she was bending her energies to the production of cotton, England was perfecting her factories and increasing the skill of her labor, with a view of converting this raw material into finished products. Having thus made herself ready when domestic hand work passed over into the organized factory, England was better prepared than any other country in the world to adopt and reap the benefits of this new form of industrial organization. Therefore she became the center of cotton manufacture and was able to import cotton from a country three thousand miles away, convert it into finished products, send it back three thousand miles, and dispose of it at great profit, all because of these inventions and the superior skill of her laborers.

How the Factory was developed. It was about I 835 that the transfer of the domestic handwork to the factory was completed, and the following 
table ${ }^{1}$ shows clearly where the greatest inventions were perfected, all except the cotton gin being the work of Englishmen.

\begin{tabular}{|c|c|c|c|}
\hline \multicolumn{4}{|c|}{ COTTON IMPORTED } \\
\hline Date & LBS. & Date & INVENTIONS \\
\hline \multirow[t]{2}{*}{ I730 } & $1,545,472$ & 1730 & Watt's roller spinning. \\
\hline & & 1738 & Kay's fly shuttle. \\
\hline I74I & $\mathrm{I}, 645,03 \mathrm{I}$ & 1748 & Paul's carding machine. \\
\hline \multirow[t]{3}{*}{1764} & $3,870,392$ & 1764 & Hargreave's spinning jenny. \\
\hline & & 1764 & Calico printing introduced. \\
\hline & & 1768 & Arkwright perfects spinning frame. \\
\hline \multicolumn{4}{|c|}{1771 ) } \\
\hline to & $4,764,589$ & $177 \mathrm{I}$ & Arkwright's mill built. \\
\hline \multicolumn{4}{|l|}{ I775 } \\
\hline & & I775 & $\begin{array}{l}\text { Arkw right's patent for carding, rov- } \\
\text { ing, spinning. }\end{array}$ \\
\hline & & 1779 & Crompton's "Mule" completed. \\
\hline I781 & $5,189,775$ & & \\
\hline 1785 & $18,400,384$ & 1785 & Cartwright's power loom. \\
\hline & & & $\begin{array}{l}\text { Watt and Bolton's first engine for } \\
\text { cotton mills. }\end{array}$ \\
\hline 1793 & $34,907,497$ & I793 & Whitney's saw gin. \\
\hline I8I3 & $51,000,000$ & I8I 3 & Horrock's dressing machine. \\
\hline 1830 & $261,200,000$ & I830 & "Throstle" for spinning warp. \\
\hline 1832 & $287,000,000$ & 1832 & Roberts' self-acting mule. \\
\hline $184 \mathrm{I}$ & $489,900,000$ & I84I & Bulloughs' improved power loom. \\
\hline
\end{tabular}

The inventions mentioned in the table which were perfected between I730 and I793 were designed for use in the manufacture of wool. The cotton used was mixed with wool and came chiefly from the West Indies, Egypt, Mexico, Brazil, and India. In I793 the Whitney gin, the only invention of American origin, made it possible for cotton to be used instead of wool, and the enormous increase

${ }^{1}$ From H. W. Thurston's Economic and Industrial History, p. 139 . 
in the amount of cotton sent to England as a result may be seen from this table. In 1840 the Soutl produced I,347,640 bales, and I,060,408 bales of this were consumed in the mills of England. In that country the arts of life were more highly developed than elsewhere. Therefore all the leading inventions which applied to the cotton factory were productions of English mechanics. America at first merely copied and reproduced these machines, and the history of cotton manufacturing until the last half of the nineteenth century largely has to do with England. During that early period it was the Englishman's brain that was instructing the world in the arts of cotton manufacturing, and it was to. England that the American went to learn how to manufacture the fiber raised at his own door.

How the Factory developed in America. Every people, in converting the raw material into the finished products, first produces the coarser goods. This is natural, for the quality of the product becomes better as the skill of the laborers increases and machines are employed. Since all the early improvements in the machines for manufacturing cotton were made in England, that country had a world-wide reputation when America was clumsily making the coarser goods. WVe have told in a previous chapter how England guarded her machines. She did this so successfully that, although the new inventions found their way into America after many hindrances, the skill of the Englishman was 
so far superior to the skill of the American that it was only by the aid of a high protective tariff that the American factory was able at first to exist.

We have already told how Samuel Slater, a skilled workman in Arkwright's mill, came to America and reproduced the machine in this country, and how Francis C. Lowell studied in England and, returning to America, established in I8I4 the first complete factory in America. We have seen also how the South turned more and more to producing cotton and less and less to manufacturing cotton goods, and how the politics of the country from 1816 to 1832 were concerned largely with encouraging cotton manufacturing in America. The English operatives had a dexterity acquired by long practice, and the American mills, developing more slowly, were unable to compete with the English mills, where skill was so much more highly developed.

A table (p. 209) in the previous chapter shows what a small amount of the cotton produced in the South was manufactured in America. But New England and the north were rapidly learning the art of manufacturing cotton goods, and every nation of Europe was doing likewise; they had the dexterity acquired by long experience sooner than the Southern States.

The Beginnings of Cotton Manufacture in the South. We have referred in a previous chapter to the fact that about the year 1840 the South made an effort to manufacture cotton. In that year the 
South consumed only 7 I,00o bales, the greater part of which was converted into the coarser fabrics by the aid of the old hand loom and the spinning wheel. In that same year the New England States consumed about I60,000 bales, while Europe consumed I, I00,000 bales, and in I860 the cotton states consumed only 93,500 bales; while the rest of America used 750,000 bales and Europe, 3,535,000 bales.

It will be observed from these figures that the skill and enterprise of American workmen, and especially those of the Southern States, by no means equaled that of the Europeans in cotton manufacturing. The great improvements in machinery were to be found in England, and in that country skill and inventive genius were able to overcome geographical limitations and levy tribute even on the cotton kingdom. But a new era started in the South about I880, fifteen years after the negroes were freed. Since about 189,000 bales of cotton were consumed in that year it was evident that the South was beginning to build cotton factories. The old spinning wheel and hand loom had at last begun to give place to skilled labor using improved machinery. The rest of America in that year consumed I,380,000 bales of cotton, while Europe consumed 3,645,000 bales. England therefore had gained little over 1860 in the quantity consumed, judging from the exports from America, while in the United States the consumption had almost doubled, the chief gain, however, being outside the 
cotton kingdom. But the next twenty years tell an entirely different tale. The whole civilization of the South had been overturned, a new spirit had entered the educational system, a new idea in regard to the value of skilled labor and personal worth was taking the place of the old notions held during the days of the slavery régime and landed aristocracy, and we have the beginning of the factory system in the South.

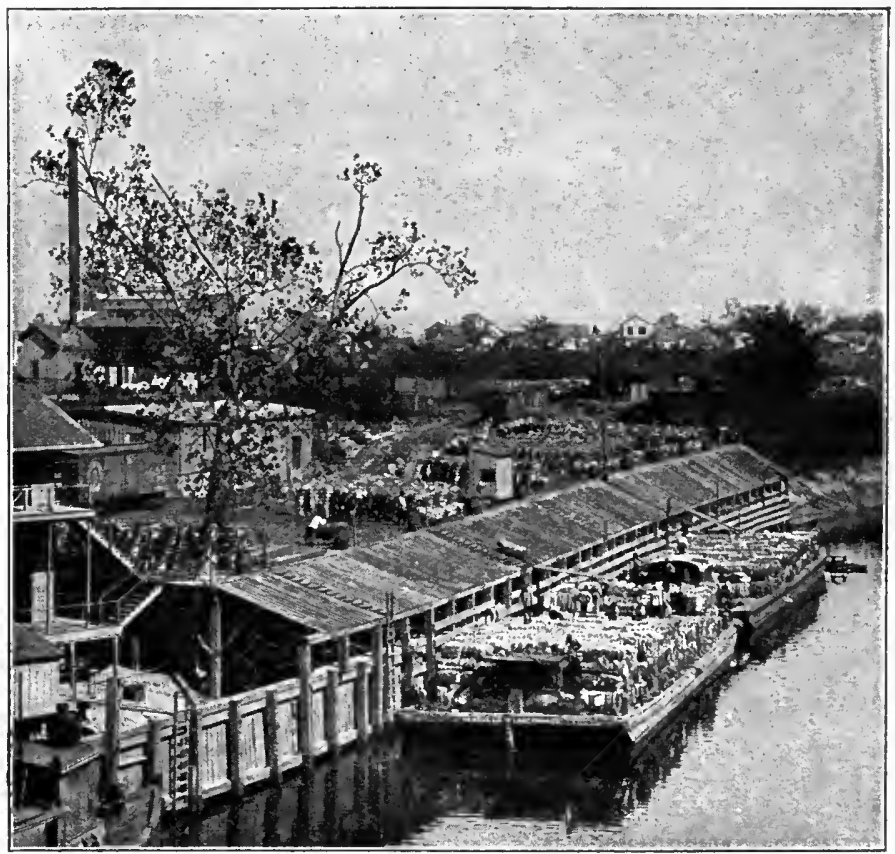

Copyright by Underwood \& Underwood, N. Y.

$A$ river scene. Here cotton from near-by fields, bound for the factories, is being loaded on river barges. 
The following table tells the story of the growth of cotton factories in the three leading cottonmanufacturing states of the South since r 840 :

\section{North Carolina}

No. No.

YEAR Factories

I $840 \ldots 25$

I $860 \ldots 39$

I $880 \ldots 49$

$1900 \ldots 177$

I910 ....331

41,884

92,385

$\mathrm{I}, \mathrm{I} 33,432$

$3,374,917$
South Carolina

No.

15

17
Carolina

Spindles

16,355

30,890

82,334

I,43I, 349

$4,064,320$

Georgia

\begin{tabular}{cr}
$\begin{array}{c}\text { No. } \\
\text { Factories }\end{array}$ & \multicolumn{1}{c}{$\begin{array}{c}\text { No. } \\
\text { Spindles }\end{array}$} \\
19 & 42,589 \\
33 & 85,186 \\
40 & 198,656 \\
68 & 817,345 \\
I57 & $1,972,833$
\end{tabular}

The Development of the Factory in the South. It is apparent from this table that the real factory life in the South dates from I880, for since that time there have been rapid developments. Great accumulation of capital and a redistribution of labor have been the result. Towns and cities have been built, and the whole social life has experienced a complete transformation. But dexterity in converting raw material into finished products comes after long experience, and the Southern cotton states entered the manufacturing world behind the rest of the nation. The cotton states however have one advantage-their close proximity to the cotton fields-and the increase in cotton manufacturing from 1880 to I9Io shows how valuable is this advantage. Yet in manufacturing the finer goods this advantage does not overbalance the skill and dexterity which the rest of the world has acquired as a result of long experience, for the Southern states are still, as a rule, manufacturing the coarser and the cheaper goods. 
In 1900 the South consumed I,523,000 bales while the rest of America consumed 2,350,000 bales. But the annual consumption of all Europe by this time had jumped to $6,167,000$ bales. Nine years later, that is, in 1909, the South used 2,554,000 bales and the remainder of America only 2,686,000 bales, while Europe used 8,890,000 bales.

So great has been the development of cotton manufacturing in the Piedmont sections of the South, especially in North Carolina, South Carolina, and Georgia, that a traveler going to-day by rail from Danville, Virginia, to Atlanta, Georgia, would during the whole journey hardly be out of sight of the smoke rising from some cotton factory. The mills of the South consume to-day almost as many bales as the rest of America, and less than one fourth as much as the whole of Europe; in I880 the South consumed only about one seventh as much as the remainder of America and only about one twentieth as much as the whole of Europe. This industry is building a new South in the Piedmont sections of the cotton kingdom. Thirty years ago there were only about 16,000 employees engaged in the cotton mills of the South. To-day there are about 225,000 . Then there were only 561,360 spindles operated; to-day there are Io,80I,494. In some counties of the South one third the population receives its support from cotton factories. Nothing indicates the industrial change so muich as the fact that many states of the cotton ki..gdom support by public taxation schools for 
teaching the textile arts. Verily, this is not the old South, where labor was performed by unskilled

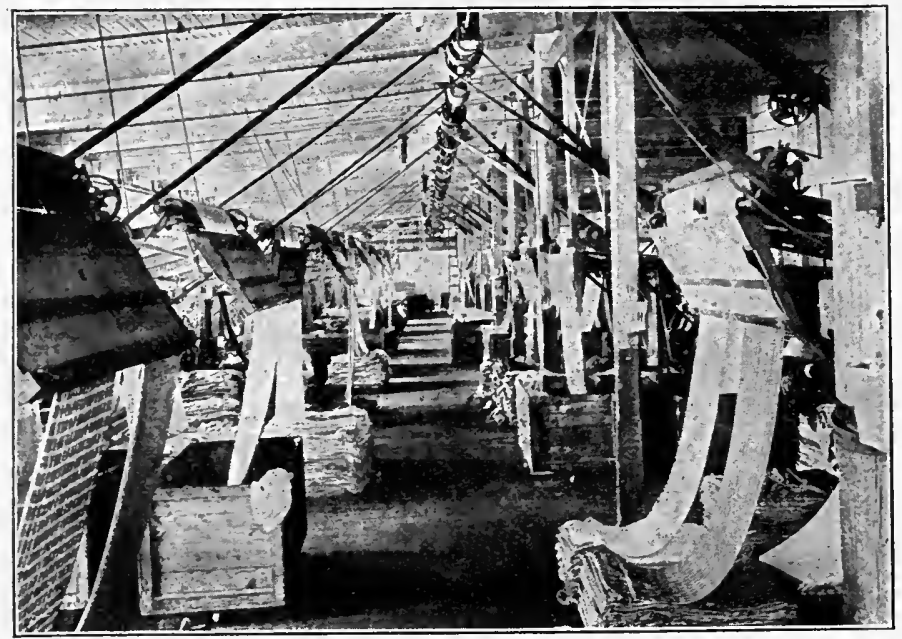

Courtesy of Marshall Field \& Company Napping and finishing blankets and outing flannel in a North Carolina cotton mill.

slaves, where education was a private matter, and where schools were supported primarily for the benefit of a few.

The Cotton Manufacturing Industry. The following tables show the state of the cotton manufacturing industry in the United States and foreign countries. Table A gives figures concerning the industry in the South; Table B, the industry in New England; Table C, the industry in the Middle Atlantic States, while Table D gives figures concerning the industry throughout the remainder of the world. 
TABle A

\begin{tabular}{|c|c|c|c|}
\hline State ${ }^{1}$ & $\begin{array}{c}\text { No. } \\
\text { SPINDLES }\end{array}$ & $\begin{array}{c}\text { Bales } \\
\text { Consumed }\end{array}$ & $\begin{array}{c}\text { BALES } \\
\text { IMPORTED }\end{array}$ \\
\hline Alabama $\ldots \ldots \ldots$ & 948,068 & 250,380 & 240 \\
\hline Arkansas $\ldots . . . \ldots$. & 13,724 & 6,325 & \\
\hline Georgia $\ldots \ldots \ldots$ & $1,813,096$ & 540,808 & 2,132 \\
\hline Louisiana $\ldots . . . \ldots$ & $69, i_{52}$ & I 5,949 & \\
\hline Mississippi $\ldots \ldots \ldots$ & I 59,468 & 37,522 & \\
\hline Missouri ......... & 30,276 & $16,7 \mathrm{II}$ & \\
\hline North Carolina ..... & $2,939,576$ & 756,677 & 3,217 \\
\hline South Carolina ..... & $3,715,894$ & 696,462 & 2,775 \\
\hline Tennessee ......... & 279,590 & 69,653 & \\
\hline$\ldots \ldots \ldots \ldots$ & 98,604 & 42,210 & \\
\hline Virginia $\ldots \ldots \ldots \ldots$ & 315,622 & 84,176 & \\
\hline All other Southern & & & \\
\hline States $\ldots . . . \ldots$. & I 5,496 & 20,954 & IO \\
\hline
\end{tabular}

\section{TABle B}

\begin{tabular}{|c|c|c|c|}
\hline State & $\begin{array}{c}\text { No. } \\
\text { SPINDLES }\end{array}$ & $\begin{array}{c}\text { Bales } \\
\text { CONSUMED }\end{array}$ & $\begin{array}{c}\text { FOREIGN BALES } \\
\text { IMPORTED }\end{array}$ \\
\hline Maine & $1,022,148$ & I6I,099 & 1,196 \\
\hline New Hampshire & $\mathrm{I}, 358,254$ & 278,457 & 3,422 \\
\hline Massachusetts ..... & $9,633,021$ & $1,321,572$ & 89,793 \\
\hline Rhode Island ...... & $2,368,409$ & 230,425 & 20,609 \\
\hline Connecticut .. & $1,285,792$ & I 42,685 & 84,995 \\
\hline
\end{tabular}

\section{TAble C}

State

New York ........

New Jersey ......

Pennsylvania ......

Maryland

$$
\text { No. }
$$

I,934,855

$472,6 \mathrm{r}_{4}$

384,474

I 53,290
Bales

Consumed

217,780

52,416

80,541

61,294
Foreign Bales

IMPORTED

3.711

84,058

5.557

1 In addition to the states mentioned in these tables the cotton factory is found in California, Illinois, Indiana, Kansas, Kentucky; Michigan, Ohio, Oklahoma, Wisconsin, and here and there in other states. 
TABLE D

\begin{tabular}{|c|c|c|}
\hline \multirow[b]{2}{*}{ CoUntry } & \multicolumn{2}{|c|}{ SOUTHERN COTTON CONSUMED IN BALES } \\
\hline & 1909 & 1880 \\
\hline Great Britain & $3,660,569$ & $2,433,255$ \\
\hline Germany & $2,394,369$ & 308,045 \\
\hline France & $\mathrm{I}, \mathrm{II} 4, \mathrm{I} 67$ & 359,693 \\
\hline Italy & $547,16 \mathrm{I}$ & 59,126 \\
\hline Spain & 301,545 & I 33,873 \\
\hline Belgium & $154,83 \mathrm{I}$ & 17,896 \\
\hline Russia & $95,45 \mathrm{I}$ & 204,500 \\
\hline Austria-Hungary & 95,875 & I,699 \\
\hline The Netherlands .. & 29,346 & 65,325 \\
\hline$\ldots \ldots, \ldots, \ldots, \ldots, \ldots, \ldots$ & 209,075 & \\
\hline Canada & I3I,976 & 19,619 \\
\hline Mexico ......... & $52, \mathrm{I} 46$ & 19,763 \\
\hline
\end{tabular}

From these tables it is easy to see to what countries the world looks for the production of manufactured cotton goods. More than seven million bales went to Great Britain, Germany, and France in 1909. It was in I880, however, that the Southern States turned seriously to manufacturing cotton: While the development in the South since that date has been very great, nevertheless many other countries of the world have shown an equal rate of progress. Germany has progressed faster than any American states, since she consumes more Southern cotton than all the New England states combined. Japan imported her first cotton from the South in I89I, and she consumes more Southern cotton than any Southern state except North Carolina, South Carolina, Georgia, and Alabama. Since I880 Italy, Spain, Belgium, Austria-Hungary, The Netherlands, Canada, and even Mexico have entered the world as competitors with 


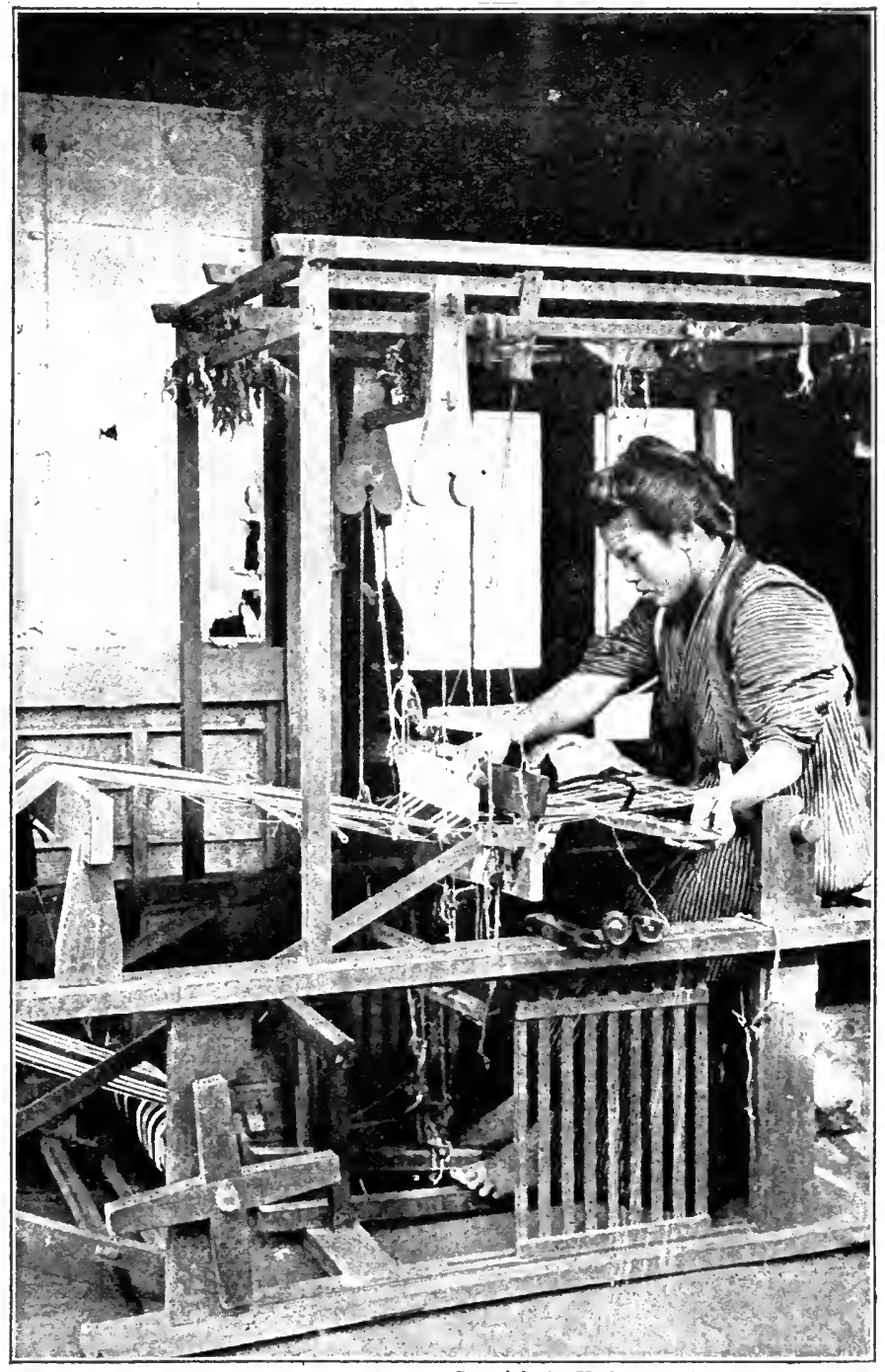

Copsright by Underwood \& Inderwood, $\mathbf{x}$. Y. Hand-loom weaving to-day in Japan, showing the peasant housewife at her work. 
America in manufacturing cotton. Success is largely a matter of skill, and skill will determine which country will control the markets of the world.

The use of machinery is an evidence of skill, and superior skill always produces a finer grade of goods. The Southern States consume more cotton than the New England States, but the value of the manufactured product in New England is greater than that produced in the South. Massachusetts, with three and a half times as many spindles as North Carolina, consumes only about sixty per cent more cottor. South Carolina is second in the number of spindles, but North Carolina is second in the amount of cotton consumed and third in the number of spindles. It was in Rhode Island and Massachusetts that the factory originally found its home in America, and there to-day is the center of the cotton manufacturing industry of America. The history of our industrial development for the first quarter of the nineteenth century tells how the factory was encouraged in New England. But this was many years after it was firmly established in, England. The arts of life were unfolding less rapidly in America than in England, and we must still look to England to find the center of the cotton manufacturing industry of the world. It was there the first machines were perfected, and it is there that the greatest activity is to be found to-day. Two thirds of the cotton produced in the South goes to Europe. But in the cotton states, where 
the fiber is produced and easily obtained, the total amount consumed is just about equal to that consumed by Germany, or less than one fifth of the whole production.

The South's Relation to the World. To be sure, great progress has been made, but the South is competing with the whole world, and every civilized nation is placing a premium on skilled labor and the finest machinery. The educational systems of the world are being utilized for making laborers more efficient, and all nations are working at the same problem: to produce the most skillful labor, to invent the most delicate machinery, and, by these agencies, to reach supremacy in the world's

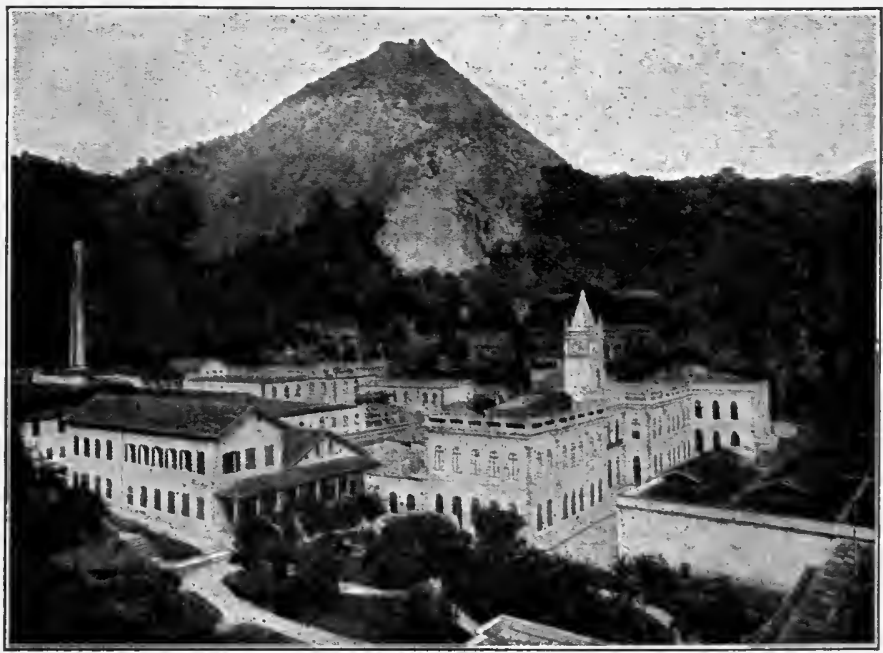

Courtesy of the Pan-American Union A cotton factory at Rio de Janeiro, Brazil. About one third of Brazil's industrial capital is invested in her cotton mills. 
business. This is the new empire that has been created in the last half-century. Its methods are opposed to warfare but always call for the development of skilled workmen and the union of skilled laborers by the aid of machinery into organizations ruled by captains of industry. This new empire is not confined to state and national lines. Its domain is world wide, wherever there are to be found similar skilled laborers working at the same business. New political problems have arisen as a result, and the problem of modern statesmen is to adjust the world's politics to this new empire of business and the conditions which go with it.

- The Piedmont sections of the South are a part of this powerful empire. But where shall the center of activity remain? If we judge by the skill of the laborers, England stands first to-day; Germany, second; New England, third; and the South, fourth. But if we judge by the amount of cotton consumed, England is still first; the South, second; Germany, third; and New England, fourth. But the value of a business is to be estimated not by its total output but by the skill of its workmen and the quality of the quantity produced. The South, therefore, will not move to first place until her skill can produce a total value that merits the first place. In other. words, the skill of her workmen must equal that of the workmen of the rest of the world.

The American Factory and the European Factory compared. In I9Io the United States imported $\$ 66,473$, I43 worth of manufactured cotton 
goods. This is an increase of about fifty per cent since I900. In I9I0 the United States exported

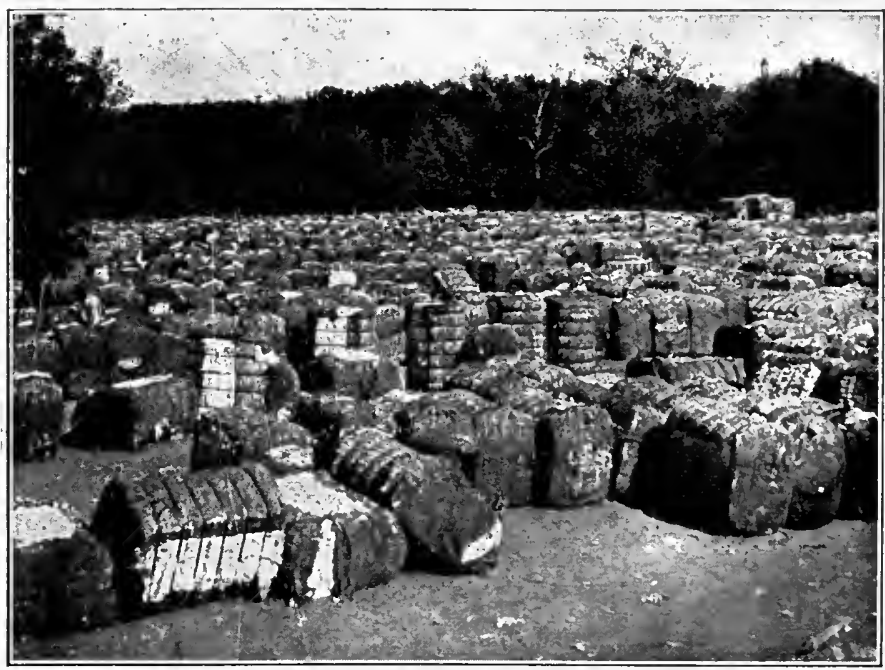

Copyright by Underwood \& Underwood, $\mathbf{x}$. $\mathbf{Y}$. Cotton baled ready for shipment. Part of the Texas four-million bale crop. Each bale weighs about 500 pounds.

only $\$ 33,398,072$ worth of manufactured cotton goods, which amount is an increase of only about thirty-five per cent since I90o. The imports from Europe consist chiefly of the finest goods made, such as laces, embroideries, velvets, plushes, and ready-made clothing. About $\$ 50,000,000$ worth of these goods were imported in I9Io from Great Britain, Germany, France, and Switzerland. The exports of the mills of the United States go chiefly to neighboring countries-Canada, Mexico, the West Indies, and South America, or to China and our insular possessions. The best markets for the 
American goods are those that are engaged in manufacturing cotton goods only to a very limited extent. The factories of America export a very small quantity of cotton goods to countries that have built up a large manufacturing business. On the contrary, the European mills ship large quantities of their goods into America. American skilled labor, therefore, is not yet able to compete with the skilled labor of Europe in the markets of the world. Even the increased exports of cotton goods from America have not kept pace with the increased imports of the finer goods.

The value of the raw cotton exported from America to foreign countries has almost doubled in ten years. Since Great Britain, France, Germany, Italy, Spain, Belgium, Russia, Austria-Hungary, The Netherlands, Japan, Canada, Mexico, and other countries are calling for American cotton, it appears that it is more economical for these countries to import raw cotton and manufacture it into fabrics than to import the cloth, even though it is of a coarser grade. About the only countries open to American goods are the less developed countries of South America and Asia. Even in these countries cotton may be produced, the factory may be established, and the doors may be closed to the coarser goods produced in America. These things have all taken place elsewhere since 1860 , for very nearly all the cotton shipped to Europe at that time went to the United Kingdom, France, and Germany. 
The American mills shipped to Europe in igro nearly five million dollars worth of manufactured goods. But more than half of the goods were "cotton waste," about the cheapest article produced in the mills. This is quite a contrast to sixty-six million dollars worth of laces, embroideries, and fancy clothing brought into this country.

Relative Value of Goods manufactured in the South. Manufactured cotton goods have many degrees of fineness, and each degree requires a different degree of skill in the production. The following table shows the value per pound of different grades of manufactured goods compared with the cost of raw cotton when cotton is selling at ten cents a pound:

\section{Grades of Cotton Goods}

Yarns, ducks, drills, prints............ to

Sheeting, bleaching, ticking $\ldots \ldots \ldots \ldots . \cdots$ to

Cheviot, denim, plain gingham.........4 to 6

Madras, long cloth ............... to I2

Mercerized cloth ................. I6

Fancy gingham $\ldots \ldots \ldots \ldots \ldots \ldots \ldots \ldots \ldots, \quad 25$

Poplin ......................... 30

Embroidered gingham .............. 35

Persian lawn ..................... 60

Embroidery
Value Compared with Raw CorTON

3 times

\author{
“"
}

6 “

"

6 "

5

(about)

"

5 “" “

60

300

Suppose we study the four leading manufacturing states in the cotton kingdom in order to see where the emphasis is placed.

Two thirds of the output of North Carolina factories consist of yarns, sheeting, print cloth, and drills, the cheapest grade of goods; about one fourth 
consists of checks, ginghams, denims, and plaids, while the remainder, or about one twelfth of the product, consists of fancy goods, high-grade dress goods, and sateens. The South Carolina mills produce a much smaller quantity of yarns, but about three fourths of their products are sheeting, shirting, drills, and print cloth, while about one sixth of the output consists of denims, ginghams, and ticking. Here twice as much of the finer goods is produced as in North Carolina. The product of the Georgia mills resembles that of the North Carolina mills, while the product of the Alabama mills resembles that of the South Carolina mills.

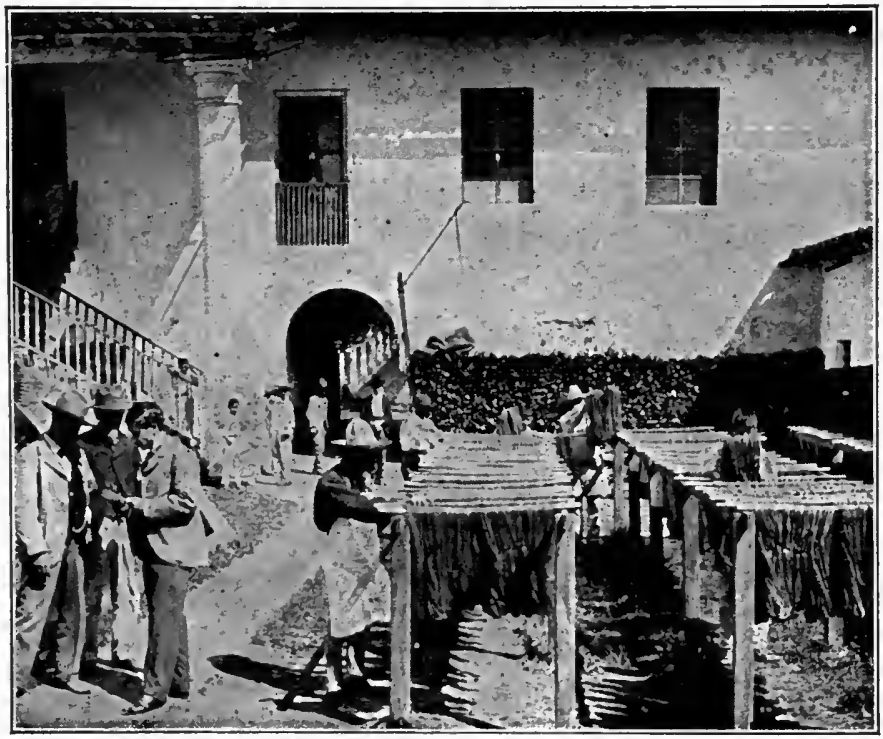

Copyright by Underwood \& Underwood, N. Y.

At a cotton mill, Jalapa, Mexico. Drying the skeins of yarm. 
The production of the finer goods in the South dates back only a very few years, and while the states mentioned are still in the first stages of cotton manufacturing, the development for the past decade shows that skill is improving. North Carolina and Georgia employ more labor to a machine than South Carolina and Alabama. This is another evidence that the two latter states use better machinery and produce a better grade of goods. But skill and the use of more highly developed machinery is increasing, since we find lawns, fancy goods, and mercerized goods beginning to come out of the South.

How a Bale of Cotton is treated when it reaches the Factory. In the days of the spinning wheel and hand loom the making of cloth was a comparatively simple process. But since the appearance of the improved machinery, manufacturing is so complicated that it sometimes takes years for an operator to understand the processes. Therefore schools are established in nearly all of the New England, Middle Atlantic, and Southern states, as ivell as in the leading nations of Europe, for the purpose of teaching the processes of manufacturing different grades of cotton goods. It will be of interest, therefore, to show here how a bale of cotton passes into cloth.

A bale of cotton, when it arrives at a factory, is carried into the mixing room, where the process of mixing the cotton with that of other bales is begun. Handful after handful of cotton is taken from the 
different bales and thrown into bins, those of the same grade being put together, and when this process is completed the pile is a thorough average. It is then run through a-machine which cleans it of all dirt and motes. It is next run through a series of machines where. it.is cleaned again and formed into a "lap" or "bat" or "roll." This process is called "lapping." It is next put through the processes of carding and combing. After this treatment the fibers are parallel except as they curl naturally and twist around other fibers. In order to stretch the curls and twists, the lap is next passed through the drawing frame, which stretches it out still farther and prepares it for the first twisting.

The product of the drawing frame is carried to another machine. Here the process is called, "slubbing," and the fiber is twisted and wound on" bobbins. These bobbins are carried to other ma-. chines which twist it still finer and wind it on smaller bobbins. The product is now called "roving," and is ready for spinning. All the work and processes mentioned so far.have been for the purpose of preparing the fiber for spinning. There are two methods of spinning,--mule spinning, which is the oldest, and ring spinning, which is used more generally in the United States and especially in the South. Spinning machines make of the roving a thread which is called warp or filling, which is wound on spools for weaving. Cloth consists of warp and filling, or, as it was called in the early 
days of the hand loom, warp and woof. It will be remembered that until the first machine for spin-

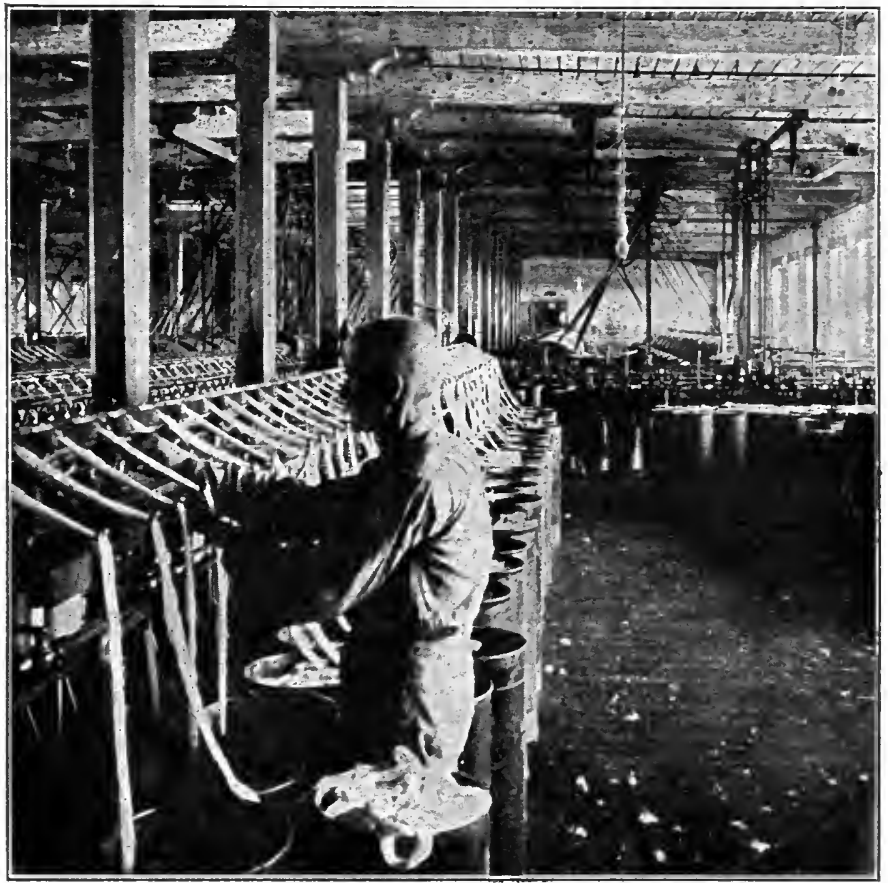

Copyright bs Keystone Vies Company Slubbing yarn in a cotton mill.

ning cotton was made the fiber could be used only for woof or filling, and had to be mixed with other thread made of stronger fiber before it could be used in making cloth.

The principle of weaving has never changed. The warp in the machine runs the long way while the filling is carried crosswise by rapidly moving shuttles, and weaving consists of entwining warp 
and filling in various ways in order to produce different designs of cloth. After the cloth is taken

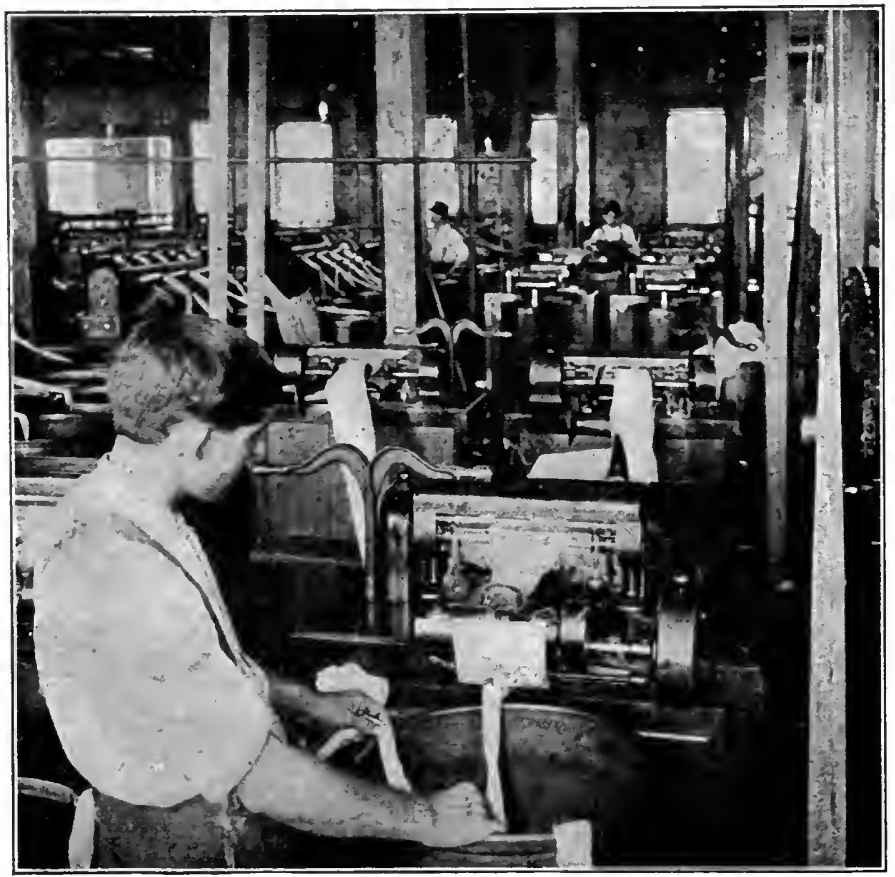

Copyright by Keystone View Company

Drawing sliver in a cotton mill.

from the loom in "cuts" or "bolts" it is carried to the cloth room, where a variety of machines are used for cleaning and finishing it. The term "finishing" is frequently used to designate bleaching, starching, printing, and dyeing. Some manufacturers, not being prepared for this kind of finishing, ship the cloth to other factories to be put through these processes, and the cloth thus 
shipped is called "converter's goods." A great deal of the goods that is manufactured in the Southern

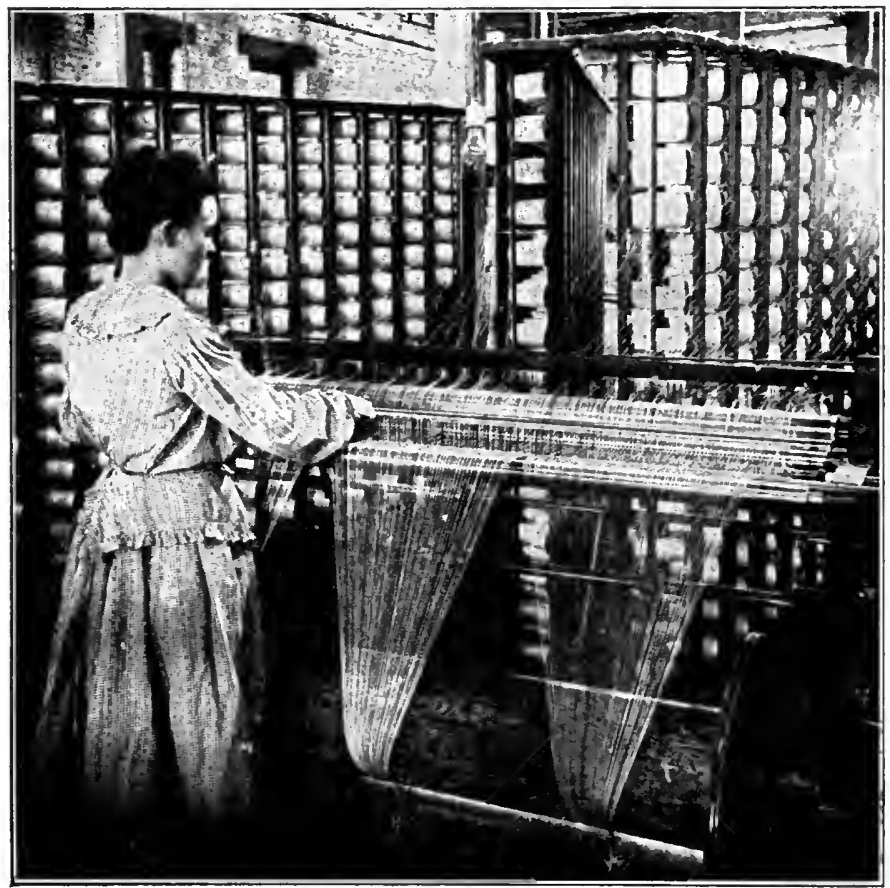

Copyright by Keystone Vlew Compang

Drawing in warp in a cotton mill.

States is sent to other factories to be "finished."

A New Problem in Education. Thus the machine and skilled labor have changed completely the habits, manners, customs, and even ideals of the people since the days of the old hand loom. A century ago woman's work was more clearly defined than it is to-day. There was a fairly accurate 
division of labor between the sexes, and women produced the greater part of the clothing of Amer-

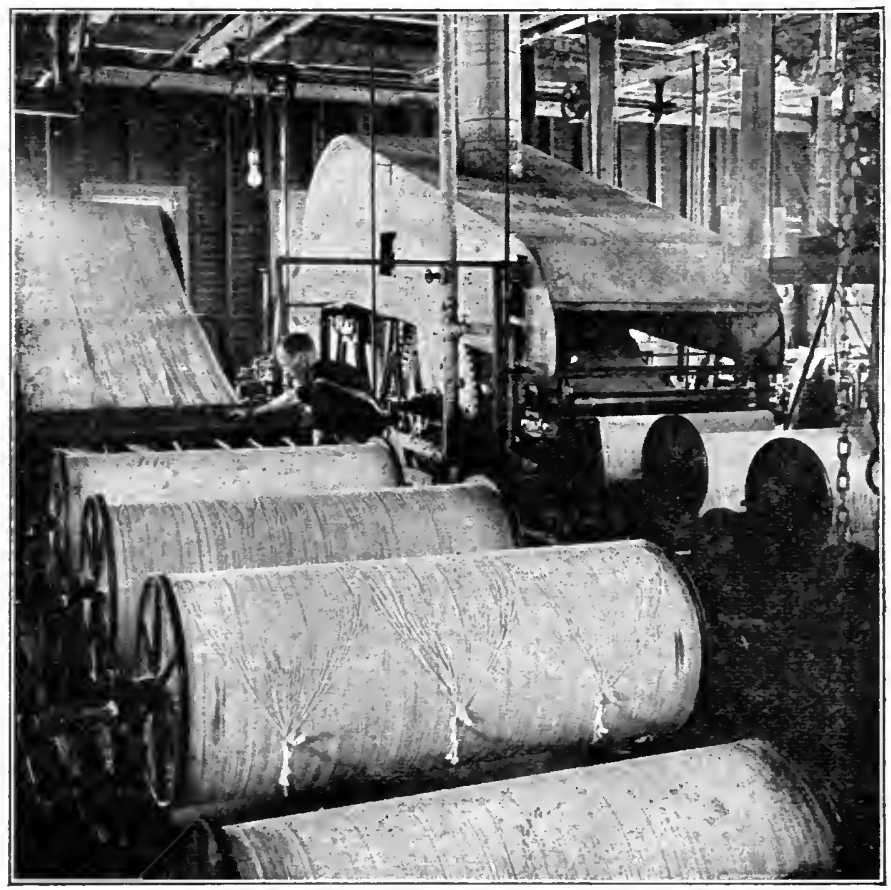

Copyright by Keystone View Conpary

Slashing or starching the warp.

ica. This industry has been taken out of the home and carried to the factory, and woman must look for other employments. Since education usually has some service in view, even though not of a definite character, the factory has produced an educational problem in taking a great part of woman's work from the home. Shall her education fit 
her for activities away from the home, or shall a new industry and a new science be created in the home and an entirely new educational system be developed?

Relative Importance of the Cotton Fiber. Two hundred years ago cotton was almost unknown to Europe. At that time clothing was made chiefly from wool, silk, flax, jute, hemp, or leather. Each of these products was easily obtained near the home. But while each is still easily obtained, cotton, through the aid of invention and skilled workmanship, has long dominated the whole kingdom of fibers, in spite of the fact that two thirds of it is produced in one small corner of the world, and the cotton business is now the greatest business in the world.

The following table shows the production of the different fibers in 1909 and the various countries in which they were grown:

TABle E

THE WORLD'S SUPPLY OF USEFUL FIBERS IN POUNDS

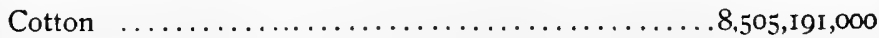

Wool $\ldots \ldots \ldots \ldots \ldots \ldots \ldots \ldots \ldots \ldots \ldots \ldots \ldots \ldots \ldots .2,695,622,000$

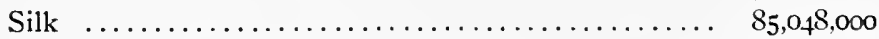

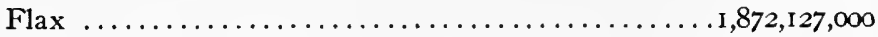

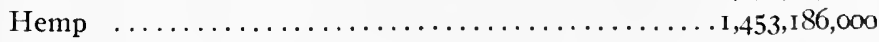

Jute $\ldots \ldots \ldots \ldots \ldots \ldots \ldots \ldots \ldots \ldots \ldots \ldots \ldots \ldots \ldots \ldots \ldots \ldots \ldots, 9,8,000,000$

Countries in which these Fibers are produced

Cotton: United States, India, Egypt, Russia, China, Brazil, Turkey, Peru, Mexico, and other tropical countries in small amounts. 
Wool: In every nation of the temperate zones except Japan, with Australia, Russia, Argentine, and the United States as the leading wool-growing countries of the world.

Silk: China, Japan, Italy, France, Austria-Hungary, and India Flax: Russia, Austria-Hungary, France, Italy, Great Britain, and the United States.

Hemp: Russia, Italy, Austria-Hungary, India, France, and Japan. Jute: Principally in India.

\section{The Commercial Importance of Cotton. The} value of the American cotton fiber in 1909 was estimated at seven hundred million dollars, and the value of goods manufactured from it at two billion dollars. It is estimated also that about ten million persons are employed in its production, manufacture, and commerce, and fifty million men, women, and children, more than the whole population of the South, are dependent upon it for food, clothing, and shelter, so extensive is the empire of the cotton kingdom.

A century ago wool was the king of clothing. It was produced in every country of the globe and was universally accepted as the chief article of clothing. But to-day one small section of the earth produces a fiber so wonderful in its nature that it is used wherever civilized man is found, and the commerce of it, reaching from the South to the utmost limits of the world, is binding the nations together in similar manners, customis, and occupations. Every nation of the world has its fiber. Australia produces the most wool; China the most silk; Rusșia, the most flax and hemp; and India, the most jute, but each of these nations has also its 
cotton factory, each is improving the skill of its laborers for the purpose of manufacturing the cot-

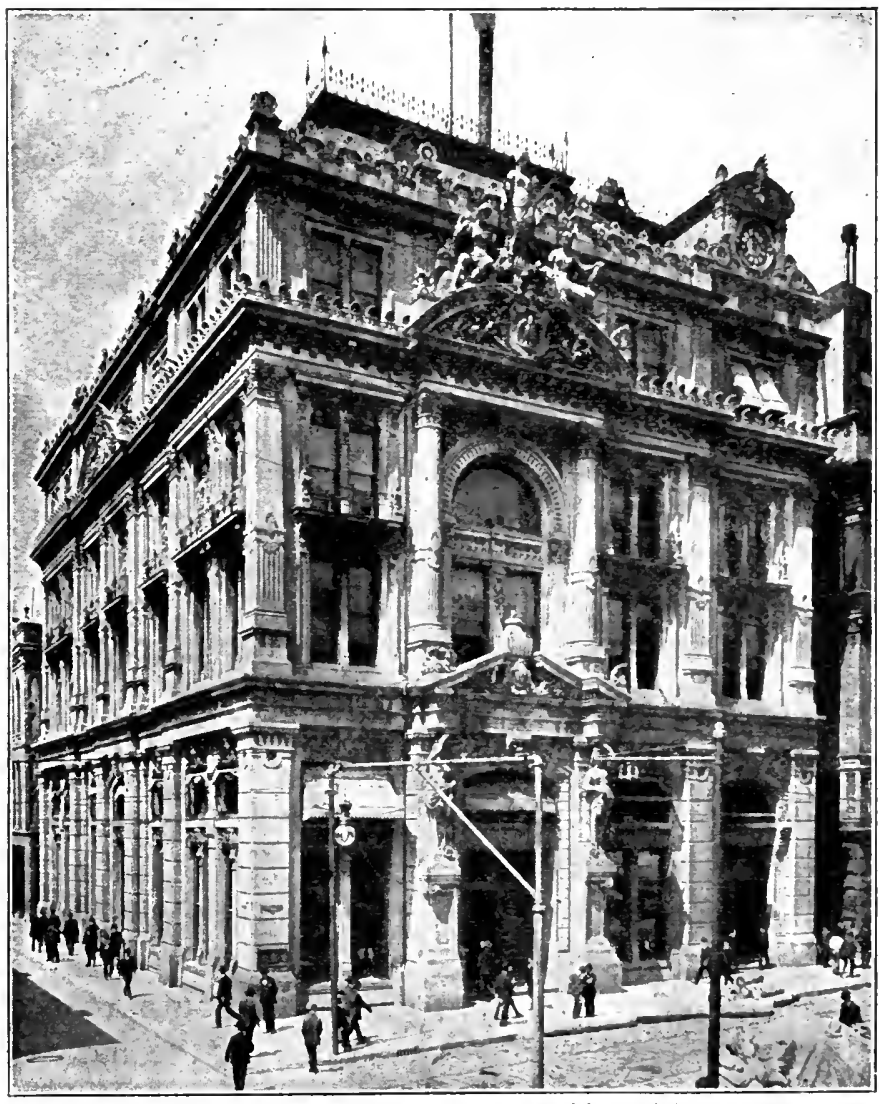

Copsright, 1903, by Detroit Photo, Co.

The Cotton Exchange, New Orleans, a great factor in the trade of the cotton kingdom.

ton of the South. It is with the skill of the world, therefore, that the laborers of the cotton factories 
of the South must compete, and the skill of the Southern factory laborers is not yet equal to that of the laborers of Europe, since sixty-six million dollars worth of the finest goods are imported from Europe, while this country is able to export only about half this amount, and that, too, of the coarser goods. 


\section{CHAPTER XIV}

Agriculture becomes a Science

The Mysteries of Mother Earth. It has ever been a mystery how seed go down into the darkness of the earth, burst open, and come back again in the form of new life. Ages ago this fabulous and mysterious underworld, with its strange and inexplicable processes, excited the profoundest awe and reverence in the inhabitants of the world. "The earth is the mother of all, and the stones are her bones," said the ancients.

The seed buried in the earth comes forth in the form of new life. This strange transformation that takes place down in the darkness of the earth finds many and various interpretations in the religions of the world. At one time it was believed that every living and moving thing in the heavens above or in the earth beneath proceeded from the earth and returned again in due season. Even the sun and the moon and all the stars were supposed to rise out of the earth and, after making the journey, each in its own way, returned with their gifts to the earth. Therefore Earth, the mother of all, was the great goddess from which had sprung all subsequent divinities and mortals. Jupiter was her son; Ceres was her daughter, and presided over the sowing, 
the reaping, and the harvest festivals; her name was mentioned in connection with the holy ceremonies and rites of death. Pluto, who ruled the underworld and was the giver of wealth and the lord of all that proceeded from the earth, was her son, and mortals, when they called on his name, beat the ground with their hands, and, averting their faces, offered sacrifice to him. Besides the many and confusing gods and goddesses that sent the plant up from the darkness beneath and guarded it as it grew to maturity there were scores of lesser divinities who ministered to the needs of the plant and brought it to full fruitage. The earlier races had a ceremony for every stage of its growth, and, when the harvest moon appeared and the crop had come. to its maturity, the heathen world broke out into unrestrained thanksgiving to nature's gods who, ruling the habits of the seed and controlling the growth of the plant, had brought man food in plenty.

Not only food came from the soil, but clothing likewise, and we are unable to go back to a time when people did not worship the strange forces that brought the little plant up out of the earth.

Agriculture a Sacred Obligation. In ancient Egypt tilling the soil was accompanied by religious rites. The inhabitants used the wooden plow, hoes, rude harrows, and rollers in cultivating the soil, in order that the gods that ministered to the plant might be friendly. They learned to irrigate the land and to supply the growing crop with moisture. 
Palestine, the land rich in green pastures, was famous for her agricultural products. Among the early Romans everything was sacred and every stage of the plant growth had its appropriate religious ceremony. There was a god of fallowing, of plowing, of sowing, of covering the grain, and of harrowing. There was a divinity that protected the grain in the germination, in the joint, in the sheath, and so on for every phase of the life of the plant. The Roman loved his herd and the welltilled land, and cultivating the soil was a part of his religion. The preparation of the land was itself regarded as a sacred obligation. He consulted the oracles, and dug deep seed beds to the depth of nine or ten inches; anything less than this was called "scarifying." He offered sacrifices to the goddess of the harvest and carefully cultivated the land. He learned the value of rotating the crops and draining the land, and the literature of the Romans served for centuries to furnish the best suggestions on agriculture.

The world was young then, and this wonderful life down beneath the surface of the earth had strange meanings and called for many strange rites and ceremonies. It was observed that man was absolutely dependent upon this hidden force beneath the earth for all the necessities of life, and even for life itself, and it was a great part of his religion to harmonize himself with this force. This he endeavored to do by prayer and fasting and offering sacrifices. Incidentally, however, he learned 
that he could work in harmony with these hidden forces and increase the productivity of the land.

Relation of Man to the Soil. Families, tribes, and nations, with their strange ceremonies, moved about on the surface of the earth and engaged in fierce struggles for the necessities of life, which came from this underworld of the soil. Yet in this soil and subsoil, about which man knows so little even to-day, there is always going on a struggle equally as fierce. This world of darkness is and ever has been teeming with life. Roots and rootlets, the great laborers of the plant world, go creeping about through the soil and on down into the subsoil, contending with one another in a perpetual struggle for existence. Ever working in and through the very texture of the earth's surface millions of living things, always working and always keeping the particles in motion, furnish life for the things that grow above. The problem with which the world has been struggling for ages is to establish a harmony between the things that live on the surface and the things that live beneath the surface of Mother Earth.

Man has learned much about the habits of people and the principles of government, and about the value of the plant world and the dependence of man upon plants, but little has been learned about this strange world beneath our feet, from which growing plants spring and from which they derive a great part of their sustenance. We do know today, however, that there are certain fundamental 
laws that control the habits of this life in the soil, and that by the use of intelligence and skill we have it in our power in a measure to produce this harmony between life on the surface of the earth and life beneath it.

The world has suffered untold miseries because of its ignorance of the soil. Famine, pestilence, destructive wars, and slavery have been the results of this ignorance during the long centuries through which the race has come. But from age to age, as these dire calamities have made their visits to man and have punished him sorely because in his ignorance and in his blindness he would not see the harmony that nature was struggling to teach him, a few, indeed, have seen the truth, and they stand out like prophets to the rest of mankind.

How Knowledge of the Soil has increased. When ancient people, after the fall of the Roman empire, ceased to make a religion of plant cultivation they trusted to luck or to chance, and each tribe or nation took from the surface of the earth what was produced with little effort and made war on the other tribes or nations in order to avoid starvation.

During the Middle Ages-that period which came to an end about the time Columbus discovered America-it was made an obligation of the Christian religion to cultivate the soil. Indolence was termed the enemy of the soul, and manual labor was first recognized as a necessary part of an educational system. In the cultivation of the soil the monks furnished models for the peasants of 
Europe; and the world was beginning to learn new processes for sustaining life.

Before the first settlements were made in America certain principles of plant growth were published in England, and were recommended to be taught in the schools of the day. Laws were passed to encourage better tillage. But it was not until near the close of the eighteenth century that the attention of practical men began to be directed to the discoveries of science, and hopes were excited that man would learn something about the vast possibilities of the soil. Lavoiser of France, the father of modern chemistry, was the first modern man to make an application of chemistry to agriculture. But his services came at a time when the soil of France was not equal to the demands of the age, and the farmers of that country, directing their rage against him as the probable cause of their misfortune, were responsible for his death. He was one of the victims of the French Revolution.

The wars of the latter part of the eighteenth century, which convulsed all Europe and drew the laborers from the field and left the land uncultivated, caused the world to turn seriously to the study of the soil. There was no new land in Europe, and the soil had to increase in productivity.

In I773 Denmark led in establishing schools for teaching agriculture. In I790 a chair of agriculture was established at the University of Edinburgh, and six years later one was established at Oxford. Then Austria, Germany, France, Norway 
and Sweden, Belgium, and other nations of Europe turned serious thought to the needs of the land.

Denmark to-day leads the world in the proportionate number of her agricultural high schools. Belgium, France, and Germany have their farm schools, and in many schools the soil is studied with as much care as is the human body.

Why America was Backward. While necessity was driving the nations of Europe to study the possibilities of the land America was such a vast and fertile country, and land was so abundant, that no attention was paid to the conservation of the fertility of the soil. It took the people several generations to find out that there was any limit to its productiveness. George Washington called attention repeatedly to the necessity of an increased knowledge of the possibilities of the soil. He and Benjamin Franklin were members of the first American Agricultural Society, which was established in Philadelphia in 1785 . In this same year a similar society was organized in South Carolina, which proposed to establish an experimental farm. These societies led to others in other states, and agricultural fairs were started. Yet with all this agitation there was a fine scorn for "book farming" among men who could raise phenomenal crops of wheat, corn, and cotton from virgin land. Even when this land was exhausted new land was at hand, and little need was felt for improving the soil.

By the close of the eighteenth century there were signs here and there, however, of exhausted 
lands in sections where land was hard to get. Columbia College of New York followed the exam. ples of the European schools, and in 1792 provision was made for teaching agriculture; in 1823 the first practical school of agriculture was established in Maine; three years later Connecticut moved in the same direction; in 1857 Michigan, a new state, took the lead in the study of the soil in America and provided in her constitution for creating agricultural schools; two years later Maryland and Pennsylvania turned in that direction; and in 1862 the Morrill Land Grant Act came into effect, which granted the proceeds of public lands to the several states and territories which might provide for the teaching of agriculture.

Interest in Agricultural Education. In this vast territory of America the possibilities of the soil have only recently been studied. New land will never again be so easily acquired; the present land must increase in productivity, and this calls for a knowledge of the soil. In I862 the national government established a department of agriculture, and in 1889 its head became a cabinet officer as Secretary of Agriculture. Agriculture is now taught in every state, territory, and outlying possession of the United States except Alaska. It is required by law to be taught in the rural public schools of Alabama, Georgia, Louisiana, Mississippi, North Carolina, South Carolina, Tennessee, and Texas of the cotton states, and Oregon, South Dakota, and Wisconsin of the Western States. 
Training courses for teaching agriculture are offered in state agricultural schools, state normal schools, and county normal and summer schools. Thus the educational machinery of the country has been employed to investigate this great underworld of the soil and to carry to the youth and to the adult some knowledge that will lead to a better understanding of its wonderful possibilities. It is still a mystery how seed go down into the darkness of the earth, into this mixture of sand, clay, and humus, and come back again in the form of a new life. This secret may never be known; but much has been learned about the habits of this new life as soon as its roots start downward and its stems start upward, and this new knowledge is fast changing the habits of men.

Why the South was more Backward. During the period from I850 to I 860 the land of the South depreciated in value. This was the decade that saw the rise of interest in agriculture in other sections of America, but the South, with its ignorant slave labor, entered but slightly into this new movement. The great war came which was to change the nature of her civilization and make her dependent upon improved soil rather than upon new land. Before this time little serious thought had been given to ways and means for improving the soil, since with slave labor and large plantations of fertile virgin soil there was little incentive to do. so. It was cheaper, for the time, to throw away old fields and cultivate new land. After the war 
the South turned rapidly to improved machinery and to manufacturing. Since that time exports of foodstuffs have been declining and our manufactured exports increasing. The soil has been losing its fertility; and at last the cotton kingdom has turned serious attention to the study of soil and of plant growth.

It was in Europe that necessity drove mankind to move from the old hand loom to the factory. Necessity also drove Europe from the old methods of tilling the soil to a more intelligent study of soil possibilities. In the South it was so easy to liveto supply the necessities of life-that there was little need for an intelligent study of soil possibilities until the land was practically all taken up and virgin soils began to show signs of exhaustion. But mankind has reached the last frontier, and the rites of the old mythological days are being repeated. Being unable to move farther, the inhabitants for the time beat the ground with their hands and call aloud for more knowledge of the soil which contains the life necessities of the world.

A Serious Problem. With all the progress that has come through the improvements of machinery and through careful seed selection, with all the labor-saving devices and all the improved varieties of seed, the land of the South as a whole is not as productive in the cultivation of cotton as it was thirty years ago. This would be more serious than it really is were it not for the fact that in certain states an intelligent study of the land has increased 
the productivity in certain counties more than one hundrea per cent, even within the last twenty years. Slave labor, or unskilled labor, served its generation well because the rich virgin soil would bring forth fruit in abundance with little effort and with little knowledge of the possibilities of the soil that was being ignorantly cultivated. We have seen a1ready how exhausted land was abandoned and new land was cleared. But a limit has been reached in clearing new land, and the fertility has barely been maintained during the last three decades.

Relation of Cotton Production to the Acreage. When the cotton gin was invented there were produced in the Southern States only about ten thousand bales of cotton, and about one third of this amount was exported to foreign countries. But to offset this the American states imported from foreign countries about five thousand bales, or one half as much as was raised in the South. The method of cultivation was very primitive, and the possibilities of the South as a cotton country were but faintly understood. The old wooden plow that scratched the surface of the land and the little hand gin that turned out only a few hundred pounds of lint a day were the only mechanical aids that the planter had in the cultivation. He knew little about the cotton plant and still less about the possibilities of the soil, and the land was ill-treated, until to-day it requires on an average more acres to produce a bale of cotton than it did in 1879 .

Since the invention of the cotton gin the South 
has been increasing the production by increasing the acreage. Seed selection, the improvements

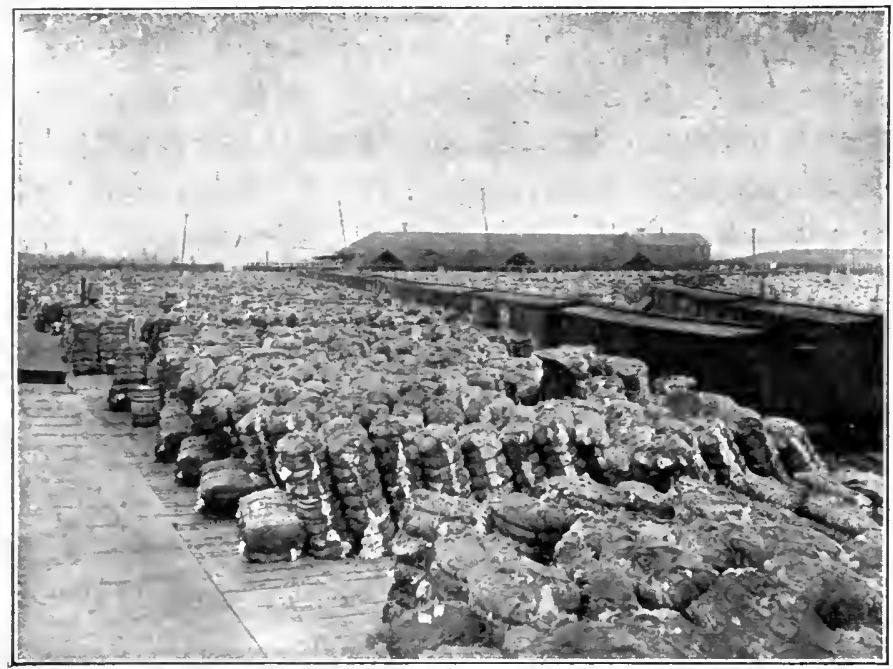

Copyright, 1900, by Detroit Photographic Company Cotton in the railroad yards at Savannah, Georgia. in machinery, and new methods of cultivation have been employed to increase the yield; but the land does not retain its original fertility now that fourteen million bales are produced where only ten thousand were raised a little more than a century ago, and the South as a whole has not yet learned to increase the amount of cotton produced by increasing the fertility of her soil.

In 1879 there was an average of 198 pounds of lint produced to the acre. Twice only since then, in 1897 and 1898 , has the average been higher than that. In 1879 there were $14,480,000$ acres of land 
used in the United States in cotton cultivation, which produced 5,755,000 bales of cotton. In I909. or thirty years later, the acreage was $30,938,000$, and the number of bales produced was I0,386,000. From these figures it appears that the amount of cotton produced has not increased at the same rate as the acreage has increased; for to-day there is about twice as much land under cultivation and less than twice as much cotton produced. It further appears from these results that so far the skill of the planter has barely succeeded in maintaining the original fertility of the land; and in many instances where this has been done it is due to throwing away old land and clearing new.

The following table shows how the acreage and the number of bales have increased or decreased during the last thirty years:

\begin{tabular}{|c|c|c|c|c|}
\hline \multirow[b]{2}{*}{ State } & \multicolumn{2}{|c|}{1879} & \multicolumn{2}{|c|}{1909} \\
\hline & ACREAGE & Bales & ACREAGE & BALES \\
\hline Alabama.... & $2,330,086$ & 699,654 & $3,471,000$ & $1,065,377$ \\
\hline Arkansas .... & $1,042,976$ & 608,256 & $2,218,000$ & 718,117 \\
\hline Florida $\ldots \ldots$ & 245,595 & 54,997 & 237,000 & 62,936 \\
\hline Georgia $\ldots . .$. & $2,617,138$ & $8 \mathrm{I} 4.44 \mathrm{I}$ & $4,674,000$ & I,90I,830 \\
\hline Louisiana . . & 864,787 & 508,569 & 930.000 & 269,573 \\
\hline Mississippi .... & $2,106,215$ & 963 , I I I & $3,291,000$ & $1,109,580$ \\
\hline Missouri & 34,783 & 21,685 & 70,000 & 52,152 \\
\hline North Carolina & 893,153 & 389,598 & $\mathrm{I}, 359,000$ & 649,886 \\
\hline Oklahoma $\ldots .$. & 35,000 & 17,000 & $1,767,000$ & 573,786 \\
\hline South Carolina. & $1,364,249$ & 522,548 & $2,492,000$ & I, 164,309 \\
\hline Tennessee ..... & 722,562 & 330,621 & 735,000 & 253,397 \\
\hline Texas & $2,178,435$ & 805,284 & $9,660,000$ & $2.554,520$ \\
\hline Virginia ...... & 45,040 & I9,595 & 25,000 & 10,746 \\
\hline Mited states. . & & 000 & 000 & I0,386,000 \\
\hline
\end{tabular}




\section{The Per Cent of Increase or Decrease in Produc-} tion. In I879 Louisiana was raising more than a half bale, or about 29I pounds of cotton per acre, which was the highest yield of any Southern state. Arkansas came next, and North Carolina third. Since then Louisiana and Arkansas have fallen far behind. North Carolina takes first place. The productivity of the latter state, however, shows an increase of only twenty-two pounds to the acre, while South Carolina and Georgia come next in productivity, and show the greatest gains.

The following table shows the percentage of increase in acreage and production from 1879 to I909:

\begin{tabular}{|c|c|c|}
\hline State & $\begin{array}{l}\text { Percentage of } \\
\text { INCREASE IN } \\
\text { ACREAGB }\end{array}$ & $\begin{array}{l}\text { Percentage of } \\
\text { INCREASE IN } \\
\text { Production }\end{array}$ \\
\hline United States $\ldots \ldots \ldots \ldots \ldots$ & I I4 & 80 \\
\hline Alabama $\ldots . \ldots \ldots \ldots \ldots$ & 53 & 52 \\
\hline Arkansas $\quad \ldots \ldots \ldots \ldots \ldots$ & 111 & 18 \\
\hline Florida $\ldots \ldots \ldots \ldots \ldots \ldots$ & 3 (decrease) & 14 \\
\hline Georgia $\ldots \ldots \ldots \ldots \ldots \ldots$ & 78 & 132 \\
\hline Louisiana $\ldots . . . .$. & I0 & 47 (decrease) \\
\hline Mississippi $\ldots \ldots \ldots \ldots \ldots$ & 56 & I6 \\
\hline Missouri $\ldots \ldots \ldots \ldots \ldots \ldots$ & $106^{\circ}$ & 140 \\
\hline North Carolina .......... & 52 & 67 \\
\hline Oklahoma ............ & 4934 & 3274 \\
\hline 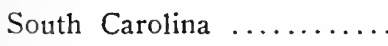 & 82 & 123 \\
\hline Tennessee $\ldots \ldots \ldots \ldots \ldots$ & 2 & 23 (decrease) \\
\hline Texas $\ldots \ldots \ldots \ldots \ldots \ldots$ & 243 & 217 \\
\hline Virginia $\ldots \ldots \ldots \ldots \ldots$ & 45 (decrease) & 45 (decrease) \\
\hline
\end{tabular}

In Louisiana, Mississippi, and Texas the cotton crop for 1909 was seriously damaged by the boll weevil. This accounts to some extent for the great difference between the increase in acreage and in 


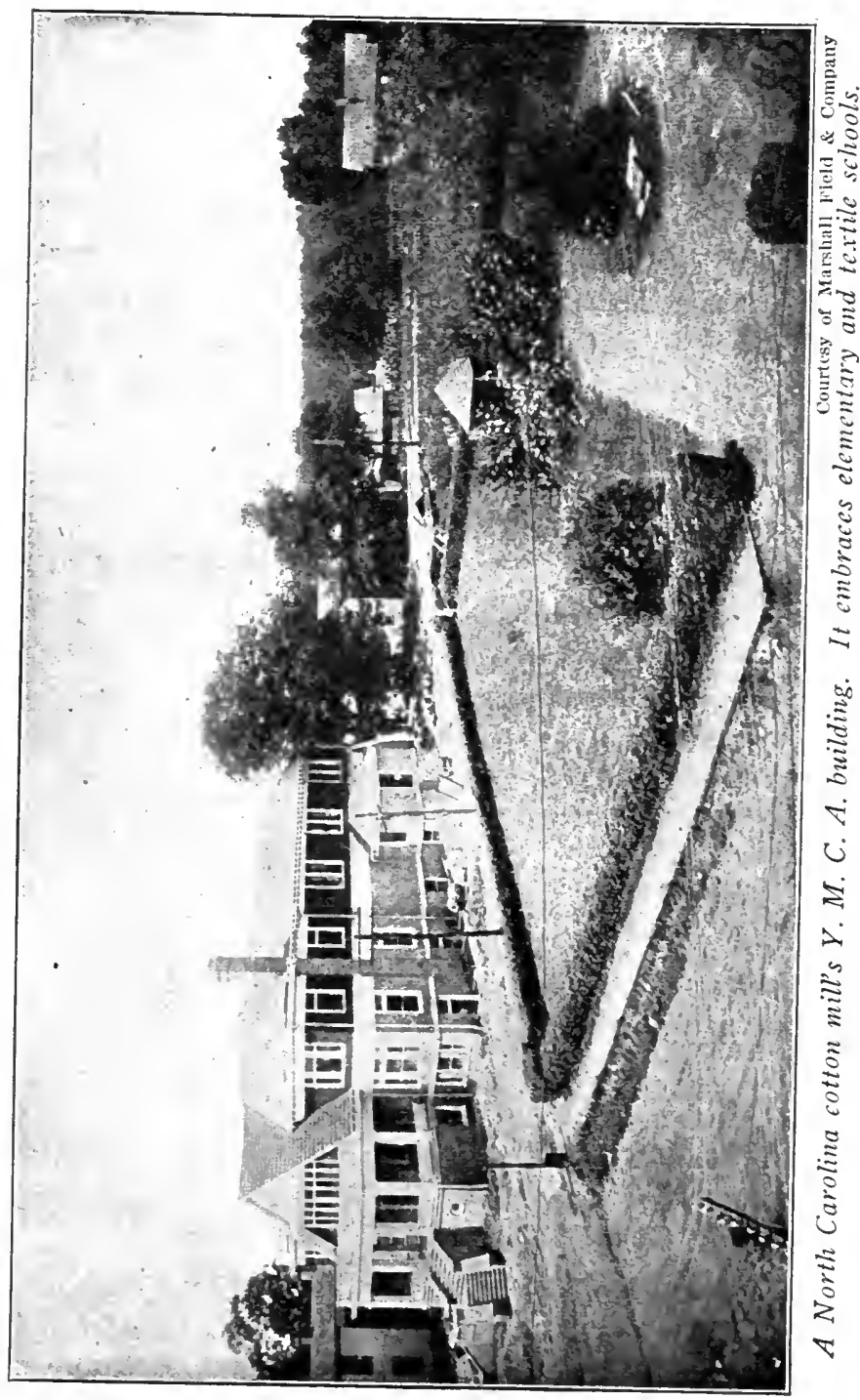


production. And this enemy to cotton production must be reckoned with in the future.

It is interesting to note that cotton production has increased faster than the acreage in Florida, Georgia, Missouri, North Carolina, and South Carolina. In other words, these states are raising more cotton per acre than they did in 1879. Georgia and South Carolina have shown wonderful progress. The land has almost doubled in its productive value, with the greatest increase in Georgia. In North Carolina there has been a good increase; but in Virginia there has been a decrease in acreage and a like decrease in production. But in Arkansas, Louisiana, Mississippi, Oklahoma, Tennessee, and Texas there is considerably less produced to the acre than in 1879 . There has been a slight decrease also in Alabama.

It will be observed that the acreage in Florida has decreased over eight thousand acres, but the production is greater by eight thousand bales than it was in 1879. In Virginia the acreage and the production have decreased at about the same ratio. In Tennessee, where the acreage has increased but little, the production has decreased twenty-three per cent. The greatest increase in acreage and in production has been in Texas and Oklahoma, where new lands have been opened to the public. In Texas more than four times as much land is in cotton cultivation, but the production has not kept pace with the acreage, for only about three times as much cotton was raised there in 1909 as in 1879 . 
The states of Texas, Louisiana, and Mississippi planted in cotton in 1909 about $14,000,000$ acres, and produced only about 4,000,000 bales-that is, I 43 pounds of lint cotton to the acre-while the Atlantic States, North Carolina, South Carolina, and Georgia, with $8,700,000$ acres of cotton, produced 3,800,000 bales, almost as much, while the average yield per acre was 220 pounds. If we study the cotton states as a whole we see that the acreage has increased one hundred fourteen per cent; but the production has increased only eighty per cent. The land as a whole, therefore, is thirty-four per cent less productive than it was thirty years ago.

Production by States. The following table shows the average yield of lint cotton per acre. There are about five hundred pounds of lint cotton in a bale. Hence from these figures it can easily be seen how much land is needed to produce one bale of cotton.

Number of Pounds of Lint Cotton per Acre

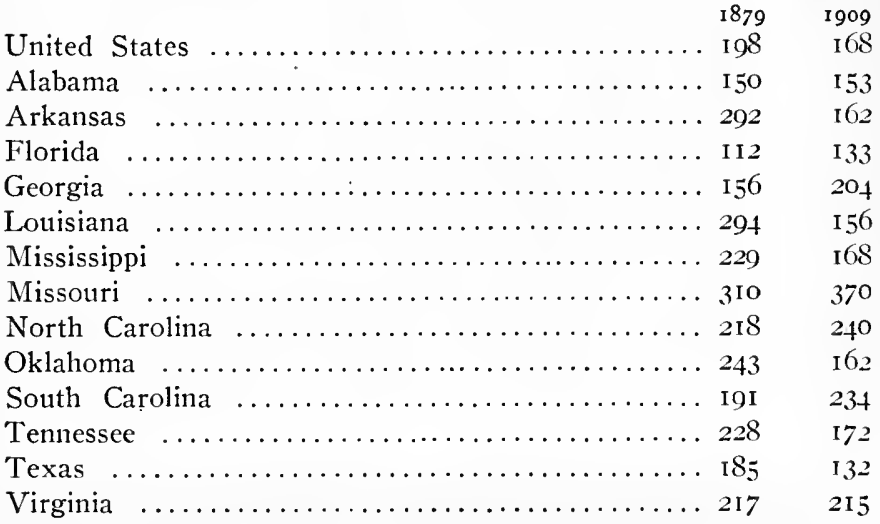


From this table, leaving out Missouri, Florida, and Virginia, where a comparatively'small amount of cotton is produced, it appears that North Carolina land yields more on an average than that of any of the other Southern states; South Carolina is second and Georgia third. Texas shows the least amount to the acre, Louisiana next, and Alabama third from the bottom.

If we study the production by counties we find that Marlboro County, South Carolina, produces the most cotton to the square mile, the amount being I 32 bales; Terrell County, Georgia, comes next with I00.5 bales; and Coahoma County, Mississippi, is third, with 90.2 bales. The states showing the largest increase in production per square mile are South Carolina and Georgia. The effect of improved methods of cultivation and a better understanding of the wonderful possibilities of this great soil world is reflected in the statistics for South Carolina and Georgia. In the latter state the acreage has increased in thirty years seventy-eight per cent, while the production has increased one hundred thirty-two per cent; in other words, an acre of land is made to produce fifty-four per cent more cotton than it produced thirty years ago. In South Carolina the acreage has increased eightytwo per cent, while the amount of cotton produced has increased one hundred twenty-three per cent. In that state an acre of land produces forty-one per cent more than it did thirty years ago. An excellent illustration of what the soil will do when its 
nature is understood and when it receives good treatment is afforded by the statistics of Marlboro County, South Carolina. In I 889 it produced 63.5 bales of cotton to the square mile; but in I909, just twenty years later, it produced 32 bales to the square mile-a gain in productivity of over one hundred per cent.

History relates that the intensive system of farming, which involves a thorough preparation of the soil, the use of commercial fertilizer, rotation with leguminous crops, and rapid and intelligent cultivation, had its beginning in this county about I 857 .

Character of the Land. What is the character of this soil in the cotton kingdom that it will produce such varying amounts to the acre? By studying the character of the land from the Ohio and Potomac rivers to the Gulf of Mexico, and from the Atlantic coast to the Rio Grande, we find every variety of soil and every land formation from the level alluvial plains of the coast and river bottoms to the rugged slopes. of the mountain peaks east of the Rockies. Cotton is grown in every variety of the soil from the seacoast to the foot of the mountains. There are of course many counties along the coast where cotton is not grown, and its cultivation ceases at an altitude of from five hundred to eight hundred feet.

In studying the territory east of the Mississippi River the cotton land may be divided into three general categories, according as it rises from the 
Atlantic and Gulf coasts and slopes toward the mountains. The first division is the level land, extending from the coast to about an average of one hundred miles inland and to an altitude of about two hundred feet. Very little cotton, comparatively speaking, is produced here, only about three per cent of the total crop. The next division is the hilly land, which extends from the level lands to an elevation of about four hundred feet. Following this is the Piedmont land, which, as the name indicates, is far beyond the fall line, and extends to the foot of the mountains, where cotton production ceases. In these two latter divisions is grown about one third of the cotton produced in America. The leading cotton counties of North Carolina, South Carolina, Georgia, and Alabama are embraced in these two divisions. Leaving the land that slopes mountainward, we have the prairie land on both sides of the Mississippi-the black prairies of Alabama, Mississippi, Louisiana, and Texas, and the red loam prairies of Texas and Oklahoma. About one fourth of the American cotton crop is produced on this land. There is another variety of land which, though not so extensive in area, is the most fertile of all the cotton lands. This is the alluvial land of the river bottoms, and especially of the Mississippi, the Red, and the Brazos rivers. So rich is the soil in these three river valleys that it produces about one sixth of all the cotton grown in America.

In addition to these we have what is known as 
the oak and hickory regions that border on the prairie lands; the bluff and brown regions that extend from Baton Rouge, Louisiana, to the Ohio River; the red-loam lands of Arkansas and Mississippi; and the sand-hill regions that extend through sections of North Carolina, South Carolina, Georgia, and Alabama.

Varieties of Soil. The character of the land therefore is different in different states and even in different sections of the same state. So varied is the land and soil that even two adjoining plantations may be entirely different and may need entirely different treatment. But the thin surface layer, where the life of the plant world finds its home, has a texture or structure that can be understood. Its value or productivity is determined by its texture, and this depends upon the mixture of sand, clay, and humus (decayed plant and animal matter) which enters into its composition. It is usually classified as sandy, clay, humus, or loam according to the element which predominates in the mixture.

Sandy soil is made up principally of sand with a little mixture of clay or humus. When it is wet it will stick together, but as soon as it is dry it readily falls apart. The clay soil is of different colors, sometimes red, sometimes almost white, sometimes brown, and sometimes nearly blue. When it is wet it can be molded into any shape, but when it becomes dry it is very hard and keeps its molded shape. It is much heavier than sandy soil. Humus 
soil, as its name indicates, contains a great deal of humus, or decayed vegetable matter. It is found in low pasture lands, in river lowlands and bottom lands, and in swampy, marshy sections. It is composed almost entirely of decayed vegetable matter washed down from the hills or mountains. Sometimes it is several feet deep. A loam soil contains a mixture of sand, clay, and humus; and such a soil is best fitted for growing most of the crops of the farm.

This strange mixture of sand, clay, and humus, and the chemical elements found in them, are today attracting more attention than ever before in the world's history. The possibilities of this mixture when exposed to heat, water, and air form the basis of a new science; for food and clothing must come out of this strange world of soil,- -and as population increases the land must increase in productivity, since all life finds its food in these strange compounds. 


\section{CHAPTER XV}

\section{The Cultivation of the Soil}

The Beginning of Soil Study. By observing deep cuts in the land through which a country road or a railroad has been built the layers of the earth formation can be easily studied. On the surface are seen grasses, weeds, bushes, and trees. Just beneath, only a few inches deep in most places, is a dark-colored earth which we call soil, and which contains a large part of the available food for plants. Underneath this layer is earth of another color called subsoil, which is generally much harder and more difficult to cut or dig up. It will be observed that roots of various plants work down into the subsoil; for here food is to be found also, and much moisture as well.

It is the soil, therefore, the thin top surface layer with its mixture of sand, clay, and humus, that the world has depended upon for food, clothing, and shelter. This is the home that nature has provided for all plants, and as the roots go creeping about in the soil and on down into the subsoil we know that they are seeking food with which to nourish the growing plants that cover the surface of the earth and keep mankind from perishing. If we analyze a handful of this dark-colored earth we find fine 
particles of rock, and fine black substances which we know to be decayed plants or animals. If we examine it still more carefully we discover certain mineral elements in the mixture which we may find also in the analysis of the plant, and we know this mineral matter is in some way carried from the earth, made into a vailable food, and built into the plant. By observing the habits of the roots we learn that they are going about through the soil and on down into the subsoil, and in some mysterious way are taking up these food elements and sending them up the stems, limbs, and leaves for the use of the plant. It was observed as early as the thirteenth century that one crop cultivated year after year would soon exhaust the food elements in the soil necessary for that crop. It was next observed that man might add certain things to the soil, such as stable manure or ground bone, with the result that the food of the soil would be increased. It was known two thousand years ago that a deep soil produced a better plant than a shallow soil. These observations were valuable. Others equally as valuable have been made from time to time, and from them has developed a science of agriculture.

Soil the Home of Plants. When man builds a home for himself and family he provides food, water, air, and the comforts of the body. With these provided, the natural or acquired activity of the individual determines his worth to the world. When nature builds a home for her family of plants 
she provides food, water, air, and the comforts of the plant body. With these provided, the growth

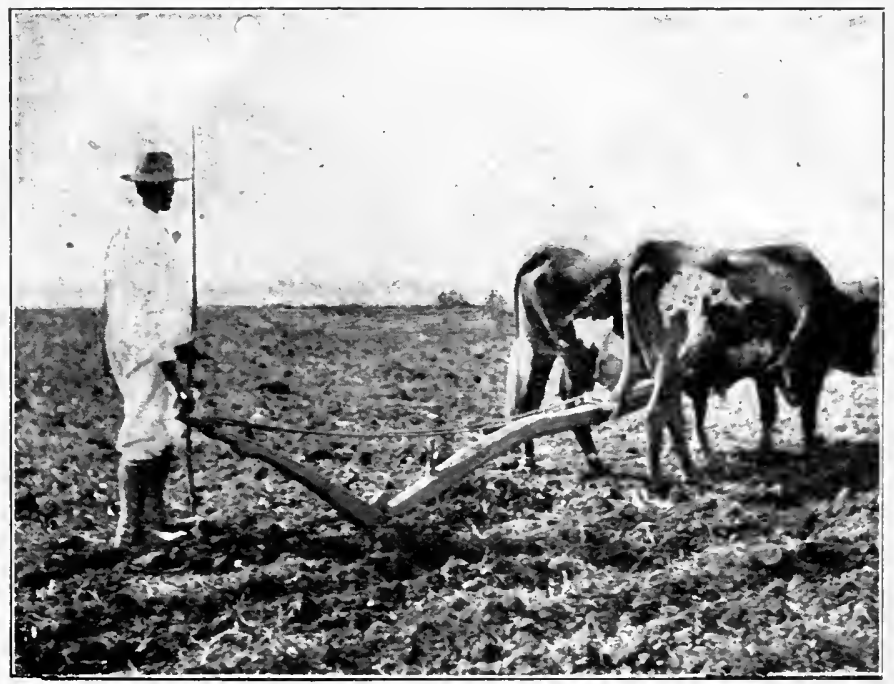

Courtesy of the International Harvester Company

Shallow plowing: Preparing the soil for a poor crop.

is determined by the potentialities of the plant. Many tender plants wither away and die because the vigor of other plants crowds them out and robs them of their food. In order, therefore, for them to live and reach maturity man must come to their assistance and see that food, water, and air are supplied in sufficient quantities, and that other plants do not enter their home and steal away these necessities. This care for the plant growth is called cultivation.

All the improvements in machinery, from the crooked stick and the old wooden plow to the 
highly developed harrows and cultivators and gang plows moved by steam power, have for their pur-

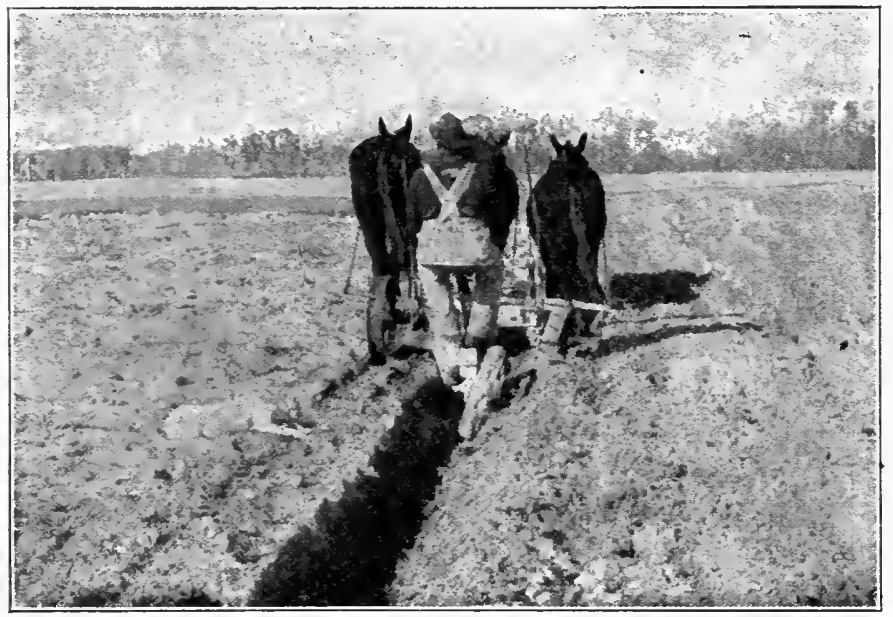

Deep plowing: Preparing the soil for a good crop.

pose the preparation of a better home for the roots of the plants-a home deep in pulverized soil, containing moisture, and through which air and warmth may penetrate with ease. But how to make a home for plants, how to produce a good deep, pulverized soil, how to make food for plants where none already exists, and how to make plants grow luxuriantly where the food supply is running short, these are comparatively modern acquirements.

How Nature teaches Man. Long before man learned to till the soil, nature year in and year out was working the soil over, adding new material, and making it more fertile. She was grinding 
the rocks into small particles, depositing leaves, grasses, and trunks of trees, and mixing their decomposed bodies with the fine particles of rocks. The wind and rain were mixing them and transporting them from place to place and stirring the mineral elements that contained the food for life. There were also other agencies at work which kept the surface of the earth always in a state of change. Roots of the plants and trees were plowing down into the soil and subsoil.; plants were sending down their foliage and themselves decaying and falling back to earth. Then camer the common earthworm, and millions of other living organisms that bored into the land, eating dirt, changing the chemical compounds, and mixing the substances from which plants might draw food. Thus nature is always at work in the soil, with a tendency to make it loose, friable, and capable of receiving warmth, air, and moisture. But the work of nature alone is not sufficient for certain plants. Man, by understanding nature's processes, can work in harmony with them, and by coöperating with nature, increase the productivity of the land. All the progress of the world is due to man's ability to understand and to work in harmony with the forces of nature. Three thousand years ago, when man was in a very primitive state, and when he plowed with a crooked stick, sailed the seas in tiny boats, made his clothes from coarse grasses, hunted with the club, the spear, or bows and arrows, the same forces of nature existed as exist to-day. But in unfolding the 
arts of life man has seen more clearly from age to age his kinship with nature, and the progress of to-day is due to the teachings of nature and man's readiness to be instructed.

The Plant's Need of Food. The difference between a scrubby plant eking out a bare existence on some wasted and washed-away hillside and a rich, vigorous, well-fruited plant is due to differences in soil, climate, and cultivation. Nature originally gave the growing plant the soil and the climate, but nature's processes are sometimes too slow for the needs of man, and by working in harmony with nature he may improve the fertility of the soil, quicken the growth of the plant, and produce an entirely new species. We have seen already how careful seed selection will improve the quality and the quantity of cotton, provided the plant gets sufficient food; for it, like the human being, cannot thrive, it matters not how carefully the seed is selected, unless the food is sufficient to give it proper nourishment. It, like the human being, is subject to all kinds of diseases if its constitution is weakened through lack of attention.

The present cotton plant is the result of long years of study and constant improvement. If a seed is cut open and examined carefully there will be found wrapped in the hull the germ of a tiny plant and food sufficient to support it until it can put forth its roots with which to get food from the soil and air. So nature has not only given soil and climate but has stored up enough food in the seed 
to start the plant off and develop some leaf and root surface.

This germ found in the seed has all the characteristics of the preceding generation of that species, and, if it is neglected, it will have a tendency to revert to the original scrubby plant that is almost as unproductive as the plant that grew wild two hundred years ago. The poor, scrubby plant seen here and there, trying to grow in impoverished soil, and cultivated by ignorant, shiftless labor, has already started to undo all that skill and science has done for it, and seed from such cotton, replanted, will produce inferior quality and quantity. The chief trouble with it is insufficient food. It harmonizes very well with a poor mule and a ragged negro, for all these are suffering from the same lack.

Most people are acquainted with the little sour crab apple, and all people love the large pippin that finds such a ready sale in the markets of the world. This fine apple came from the little sour crab apple after years of careful cultivation; but if it is neglected for a few generations it will revert to the old type. So it is with the cotton plant. The present high-grade variety came from a scrubby plant that was little productive two hundred years ago. To-day three or four bales of cotton may be produced from one acre of land, but if the plant is neglected it has a tendency to revert to the original scrubby plant that was so hard to understand when it first grew in the colonies. 
How Food is secured. As the first necessity of man is food, so it is with the plant; and without food neither can live. Nature has made it possible for each to secure food, but each has to prepare it for its own use. The soil is therefore the home of the plant. It is there that food is stored; but its use is determined by the structure of the home, which, as has been said, is composed of fragments of rocks and decayed plant and animal matter. These, however, make merely the texture or structure of the home, and in themselves are no more plant food than the timbers which make up the storeroom are the food for man. They merely contain the food. In this mixture of fine ground rock and decayed plants and animals there are, however, certain plant food elements, a mong which are nitrogen, phosphoric acid, and potash.

These are the leading food elements in the soil, and plants seek these in such quantities that, after cultivating the land for a few years, these leading elements are used up, the productivity decreases, and we say the land is exhausted or "worn out." In order to prevent this exhaustion, the planter must find some way of restoring the food elements to the soil, either by adding them or by bringing them up from the subsoil.

These food elements are formed in the fine particles of soil, and the finer the particles the easier it is for the roots to secure the food. A large rock contains plant food, but only a few plants, such as mosses and clinging vines, are able to use it, and 
these only after particles have disintegrated. Hard lumps of earth and the compressed and undisturbed

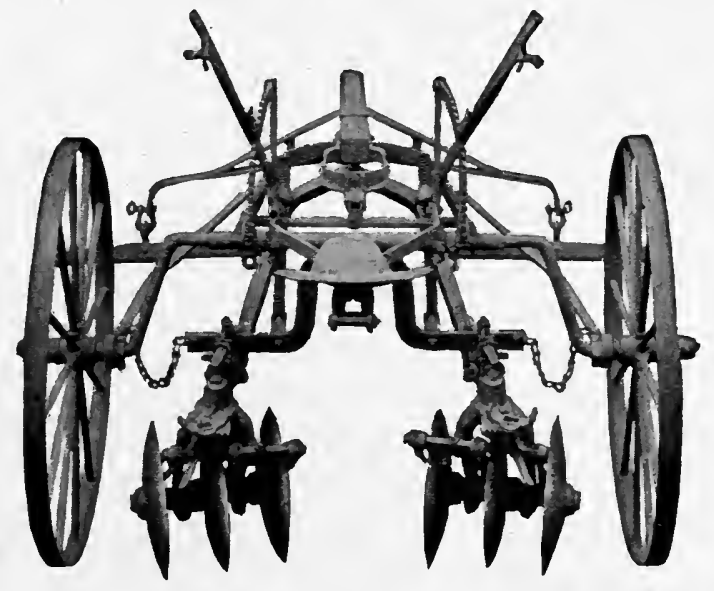

Courtesy of B. F. Arery \& Sons

$A$ disk cultivator.

subsoil contain some plant food, but it is not available for general use. Even the soil may contain plant food in abundance, yet it may be in such a state that the roots of the larger number of plants cannot use it.

Available plant food means food that is easily decomposed and soluble in water. The fine soil particles that contain the plant food ready for use are surrounded by a fine film of moisture that aids the rootlets in extracting the food. Therefore the presence of warmth, air, and moisture is essential to chemical and germ action. Plants use an enormous quantity of water, and a constant supply of moisture must be in the soil so that each soil 
particle can have moisture sufficient to dissolve the nutrial elements for the use of the plants. The home best fitted for the plant, therefore, consists of a deep soil thoroughly pulverized, containing a large amount of humus, and abounding in air and moisture. These are general principles of soil management that must be observed in cultivating cotton or any of the food-giving plants.

How the Plant draws Food from the Soil. The little germ inclosed so securely in the seed will break out, or sprout as we say, if the seed is exposed to water, heat, and air. As the seed absorbs moisture it swells. Then it puts forth the first root downward into the soil, and the stem starts upward to seek air and sunlight. The roots require moisture; the stem and leaves must have air and sunlight. Soon the plant consumes the little store of food that was deposited in the seed,.and it begins to creep around in the soil for more food. In order that the plant may thrive there must be a good deep seed bed containing food, moisture, and air in abundance.

If a cotton plant is pulled up one long central root will be seen, and from it grow many branch roots, and from each of these other branch roots. This branching continues until we discover very fine rootlets which are clothed with an innumerable number of fine hairs, hundreds and thousands of them branching out through the soil in every direction. They are out seeking food; but these roots are unable to take it in a solid state. It must 
all be dissolved in water. Some substances will dissolve quickly, some are more difficult of solution,

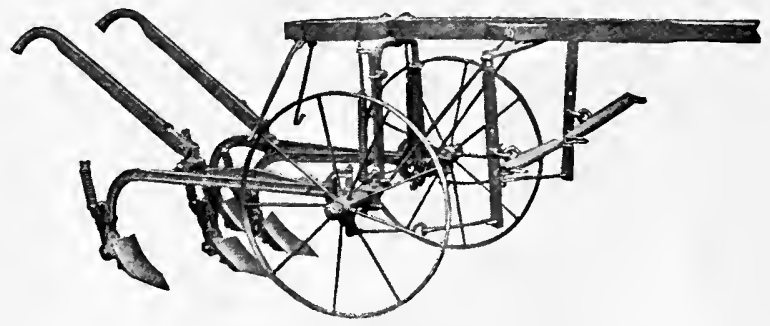

$\dot{A}$ walking cultivator.

Curtesy of 3. F. Arery \& Sons

and some are soluble in water alone. These rootlets, therefore, carry along with them a small amount of weak acids which they continually secrete as they go along, so that when the fine root hairs come in contact with the soil this weak acid dissolves small quantities of mineral matter that the water alone could not dissolve.

When the mineral matter is dissolved the roots draw it up into the plant and send it through the stem and limbs to the leaves. Here this water, which we call sap and which contains much food material, is converted by the leaves into available food for the use of the whole plant. This movement of the water from the roots to the leaves is called "the circulation of the sap." But there is a great deal more water than the plant assimilates. Large quantities are used by the leaf and then pass out into the air. Water therefore is continually passing from the soil through the stem, limbs, and leaves, and out into the air. The failure of crops 
is more frequently due to improper control of moisture than to any other cause. Too much water in the soil is as injurious as too little, since it excludes the air from the soil, so the cultivation of the land is largely for the purpose of controlling the water supply.

How Plants digest Food. The plants receive food from two sources: (I) from the soil, through the roots, stems, and limbs, and (2) from the air, through pores of the leaf. The leaf has many little openings, or mouths, chiefly on the under side. Through these it takes in the carbon dioxide of the air. The materials therefore from the soil and air meet in the leaf, where, by the action of sunlight and

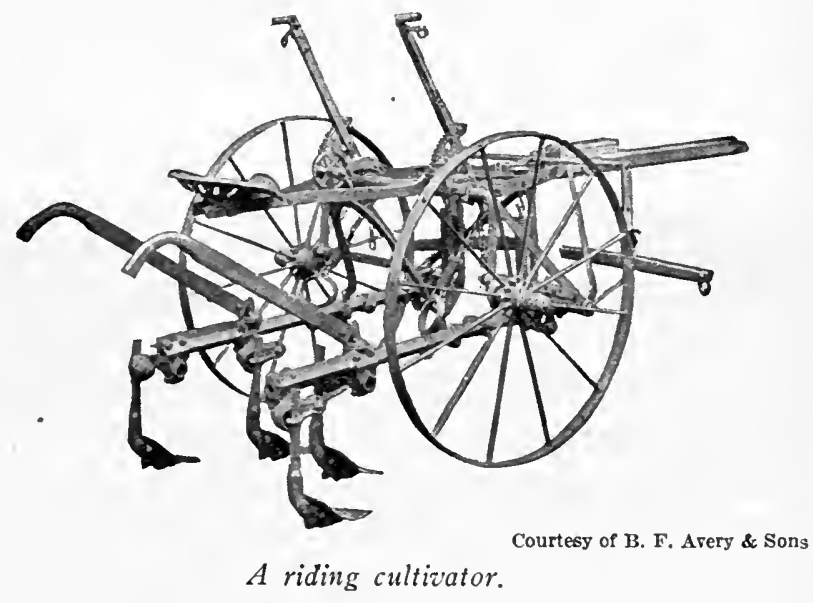

the green coloring matter found in nearly all leaves, this food material is digested for the use of the whole plant. 
It is the green leaf that prepares practically all the vegetable food for man and animals. The process has been compared to the milling of grain. The mill is the green part, the sun furnishes the motor power, the green substance called chlorophyll constitutes the machinery, and the soil water and

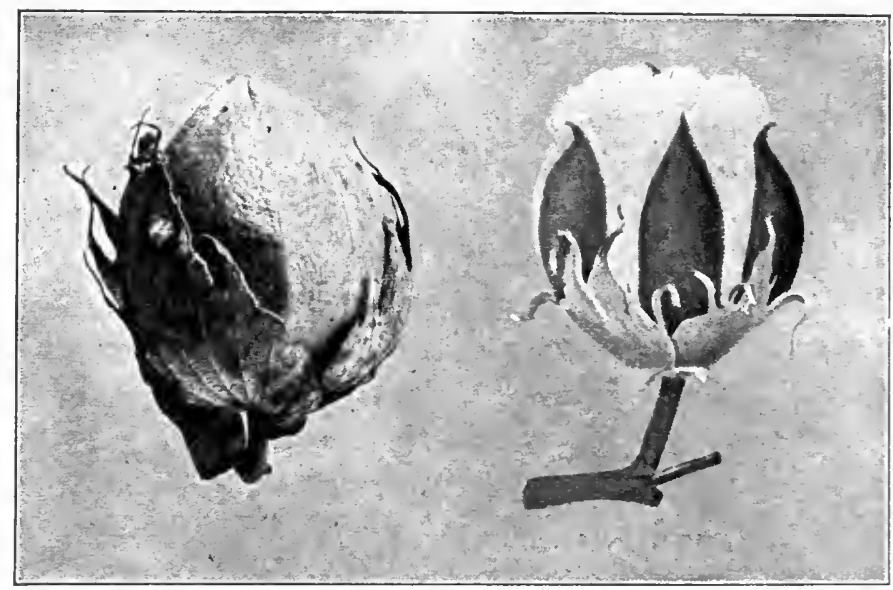

Courtesy of the Pan-American Union and of D. A. Tompkins $A$ matured cotton boll and a boll beginning to open.

carbon dioxide are the raw products taken into the mill.

We know that carbon dioxide is breathed into the air by all animals. Thus the animal kingdom furnishes food for the vegetable kingdom, and the vegetable kingdom takes the food from the animal kingdom, mixes it with the dissolved elements of the mineral kingdom, and converts both into food for man. Thus each kingdom is dependent upon the others for life. 
Habits of the Cotton Plant. The farmer prepares a deep seed bed of fine, friable soil, containing food ready for use as soon as the plant needs it. Beneath, in the subsoil, is a reservoir of moisture to be drawn upon by the plant as soon as the moisture of the seed bed is exhausted. The seed are planted in

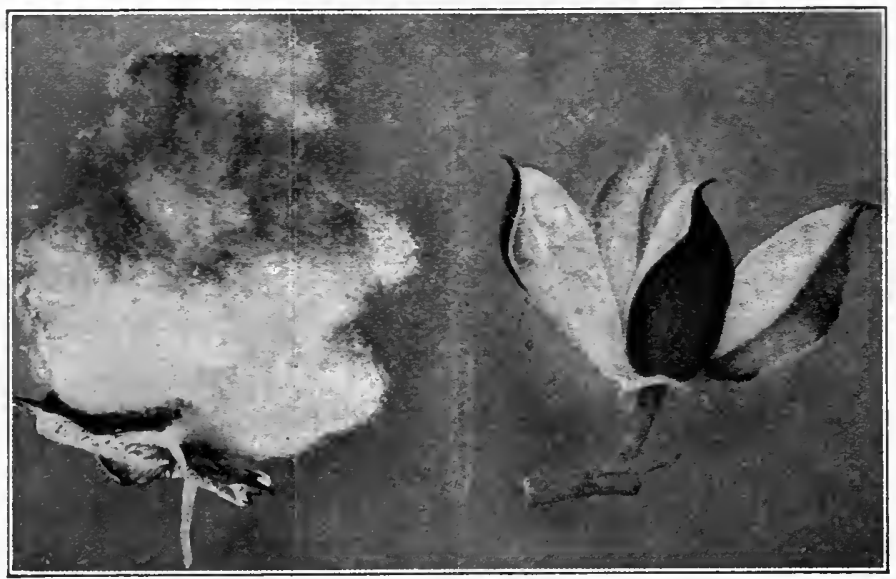

Courtesy of the Pan-American Union and of D. A. Tompkins $A$ cotton boll fully open and an empty boll.

early spring, the time varying from about the middle of March to the first of May, and germinate within three or four days, if the soil is well prepared and the temperature is favorable. When the plant grows well, buds are developed within a few weeks, and, on account of their shape, are called "squares." This is what the planter first looks for, because he has selected his seed with a view to producing the greatest number of "squares." A few weeks later, when the plant is from ten to fifteen inches high, 
the bud or "square" opens and produces a large rich, white flower about one and one-half inches long and about the same in diameter. The second morning the flower turns to a beautiful light pink color, owing to the effect of the sun's rays, and on the third day it deepens in color and, usually before the close of the day, falls to the ground, leaving a tiny boll. The appearance of this boll is what makes the farmer rejoice and become exceeding glad. It is at this point that the food supply begins to tell on the plant. Unfavorable climate, neglect in cultivation, impoverished soil, and an uncontrolled water supply will cause the "squares" or flowers to fall off, carrying with them the tiny bolls and the profits of the field.

The boll, after about a month's growth, matures from a bright green to a brown, and, becoming dry and hard, cracks open, separating into four or five segments within which are the seed and fiber that mean more to humanity than the entire gold and silver supply dug from the mines of all the continents of the world. Although the plants vary in height, the amount of cotton to each is determined more by the structure of the plant than by its height. It is sometimes not more than fifteen or twenty inches high, but generally from twenty-four to forty-eight inches. On the black prairie lands of Texas it is from three to six feet, and in the alluvial bottoms of the Mississippi, the Red, and the Brazos rivers it is from five to seven feet high. The size of the plant, the fruitage, and the value of the lint are 
determined by the soil, the climate, and the skill in cultivation.

Nature furnishes soil, climate, and moisture. What is then left for man to do? He can increase the food supply, control the water supply, and protect the plant against its natural enemies. With man and nature working together in harmony there is practically no limit to the possibilities of the soil, and wherever the cotton plant or any other cultivated plant proves to be unproductive it is due, in most instances, to the ignorance and indolence of man.

Increasing the Food Supply. The soil and the subsoil contain food in such quantities that it is practically impossible to exhaust the entire supply, for some plants require one kind and others another kind, and even the desired food, while it may exist in the soil, may not be available. Tillage, therefore, improves the physical condition of the soil and makes it easy for the roots to extend the area of their feeding ground. It hastens and augments chemical action by setting the plant food free. It aids in saving moisture by increasing the water-holding capacity of the soil. Therefore one of the cheapest and by far the most important methods of increasing the food supply of all plants is by deep and thorough plowing and by carefully harrowing the land in order to produce a well-pulverized soil.

A generation ago it was considered quite the thing to clean the land of all stalks, leaves, and 
grasses by burning all vegetable matter. It is now known that this vegetable matter, in addition to

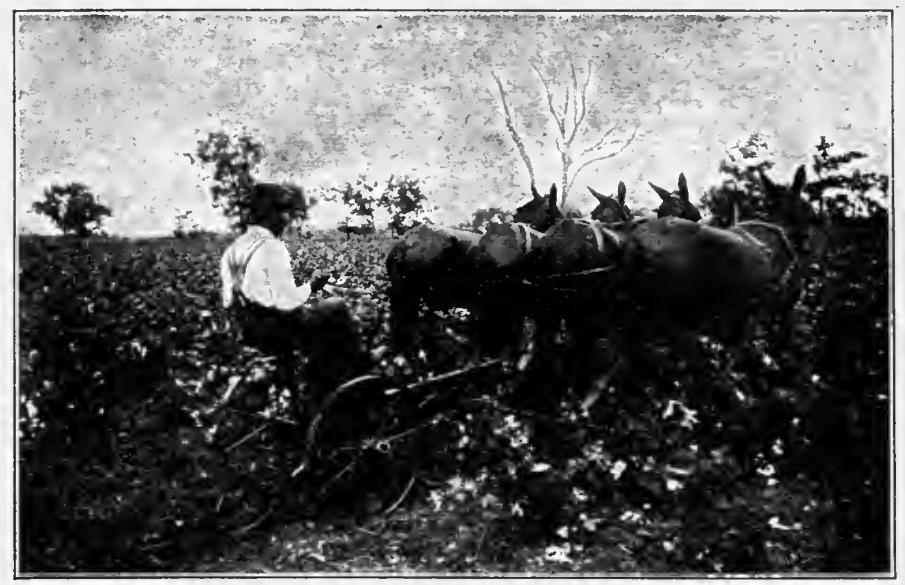

Courtesy of A. Clogenson, Dallas, Tex.

Cultivating the cotton field with a riding cultivator.

improving the texture of the land, contains a great supply of plant food. Returning this matter to the soil is nature's method of increasing the food supply, since it contains nitrogen, phosphoric acid, and potash, the three most valuable mineral elements for sustaining plant life, and whenever man through ignorance sets fire to his fields and lets the flames sweep the surface clean he is setting free the natural food of the soil to be carried away by the wind and rains. Therefore man has invented stalk cutters and harrows that will chop up this vegetable matter and turn it back to the soil to be dissolved again. For every one hundred pounds of lint cotton taken from the land nature leaves in the stalks 
about twenty-nine pounds of plant food in nitrogen, phosphoric acid, and potash to go back to the soil, and man has only recently learned that it is greatly to his profit to work the stalks back into the land. All vegetable matter that is not used for food by livestock should be returned to the soil for plant food.

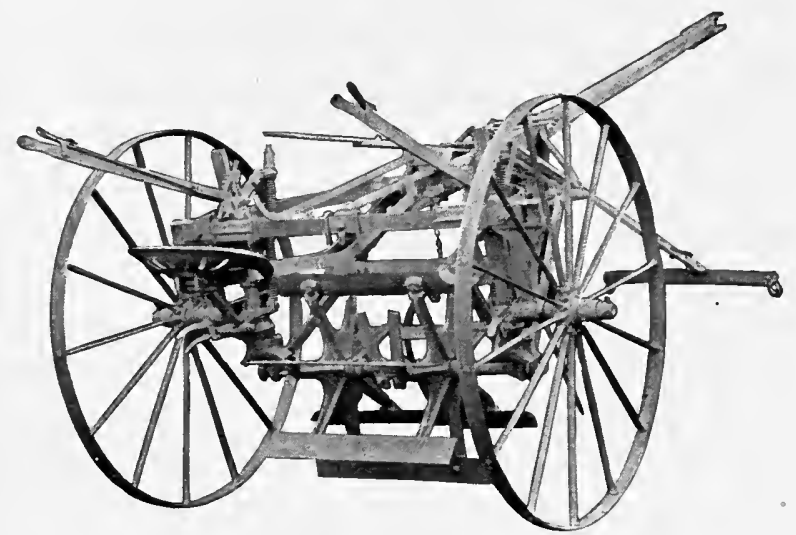

Courtesy of B. F. Avery \& Sons

$A$ cotton stalk cutter.

Soil is practically worthless without decayed vegetable matter, or humus. In addition to supplying food it aids the soil in controlling the moisture necessary for decomposing the food. Man has followed nature's lead therefore, and has learned to cultivate clover, grasses, and other vegetables in order that they may be turned back to the soil in the green state. This is called green-manuring. Some of these plants, such as clover and peas, draw nitrogen from the air, and leave it in the soil when 
the roots decay. These are called leguminous plants; and those which improve the texture of the soil and at the same time return the food elements are doubly valuable.

It was learned several generations ago that stable manure contained much plant food. If it is protected from the rain so that the food elements are not all dissolved and washed away before use, it is one of the most valuable sources of fertilizer, and saving farm manures is one of the most important problems of husbandry. The lack of intelligent care of this supply has frequently reduced its value to almost worthlessness. Leaves, straw, stalksin fact, all vegetable matter of the fields and of the forests, if properly prepared and rightly usedcontain plant food of great value and also help to improve the texture of the soil.

Commercial Fertilizers. The convenience of commercial fertilizers has caused farmers to neglect the home supply and in many instances to destroy that which nature provides for use. These fertilizers have proved of great value and are destined to play even a greater part in farm economy. But they are costly, and their exclusive use tends to hasten the depletion of the soil. Their effect is greatly increased by the use of green crops or farm manures.

The prime object in the use of commercial fertilizers is to increase production; and they must be used either to supply plant food directly or to act upon the soil so that a large quantity of its nutritive 
elements will be at the disposal of the plant. All the substances required by plants are abundant in the soil except nitrogen, phosphoric acid, and potash. Nitrogen promotes growth, for it enters largely into the composition of all plants and in the perfecting of its fruitage. Phosphoric acid promotes plant growth also, but it is essential to the perfection of the seed and in hastening the maturity of the crop. Potash is valuable for promoting fruitage. In the cultivation of cotton all these elements are necessary, and when they are not found in sufficient quantities in the soil they should be added. The soil may contain enough of one of these elements and not enough of the others. This must be determined by studying the growth and habits of the plant.

It is only within the present generation that the world has fully appreciated the value of the commercial fertilizers, and within the past fifteen years their consumption throughout the South has increased over fifty per cent and in some states more than two hundred per cent.

Phosphoric acid is obtained from ground bone and phosphate rock, though by far the greater supply comes from the latter. Phosphate rock is now mined practically in only three states,- - South Carolina, Florida, and Tennessee. The first discoveries of this important material were made in I837. near Charleston, South Carolina, on the Ashley River, but it was not until I 867 that experts learned how to obtain the acid from the rock and to prepare it 
for use as a fertilizer. The Florida deposits were first known in 1887, and the Tennessee deposits have been worked-since i893. Phosphate beds have been discovered also in Idaho, Utah, Wyoming, Arkansas, Pennsylvania, Alabama, Georgia, North Carolina, and Virginia.

Nitrogen, or ammonia as it is called commercially, is practically from two sources,- nitrate of soda, which is mined in Chile, and animal ammoniates, which come from the refuse of slaughter houses, city refuse, and fish.

Potash is mined almost exclusively in Germany. The imports from that country have more than doubled within the past ten years, and the trade relations between America and Germany make the manufacturers from time to time very uneasy as to the effect on the fertilizer business.

It is known that potash comes from beds closely related to salt beds. In the states of Texas, Oklahoma, Kansas, Colorado, and New Mexico there exist deposits of salt in such quantities as to cause experts to wonder whether potash beds may not be found; and the government experts are now investigating these fields.

Since all these elements are necessary to the production of cotton it is interesting to know that phosphoric acid, which forms about two thirds of the plant food in commercial fertilizer, is mined in the Southern States near the cotton fields and the center of the commercial fertilizer industry is to be found near Charleston, South Carolina. 
But the Florida deposits are considered the most valuable.

Controlling the Moisture. There may be an abundance of plant food in the land, but it is not available unless it is dissolved in water. Plants cannot grow without the presence of water. It prepares the food for the roots, maintains the life of the plant, and regulates the temperature. Soil that is in good condition for plant growth must have a good capacity for holding moisture. Humus in the soil is most valuable because of this capacity. It has already been said that the soil must be deep, loose, and friable, and that in order to prepare the food for the plants the fine particles of soil must be enveloped in a fine film of moisture which the roots use in dissolving the plant food. Humus retains the moisture for the use of the roots and soil particles. Without this the heat of the sun will evaporate the moisture, thereby reducing the food supply of the plants. New land is rich in humus. This is one reason why it gives so much better returns. Green manures or bone manures are valuable because of the humus.

The land therefore must be so prepared that the water will sink down through the soil rather than run away on the surface. It goes down into the subsoil, where it may be drawn up by capillary attraction by the humus in the soil when the supply begins to run low. Some soils produce healthy crops in dry weather while others are unable to keep up the life for the growing plant. Too much 
moisture is injurious, for roots of cotton and grain will not prosper in water. If the water level comes near the surface it must be remedied by proper drainage.

The Natural Enemies of the Cotton Plant. The greatest enemies of the cotton plant are ignorant landowners and ignorant laborers. These do more damage to the growing crop than all the insects, from the boll weevil to the army worm. Ignorance

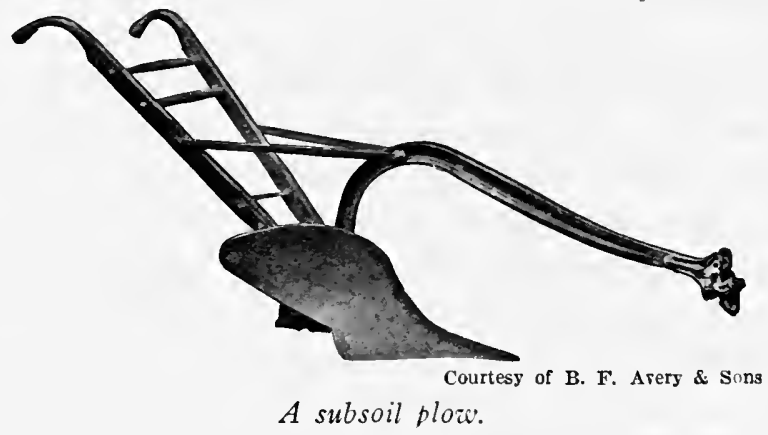

of the soil and the plant, lack of confidence in one's own power to make the soil obey the will of man, are the causes of famine, pestilence, and untold miseries. Ignorance affects one's own spiritua! welfare, makes politics a commercial enterprise, and gives one narrow and perverted views of the rights of man. It has been a too frequent notion that man shall be content in his ignorance, and beat the ground with his hands and trust to some mysterious power for his food and clothing. The cotton plant has more to fear therefore from ignorance than from all the other enemies combined. 
There are numerous insects that in one way or another feed on the cotton plant. The caterpillar, that attacks the cotton in the spring soon after the young plant comes up, and cuts the plant off near the surface of the ground, is one of these enemies. There are others that attack the leaf, feeding voraciously upon it and destroying it entirely. This becomes serious, for it is in the leaf that the food is digested for the plant. Other insects attack the stalk, and still others feed on the "squares," or bolls.

The two insects that feed on the leaves and the bolls are most dangerous. Those that feed on the leaves can be destroyed by spraying the leaves with a solution that is available for ready use. Machines have been constructed that will spray several rows of cotton at one time, but the best method used is to rotate the crops. This takes the cotton over to another field where this insect does not exist; and in the course of a year or two he dies for lack of food.

The Boll Weevil. The most serious enemy of all the insects is the boll weevil, because it feeds on the cotton boll, and there is no known method of completely destroying it. This enemy came from Mexico, and is sometimes known as the Mexican weevil.

In winter the weevil goes into winter quarters, and only a few survive for the spring, but the few that do survive feed upon the buds of the young plant until the squares appear. Here an egg is 
deposited, and the weevil develops to feed on the squares. Wherever frost or unfavorable weather causes the plant to cease putting on squares the weevil attacks the boll.

The insect multiplies rapidly. It is said that one pair will produce from June to November more

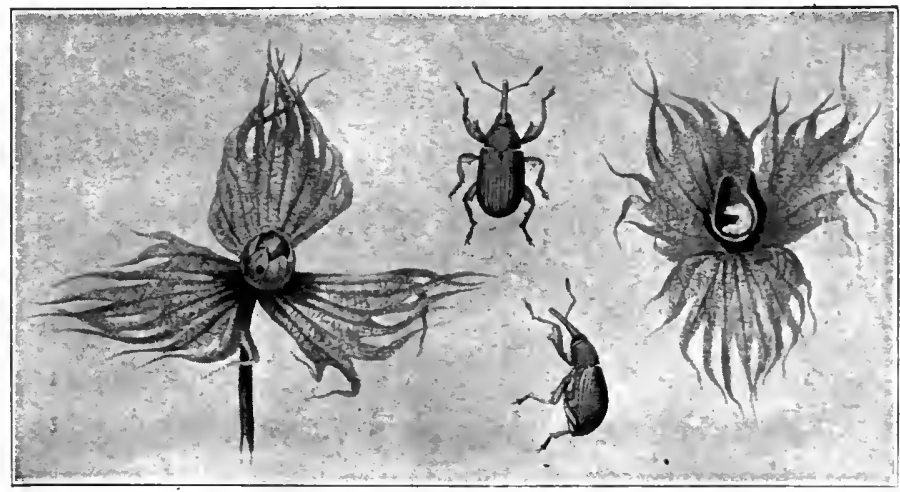

After Figs, 2, 4, and 5 in Farmers' Bulletin No. 344, U. S. Depart. of Agri.

Cotton square, about one half natural size, and boll weevil, about tarice the natural size. Square at left shou's egg puncture of boll weevil and flaring of bracts; square at right shows laria in position.

than twelve million weevils to prey upon the cotton plant. With the advent of cold weather the adult weevils begin to seek protection, and they fly from the fields in every direction, their movement being governed by the wind.

It is said that the weevil causes the loss of nearly a half million bales of cotton annually in Texas, Mississippi, and Louisiana, the three states where this plant enemy operates most. While this insect does do great damage, the fear and panic it has 


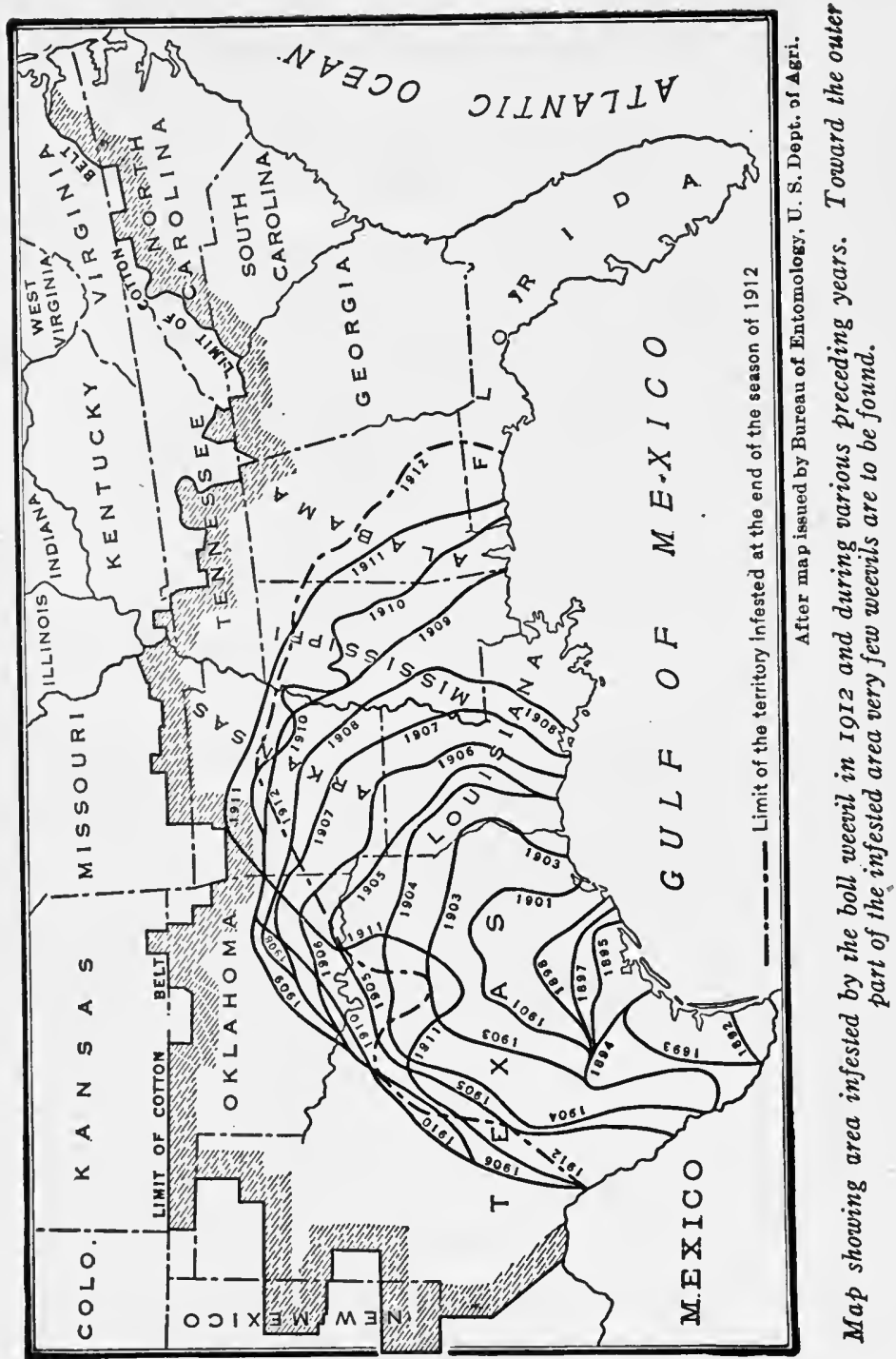


aroused among the inhabitants have caused much damage also, and many other evils are now charged up to this enemy. But from the boll weevil danger is great, and no completely successful means of destroying it have yet appeared.

After a careful study of the weevil it has been demonstrated that good cultivation of the land is the best means of destroying it. As a remedy it is recommended by the highest authorities that the land be well drained, the stalks in the infected area be destroyed before frost, the fields be broken as deep and as early as possible, early maturing seed be selected, planting be done as early as possible, and be followed by intensive and late cultivation, and the infected squares be knocked off and burned. 


\section{CHAPTER XVI}

\section{Different Varieties of Cotton}

Varieties of Cotton. We have seen in previous chapters that the cotton states produce about two thirds of the world's supply of cotton and that over six million bales are exported annually. Notwithstanding these facts the United States in I9Io consumed I 55,754 bales of foreign cotton. Even North Carolina, South Carolina, and Georgia, three of the leading cotton-producing states of the South, use every year a few thousand bales of foreign cotton. Therefore it appears that the American fiber is not suitable for certain uses and that different varieties of cotton are used in the manufacture of different grades of goods.

We have alrealy seen that the cotton plant is a native of the tropics, that it can be cultivated in the temperate zones, but that its habits change as the climate, soil, and cultivation change. In some places it grows as tall as trees; in others it produces two crops a year. Here and there it is found growing wild, with no cultivation whatever. Sometimes its fiber is fine and very white; again it is coarse and heavy like wool. Sometimes its color is a light yellow; again it presents a reddish or brownish tint which without dyes gives a rich color to cloth. 
What gives Value to Cotton. The value of the cotton fiber is determined not by the size of the plant or by the color of the lint, although the rich coloring sometimes increases its value, but by the length and fineness of the fiber. If we examine a handful of cotton by picking it to pieces and studying it carefully we see that it is made up of very fine, silky, hair-like strands or fibers. These fibers. are usually less than an inch long, but range from a half-inch to nearly two inches in length. If we hold the ends of two such fibers together and twist them in opposite directions they will cling together and make one long fiber; if we hold them side by side and twist them, they will readily unite in this manner and form a single strand. It is this quality that makes it possible to spin and weave cotton, and since the invention of the textile machinery has caused it to be used in more ways than any other fiber. Because of its wide use cotton is more valuable than any other fiber, and the longer and finer the fiber, the more valuable it is.

Principal Varieties of Cotton. The principal varieties of cotton vary in respect to the length and fineness of the fiber, which qualities depend upon soil, climate, atmospheric conditions, and method of cultivation. Since it is indigenous to the tropics and since it is cultivated north of the equator as far as the forty-fifth degree of latitude and south of the equator as far as the thirtieth degree, we naturally expect to find many varieties of cotton. We 
are not disappointed in our expectations, though only four varieties are recognized to be of any considerable economic importance. These varieties are the sea-island, the Egyptian, and what appears to be of the parent stocks of the Egyptian, the Peruvian, and the upland short staple. There are other varieties, however, such as the tree cotton of Mexico, the Brazilian and Indian variety, and many others of practically no importance commercially. All these different varieties may be divided into two general classes. The long-staple, which includes especially the sea-island, Egyptian, and Brazilian; and the short-staple variety, the most important of which is the upland cotton of the Southern States, and there are many varieties of each of these.

The following table shows the length of the fiber of various species;

VARIETY

Sea-island

Egyptian ...................52

Brazilian ...................3I

Indian $\ldots \ldots \ldots \ldots \ldots \ldots \ldots \ldots$..2I

Upland

. 1.06
LeNGTH OF Staple

$\begin{array}{cc}\begin{array}{c}\text { Minimum } \\ \text { in Inches }\end{array} & \begin{array}{c}\text { Average } \\ \text { in Inches }\end{array} \\ \text { I.4I } & \text { I.6I } \\ \mathrm{I} .30 & \mathrm{I} .3 \mathrm{I} \\ \mathrm{I} .03 & 1.17 \\ .95 & \mathrm{I} .08 \\ .8 \mathrm{I} & .93\end{array}$

Sea-island Cotton. On account of the length and fineness of its fiber sea-island cotton is the most valuable cotton grown in the world. It is its quality rather than its quantity that gives this variety its economic importance, for the total annual crop is only about one hundred thousand bales, usually 
less. Its fiber is so fine, however, that it is said one pound can be spun into a thread one hundred sixty miles long.

The original home of this species is thought to have been the West Indies. When it was first introduced into America, about $\mathrm{I} 786$, it was very un-

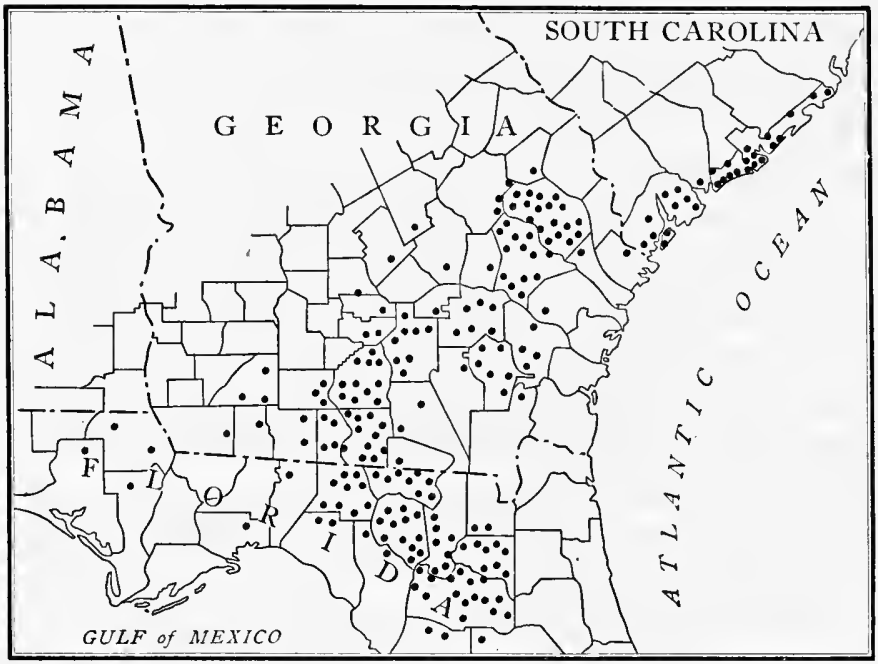

After Fig. 1, Farmers' Bul. No, 302, U. S. Dept. of Agri.

Where sea-island cotton is grown. Each dot stands for an az'erage production of 500 bales.

like the plant we know to-day. At that time it was a perennial. The plant was larger, matured later, and was less productive than now. This great change has been wrought by careful seed selection. For several generations the planters have selected seed from the earliest, most compact, and most productive of the plants having the largest and finest staple; and after a hundred years of this careful 
selection and cultivation the character of the plant has been radically changed.

The successful cultivation of sea-island cotton is confined to an area lying southeast of a line drawn from Georgetown, South Carolina, to a point in western Florida (see map, p. 332). The center of its production is on the Sea Islands, along the coast of South Carolina, and especially on the James, Edisto, John, and Wadmalaw islands. It is likewise produced on a wide area extending many miles inland, but the South Carolina variety is the most valuable. In 1909 it sold on an average at about thirty-three cents a pound, while the Georgia and Florida varieties sold for only about twenty-seven cents a pound.

The long, silky staple that has been developed by American skill is used for spinning fine fabrics and laces, and is of the greatest importance in the thread industry. The finer grades of spool cotton that are used in every home are made of this longstaple sea-island cotton.

Egyptian Cotton. Of the foreign cotton used by American manufacturers the largest amount comes from Egypt. The Egyptian cotton is of the sea-island variety, and although not so fine as that produced in America, it is better adapted than the upland cotton for use in manufacturing goods requiring a smooth finish and high luster. It gives to fabrics a soft appearance somewhat like silk.

Egypt is naturally adapted to the production of cotton. Its climate is favorable, since the warm 
season begins early, and the gathering of the crop is not interfered with by storms or rains. The

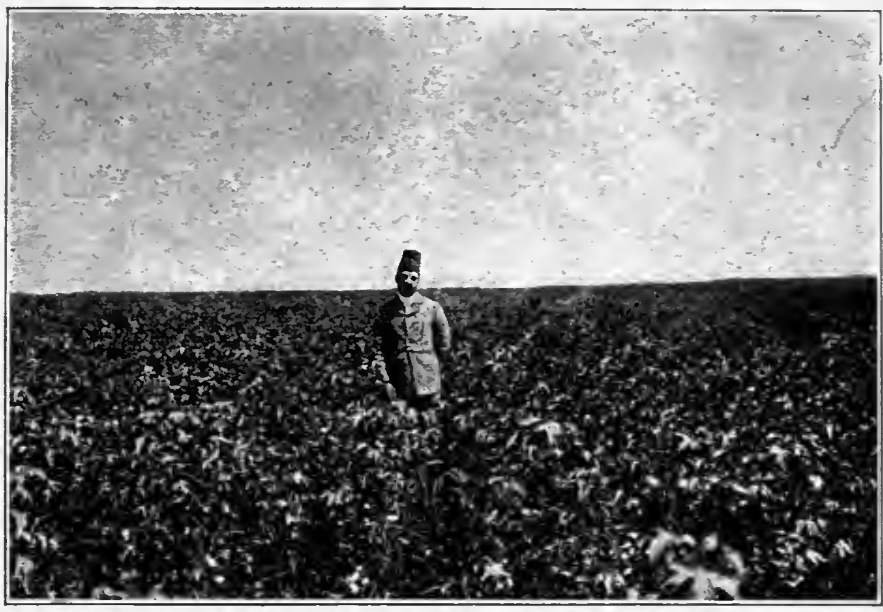

Courtesy of the Pan-American Union

A cotton field in Egypt. Egyptian cotton greatly resembles the sea-island cotton of America, and we import large quantities of it.

largest yield of Egyptian cotton was in 1906, when the total number of bales (five hundred pounds) reached one million four hundred thousand, which was about equal to the amount produced in the state of Mississippi.

From the fact that much energy is expended and expense is incurred in the importation of this cotton into America, and even into the Southern States, the interesting question is raised whether the United States cannot produce varieties of raw cotton equal to the demands of all her manufacturers. The value of the Egyptian cotton imported 
for the year ending August 3I, I9Io, was about eleven million five hundred thousand dollars, and manufacturers give four principal reasons for the use of this cotton in the United States: (I) It is well adapted to mercerizing and other processes that give a high finish to cloth and cause it to resemble silk; (2) its exceptional clearness and luster, as well as its capacity for taking dyes, fit it for mixing with silk and for filling sateen, India linens, and similar goods having a brilliant surface; (3) the brownish color of certain grades of the Egyptian cotton allows it to be used without dyeing in manufacturing such goods as balbriggan underwear and lace curtains in which the écru shade is desired; (4) it can be used for the manufacture of sewing thread and other articles which need to be very strong and for which no other type of cotton but sea-island has as yet proved suitable.

Frequent attempts have been made, therefore, to introduce this variety of cotton into America. The dry, arid lands of Arizona and southern California most resemble the climate of Egypt. In both places irrigation is resorted to in cultivation. The valley of the Salt River and of the Colorado River in Arizona and the Imperial Valley in California seem to be the places best adapted to this industry. While the efforts have not as yet proceeded beyond the experimental stage, they nevertheless indicate that the cultivation of this Egyptian cotton can be conducted profitably in these sections of the United States. 


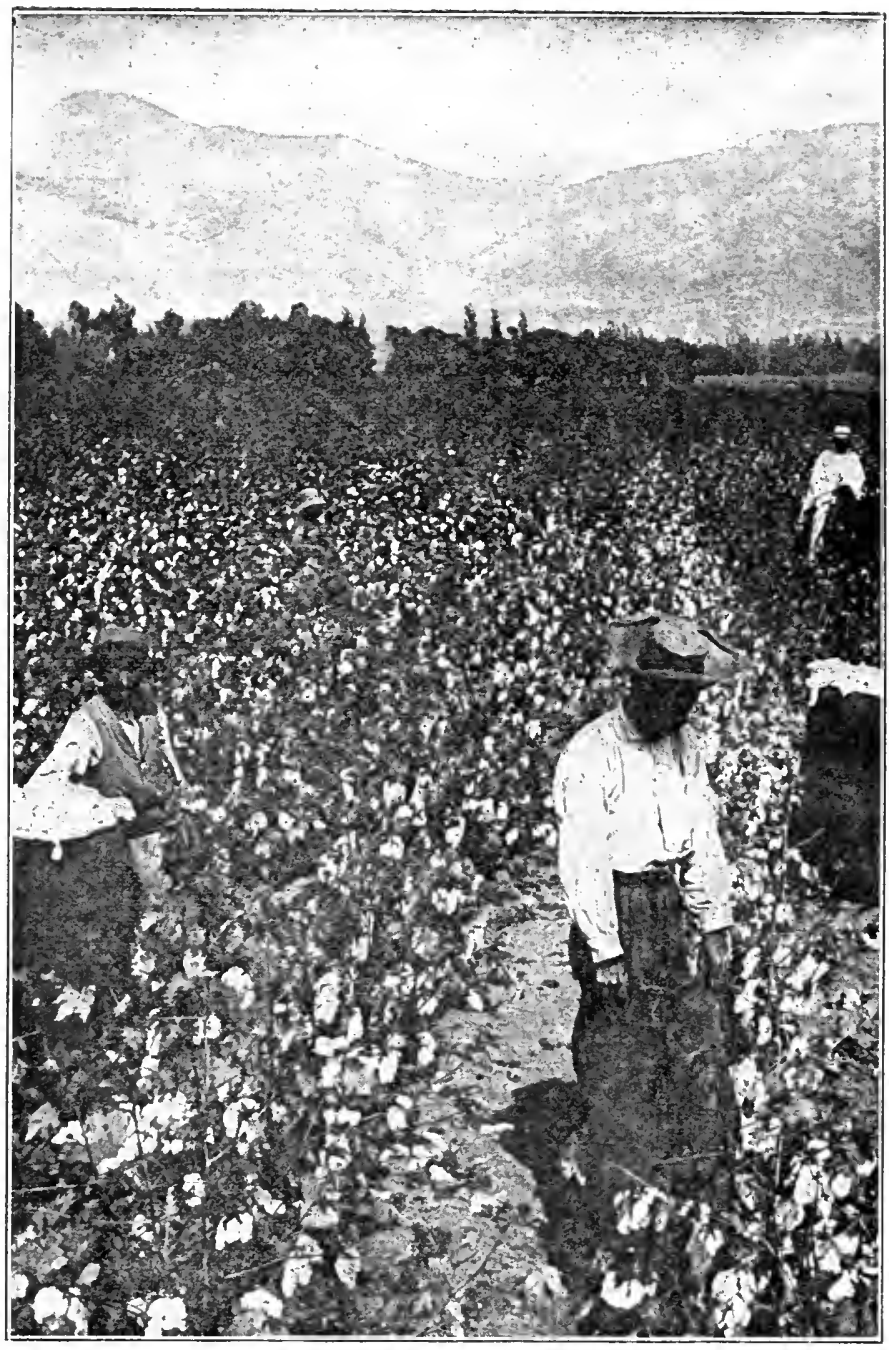

Copyright by Underwood \& Underwood, N. Y. Picking cotton in a Peru ficld. The result of irrigation. 
Peruvian Cotton. The next most valuable cotton in the manufacturing world is the Peruvian

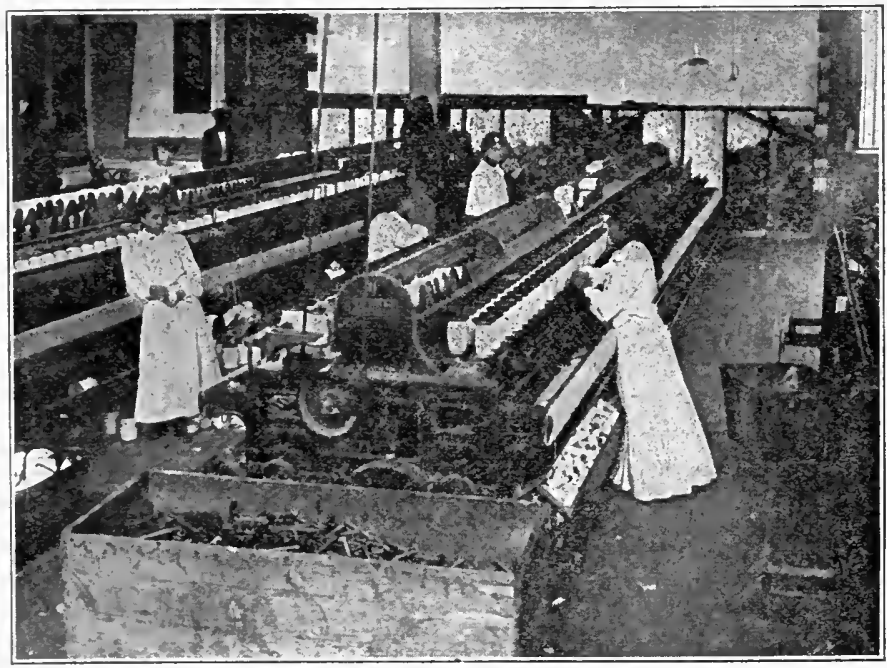

Copyright by Underwocd \& Uncientod, $\mathrm{Y}$. Y.

Interior of Inca cotton mills, Lima, Peru. Winding machines spooling cotton.

cotton. The inhabitants of Peru have been cultivating and using this fiber since prehistoric times. This peculiar variety has a rough, strong fiber and grows all the year round. The first crop is usually gathered in February, and under favorable conditions the plants will bear two crops a year for many years in succession without replanting. The ordinary productive period, however, is about seven years.

This variety of cotton is known in the commercial world as "Rough Peruvian." Its fiber is similar to that of wool, and its chief use is for mixing 
with or substituting for wool. It is of a reddish color and gives better luster and finish to woolen goods, hence it is frequently used in manufacturing underwear and hosiery. The United States imports about thirty thousand bales of Peruvian cotton annually. Efforts made to grow this cotton in the United States have been without success, largely because the climate here limits the growth to one year and does not permit the plant to develop during a number of years as it does when grown in South America.

The Tree Cotton in Mexico. The fiber of the Mexican cotton is of an inferior grade, but recently the tree cotton, called "caravonica," has attracted considerable attention. It was produced by the crossing of a fine long-stapled cotton with a coarse long-stapled Peruvian variety. This crossing, or hybridization, was conducted in Queensland, Australia, some ten years ago by an Italian scientist, and since then seed from the resulting plants have been planted in all parts of the world. Experiments are now being conducted with the fiber in Mexico, India, Egypt, and elsewhere. Those made in southern Mexico have been successful. A longstaple cotton has been produced in two varieties, "Wool Caravonica" and "Silk Caravonica." The first is coarse and mixes well with wool; the second is very long and silky and mixes well with silk. The tree or bush begins to bear from four to eight months after sowing, and will continue to yield from five to eight years without replanting. 
These four kinds of cotton are the most important of the class known as the long-staple cotton. It is known, however, that certain varieties of the long-staple cotton may be found growing here and there in countries that produce chiefly the shortstaple variety.

Cotton in India. Although cotton of the longstaple variety has been cultivated in India for fully

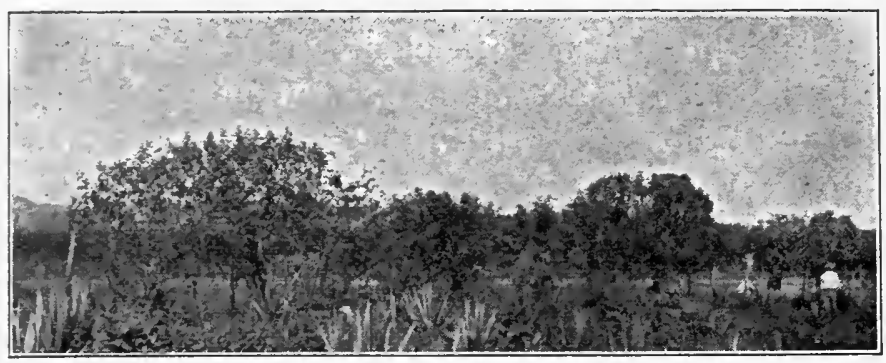

Courtesy of the Pan-American Unjon

The Mexican cotton tree. The fiber resembles that of the cotton of commerce.

four thousand years there was little effort to increase the production until from $x 86$ I to 1865 . During these years the cotton states of America, being engaged in war, were unable to supply the European mills with enough cotton. It will be recalled that the cotton famine was especially severe in England and France, and that those nations at the close of the year 1862 were approaching a crisis when India, stimulated by the high prices, increased her production and began shipping cotton in large quantities to England.

With a cotton area twice the size of the cotton 
states of America, India produces less than one third as much. The cotton factories in India use about one half of the cotton produced, and the other half is shipped largely to the factories of Europe, and especially to England. But some of it is used in America for mixing with upland American cotton.

It is an interesting fact that, while cotton has been cultivated in India for so many ages, it was not until the American plant was introduced into India that she became a rival of the cotton kingdom of the South. Now that same variety of cotton produced in another soil and in another climate is shipped back to America and mixed with American cotton. Although India has always produced large quantities of cotton, and made most beautiful and delicate fabrics from it, exporting these fabrics to all parts of the world, it is only within the past hundred years that she has exported any considerable amount of raw cotton, and this has been first grown from American seed. It was in 1854 that the first cotton factory was built in India, and to-day India has about half as many spindles as the Southern States of America and consumes about two thirds as much cotton.

For many years it has been the great desire of the English manufacturers for India to produce sufficient cotton to supply all the English mills. Railroads and good country roads have been built; a Department of Agriculture has been established; seed selection and scientific farming have 
been encouraged; a careful study of the soil by English experts has been conducted; and it is advertised that the soil of India, with proper cultivation, could produce ten million bales of cotton annually. The inhabitants of India; however, have not yet learned how to produce a food supply sufficient to protect themselves against famine, and until this is done the cotton monopoly of the Southern States will not be seriously affected by the cotton fields of India.

Upland Cotton. The cotton that is best known in the world, and that is produced chiefly in North Carolina, South Carolina, Georgia, Florida, Alabama, Mississippi, Louisiana, Texas, Oklahoma, Arkansas, and to a limited extent in Arizona, California, Kansas, Kentucky, Missouri, New Mexico, Utah, and Virginia, is the upland cotton. By referring to the table on page $33 \mathrm{I}$ it will be seen that this is of the shortest staple and the cheapest cotton produced. It comprises about two thirds of all the cotton of the world, and is used in a greater variety of ways than any of the other species.

It is probable that this cotton was brought into the South from the Barbadoes or the West Indies. It will be remembered that when it was first cultivated in Virginia and the Carolinas the inhabitants were puzzled to know what to do with it, since it lost all of its tropical habits when transplanted into a temperate climate and a different soil. Unlike all the tropical cottons then known to 
the world, it adhered so closely to the seed that it was difficult to separate the seed from the fiber, and not until Eli Whitney invented the cotton gin did the raising of cotton become a factor in the world's commerce, but since that date the influence on civilization of the short-staple cotton can hardly be estimated. The sudden rise of this commodity in importance is almost unparalleled in the history of economic products.

But cotton is a very peculiar plant. It responds readily to any difference in environment, soil, climate, good treatment, and fertilizers, and since it is easily modified in form and habit in a very few successive crops, cross breeding is not only common but usual. Many varieties which will produce a fine, long fiber in rich river-bottom soil soon lose these valuable qualities when grown on drier and poorer hill lands, or when the cultivation is poor and careless. In fact, no staple produced responds quite so quickly to intelligent treatment as the cotton plant.

Two hundred years ago the civilized people of the two Americas had hardly begun to look upon cotton as a product likely to be of much importance. With the natural tendency of the plant to vary, however, and with so many forces at work producing changes in form and habit, it is easy to see how varieties might have been multiplied indefinitely, even without deliberate action on the part of the cultivators. But as a matter of fact the Southern planter has for more than two hundred 
years been experimenting with this peculiar plant, and the hundreds of varieties in the South to-day are largely the result of these experiments.

Before the abolition of slavery the production of cotton depended on the activities of the slaves, who were unskilled, and such labor is never productive of the best results in any industry, and especially is this true in the production of the cotton, a plant which is sensitive to conditions and responsive to intelligent efforts for its improvement. Since the war, however, cotton production has been the subject of much study and experimentation, which has resulted in a great improvement in the plant, and a much larger production of the upland variety.

These are the leading varieties produced. Other sections of the globe, such as China, Manchuria, Chosen (Korea), Siam, Australia, West Coast of Africa, Spain, and Central America, produce the cotton plant, but the fiber is used locally and does not enter the world's commerce to any noticeable extent. The fiber in each of these countries shows such distinct variations that each might be classed as a different species.

How Different Varieties are reproduced. In every cotton-producing country there are slight variations from the prevailing type. Rich soil and poor soil on the same plantation will produce cotton that varies slightly; a plantation of the coast and one in the hilly country will produce slightly different varieties; and the tropical countries and the temperate countries also produce very different 
varieties. Soil, climate, fertilizer, heat, moisture, and the care of the plants all affect the growth and the product.

But the chief means employed by the planter for changing or improving the variety is careful seed selection. By this process he may develop early fruiting, rapid fruiting, and productiveness, and the methods of using it are easy and inexpensive.

Value of Seed Selection. No part of the process in cultivating cotton for the world's use has received more skillful attention than that of seed selection. It has come in with the development of farming interests, improved gins and presses, and with the development of the factory. The amount of cotton produced had to be increased, and seed selection proved to be one of the most efficient means of accomplishing that end.

In studying the nature of the plant it was observed that the plants that set fruit early had low fruit limbs. It was further observed that the plants that set fruit rapidly had short joints on the main stem or limbs. It was therefore easy to select seed from these plants and after a few years produce a variety that was earlier and fuller than the old variety.

The cotton plant was studied as an individual with reference to its special features. Those features which are economically important are the seed and lint, and the production of these in the greatest quantity is the chief desire of the planters. These products are affected by the size of the boll 
the size of the leaf, and the structure of the stalk as regards the length of joints. All of these fea-

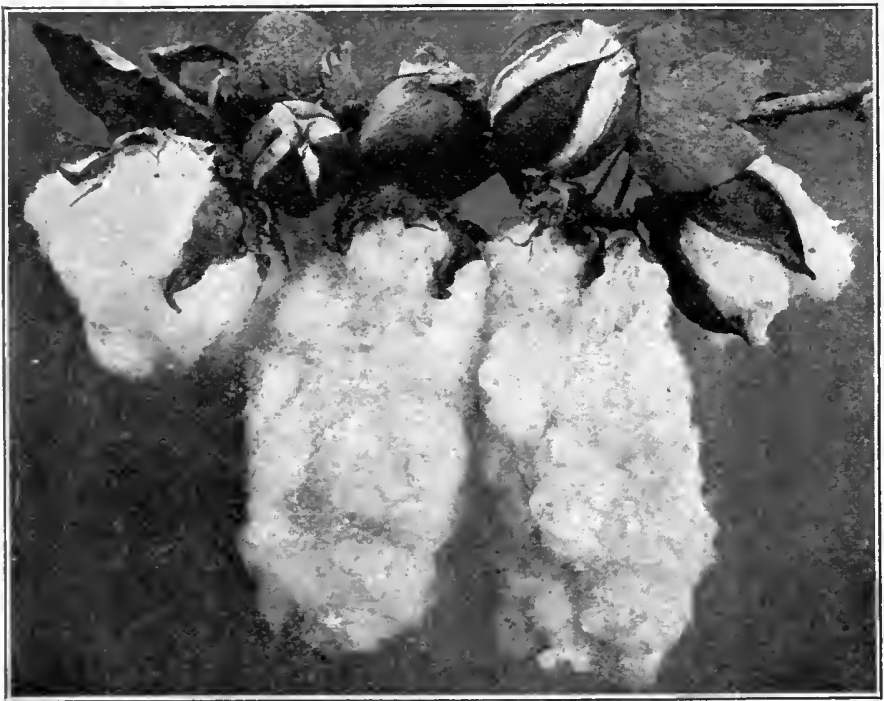

Copyright by J. Horace McFarland Company Long-fiber cotton. The result of skill in the selecting of seed.

tures vary in different plants of the same field, and all can be influenced in the right direction by seed selection.

How Seed are selected. The skillful planter studies his cotton as it comes to maturity, and observes that certain stalks here and there are loaded with the choicest bolls, while all around are stalks of magnificent growth but with few bolls. Some stalks contain as much as a pound of lint at maturity, and five hundred such stalks would make a bale of cotton. But only a few stalks as a rule are 
of this kind. After the plants reach maturity, the planter, going through his field, selects the best bolls from around the center of the short, strong, and vigorous plants, rejecting the bolls on the ends of the limbs. It is discovered that the fruit limbs of certain plants are short jointed, but the fruit extends to the outer border of the plants and are well fruited to the end. This is the plant that pays, and the farmer goes through his field, examining plant after plant, selecting those most valuable and picking the cotton from the matured bolls, always avoiding the plants, though very large, whose bolls are all too near the top, and those plants that are too small. In picking the cotton from which the seed are to be selected the planter avoids the bolls near the end of the limbs and those so low as to nearly touch the ground; for the top and the end bolls do not mature so well.

In a field of three or four acres, therefore, the planter may be able to select two or three hundred pounds of valuable seed cotton during a season. After it is carefully ginned, care is also taken not to mix the seed with any other of unknown quality. It is then stored in some dry place to wait for the planting. A good plot of ground, well fertilized, is now selected, and the seed are planted. By repeating the process for a few years, and by careful cultivation, the planter can produce a new variety that will yield from two to three bales to the acre. In the care and skill that is used in selecting the seed cotton useful knowledge of the nature 
of the plant is gained, and seed selection now takes its place by the side of improved machinery

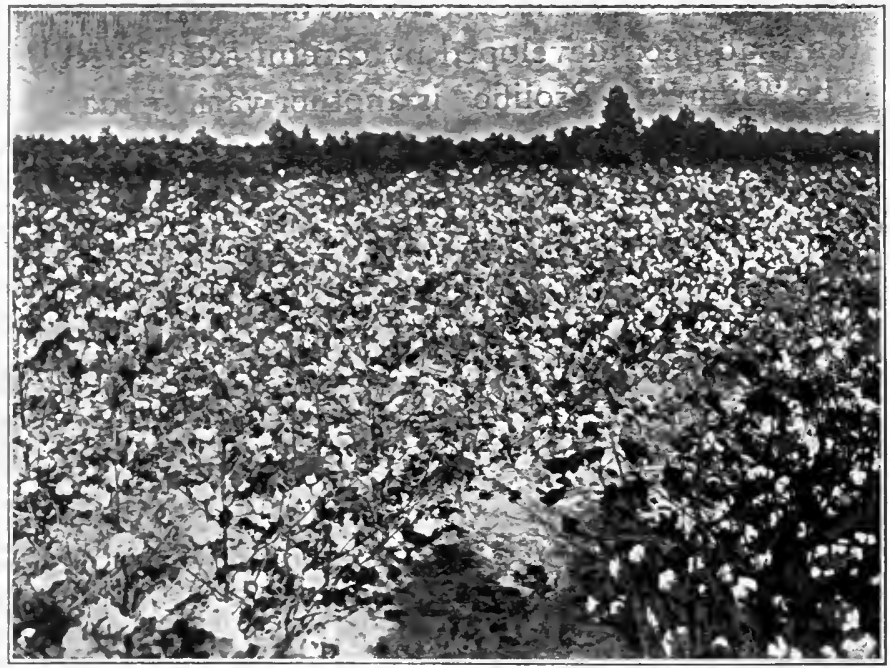

A field of "Simpkins Prolific" cotton. This variety yields more than three bales to an acre.

as one of the surest ways to increase the yield of cotton and to reduce the amount of labor used in its production.

Nature taught the first cotton planters in the South that much depended upon the seed; and for a hundred years there have been intellectual planters who have made repeated efforts by seed selection to improve the plant. In $18 \mathrm{I} 6$ one, Walter Burling, introduced a new variety which came from seed brought from Mexico. Two years later we find another variety in use in the Carolinas called the "Hollingshead." The demand for more cotton 
created a demand for a better variety, and one that would yield more to the acre, and by 1860 there were to be found in every state dozens of varieties that had been developed by careful seed selection. The "Simpkins Prolific" is another variety that has recently been developed in Wake County, North Carolina. W. A. Simpkins, who developed this well-known variety, began in 1898 to use skill in selecting his seed. He first purchased the best seed known. When the plants began to mature he gave the field his most careful attention, keeping watch for the finest and earliest stalks to mature. He observed that two plants fruited and matured two weeks earlier than the others. The seed from these were picked by hand and formed the basis for further development of the seed that are now being cultivated in every section of the South. He is now able to produce more than three bales to the acre as a result of his skill.

Cross Breeding to improve the Variety. It is frequently desirable to combine the good qualities of one plant with those of another, and in the combination to produce a better variety. This can be done by cross breeding or, as it is called, "cross fertilization." It is quite probable that this is the method nature adopts in producing new varieties. Crossing one plant with another is accomplished by simply transferring pollen of the flower of one plant to the receptive stigma of the flower of another plant after having first removed the pollen of the latter. The flower is then covered to prevent 
fertilization from other sources. This method, while used by experiment stations, is not used much in improving the variety of upland cotton where the desire is merely to secure early and rapid fruiting and productiveness. These properties can be secured by proper seed selection.

Cotton of the South in Relation to the Vivorld's Supply. The world's annual production of cotton is between eighteen and twenty million bales. About two or three million bales, it is estimated, are userl in the home without ever reaching the factory or the commerce of the world. Hence there is no way of telling accurately the total amount of cotton produced. There has been a careful estimate made, however, of all cotton that is sold for manufacturing purposes, and the following table shows the production by countries in 1908, when the largest yield was reached:

Place of Production

No. Bales

The total of the world ................... I9,6r3,000

United States ......................... 13,002,000

British India . . . . . . . . . . . . . . . . . . . . . . . . . . . . . . . . . . .

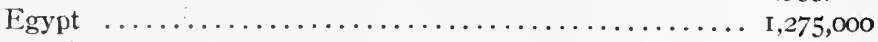

Russia ............................ 846,000

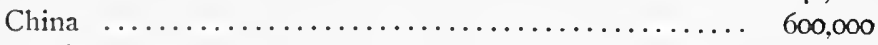

Brazil ............................... 425,000

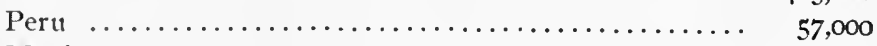

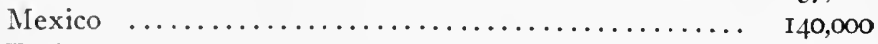

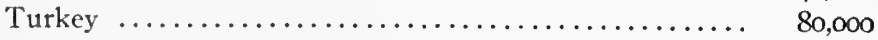

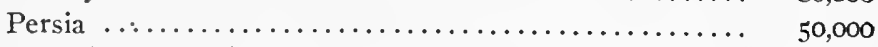

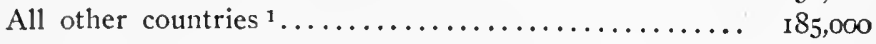

1 Grecce, Italy, Indo-China, West Coast of Africa, Dutch East Indies, Japan, Korea, Haiti, Argentina, Australia, the Philippines, and in small quantities in other tropical or semi-tropical countries. 
In 1862 , when the Southern ports were blockaded, the high price of cotton had a wonderful effect in increasing the production in India, China, and other Eastern countries, for they supplied the European mills, and the South for the time lost her influence in the world's markets. The only reason the South to-day holds the monopoly is because she can produce and market more cotton with less expense than India or the other cottonproducing countries, and if the time ever comes when India, by scientific farming and by industrial improvements, can produce ten million bales, the South will lose her monopoly unless her sciertific farming and her industrial improvements increase accordingly and make it possible for her to produce a better grade of cotton in larger quantities, and thus undersell the other countries of the world. The cotton states hold the same position in cotton production that England holds in cotton manufacture, and this position can be maintained only by increasing the skill and efficiency of the cotton producers.

Every country has entered the world's commerce. It is confined neither to races, religions, nor nations. The yellow race of China and Japan, the brown race of India and Africa, the dark-skinned Caucasian of southern Europe, South America, and Mexico, and the light-skinned Caucasian of North America and northern Europe-are ali competing for supremacy in the world's commerce; and especially in the commerce of cotton. The Southern 
States of America hold this supremacy to-day, but if it is maintained in the face of all this competition it will be by virtue of superior skill. 


\section{CHAPTER XVII}

\section{The By-Products of Cotton}

Result of Harmony between Man and Nature. The history of the cotton industry illustrates this principle, that enlightenment of mankind is increased by inventions and discoveries which in turn create new industrial problems that call for still other inventions and discoveries. Thus man is ever modifying or changing his environment, while the environment is ever modifying or changing the habits of man. The intelligence of man and the forces of nature are acting and reacting on each other, whiie the race is working upward, always passing into a higher and clearer intellectual zone, where many phenomena, once mysterious, are made plain, and new forces are brought into service for the advancement of the race. Moreover, as the arts of life have unfolded, man has become more open minded to natural causes. He has learned to adjust himself more readily to the forces of the world, to work in harmony with them, and to adopt for his own uses many things in the natural world which were once thought to be useless or harmful. The world, therefore, has practically been made over in the last hundred years. New sciences have been evolved that have given a new meaning to life. 
New occupations have been opened up, making it easier for men of different talents to provide an honest living. New subjects have been added from time to time to our school curriculum, until to-day the whole purpose of education has undergone a complete cliange. New foods for man, beast, and plant have been discovered, and ancient food plants have been so influenced, and their habits have been so changed, that they bring forth a hundredfold more to-day than they did in their original state. These are some of the results of man and nature working together in harmony.

How Ignorant Man considered the Cotton Seed. Man's ignorance of nature and the results on himself are best illustrated by the uses made of cotton seed more than a century ago. The seed were thought to be poisonous, since hogs ate them and died. In order to protect the hogs, therefore, the seed were inclosed in pens, and both cattle and hogs were carefully guarded to see that they did not.feed on them. A.t that time, of course, the seed were a nuisance, and in order to be rid of them the planters would dump them into creeks or swamps where the cattle and hogs could not find them. But the odor arising from them in a decayed condition generated a miasmic stench which was not only very offensive, but was thought to produce malaria and other diseases. Since the seed, therefore, were supposed to cause sickness and death, they were the natural eneny of man and beast.

The seed constitute about two thirds of the 
weight of the cotton as it is picked from the fields. A planter producing many bales would have, therefore, a large quantity of seed to dispose of. Since they were poisonous to man and beast, something had to be done with them. It was demonstrated clearly, moreover, that land where piles of seed had remained for some time refused to bring forth any plants at all. Therefore the seed were poisonous also to plants, and how to dispose of them was really a problem; and many planters piled them in great heaps and burned them. But it was really seriously considered at one time that it would be better, after all, to discontinue the production of cotton, since the seed were injurious to man, beast, and plant.

The First Uses made of Cotton Seed. It was discovered that seed might be covered early in deep furrows, and by thoroughly decaying before planting time they would add some plant food to the land. It was also discovered that seed might be boiled with other foodstuff and fed to cows without injury. But it was claimed that the butter made from cows eating that food was not nutritious.

The cotton growers of Asia, however, had discovered long before that it was the oil in the seed that was injurious to cattle. Therefore they ground the seed in crude mills, pressed out the oil, and fed the cake to their oxen. The oil was used for illuminating purposes. It will be remembered that it was in Asia that the cotton fiber was first used 
for making clothing, and it is interesting to know that it was on that same continent that the seed were first used for food and the oil found of commercial value. It was in England that the modern factory first appeared for using the cotton fiber produced in America; and it was in that same country, the year after the close of our Revolu-

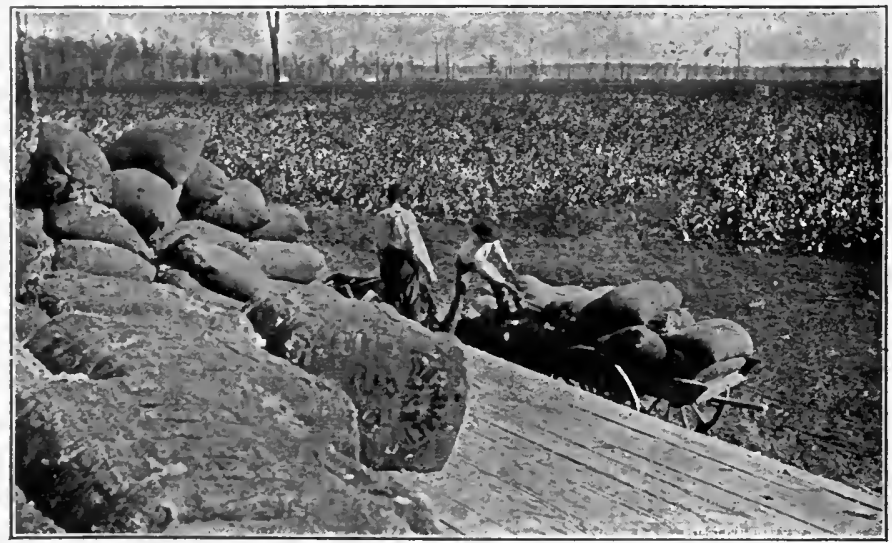

Copyright by the Detroit Publishing Co. A familiar scene in the cotton country. Hauling cotton seed, bound for the oil mills, to the railzay station.

tionary War, that the oil and the meal made from the seed shipped from America first attracted the attention of the Western world. Thus a new food for cattle was finally discovered to exist in the cotton seed of the Southern States.

The meal could be used for cattle food, and any wholesome food soon finds a ready market value. Therefore a demand was created in England for the cotton seed of the South, and in 1826 a cotton 
mill was erected in Columbia, South Carolina. In I 832 one was operated on one of the islands of the coast of Georgia. Thus was begun a new industry in the South. But the meal from these mills was shipped to England and used there for cattle food.

About that time it was learned in the South that the French had been for a number of years importing from Egypt cotton seed from which they extracted the oil, and after refining it, used it for edible purposes. Thus it was discovered that the cotton seed of the South contained food for man. Paul Aldige of New Orleans visited Marseilles for the purpose of studying the processes of extracting and refining oil. On his return home the cottonseed industry was begun in New Orleans. However, attempts had been made as early as 1847 to manufacture oil from cotton seed, but the venture met with little or no success. In I860 there were seven oil mills in the country, but the Civil War caused a practical suspension of this business. However, in 1870 there were twenty-six establishments in the United States. But to-day, wherever cotton is grown, there are mills of various sizes converting raw seed into oil, meal, hulls, and linters, every part of which is valuable and finds a ready sale in the markets of the world.

Products of the Cotton Seed: Linters. When the first mills were established it was learned that the short, fine lint that adhered to the seed was injurious to the oil, so an improved gin was brought into use at the mills that would remove this lint. 
This product is called "linters," and only about a generation ago it was thrown away as useless material. To-day it enters into many lines of manufacture, where otherwise it would be necessary to use a better grade of cotton. It is used especially in making low-grade yarns. wrapping twine, cheap rope, and lampwicks. It is used also in manufacturing mattresses, comforters, cushion pads, and in upholstering. Again it is used for mixing with wooi in making wool hats, and finally it is used for making writing paper and in the manufacture of gun cotton and niter powder. Linter cotton, therefore, is an important factor in the total cotton supply, and 296,640 bales were taken from the seed in 1909, after they were shipped to the oil mills. A little more than a generation ago this amount of cotton would have been thrown away.

The Hulls. After the seed have been ginned the next process is to run them through a machine which cuts the hulls away, leaving as far as possible the meat or kernel undisturbed. In the earlier days of the cottonseed-oil industry these hulls were supposed to be injurious to cattle. Therefore the cattle were guarded carefully to be certain that they did not eat the hulls, which were burned in the furnaces for fue!. But the quantity of hulls exceeded the demand for fuel. As they accumulated it became a problem to know what to do with them, and it was not until 1890 that their value as a cattle food was fully realized. Since then the demand for them has extended all over the Southern and 
Western states. They are now packed in bales about two feet square, weighing about a hundred pounds to the bale, and sold as a cheap and effective substitute for hay. The business has so developed in recent years that, it is estimated, probably five hundred thousand cattle, besides a large number of sheep, are fattened on the hulls of the cotton seed.

Cottonseed Meal. After the hulls have been removed the kernels are then passed through the crusher and many other processes. The oil is then pressed out, leaving a hard, dry cake, which is ground up into a fine meal and put into sacks of about a hundred pounds each. Sometimes the meal is bolted like flour in order to take out all the impurities. It is then especialiy valuable as a food for cattle and as a fertilizer for cotton and other plants. As a food it is very important. Among all the feeding stuff for animals it is richest in protein, the most valuable and costly ingredient of all foods. It even ranks higher than wheat or corn. Large shipments of meal and hulls are made to the West and Northwest, and thousands of carloads of cattle in the South, fattened on these foods, are sold to the stockyards of the Northwest.

At first the Southern States used only a small amount of meal as a food, the rest of it going to the Eastern and Northwestern states and to England. Its value as a food, however, has gradually increased until it is universally esteemed, and large quantities are used annually. It is claimed that the 
meal fed to cattle will furnish sufficient nourishment for them and produce at the same time about ninety per cent of its own weight in stable manure. It appears, therefore, that cattle act as a sort of fertilizer factory by taking the meal and changing certain elements of it into beef and butter, and other elements into stable manure.

It will be remembered that the Southern planters once thought the seed were injurious to plants when they were in the green state. But with the oil removed, the meal is now recognized as one of the cheapest sources of nitrogen, which is the most costly and valuable element of fertilizer. In 1876 a certain inspector of fertilizer refused, in his ignorance, to certify that a certain fertilizer was standard because it contained cottonseed meal. This is another evidence of the costliness of ignorance. However, it is generally used to-day by all manufacturers of fertilizers.

A few years ago the United States Secretary of Agriculture was asked whether the farm lands of the South could be made as productive as the rich lands of the Northwest, which sell for one hundred fifty dollars an acre. He said: "Why, of course. What is the hindrance? But the Southern farmer must quit sending his cottonseed meal over the world to enrich other lands. He must use the rich fertilizer himself."

So valuable is the meal that it may be substituted for nitrogen and potash, and by mixing cottonseed meal in right proportions with acid phosphate a 
valuable fertilizer is produced, all of which come from the cotton fields and the mines near the fields.

Cottonseed Oil. The most valuable part of the seed, commercially, is the oil. It is known to-day that the oil was the injurious element of the seed when they were considered harmful to man, beast, and plant. For many centuries oriental people and inhabitants of southern Europe have valued highly the oil extracted from various plants. The fats of animals have never been regarded by these people with the same degree of importance. In fact, the religion of many oriental people prohibited the use of fats and meats of certain animals. Therefore they learned years ago to extract edible oils from certain plants, and of these olive oil is the most famous and has an ancient history.

Certain manufacturers in southern Europe discovered in the early part of the past century that cottonseed oil was very similar to olive oil, that when it was refined it could be substituted for olive oil, and that the inhabitants of southern Europe and eastern Asia, who ate large quantities of olive oil, were unable to tell the difference between it and refined cottonseed oil. Thus it was discovered that the once harmful cotton seed which caused the Southern planter to consider discontinuing the production of cotton, because the seed killed hogs, cattle, and plants, and brought disease to man, is one of the most valuable parts of the cotton plant, since it brings food to man, beast, and plant, and is in no wise harmful when it is used properly. 
Therefore things ignorantly destroyed in one generation may become valuable articles of necessity in the next, and the world keeps advancing.

It has already.been told how Paul Aldige of Louisiana learned from the French manufacturers how to refine the oil extracted from the cotton seed, thus making it an edible commodity. This was the

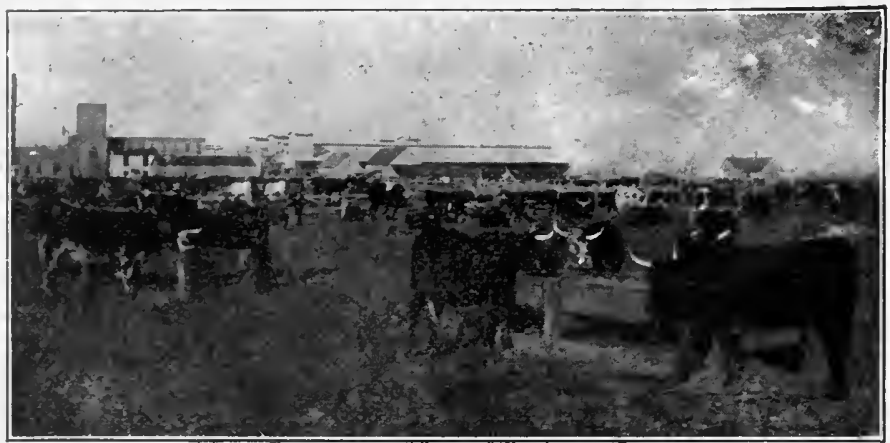

A cottonseed-oil mill in Arkansas. Note the cattle being fed on meal and hulls.

beginning of the cottonseed-oil industry of the South.

The oil that comes from the seed is first called crude oil. In this state it is of little value; but when it is refined it is called "summer yellow," which has a very high commercial value. This grade is shipped to Italy, where the inhabitants use large quantities of olive oil, and here it is treated over again and used by the inhabitants as olive oil. For a long time the olive oil shipped from Italy to America was nothing more than cottonseed oil treated by the Italians and shipped back to 
America, and for a number of years this country was unable to tell the difference.

The highest grade of "summer yellow" is worked over and put through certain processes which give us oleomargarine, butterine, lard under the name of cottolene, and salad oil. A very large part of the oil produced in America is shipped to Europe, the principal part going to Holland for making artificial butter; and the finest grade of oil known is butter oil. Large quantities of the inferior grade are shipped to France, where it is converted into soap.

In addition to the above uses, the oil is employed in packing sardines and similar fish; it is a substitute for linseed oil in painting; it is used by miners to supply fuel for their lamps; it is used by druggists in the manufacture of medicine; it is used frequently as a substitute for bacon and lard; and in many instances to-day the laborers at the mills, instead of being afraid of the oil as they once were, no longer bring meat for their dinner but, it is said, "put their bread under the presses where the sweet, warm, fresh oil is trickling out, and eat it with a relish, finding it healthful and nutritious."

It requires on an average fifteen hundred pounds of cotton seed to produce a five-hundred-pound bale of lint cotton. Therefore the seed taken from a bale of cotton weigh about a thousand pounds. When these are run through the mill and separated into linters, hull, oil, and meal we have the following commodities and their commercial value: 
Commodity

LBS.

PrICE

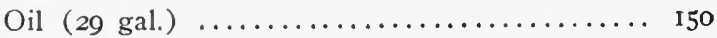

$\$ 8.60$

Meal ....................... 337

4.50

Hulls

500

2.10

Linters

13

.45

Total

1,000

$\$ 15.65$

Practically every cotton planter in the South remembers the time when cotton seed were piled high in the fields and were considered almost a useless product. But to-day the seed from a bale of cotton will sell at the mills for about fourteen dollars; and by the use of machinery the manufacturer is able to separate them into different commodities and sell them at a small profit.

Growth of the Cottonseed-oil Industry. When some genius discovers a great value in a waste product it is easy for the world to adopt it, and when new values were discovered in the cotton seed the world at once began calling for them. Since the South is the great cotton section of the world it is natural that she should profit most by these discoveries, and we have no greater evidence of their value to her than the rapid development of the oil mills since I860, as the following figures show:

\begin{tabular}{|c|c|c|c|}
\hline YeAR & No. of Plants & Cafital & VALUE \\
\hline I 860 & $\ldots 7$ & 351,000 & 741,000 \\
\hline 1880 & $\ldots \ldots \ldots \ldots \ldots 45$ & $3,862,500$ & $7,690,000$ \\
\hline 1900 & ...............295 & $35,000,000$ & $42,410,000$ \\
\hline I9IO & $\ldots \ldots \ldots \ldots \ldots \ldots . . .640$ & $96,200,000$ & $*_{140,120,000}$ \\
\hline
\end{tabular}

Between 1860 and I900 the industry was in the *Estimated. 
experimental stage. The exhausted condition of the soil in the South Atlantic States led to the use of seed as a fertilizer. They were composted with stable manure, muck, or woods mold, and used with some profit, but the commercial value was small, since they sold for only six dollars or nine dollars a ton. The seed from one bale of cotton brought in the markets of the South only from three dollars to five dollars. It was not until about I900 that the real value of the cotton seed was understood, and during the period of forty years, from 1860 to 1900 , chemists and manufacturers were experimenting with the elements found in the seed and learning the various uses of each.

Experiments are still being made, however, and other uses in all probability will be discorered. Cottonseed flour for human consumption was manufactured for the first time in 1909. The process of making it is rather expensive, so it cannot yet be put on the market as a cheap product. The flour is so rich that it must be mixed with wheat flour or corn meal, and when mixed in this manner it makes a bread that is decidedly wholesome.

Scores of experts, chemists, and experimenters are at work in their efforts to extend the uses of the cotton-seed products, and the results obtained within the past ten years are wonderful. It is declared that new kinds of oil will be found in the seed for the use of housekeepers; and since vegetable oils, as a rule, are more wholesome than animal oils, fats, or lards, the more refined cotton- 
seed oil will find even yet a more prominent place in the home in the form of cooking fats, salad oils, or butter.

The Commercial Value of the Cotton Seed. The South produced I0,3 I 5,382 bales of cotton in I909, and the seed from such a crop amounted to about 5, I50,000 tons. The average market value was twenty-seven dollars and seventy cents a ton. So the cotton seed alone produced in the South in 1909 was worth one hundred forty-two million dollars. However, only about sixty per cent of the seed produced were sold to the cotton mills. But the value of this sixty per cent is shown in the following table:

Products

QunNtrty

Value

Cotton seed manufactured... 3,269,000 tons,

Oil extracted ........... I31,000,000 gallons

Cake and meal.......... 1,326,000 tons

Hulls ............... I,I 89,000 tons

Linters ............. 296,640 bales

per ton, $\$ 27.70$

$\$ 55,230,000$

$35,910,000$

9,8ro,000

$4,770,000$

$\$ 105,720,000$

These figures show how much wealth has been added to the cotton kingdom by a scientific study of one of its most valuable products, which a halfcentury ago was considered practically worthless, and this wealth has been added almost exclusively to the cotton kingdom.

Why the Cottonseed-oil Industry is confined to the South. The cotton seed require very careful treatment. Even the pressure of a large mass of seed when stored in the bulk causes heating and 
fermentation. It is difficult to remove them from the gin, in the present manner of handling them, without crushing many of them. Those damaged soon begin fermenting in the mass, and the whole mass becomes more or less damaged. Rapid handling, therefore, is absolutely necessary. Moreover, the seed are bulky and the cost of transportation very great.

Many attempts have been made, nevertheless, to establish the cottonseed-oil mills in other states. Rhode Island, one of the first states to build the cotton factory, was one of the first states to establish a cottonseed-oil mill. But it was located too far from the cotton fields. Other states outside of the cotton fields have encouraged this industry. Factories have been built and seed have been imported at much expense, but these factories have not prospered like those built near the cotton fields. In I89o Kentucky, New York, Ohio, and Rhode Island contained a few cotton mills, and the value of their products was only about three million dollars. In 1904 Illinois and Virginia contained a few mills and in 1909 Kansas entered the list of states attempting to manufacture cottonseed oil. But in the year last mentioned the total products of the mills beyond the cotton kingdom amounted to one million two hundred fifty thousand dollars, less than half as much as the value of the products in I89o. At the present time there are outside the Southern States fifty cottonseed-oil mills with a total value of fourteen million dollars. 
Other By-products of the Cotton Plant. We have already referred to the cotton stalk and its

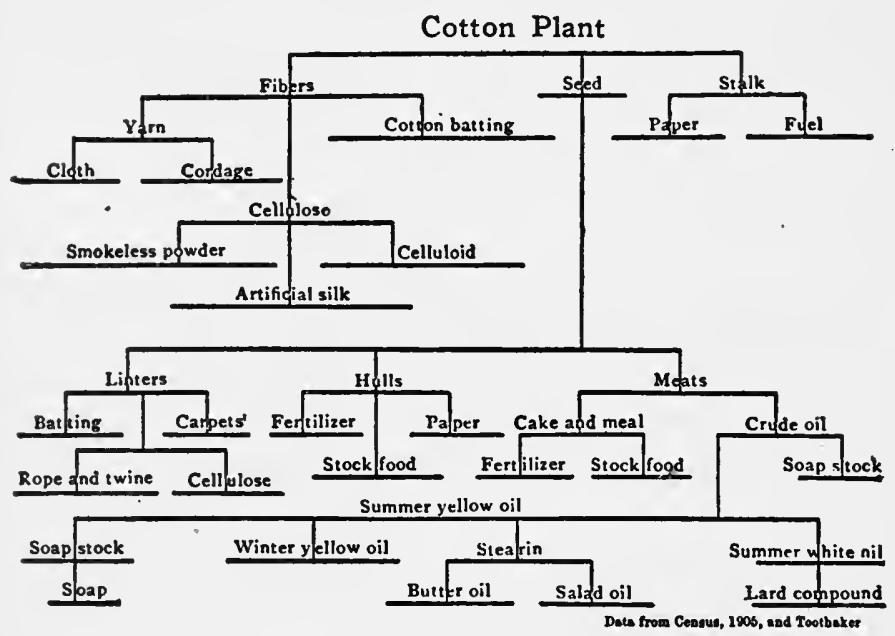

Frcm Commercial Geography by E. V. Roblnson

Industrial uses of the cotton plant.

value as a fertilizer when properly cut up in the fields and worked into the soil. Other uses have also been proposed for it. A machine has been patented which removes from the stalk a valuable. fiber that has been made into bagging for covering bales of cotton. It has also been used for making paper. But, owing to the cost of separating the fiber from the stalk, it has not yet reached a cheap commercial basis. But it has been demonstrated that the fiber may be used in several ways, and that the residue, after the fiber has been removed, may be prepared as a food for stock. The tougher 
portion of the stalk is now being manufactured into umbrella handles.

Thus the intelligence of man and the forces of nature are acting and reacting on each other, while the race is working upward, always passing into higher and clearer intellectual zones, where many phenomena, once mysterious, are made plain, and new forces are brought into service for the advancement of the race. 


\section{BIBLIOGRAPHY}

Agricultural Department: Bureau of Plant Industry. Bulletins Nos. 68, 69, 72, 73, 200.

Experiment Station. Bulletin No. 33 .

Farmers' Bulletins, Nos. 36, 47, 209, 290, 302, $314,344$.

Year Book, 1 907-08-09.

American Fertilizer: January 29, I 9 Io.

Avolett: The Old Plantation.

BAILEY: Principles of Agriculture.

Baines: History of the Cotton Manufacture.

Blue Book Textile Directory: igio-ir.

Burkett and Poe: Cotton.

Burkett, Stevens, and Hill: Agriculture for Beginners.

BUTLER: Education in the United States.

Carpenter: How the World is Clothed.

Chamberlain: How We are Clothed.

Chapman: The Lancashire Cotton Industry.

Cheyney: European Background of American History.

Coman: Industrial History of the United States.

Commerce and Labor: Census Bureau. Bulletins Nos. 10, 107, IIO, III.

CURry: Civil History of the Government of the Confederate States.

Dodd: The Life of Nathaniel Macon.

De Bow: Review.

Duggar: Southern Field Crops.

EARle: Home Life in Colonial Days.

Encyclopedia Britannica.

Fleming: Civil War and Reconstruction in Alabama.

Howe: Memoirs of the Most Eminent American Mechanics.

Hunter: Essentials of Biology.

INGLE: Southern Sidelights.

International Bureau of American Republics: Bulletin, June, rgro. 
James: Practical Agriculture.

Lyon AND Fippin: The Principles of Soil Management.

Martineau: Retrospect of Western Travels.

MASON: The Origins of Invention.

McMaster: History of the People of the United States.

Mississippi Historical Society Publications: Vol. VI.

MonRoe: A Textbook in the History of Education.

Nelson's EnCyclopedia: Everybody's Book of Reference

Olmstead: The Cotton Kingdom.

Political Science Quarterly.

Rhodes: History of the United States, Vols. I, III, IV.

Robinson: Commercial Geography.

Robinson and Beard: The Development of Modern Europe.

Rocheleau: Products of the Soil (in "Great American Industries," Vol. II, 1902-06).

SMEdes: A Southern Planter.

Sмyтн: A Tour in the United States of America.

South Atlantic Quarterly: Vol. IX.

TAussig: The Tariff History of the United States.

TAYLOR: The Modern Factory System.

The South in the Building of the Nation, Vol. V.

Thompson: From the Cotton Field to the Cotton Mill.

THURSTON: Economics and Industrial History.

Tompkins: Cotton Mills Processes and Calculating.

Cotton Mill Commercial Features.

Cotton and Cotton Oil.

TURNER: Rise of the New West.

WEBSTER: A General History of Commerce.

WORLD's WORK: VOl. XXI. 
$-$ 



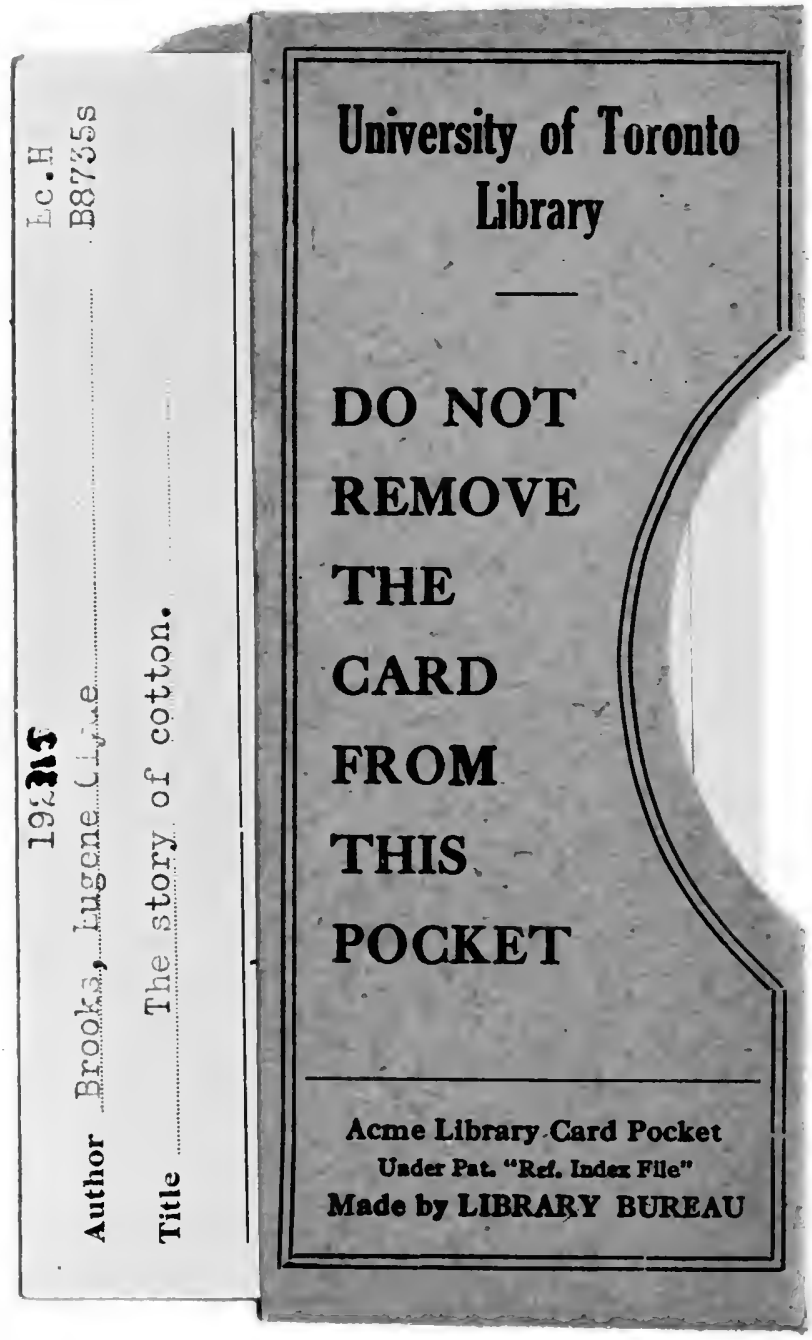


